\title{
Phase I Cultural Resources Investigations at Justiceburg Resevoir on the Double Mountain Fork of the Brazos River, Garza and Kent Counties, Texas Volume II
}

Douglas K. Boyd

Prewitt and Associates, Inc.

Martha Doty Freeman

Prewitt and Associates, Inc.

Michael D. Blum

Prewitt and Associates, Inc.

J. Michael Quigg

Prewitt and Associates, Inc.

Elton R. Prewitt

Prewitt and Associates, Inc.

Follow this and additional works at: https://scholarworks.sfasu.edu/ita

Part of the American Material Culture Commons, Archaeological Anthropology Commons, Environmental Studies Commons, Other American Studies Commons, Other Arts and Humanities Commons, Other History of Art, Architecture, and Archaeology Commons, and the United States History Commons

Tell us how this article helped you.

This Article is brought to you for free and open access by the Center for Regional Heritage Research at SFA ScholarWorks. It has been accepted for inclusion in Index of Texas Archaeology: Open Access Gray Literature from the Lone Star State by an authorized editor of SFA ScholarWorks. For more information, please contact cdsscholarworks@sfasu.edu. 
Phase I Cultural Resources Investigations at Justiceburg Resevoir on the Double Mountain Fork of the Brazos River, Garza and Kent Counties, Texas Volume II

\section{Creative Commons License}

\section{(c) (1) $\Theta$}

This work is licensed under a Creative Commons Attribution-NonCommercial-No Derivative Works 4.0 International License. 
PHASE I CULTURAL RESOURCES INVESTIGATIONS AT JUSTICEBURG RESERVOIR ON THE

DOUBLE MOUNTAIN FORK OF THE BRAZOS RIVER, . GARZA AND KENT COUNTIES, TEXAS

VOLUME II

by

Douglas K. Boyd

Martha Doty Freeman

Michael D. Blum

Elton R. Prewitt

and

J. Michael Quigg

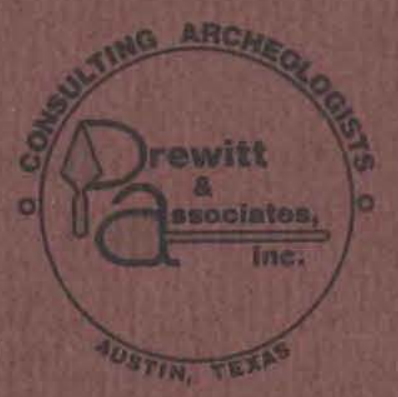

REPORTS OF INVESTIGATIONS, NUMBER 66

TEXAS ANTIQUTTIES COMMITTEE PERMTT NUMBER 603 
PHASE I CULTURAL RESOURCES INVESTIGATIONS AT JUSTICEBURG RESERVOIR ON THE DOUBLE MOUNTAIN FORK OF THE BRAZOS RIVER, GARZA AND KENT COUNTIES, TEXAS

VOLUME II

by

Douglas K. Boyd Martha Doty Freeman Michael D. Blum

Elton R. Prewitt and

J. Michael Quigg

with Contributions by

William A. Bryan

Margaret Ann Howard and

James $W$. Westgate

PRINCIPAL INVESTIGATOR: Elton R. Prewitt

REPORTS OF INVESTIGATIONS NO. 66

Submitted to

City of Lubbock, Lubbock, Texas

by

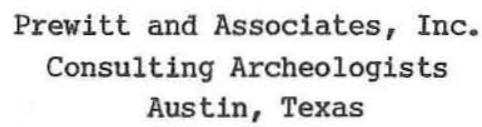

January 1989 
VOLUME I

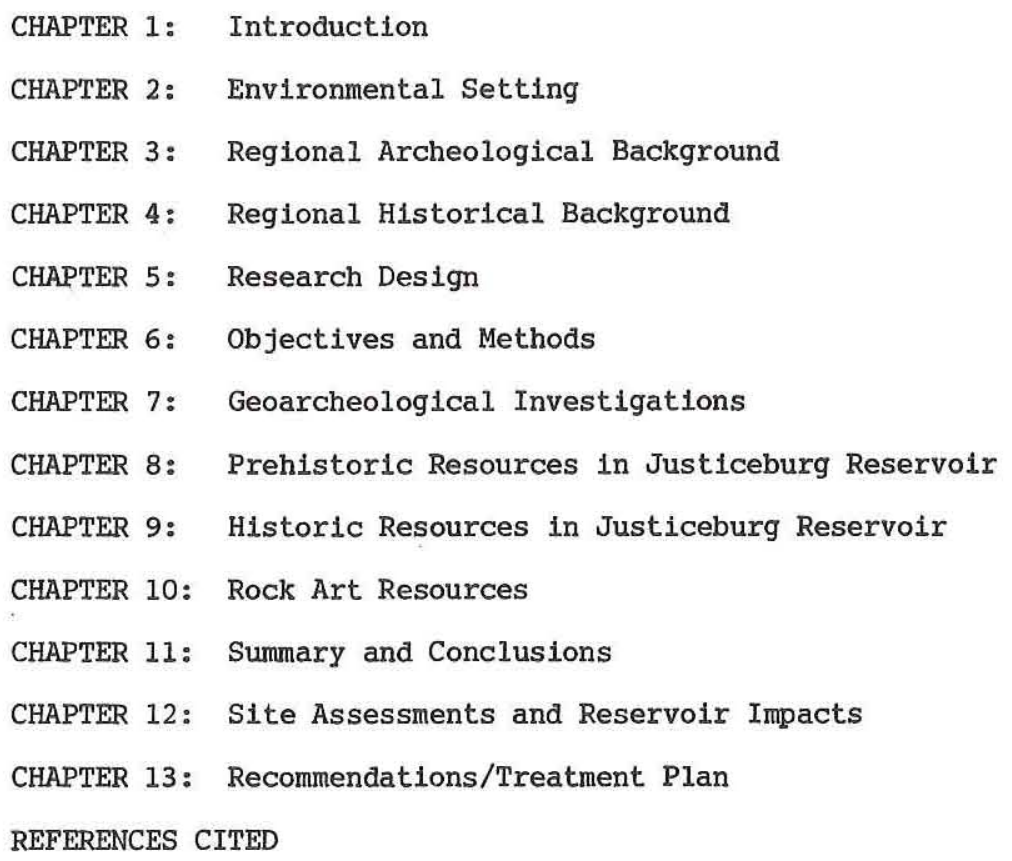

VOLUME II

APPENDIX F: Prehistoric Site Descriptions

APPENDIX G: Historic Site Descriptions

Series Technical Editor: Linda Nance Foster 
TABLE OF CONTENTS

APPENDIX F: PREHISTORIC SITE DESCRIPTIONS

William A. Bryan and Margaret Ann Howard .......... 415

Introduction ....................... . 417

Garza County Sites . . . . . . . . . . . . . . . . 418

Kent County Sites . . . . . . . . . . . . . . . 548

Isolated Finds ........................ 570

References Cited ...................... 575

APPENDIX G: HISTORIC SITE DESCRIPTIONS

William A. Bryan, Martha Doty Freeman,

and Margaret Ann Howard .............. 577

Introduction ..................... 579

Garza County Sites . . . . . . . . . . . . . . 579

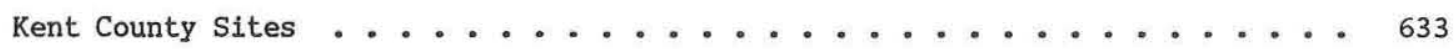

References Clted ..................... 641 

APPENDIX F: Prehistoric Site Descriptions

William A. Bryan

and

Margaret Ann Howard 

INTRODUCTION

The prehistoric site descriptions are divided into three sections: Garza County, Kent County, and Isolated Finds. All sites are described fully in a telegraphic format in order to conserve space. The descriptions are organized by county in alphabetical order and in numerical order of site within each county. Information for each site is organized into six headings: location, description, features, cultural materials observed/collected, shovel test data, and assessment/recommendations. The determination of the percentage of the site remaining intact is based on in-field observations of the postulated original areal extent of the site versus what is still potentially intact. Assessments are based on each site's individual merits and are stated in terms of eligibility for listing on the National Register of Historic Places. These assessments were made by the Project Archeologist and the Principal Investigator based on a site-by-site review. Two categories of eligibility include: potentially eligible (sites with excellent to unknown research potential), and not eligible (sites with little or no further research potential). Research potential is derived from each site's potential to contribute to the resolution of the questions posed in the Research Design (Chapter 5). While most of the research potential categories are reasonably clear, the "unknown" category should be more fully explained. Sites with unknown potential are those that are buried, lack exposed features, and failed to yield temporally or functionally diagnostic materials. The "unknown" designation refers to the inability (based on extant data) to specify which research questions a site may appropriately address rather than a lack of any research potential. Assessments also may refer to exotics. This term is used to identify materials or artifacts that were imported into the local area. Included are such items as obsidian, Alibates agate, Tecovas jasper, and nonlocal ceramics. Recommendations are provided on the basis of each site's assessment. These do not consider the suggested sampling strategy described in Chapter 13, Recommendations/Treatment Plan.

Isolated Finds were thoroughly documented in the field and were assigned trinomial site numbers to facilitate record keeping; however, they are not felt to be worthy of extended descriptions for reporting purposes. Therefore, this category of sites is treated in highly abbreviated form in a separate section following the site descriptions. Information provided for Isolated Finds includes: site number, location, landform, elevation, area, description, and material type. Isolated finds are defined as any single surface artifact or feature with no associated materials or features, or surface sites with a density of cultural materials less than one item in $20 \mathrm{~m}^{2}$. These finds generally are highly disturbed, redeposited, or lack intact context. No shovel testing was done at Isolated Finds, except at sites 41GR411, 41GR482, 41GR519, 41GR532, 41KT46, and 41KT71, where all tests excavated were negative. Only three of these Isolated Finds are dated. These sites are considered to retain little interpretive value beyond the survey level, and none require further work. Because of this, Isolated Finds are not considered eligible for listing on the National Register of Historic Places.

Finally, abbreviations are used throughout the site descriptions. Those referring to roads, distances, elevations, and cardinal directions are self-explanatory. However, two others require explanation. GRC refers to Grand River Consultants, Inc., a firm located in Grand River, Colorado, which performed limited archeological survey at Justiceburg in 1982. NRHP refers to the National Register of Historic Places; this phrase is abbreviated to save space since it must be used in the assessments of each individual site. 
GARZA COUNTY SITES

41GR13

Location: On both sides of FM $2458 \mathrm{ca} .1 .2 \mathrm{~km} \mathrm{E}$ of intersection with U.S. Highway 84 , and $0.4 \mathrm{~km} \mathrm{E}$ of the FM 2458 crossing at Salt Branch.

Description: Lithic procurement area/open campsite on upland margin near mouth of Salt Branch; elevation 2240-2260 ft msl. First recorded by Emmett Shedd in 1976. Features ("fire hearths"); stone tools such as knives, manos, awls; arrow points; prehistoric ceramics; and debitage were noted. Revisited in 1982 by GRC, who noted similar materials. Current investigations added an historic component and extended the site north across FM 2458; it occupies a much larger area $\left(300,000 \mathrm{~m}^{2}\right)$ than previously reported. All of the features and the densest part of the lithic scatter are south of FM 2458. This is also the most disturbed area; disturbances consist of old and new FM 2458. The northern portion is much less disturbed (a small area adjacent to the modern road has been bladed) and contains more cultural materials. While no features were found on the surface, there is a good possibility for buried features. The site appears to be a repeatedly used camping area, with plant processing and lithic procurement activities also represented. Components noted are late Archalc-Late Prehistoric and Historic (see Appendix G for description of historic component).

Features: Four burned rock features noted. Feature 1 is a ca. 70-cm-diameter cluster of lithic debitage and burned Potter chert cobbles. Feature 2 is a ca. 60-cm-diameter cluster of lithic debitage and burned Potter chert cobbles. Feature 3 consists of a ca. 70-cm-diameter loose cluster of burned sandstone and Potter chert cobbles with no debitage. Feature 4 is a ca. 70-cm-diameter cluster of burned sandstone and Potter chert cobbles containing lithic debitage and a battered mano.

Cultural Materials Observed/Collected: Cores, tested cobbles, modifled flakes, and debitage of Potter chert and coarse-grained quartzite; modified and tertiary flakes of Edwards chert; manos; hammerstones; dart point fragments; and obsidian flakes and fragments. Ten items collected (see Appendices A and B).

Shovel Test Data: Two shovel tests excavated. One was negative; the other contained flakes to $20 \mathrm{~cm}$ below surface.

Assessment/Recommendations: Over 50\% of prehistoric component appears intact; it contains subsurface materials, features, and exotics. Prehistoric component has excellent research potential and is judged to be potentially eligible for listing on NRHP. Recommend controlled collection, mapping, and testing.

$\underline{41 G R 31}$

Location: Ca. $2.9 \mathrm{~km} \mathrm{NNW}$ of U.S. Highway 84 bridge at Sand Creek, and $2.4 \mathrm{~km}$ ESE of U.S. Highway 84 bridge at Double Mountain Fork. 
Description: Open campsite on bedrock terrace overlooking floodplain of Double Mountain Fork; elevation 2240-2260 ft msl, area 19,800 $\mathrm{m}^{2}$. Originally recorded by Emmett Shedd in 1958 who reported boat-shaped mortar holes in sandstone bedrock. In 1982, GRC revisited the site, confirmed the presence of mortar holes, and noted stone tools such as manos, hammerstones, and bifaces; debitage; and concentrations of utilized mussel shell fragments. Damage by relic hunters was observed. Current investigations found 15 mortar holes in the sandstone bedrock and an artifact scatter. Site is a campsite where plant processing was the main activity. No temporal components identified; undefined Prehistoric.

Features: Fifteen pointed-oval bedrock mortar holes which range in size from $38 \mathrm{~cm}$ long, $20 \mathrm{~cm}$ wide, and $30.5 \mathrm{~cm}$ deep to $26.5 \mathrm{~cm}$ long, $10 \mathrm{~cm}$ wide, and $10 \mathrm{~cm}$ deep (Kirkpatrick 1978:33; site GA11).

Cultural Materials Observed/Collected: Sandstone manos and metates, debitage (cores, primary flakes, and thinning flakes) of Potter chert, red coarse-grained quartzite, and local chert gravels. No collections made.

Shovel Test Data: One shovel test excavated; two fence staples at 0-40 $\mathrm{cm}$ below surface and possible ground sandstone slab at $60-80 \mathrm{~cm}$ below surface.

Assessment/Recommendations: Over $50 \%$ of site appears intact; it contains subsurface materials and features. Site has good research potential and is judged to be potentially eligible for listing on NRHP. Recommend mapping and testing.

$\underline{41 G R 33}$

Location: North bank of Double Mountain Fork, ca. $2.8 \mathrm{~km}$ ESE of intersection of U.S. Highway 84 and FM 2458, and $1.9 \mathrm{~km}$ ENE of U.S. Highway 84 bridge at Double Mountain Fork.

Description: Lithic procurement area/open campsite on the upland margin in eroding area along canyon rim of Double Mountain Fork; elevation 2240-2260 ft msl, area $225,000 \mathrm{~m}^{2}$. Originally recorded by Emmett Shedd in 1958 who reported prehistoric ceramics. Revisited in 1982 by GRC, who recorded it as two separate sites, both lithic scatters containing debitage of Potter chert, red coarse-grained quartzite, local chert gravels, and stone tools.

Current investigations discovered that sites recorded by GRC and Shedd are part of single larger site. Numerous burned rock features observed. Artifact scatter concentrated in three areas, each $100 \mathrm{~m}$ long and $50 \mathrm{~m}$ wide. Two in drainage areas contain most of the burned rocks; third on top of a small point is a knapping station. Site is camping and lithic procurement area. Evidence of plant processing is mortar holes and abundant grinding stones. Archaic, Late Prehistoric, and Historic components (see Appendix G for description of historic component).

Features: Many clusters (ranging from ca. 150 to ca. $50 \mathrm{~cm}$ in diameter) of burned sandstone fragments. Knapping station (ca. $100 \times 100 \mathrm{~m}$ ) has concentration of Edwards and Potter chert debitage with choppers, hammerstones, and scrapers. Two bedrock mortars -one ca. $28 \mathrm{~cm}$ long, $12 \mathrm{~cm}$ wide, and $17 \mathrm{~cm}$ deep; other ca. $24 \mathrm{~cm}$ long, $14 \mathrm{~cm}$ wide, and $6 \mathrm{~cm}$ deep. 
Cultural Materials Observed/Collected: Livermore arrow point, manos and mano fragments, metate fragments, choppers, scrapers, debitage, and scatter of isolated burned Potter chert fragments. GRC also noted a drill, dart point, and gouge. Six items collected (see Appendices A and B).

Shovel Test Data: One shovel test excavated; debitage to $60 \mathrm{~cm}$ below surface.

Assessment/Recommendations: Over 90\% of prehistoric component appears intact; it contains subsurface deposits and features. Prehistoric component has excellent research potential and is judged to be potentially eligible for listing on NRHP. Recommend controlled collection, mapping, and testing.

\section{GR51 (Dorward Ranch Site)}

Location: Ca. $0.3 \mathrm{~km}$ ESE of confluence of Double Mountain Fork and Rocky Creek, and $2.1 \mathrm{~km}$ SSW of confluence of Double Mountain Fork and Cat Hollow.

Description: Rock art site on vertical sandstone face on bluffs overlooking head of a small drainage flowing into Double Mountain Fork; elevation 2200-2220 ft msl, area $2000 \mathrm{~m}^{2}$. First recorded by Aaron Riggs in 1965. Site contains petroglyphs depicting nine wagons led by palrs of horned animals (oxen), and triangles. Petroglyphs also depict houses or similar structures (Riggs 1965:11-12). Petroglyphs are partly destroyed by more-recent historic names, dates, and drawings. Site later revisited by Emmett Shedd. Current investigations noted additional elements: human figures depicting Indians and Europeans, horses, shaman, geometric flgures, and historic inscriptions. No other indication of cultural activity in vicinity of site. The rock art is being obliterated by vandalism. Any cultural materials may have been collected by sightseers. Aboriginal rock art dates to Historic contact period (see Appendix G for description of historic component).

Features: Petroglyphs (see Fig. 41) in two areas. First is large vertical sandstone face ca. $15 \mathrm{~m}$ wide and $8 \mathrm{~m}$ tall covered with petroglyphs; second is under sandstone ledge with one petroglyph depicting an eye.

Cultural Materials Observed/Collected: None.

Shovel Test Data: None.

Assessement/Recommendations: Over 50\% of the aboriginal rock art appears intact. This aspect of site has excellent research potential and is judged to be potentially eligible for listing on NRHP. Recommend detalled recording (see Table 37).

\section{GR54 (Reed Shelter)}

Location: Ca. 2.4 km NNW of confluence of Double Mountain Fork and Rocky Creek, and $2.0 \mathrm{~km}$ WNW of confluence of Double Mountain Fork and Cat Hollow. 
Description: Rockshelter with aboriginal and historic rock art eroded out of sandstone bedrock near base of bluff above Gobbler Creek; elevation $2240 \mathrm{ft} \mathrm{msl}$, area $450 \mathrm{~m}^{2}$. First recorded and entirely excavated in 1966 by Aaron Riggs and South Plains Archeological Soclety. Riggs (1966:48, 54) reported petroglyphs, subsurface deposits, and bedrock mortars. Revisited in 1982 by GRC, who discovered historic graffiti on bluff face. Current investigations found sparse cultural materials in alluvial deposits on terrace below shelter. Components represented are Late Prehistoric and Historic (see Appendix G for description of historic component).

Features: Two petroglyph panels (see Fig. 35a-b). One has deerlike animals; other has human figure, three parallel lines, and a wavy line (Riggs 1966:48). Five small basinshaped bedrock mortar holes (possibly natural features).

Cultural Materials Observed/Collected: Previous investigators noted Harrell, Garza, and Fresno arrow points, untyped dart point, knife, scrapers, manos, metate, and debitage including one obsidian flake. One item was collected in current investigations (see Appendices $\mathrm{A}$ and $\mathrm{B})$.

Shovel Test Data: One shovel test yielded debitage at 40-60 cm below surface.

Assessment/Recommendations: Rockshelter deposits have been removed, cultural deposits in alluvial terrace less than $50 \%$ intact; both have low research potential and are judged to be not eligible for listing on NRHP. Aboriginal rock art over $90 \%$ intact; has excellent research potential and is judged to be potentially eligible for listing on NRHP. Recommend no further work in rockshelter and terrace deposits but detailed recording of rock art (see Table 37).

41GR203

Location: Ca. $3.2 \mathrm{~km} \mathrm{SE}$ of intersection of U.S. Highway 84 and FM 2458, and $2.6 \mathrm{~km} \mathrm{NW}$ of confluence of Sand Creek and Double Mountain Fork.

Description: Open campsite on eroding upland ridge and erosional remnant bench above Double Mountain Fork; elevation 2240-2280 ft msl, area 11,200 $\mathrm{m}^{2}$. First recorded by Shedd in 1977, who reported arrow points, dart points, burned rock features ("fire hearths"), tools, and debitage. Shedd noted disturbance from erosion, plowing, and surface collection. Current investigations found one burned rock feature and scatter of lithics with no diagnostic artifacts. Also noted disturbance from dirt road and an historic occupation. Site is campsite with plant processing evident. Components are Archaic-Late Prehistoric/ Historic (see Appendix G for description of historic component).

Features: One burned rock concentration ca. $80 \mathrm{~cm}$ in diameter.

Cultural Materials Observed/Collected: Burned sandstone cobbles, ground sandstone fragment, small biface fragment of Edwards chert, utilized flake of local chert, and debitage of local chert and Potter chert. No collection made.

Shovel Test Data: None; thin soils. 
Assessment/Recommendations: Less than 50\% of prehistoric component remains intact; limited features, no subsurface deposits. Prehistoric component has no research potential and is judged to be not eligible for listing on NRHP. No further work recommended.

\section{$41 \mathrm{GR} 204$}

Location: Ca. $2.3 \mathrm{~km}$ NNW of confluence of Double Mountain Fork and Rocky Creek, and $1.9 \mathrm{~km} \mathrm{~W}$ of confluence of Double Mountain Fork and Cat Hollow.

Description: Lithic procurement area/open campsite on lower alluvial terrace in an area dissected by two small drainages above Gobbler Creek; elevation $2230 \mathrm{ft} \mathrm{msl}$, area $10,000 \mathrm{~m}^{2}$. First recorded by Shedd in 1977, who reported dart points, burned rock features, and chipped and ground stone tools and debitage. Shedd also noted damage from erosion and a pipeline. Current investigations found site much larger than Shedd described and noted deep soils. Site is a campsite with evidence of lithic procurement. Component noted is undefined Archaic.

Features: Two burned sandstone features; one ca. $1 \mathrm{~m}$ diameter contains 10-12 cobbles In moderately dense cluster, other ca. $50 \mathrm{~cm}$ diameter contains 5 cobbles.

Cultural Materlals Observed/Collected: Two manos, chopper of Potter chert, burned sandstone, and debitage of Potter chert, Edwards chert, and coarse-grained quartzite. Single flake of Tecovas jasper; Shedd reported jasper dart points, hammerstones, and scrapers. Fourteen items collected (see Appendices A and B).

Shovel Test Data: One shovel test excavated contained abundant debitage to $60 \mathrm{~cm}$ below surface.

Assessment/Recommendations: Over 50\% of site appears intact; it contains subsurface deposits, features, and exotics. Site has excellent research potential and is judged to be potentially eligible for listing on NRHP. Recommend mapping and testing.

\section{GR205}

Location: Ca. $2.0 \mathrm{~km}$ NNW of confluence of Double Mountain Fork and Rocky Creek, and $2.1 \mathrm{~km}$ WSW of confluence of Double Mountain Fork and Little Grape Creek.

Description: Open campsite on edge of upland margin above Gobbler Creek; elevation $2250 \mathrm{ft} \mathrm{msl}$, area $2400 \mathrm{~m}^{2}$. First reported by Emmett Shedd. Current investigations found three mortar holes in a large sandstone boulder and lithic scatter. Site has been visited by collectors and is eroded and deflated. Site is a camp with evidence of plant processing. No temporal components identified, undefined Prehistoric.

Features: Two pointed-oval mortar holes ranging from $18 \mathrm{~cm}$ long, $7 \mathrm{~cm}$ wide, and $6 \mathrm{~cm}$ deep to $45 \mathrm{~cm}$ long, $25 \mathrm{~cm}$ wide, and $37 \mathrm{~cm}$ deep, and a shallow basin mortar hole. 
Cultural Materials Observed/Collected: Burned fragments of Potter chert and flakes of red coarse-grained quartzite and Edwards chert. One item collected (see Appendices A and B).

Shovel Test Data: One shovel test excavated contained flake at 0-20 cm below surface.

Assessment/Recommendations: Over 50\% of site appears intact; it contains subsurface deposits and features. Site has moderate research potential and is judged to be potentially eligible for listing on NRHP. Recommend mapping and testing.

\section{GR206}

Location: Ca. $2.3 \mathrm{~km}$ NNE of confluence of Double Mountain Fork and Rocky Creek, and $3.4 \mathrm{~km}$ WNW of confluence of Double Mountain Fork and Little Grape Creek.

Description: Lithic procurement area/open campsite on small rise on upper alluvial terrace above Double Mountain Fork north of Cat Hollow; elevation $2230 \mathrm{ft}$ msl, area 10,000 $\mathrm{m}^{2}$. First recorded by Shedd in 1977, who reported prehistoric ceramics, arrow and dart points, two burned rock features, manos, hammerstones, bifaces, scrapers, and scatter of debitage. Revisited in 1982 by GRC. Current investigations relocated burned rock features but observed few tools and no ceramics. Site is a small campsite with some evidence of lithic procurement. Components are late Archaic to Late Prehistoric.

Features: Two burned rock features. One ca. $1.5 \times 1.0 \mathrm{~m}$ of burned sandstone cobbles and flakes; second $30 \mathrm{~cm}$ in diameter of burned sandstone cobbles and a utilized flake. Two features are disturbed and may be one feature.

Cultural Materials Observed/Collected: Tested cobbles and flakes of Potter chert, flakes of Edwards chert and coarse-grained quartzite. Nine items collected (see Appendices $A$ and $B)$.

Shovel Test Data: One shovel test excavated; debitage to $40 \mathrm{~cm}$ below surface. Burned sandstone concentration at ca. $30 \mathrm{~cm}$ below surface.

Assessment/Recommendations: Over $90 \%$ of site appears intact; it contains subsurface deposits and features. Site has excellent research potential and is judged to be potentially eligible for listing on NRHP. Recommend mapping and testing.

41GR207

Location: Ca. $0.5 \mathrm{~km}$ NNW of confluence of Double Mountain Fork and Cat Hollow, and $2.5 \mathrm{~km}$ NNE of confluence of Double Mountain Fork and Rocky Creek, at upper end of Cat Hollow.

Description: Open campsite on a ridge in the upland margin flanked by Cat Hollow and a small drainage; elevation 2240-2300 ft msl, area 16,000 $\mathrm{m}^{2}$. Erosion has formed a series of benches with small remnant knolls on them. The area is quite eroded, and a great deal 
of exposed bedrock is present at the lower edge of the site. First recorded by Shedd in 1977, who reported dart points, burned rock features, and a scatter of chipped stone tools and debitage. Current investigations found features and lithic scatter but no tools or diagnostic artifacts. Component noted is undefined Archaic.

Features: Three burned sandstone features, all less than $1 \mathrm{~m}$ in diameter; one also contains debitage.

Cultural Materials Observed/Collected: Gouge; flakes and modified flakes of Potter chert, Edwards chert, coarse-grained quartzite, and local chert gravels, including a few Potter chert cobbles. Two items collected (see Appendices A and B).

Shovel Test Data: One negative shovel test found soils to $25 \mathrm{~cm}$.

Assessment/Recommendations: Over $75 \%$ of site appears intact; it contains features but is surficial. Site has good research potential and is judged to be potentially eligible for listing on NRHP. Recommend mapping and testing.

\section{GR238}

Location: Ca. $1.8 \mathrm{~km}$ SSW of intersection of Garza/Kent county line and Double Mountain Fork, and $1.6 \mathrm{~km} \mathrm{NE}$ of confluence of Double Mountain Fork and Little Grape Creek.

Description: Rock art site on near-vertical exposure of sandstone caprock just below edge of canyon rim near mouth of Grape Creek; elevation $2250 \mathrm{ft} \mathrm{msl}$, area less than $1 \mathrm{~m}^{2}$. Single panel of aboriginal rock art (see Fig. 35c); lines lightly engraved, so petroglyph may be Late Prehistoric, but no temporal components were identified.

Features: Panel measuring $50 \mathrm{~cm}$ wide and $55 \mathrm{~cm}$ tall; single petroglyph depicting cat with large bushy tail or other animal mounted on back of "cat" figure.

Cultural Materials Observed/Collected: None.

Shovel Test Data: None; no soils.

Assessment/Recommendations: Over $90 \%$ of site appears intact; it contains no subsurface deposits. Site has excellent research potential and is judged to be potentially eligible for listing on NRHP. Recommend detailed recording (see Table 37).

\section{GR239}

Location: Ca. $0.9 \mathrm{~km}$ W of confluence of Double Mountain Fork and Cat Hollow, and 1.9 km N of confluence of Double Mountain Fork and Rocky Creek; on Cedar Hill.

Description: Lithic procurement area/open campsite on upland hill overlooking eroded terrace area; elevation 2260-2330 ft msl, area 135,000 $\mathrm{m}^{2}$. First recorded by Dr. Robert Campbell of Texas Tech University. Rerecorded in 1982 by GRC, who reported burned rock 
feature, lithic scatter, and single hammerstone. Current investigations relocated burned rock feature and artifact scatter. Site is in natural outcrop of Potter chert and coarsegrained quartzite. Some disturbance by recent oilfield activity (including surface collection) and county road which runs through center of site. Camping and lithic procurement are indicated. No temporal components identified; undefined Prehistoric.

Features: One cluster of fire-cracked Potter chert fragments within larger concentration of burned sandstone and Potter chert fragments; possible dump for used boiling stones.

Cultural Materials Observed/Collected: Tested cobbles, cores, flakes, fragments of Potter chert and coarse-grained quartzite, and a few flakes of Edwards chert. Scrapers and choppers of Potter chert, and sandstone mano. One item collected (see Appendices A and B).

Shovel Test Data: One negative shovel test found shallow soils.

Assessment/Recommendations: Over $75 \%$ of site appears intact; deposits are surficial but include feature. Site has moderate research potential and is judged to be potentially eligible for listing on NRHP. Recommend mapping and testing.

\section{$\underline{41 \mathrm{GR} 240}$}

Location: Ca. $6.1 \mathrm{~km}$ SSW of confluence of Double Mountain Fork and South Sage Creek, and $0.6 \mathrm{~km}$ ESE of confluence of Double Mountain Fork and Rocky Creek.

Description: Open campsite in bedrock basin in small side canyon of Grape Creek just. below upland margin; elevation $2255 \mathrm{ft} \mathrm{msl}$, area $1200 \mathrm{~m}^{2}$. Light scatter of stone tools, burned rocks, and chipped stone debris; one burned rock concentration. No temporal components identified; undefined Prehistoric.

Features: One $2 \times 4-m$ concentration of burned Potter chert fragments.

Cultural Materials Observed/Collected: Mano, scrapers, 1ithic debitage, and isolated burned rocks. Six items collected (see Appendices A and B).

Shovel Test Data: One shovel test; lithic debitage to $20 \mathrm{~cm}$ below the surface, soil depth ca. $25 \mathrm{~cm}$.

Assessment/Recommendations: Over $90 \%$ of site appears intact; it contains subsurface deposits and features. Site has unknown research potential and is judged to be potentially eligible for listing on NRHP. Recommend mapping and testing.

\section{GR243}

Location: Ca. $3.3 \mathrm{~km}$ WNW of confluence of Double Mountain Fork and Little Grape Creek, and $0.4 \mathrm{~km} \mathrm{NNE}$ of confluence of Double Mountain Fork and Rocky Creek. 
Description: Lithic procurement area/open campsite on ridge and two benches within upland margin, overlooking small drainage to east and Double Mountain Fork to south; elevation 2220-2280 ft msl, area 20,000 $\mathrm{m}^{2}$. First recorded by Robert Campbell between 1974 and 1977. Rerecorded in 1982 by GRC, who reported a scatter of stone tools and chipped stone debitage and "minimum" features.

Current investigations found lithic scatter considerably larger than reported by GRC, and several small burned rock features. Features and scatter of lithics concentrated into three separate areas; concentration of scattered burned sandstone fragments and chipped stone debitage on upland ridge measures $\mathrm{ca} .40 \times 15 \mathrm{~m}$. Other two concentration areas contain greatest concentration of cultural materials and all burned rock features. Concentration on higher bench is $10 \mathrm{~m}$ in dlameter and contains burned sandstone fragments, manos, debitage, and several small burned rock clusters. Concentration on lower bench is ca. $15 \times 10 \mathrm{~m}$ and consists of scatter of coarse-grained quartzite choppers and debitage and few burned rock clusters. Site may be extension of $41 \mathrm{GR} 291$, an open campsite located ca. $75 \mathrm{~m}$ to the east. No temporal components Identified; undefined Prehistoric.

Features: Numerous hearths of burned sandstone cobbles and fragments, all less than 1 $\mathrm{m}$ in diameter.

Cultural Materials Observed/Collected: Three manos; hammerstones; bifaces (choppers) of coarse-grained quartzite; cores, flakes, and angular fragments of Potter chert; flakes and fragmented cobbles of coarse-grained quartzite; and thinning flakes of Edwards chert. Single Tecovas jasper flake. GRC noted scraper and retouched flakes of quartzite and a burin of Edwards chert. One item collected (see Appendices A and B).

Shovel Test Data: Two shovel tests, both negative, found soil depth of $70 \mathrm{~cm}$ on top of ridge and shallow solls on bench below ridge.

Assessment/Recommendations: Over $90 \%$ of site is intact; it contains features and exotics. Site has good research potential and is judged to be potentially eligible for listing on NRHP. Recommend mapping and testing.

\section{$41 \mathrm{GR} 246$}

Location: Ca. $0.3 \mathrm{~km}$ SSW of confluence of Double Mountain Fork and Little Grape Creek, and $3.3 \mathrm{~km} \mathrm{E}$ of confluence of Double Mountain Fork and Cat Hollow.

Description: Open campsite eroding from cutbank of erosional gully in gently sloping valley wall on west side of Little Grape Creek; elevation $2170 \mathrm{ft} \mathrm{ms} 1$, area $600 \mathrm{~m}^{2}$. Two burned rock features and scattered burned rocks. No other artifacts encountered. Site is severely eroded. Camping or food preparation represented. No temporal components identifled; undefined Prehistoric.

Features: Two hearths, both ca. $1.5 \mathrm{~m}$ in diameter; one composed of burned sandstone slabs and cobbles, and the second composed of burned sandstone cobbles.

Cultural Materials Observed/Collected: Two burned sandstone fragments. No collections made. 
Shovel Test Data: One negative shovel test found soil depth of at least $70 \mathrm{~cm}$.

Assessment/Recommendations: Less than $25 \%$ of site appears intact; no subsurface deposits. Site has no research potential and is judged to be not eligible for listing on NRHP. No further work recommended.

\section{$\underline{41 G R 249}$}

Location: Ca. $3.9 \mathrm{~km} \mathrm{~S}$ of confluence of Double Mountain Fork and Grape Creek, and 6.5 $\mathrm{km} \mathrm{E}$ of confluence of Double Mountain Fork and Rocky Creek.

Description: Faunal locality in cutbank of a narrow alluvial terrace overlooking Grape Creek; elevation $2210 \mathrm{ft} \mathrm{msl}$, area $1 \mathrm{~m}^{2}$. Disarticulated bison bones are right and left mandible, metapodial, and unidentified long bone. No temporal components identified; undefined Prehistoric.

Features: Ca. 120-cm-long cluster of bison bones at ca. 65-90 cm below surface.

Cultural Materials Observed/Collected: None.

Shovel Test Data: None; no artifacts in soil removed to expose feature.

Assessment/Recommendations: Integrity of site unknown; subsurface deposits present. Site has good research potential and is judged to be potentially eligible for listing on NRHP. Recommend mapping and testing.

\section{GR250}

Location: Ca. $0.8 \mathrm{~km}$ NNW of confluence of Double Mountain Fork and Salt Branch, and $1.3 \mathrm{~km}$ ENE of intersection of U.S. Highway 84 and FM 2458.

Description: Lithic procurement area/open campsite on large ridge on eroded upper alluvial terrace above Salt Branch; elevation 2240-2260 ft msl, area 75,000 $\mathrm{m}^{2}$. Large Potter chert cobbles and Quaternary gravels exposed on surface. Site has artifact scatter of tools, debitage, and burned rock features. Majority of artifacts found on top of ridge; historic component located on lower end of ridge (see Appendix G for description of historic component). Features indicative of camping; lithic procurement probable. Temporal components identified are undefined Prehistoric and Historic.

Features: Two burned Potter chert concentrations ca. 7-10 $\mathrm{m}$ in diameter could be boiling stone dumps or middens dispersed by erosion and deflation. The large burned Potter chert scatter, ca. 30-40 m long and ca. $15 \mathrm{~m}$ wide, may have been several smaller clusters eroded into large scatter or severely eroded large burned rock midden.

Cultural Materials Observed/Collected: Hammerstones, three manos, biface, core tool, chopper of Potter chert, and chipped stone debris of Potter chert, local chert, and red coarse-grained quartzite. Seventeen items collected (see Appendices A and B). 
Shovel Test Data: Two shovel tests excavated; one within the prehistorlc component was positive. Cultural materials to $40 \mathrm{~cm}$ below surface and soil depth of $80 \mathrm{~cm}$.

Assessment/Recommendations: Over 90\% of prehistoric component appears intact; it contains subsurface deposits and features. Prehistoric component has good research potential and is judged to be potentially eligible for listing on NRHP. Recomend controlled collection, mapping, and testing.

\section{$\underline{41 G R 251}$}

Location: Ca. $1.6 \mathrm{~km} \mathrm{NE}$ of intersection of U.S. Highway 84 and FM 2458 , and $1.1 \mathrm{~km}$ NNW of confluence of Double Mountain Fork and Salt Branch.

Description: Lithic procurement area on eroding alluvial terrace above Salt Branch; elevation 2240-2270 ft $\mathrm{msl}$, area $24,500 \mathrm{~m}^{2}$. Three outcrops of Potter chert, local chert, and coarse-grained quartzite contain tested cobbles, burned cobbles, and a biface fragment (preform). Lithic procurement indicated, with some lithic reduction. No temporal components identified; undefined Prehistoric.

Features: None.

Cultural Materials Observed/Collected: Distal biface fragment of red medium-grained quartzite; tested cobbles of Potter chert, local chert, and coarse-grained guartzite; and a few burned Potter chert cobbles. One item collected (see Appendices A and B).

Shovel Test Data: One shovel test excavated; flake at $20-40 \mathrm{~cm}$ below surface.

Assessment/Recommendations: Over 90\% of site appears intact; it contains subsurface deposits. Site has good research potential and is judged to be potentially eligible for listing on NRHP. Recommend controlled surface collection, mapping, and testing.

\section{$\underline{41 G R 253}$}

Location: Ca. $1.5 \mathrm{~km} \mathrm{NE}$ of intersection of U.S. Highway 84 and FM 2458 , and $1.0 \mathrm{~km}$ NNE of confluence of Double Mountain Fork and Salt Branch.

Description: Open campsite on erosional remnant of high alluvial terrace forming small rise in floodplain of Salt Branch; elevation $2250 \mathrm{ft} \mathrm{msl}$, area $3000 \mathrm{~m}^{2}$. Artifact and burned rock scatter with two features. Disturbed by brush clearing and burning, and occasional flooding of Salt Branch. Camping area with no temporal components identified; undefined Prehistoric.

Features: Two features: burned rock concentration and cluster of large cobbles. Burned rock concentration ca. $3 \mathrm{~m}$ in diameter consists of burned sandstone fragments, burned Potter chert cobbles, and one flake. Represents either hearth with Potter chert boiling stones or remains of heat-treatment of lithic raw materials. Cobble cluster ca. 1 $\mathrm{m}$ in diameter includes several large cobble manuports, cores, and flakes; represents knapping station or cache. 
Cultural Materials Observed/Collected: Large, crude, unifacially worked flake (scraper); cores and burned cobbles of Potter chert; flakes of local chert and red coarsegrained quartzite; and burned sandstone fragments. No collections made.

Shovel Test Data: Two negative shovel tests found sandy loam to ca. $30 \mathrm{~cm}$ below surface.

Assessment/Recommendations: Over $75 \%$ of site appears intact; it contains features. Site has moderate research potential and is judged to be potentlally eligible for listing on NRHP. Recommend controlled collection and mapping.

\section{GR254}

Location: Ca. $1.5 \mathrm{~km} \mathrm{NE}$ of intersection of U.S. Highway 84 and FM 2458 , and $0.7 \mathrm{~km} \mathrm{~N}$ of confluence of Double Mountain Fork and Salt Branch.

Description: This open campsite is situated on a slight rise within the lower alluvial terrace of Salt Branch; elevation $2230 \mathrm{ft} \mathrm{msl}$, area $816 \mathrm{~m}^{2}$. Artifact scatter of ground stone tools, chipped stone debitage, burned rocks, and chert cobble manuports. Site disturbed by flood erosion and possibly brush-clearing. Ground stone tools indicate camping. No temporal components identified; undefined Prehistoric.

Features: None.

Cultural Materials Observed/Collected: Quartzite mano, sandstone metate fragment, Potter chert core, local chert flake, several burned cobbles of Potter chert and sandstone, and several unmodified Potter chert cobble manuports. No collections made.

Shovel Test Data: Two negative shovel tests found loam to $3 \mathrm{~cm}$ over clay.

Assessment/Recommendations: Over $75 \%$ of site appears intact. Site has moderate research potential and is judged to be potentially eligible for listing on NRHP. Recommend controlled collection and mapping.

\section{GR255}

Location: Ca. $4.5 \mathrm{~km}$ SW of intersection of Garza/Kent county line and Double Mountain Fork, and $4.0 \mathrm{~km}$ ENE of confluence of Double Mountain Fork and Rocky Creek.

Description: Lithic procurement area on upper edge of canyon overlooking Grape Creek; elevation $2250 \mathrm{ft} \mathrm{msl}$, area $6750 \mathrm{~m}^{2}$. Artifact scatter most dense in northern part of site; may represent knapping station and lithic procurement area. No temporal components identified; undefined Prehistoric.

Features: None. 
Cultural Materlals Observed/Collected: Tested cobbles and debitage of Potter chert, local chert, and coarse-grained quartzite; burned sandstone. Two items collected (see Appendices $\mathrm{A}$ and $\mathrm{B}$ ).

Shovel Test Data: One shovel test excavated; debitage to ca. $30-40 \mathrm{~cm}$ below surface and soil depth of ca. $50 \mathrm{~cm}$.

Assessment/Recommendations: Over $90 \%$ of site appears intact; it contains subsurface deposits. Site has good research potential and is judged to be potentially eligible for listing on NRHP. Recommend mapping and testing.

\section{GR256}

Location: Ca. $3.7 \mathrm{~km} \mathrm{E}$ of confluence of Double Mountain Fork and Rocky Creek, and 2.2 $\mathrm{km}$ SSW of confluence of Double Mountain Fork and Little Grape Creek.

Description: Open campsite in an eroded bedrock basin on side canyon of Grape Creek; elevation $2250 \mathrm{ft} \mathrm{msl}$, area $16,500 \mathrm{~m}^{2}$. Sparse scatter of lithic artifacts and burned rocks in eroded areas. Artifacts indicative of camping; component noted is late Archaic/Late Prehistoric.

Features: None.

Cultural Materials Observed/Collected: Deadman's arrow point; Mahomet dart point; biface; chipped stone cores, tested cobbles, and debitage of Potter chert and local chert; and burned rock fragments. Three items collected (see Appendices A and B).

Shovel Test Data: One negative shovel test found less than $20 \mathrm{~cm}$ of soil.

Assessment/Recommendations: Over $75 \%$ of site appears intact; it contains no subsurface deposits. Site has unknown research potentlal but is judged to be potentially eligible for listing on NRHP. Recommend controlled collection and mapping.

\section{GR258}

Location: $\mathrm{Ca} .3 .1 \mathrm{~km} \mathrm{~S}$ of confluence of Double Mountain Fork and Little Grape Creek, and $4.5 \mathrm{~km}$ ESE of confluence of Double Mountain Fork and Rocky Creek.

Description: Open campsite on low bedrock terrace overlooking Little Grape Creek; elevation 2240-2270 ft msl, area 45,000 $\mathrm{m}^{2}$. Burned rock feature, bedrock mortar, and scatter of lithic artifacts and burned rocks in eroded areas. No temporal components Identified; undefined Prehistoric.

Features: Cluster of burned sandstone cobbles and fragments and debitage. Bedrock mortar in center of cluster is ca. $32 \mathrm{~cm}$ long, $13 \mathrm{~cm}$ wide, and $11 \mathrm{~cm}$ deep. 
Cultural Materials Observed/Collected: Mano, scraper, flakes and pebble cores of local chert and red coarse-grained quartzite, and burned sandstone fragments. Five items collected (see Appendices A and B).

Shovel Test Data: Two shovel tests excavated; one negative. Positive test near burned rock cluster yielded debitage to $30 \mathrm{~cm}$ below surface. Negative test indicated soil depth of ca. $60 \mathrm{~cm}$ at southwestern end of site.

Assessment/Recommendations: Over $75 \%$ of site appears intact; it contains subsurface deposits and features. Site has good research potential and is judged to be potentially eligible for listing on NRH. Recommend controlled collection, mapping, and testing.

\section{GR259}

Location: Ca. $0.6 \mathrm{~km}$ WNW of confluence of Double Mountain Fork and Grape Creek, and $2.2 \mathrm{~km} \mathrm{NNE}$ of confluence of Double Mountain Fork and Little Grape Creek.

Description: Lithic procurement area on upland margin overlooking Double Mountain Fork; elevation 2260-2270 ft msl, area $3125 \mathrm{~m}^{2}$. Sparse scatter of tested cobbles and burned Potter chert fragments. Damaged by dirt road and oilfield core test pad near northern edge of site. No temporal components identified; undefined Prehistoric.

Features: None.

Cultural Materials Observed/Collected: Tested cobbles of Potter chert, local chert, and red coarse-grained quartzite, and burned Potter chert fragments. No collections made.

Shovel Test Data: One negative shovel test found soll depth of ca. $40 \mathrm{~cm}$.

Assessment/Recommendations: Over $90 \%$ of site appears intact, but it contains no subsurface deposits. Site has low research potential and is judged to be not eligible for listing on NRHP. No further work recommended.

\section{GR260}

Location: Ca. $3.0 \mathrm{~km}$ SW of intersection of Garza/Kent county line and Double Mountain Fork, and $0.8 \mathrm{~km} \mathrm{NNW}$ of Double Mountain Fork and Little Grape Creek.

Description: Lithic procurement area/open campsite on bluff at head of small side canyon opening into Double Mountain Fork; elevation 2240-2250 ft msl, area $7500 \mathrm{~m}^{2}$. Scatter of lithics and burned sandstone corresponding with an outcrop of Quaternary gravels. Burned rocks may indicate camping. No temporal components identified; undefined Prehistoric.

Features: None. 
Cultural Materials Observed/Collected: Tested cobbles and flakes of Potter chert, local chert, and coarse-grained quartzite, and burned sandstone fragments. No collections made.

Shovel Test Data: One negative shovel test found soll depth of ca. $10 \mathrm{~cm}$.

Assessment/Recommendations: Over $90 \%$ of site appears intact; it lacks subsurface deposits. Site has no research potential and is judged to be not eligible for listing on NRHP. No further work recommended.

\section{GR261}

Location: Ca. $3.0 \mathrm{~km}$ SW of intersection of Garza/Kent county line and Double Mountain Fork, and $0.4 \mathrm{~km}$ NNW of confluence of Double Mountain Fork and Little Grape Creek.

Description: Lithic procurement area on edge of bluff overlooking Double Mountain Fork; elevation 2230-2250 ft $\mathrm{msl}$, area $35,000 \mathrm{~m}^{2}$. Lithic scatter in a natural outcrop of Quaternary gravels. No definite features except cluster of possibly burned sandstone cobbles and area of burned Potter chert fragments. Site is somewhat eroded. No temporal components identified; undefined Prehistoric.

Features: None.

Cultural Materials Observed/Collected: Tested cobbles of Potter chert, red coarsegrained quartzite, and local chert; and burned fragments of Potter chert. No collections made.

Shovel Test Data: One negative shovel test found soil depth of ca. $45 \mathrm{~cm}$.

Assessment/Recommendations: Over $75 \%$ of site appears intact; it lacks subsurface deposits. Site has good research potential and is judged to be potentially eligible for listing on NRHP. Recommend mapping and testing.

\section{$\underline{41 G R 262}$}

Location: Ca. $3.3 \mathrm{~km}$ SW of intersection of Garza/Kent county line and Double Mountain Fork, and $0.5 \mathrm{~km} \mathrm{NW}$ of confluence of Double Mountain Fork and Little Grape Creek.

Description: Lithic procurement area on prominent ridge on upland margin overlooking Double Mountain Fork; elevation 2170-2240 ft msl, area $8000 \mathrm{~m}^{2}$. Lithic scatter near outcrop of Potter chert cobbles. Southwestern area of site contains cores and flakes, while southeastern area contains tested and unmodified cobbles. No temporal components identified; undefined Prehistoric.

Features: None. 
Cultural Materials Observed/Collected: Edwards chert biface, quartzite biface, cores and flakes of Potter chert, and flakes of local chert and red coarse-grained quartzite. One item collected (see Appendices A and B).

Shovel Test Data: One negative shovel test found a soll depth of $\mathrm{ca} .40 \mathrm{~cm}$.

Assessment/Recommendations: Over $50 \%$ of site appears intact; it lacks subsurface deposits. Site has good research potential and is judged to be potentially eligible for listing on NRHP. Recommend controlled collection and mapping.

\section{GR263}

Location: Ca. $2.2 \mathrm{~km}$ NW of confluence of Double Mountain Fork and Little Grape Creek, and $2.0 \mathrm{~km}$ NE of confluence of Double Mountain Fork and Cat Hollow.

Description: Lithic procurement area/open campsite on upland ridge overlooking confluence of two small unnamed drainages east of Cat Hollow; elevation 2250-2270 ft msl, area $128,000 \mathrm{~m}^{2}$. First reported by Robert Campbell. Recorded by GRC in 1982 along with 41GR264, as one site; GRC reported scatter of ground and chipped stone tools and lithic debris, including a projectile point preform. Current investigations found site to cover much larger area than stated by GRC and to include an historic component. Site consists of a large, dense artifact scatter and numerous burned rock features eroding out of eolian deposits. Features include burned rock clusters, burned rock concentrations, and burned rock and lithic concentrations. Most cultural materials found in central and northwestern areas of site. Extensive evidence of previous surface collecting and some erosion. Temporal components are late Archaic, Late Prehistoric, and Historic (see Appendix G for description of historic component.

Features: Seventeen features identified at site: 3 burned rock concentrations, 6 burned rock concentrations with tools and debitage, and 8 burned rock clusters. Two burned rock concentrations have burned sandstone and Potter chert; one has only burned Potter chert. These diffuse rock scatters are ca. 4-5 m in diameter. Six burned rock concentrations include tools and chipped stone debitage and range from ca. 3 to 10 m diameter. Burned rocks are both sandstone and Potter chert. Chipped stone includes flakes of Potter chert, coarse-grained quartzite, and Edwards chert; and two scrapers.

Eight burned rock clusters ranging from 40 to $200 \mathrm{~cm}$ in diameter are dense scatters of burned sandstone cobbles and fragments, with some fragments of burned Potter chert. Debitage and tools included in most clusters. One unusual burned rock cluster has sandstone fragments in a $40-\mathrm{cm}$-diameter circle with fragmented Potter chert cobble in the center, topped by burned sandstone slab. Feature could be "dutch oven" or grill for baking.

Cultural Materials Observed/Collected: Five manos, two choppers, eight bifaces, four scrapers, Clear Fork gouge, dart point fragment, dart point, and arrow point. Abundant chipped stone debitage (mostly flakes) of Potter chert, Edwards chert, and coarse-grained quartzite. Forty-nine items collected (see Appendices A and B).

Shovel Test Data: Two shovel tests yielded cultural materials to $40 \mathrm{~cm}$ below surface including arrow point at $\mathrm{ca} .15 \mathrm{~cm}$ and found soll depth of ca. 60-80 cm. 
Assessment/Recommendations: Despite vandalism, over $75 \%$ of prehistoric component appears intact; it contains subsurface deposits and abundant features. Prehistoric component has excellent research potential and is judged to be potentially eligible for listing on NRHP. Recommend controlled collection, mapping, and testing.

\section{$\underline{41 G R 264}$}

Location: Ca. $2.5 \mathrm{~km}$ SW of confluence of Double Mountain Fork and Little Grape Creek, and $2.5 \mathrm{~km}$ NE of confluence of Double Mountain Fork and Cat Hollow.

Description: Open campsite above unnamed drainage east of Cat Hollow on hill on east edge of 41GR263; elevation 2220-2265 ft msl, area 25,000 $\mathrm{m}^{2}$. First reported by Robert Campbell between 1974 and 1975; recorded by GRC in 1982 along with 41GR263 (see above); GRC noted bedrock mortar holes, rock piles, and burned rock and lithic scatter. Current investigations found similar artifact scatter and features. Extensive evidence of surface collection and rodent activity. Site was habitation or campsite; no evidence of lithic procurement. Temporal component noted is middle Archaic.

Features: Fifteen features identified: five burned rock clusters, five burned rock concentrations, probable burned rock midden, two bedrock mortars, and two rock features. Five burned rock clusters composed of burned sandstone fragments and measuring ca. $1 \mathrm{~m}$ diameter include debitage and three tools (mano, hammerstone, and scraper). Five burned rock concentrations composed of burned sandstone fragments, debitage, and chipped and ground stone tools. Two larger and less deflated concentrations contain small concentrations or clusters of burned sandstone. Possible buried burned rock midden exposed in backdirt of gopher burrow has dark gray, ashy soll with fragments of burned sandstone. Two pointed-oval mortars found in a sandstone bedrock ledge; one is about $25 \mathrm{~cm} 10 n g, 15 \mathrm{~cm}$ wide, and $28 \mathrm{~cm}$ deep, while other is about $36 \mathrm{~cm}$ long, $21 \mathrm{~cm}$ wide, and $17 \mathrm{~cm}$ deep.

One of two rock piles is a ca. $2 \times 1-m$ stack of small sandstone boulders on bedrock ledge at head of small drainage. Boulders were removed from center of the pile; shovel test in the soil underneath yielded flakes and contacted limestone bedrock at ca. $20 \mathrm{~cm}$. No evidence of human osteological remains, so it may not be cairn burial. Second rock feature is ca. $60 \times 65 \times 70-\mathrm{cm}$ pile of small sandstone boulders on slope of ridge overlooking creek; not investigated.

Cultural Materials Observed/Collected: Two hammerstones, three scrapers, two manos, core of Tecovas jasper, biface, untyped stemmed dart point; debitage mostly Edwards chert, with some Potter chert and coarse-grained quartzite. Bone fragments and mussel shells also present. Fifty-three items collected (see Appendices A and B).

Shovel Test Data: Two shovel tests excavated; both positive. One near largest burned rock scatter in area of darker soil yielded cultural materials to ca. $40 \mathrm{~cm}$ and soil depth of ca. $60 \mathrm{~cm}$. Second test in rock feature described above.

Assessment/Recommendations: Over $75 \%$ of site appears intact; it contains subsurface deposits, features, and exotics. Site has excellent research potential and is judged to be potentially eligible for listing on NRHP. Recommend controlled collection, mapping, and testing. 


\section{$\underline{41 G R 265}$}

Location: Ca. $3.3 \mathrm{~km}$ SW of intersection of Garza/Kent county line and Double Mountain Fork, and $0.6 \mathrm{~km}$ NW of confluence of Double Mountain Fork and Little Grape Creek.

Description: Lithic procurement area on edge of bluff overlooking Double Mountain Fork; elevation $2265 \mathrm{ft} \mathrm{msl}$, area $1500 \mathrm{~m}^{3}$. First reported by Campbell in 1975 . Sparse lithic scatter in outcrop of Quaternary gravels. No temporal components identified; undefined Prehistoric.

Features: None.

Cultural Materials Observed/Collected: Tested cobbles and flakes of Potter chert and red coarse-grained quartzite, biface. No collections made.

Shovel Test Data: One negative shovel test indicated soil depth of ca. $40 \mathrm{~cm}$.

Assessment/Recommendations: Over $90 \%$ of site appears intact; no subsurface deposits. Site has good research potential and is judged to be potentially eligible for listing on NRHP. Recommend controlled collection and mapping.

\section{$\underline{41 G R 266}$}

Location: Ca. $3.2 \mathrm{~km}$ SW of intersection of Garza/Kent county line and Double Mountain Fork, and $0.9 \mathrm{~km} \mathrm{NW}$ of confluence of Double Mountain Fork and Little Grape Creek.

Description: Lithic procurement area on deflated ridge on bluff overlooking Double Mountain Fork; elevation 2240-2260 ft msl, area 22,000 $\mathrm{m}^{2}$. Very sparse lithic scatter in deflated Quaternary gravel outcrop. Minimally used lithic procurement area. No temporal components identified; undefined Prehistoric.

Features: None.

Cultural Materials Observed/Collected: Tested cobbles and flakes of Potter chert, local chert, and coarse-grained quartzite. No collections made.

Shovel Test Data: One negative shovel test found soil depth of ca. $35 \mathrm{~cm}$.

Assessment/Recommendations: Over $50 \%$ of site appears intact; it lacks subsurface deposits. Site has low research potential and is judged to be not eligible for listing on NRHP. No further work recommended.

\section{$\underline{41 G R 267}$}

Location: Ca. $3.1 \mathrm{~km}$ SW of intersection of Garza/Kent county line and Double Mountain Fork, and $1.2 \mathrm{~km}$ NNW of confluence of Double Mountain Fork and Little Grape Creek. 
Description: Lithic procurement area on east rim of small canyon opening into Double Mountain Fork; elevation 2240-2270 ft msl, area $375,000 \mathrm{~m}^{2}$. Scatter of chipped stone debitage and burned rocks, with burned Potter chert scatter on north end of site which may represent heat-treatment of raw lithic materials. Western edge of site is eroded, while east side made have deep soils. No temporal components identified; undefined Prehistoric.

Features: None.

Cultural Materials Observed/Collected: Tested cobbles and flakes of local Ogallala chert, Potter chert (burned and unburned), and red coarse-grained quartzite; few flakes of Edwards chert, one retouched. No collections made.

Shovel Test Data: One negative shovel test indicated soil depth of ca. $15 \mathrm{~cm}$.

Assessment/Recommendations: Over $75 \%$ of site appears intact; it lacks subsurface deposits. Site has good research potential and is judged to be potentially eligible for listing on NRHP. Recommend controlled collection, mapping, and testing.

\section{$41 \mathrm{GR} 268$}

Location: Ca. $3.2 \mathrm{~km}$ WSW of intersection of Garza/Kent county line and Double Mountain Fork, and $1.4 \mathrm{~km}$ NW of confluence of Double Mountain Fork and Little Grape Creek.

Description: Lithic procurement area/open campsite on ridge between two drainages which flow into Double Mountain Fork; elevation 2240-2260 ft msl, area 39,950 m² Moderately dense scatter of tested cobbles and chlpped stone debitage with several concentrations of burned rocks and lithic materials. Lithic procurement main activity represented, with some camping. No temporal components identified; undefined Prehistoric.

Features: Three concentrations of burned sandstone and lithic debitage, ranging in size from $10 \times 7$ to $45 \times 15 \mathrm{~m}$.

Cultural Materials Observed/Collected: Retouched flakes of Edwards chert, tested cobbles and chipped stone debitage of Potter chert and a small amount of Edwards chert, and burned sandstone fragments. No collections made.

Shovel Test Data: Two negative shovel tests found soil depth of ca. $60 \mathrm{~cm}$.

Assessment/Recommendations: Over $75 \%$ of site appears intact; has features but lacks subsurface deposits. Site has moderate research potential and is judged to be potentially eligible for listing on NRHP. Recommend mapping and testing.

\section{$\underline{41 G R 269}$}

Location: Ca. $3.3 \mathrm{~km}$ SW of intersection of Garza/Kent county line and Double Mountain Fork, and $1.7 \mathrm{~km} \mathrm{NW}$ of confluence of Double Mountain Fork and Little Grape Creek. 
Description: Lithic procurement area/open campsite on upland margin at head of a small side canyon near spring; elevation 2250-2260 ft msl, area $3750 \mathrm{~m}^{2}$. Sparse scatter of lithic artifacts with burned rock scatters and bedrock mortar. Evidence of disturbance from brush clearing and pipeline cutting through north end of site. Plant processing, camping, and limited lithic procurement took place on site. No temporal components identified; undefined Prehistoric.

Features: Burned rock scatters comprised of burned sandstone, tested cobbles, and chipped stone debitage; they are ca. $4 \mathrm{~m}$ in diameter, $5 \mathrm{~m}$ apart, and may be one feature disturbed by brush clearing. Pointed-oval bedrock mortar is ca. $40 \mathrm{~cm}$ long, $13 \mathrm{~cm}$ wide, and $26 \mathrm{~cm}$ deep, with ca. $11 \mathrm{~cm}$ of $\mathrm{fill}$ in bottom.

Cultural Materials Observed/Collected: Tested cobbles and flakes of Potter chert, flakes of Edwards chert, red coarse-grained quartzite, and local chert; thumbnail scraper. Two items collected (see Appendices A and B).

Shovel Test Data: One shovel test excavated; positive, with burned rocks to ca. $20 \mathrm{~cm}$ and soil depth of ca. $50 \mathrm{~cm}$.

Assessment/Recommendations: Over $75 \%$ of site appears intact; it contains subsurface deposits and features. Site has moderate research potential and is judged to be potentially eligible for listing on NRHP. Recommend mapping and testing.

\section{GR270}

Location: Ca. $3.2 \mathrm{~km}$ SSE of confluence of Double Mountain Fork and Grape Creek, and $2.7 \mathrm{~km} \mathrm{SE}$ of confluence of Double Mountain Fork and Little Grape Creek.

Description: Faunal locality in erosional gully in alluvial terrace on west bank of Grape Creek; elevation $2200 \mathrm{ft} \mathrm{msl}$, area $100 \mathrm{~m}^{2}$. Disarticulated bison bones exposed in cutbank ca. $2 \mathrm{~m}$ below the ground surface over area ca. $5 \mathrm{~m} \mathrm{long}$ and ca. $1 \mathrm{~m} \mathrm{high.} \mathrm{No}$ evidence of cultural activity. Bones include ribs, a scapula, and long bones; appear to represent one animal. May be a bison kill or a natural death. No temporal components identified; undefined Prehistoric.

Features: None.

Cultural Materials Observed/Collected: None.

Shovel Test Data: Exposure in cutbank made shovel testing unnecessary.

Assessment/Recommendations: Integrity of site is unknown; it contains subsurface materials. Site has good research potential and is judged to be potentially eligible for listing on NRHP. Recommend mapping and testing.

\section{GR271}

Location: Ca. $3.9 \mathrm{~km}$ WSW of intersection of Garza/Kent county line and Double Mountain Fork, and $2.2 \mathrm{~km} \mathrm{NW}$ of confluence of Double Mountain Fork and Little Grape Creek. 
Description: Lithic procurement area/open campsite on upper edge of canyon rim overlooking side canyon opening into Double Mountain Fork; elevation 2240-2270 ft msl, area $23,400 \mathrm{~m}^{2}$. Lithic scatter with rock piles or calrns and two burned rock clusters. Site has been surface collected by pothunters. Other disturbances include brush clearing and pipeline running through south end of site. Camping is major activity indicated, with some lithic procurement. Temporal component identified is Late Prehistoric.

Features: Six rock piles on edge of site overlooking canyon, comprised of recently broken and moved sandstone slabs. Four piles sit on soil, while two others sit on exposed bedrock. These features could be recent or prehistoric features disturbed in recent times. Two burned sandstone clusters; one ca. $1 \mathrm{~m}$ in diameter may be hearth. other hearth is somewhat smaller and is located within $60 \times 50-m$ scatter of burned rocks, tool fragments, and chipped stone debitage.

Cultural Materials Observed/Collected: Untyped arrow point fragment with serrated edges; scraper of local chert; two fragments of ground sandstone; tested cobbles and chipped stone debris of Potter chert, Edwards chert, red coarse-grained quartzite, and local chert; and burned Potter chert cobbles. Two items collected (see Appendices A and B).

Shovel Test Data: Two shovel tests excavated; one positive. Test in rock pile was negative, even though it was troweled and screened through 1/16-inch-mesh, but feature continues deeper than $27 \mathrm{~cm}$ below surface. Shovel test near scatter was positive, with flake at ca. $5 \mathrm{~cm}$ and soil depth of ca. $40 \mathrm{~cm}$.

Assessment/Recommendations: Over 50\% of site appears intact; it contains features and subsurface deposits. Site has good research potential and is judged to be potentially eligible for listing on NRHP. Recommend mapping and testing.

\section{GR272}

Location: $\mathrm{Ca} .3 .7 \mathrm{~km}$ WSW of intersection of Garza/Kent county line and Double Mountain Fork, and $2.3 \mathrm{~km}$ NW of confluence of Double Mountain Fork and Little Grape Creek.

Description: Lithic procurement area/open campsite extends from upper rim of side canyon to floodplain at bottom of canyon on an unnamed drainage east of Cat Hollow; elevation of 2180-2260 ft msl, area $125,000 \mathrm{~m}^{2}$. Site mainly on upland margin; materials on slopes probably washed down from above. Scattex of chipped and ground stone tools, tested cobbles, chipped stone debris, and burned Potter chert fragments with concentrations of burned rocks, tested cobbles, and chipped stone debitage. Surface of site seems to be covered by eolian sand deposits which are in the process of eroding. Evidence of surface collection by pothunters; some erosion. No temporal components identified; undefined Prehistoric.

Features: Concentrations of burned sandstone, with some burned Potter chert and lithic materials in the areas of small drainages.

Cultural Materials Observed/Collected: Potter chert scraper; mano of red coarsegrained quartzite; gouge; crude biface of Potter chert; tested cobbles and debitage of Potter chert, coarse-grained quartzite, and local chert; and burned cobbles and fragments of sandstone and Potter chert. No collections made. 
Shovel Test Data: Two negative shovel tests in bench areas below canyon rim found soil depth of $\mathrm{ca} .25 \mathrm{~cm}$.

Assessment/Recommendations: Over $75 \%$ of site appears intact; it may contain features but lacks subsurface deposits. Site has moderate research potential and is judged to be potentially eligible for listing on NRHP. Recommend mapping and testing.

\section{GR273}

Location: Ca. $4.2 \mathrm{~km}$ WSW of intersection of Garza/Kent county line and Double Mountain Fork, and $2.4 \mathrm{~km}$ NW of confluence of Double Mountain Fork and Little Grape Creek.

Description: Lithic procurement area/open campsite on upper part of canyon rim and in erosional areas on lower rim overlooking an unnamed drainage east of Cat Hollow; elevation 2230-2250 ft msl, area $7500 \mathrm{~m}^{2}$. Scatter of burned rocks, tested cobbles, and chipped stone debitage with two clusters of burned rocks. Scatter of historic artifacts within larger prehistoric scatter. Disturbance by old pasture road, buried pipeline, and brush clearing. Probable camping and lithic procurement activities at site. Temporal components are undefined Prehistoric and Historic (see Appendix G for description of historic component).

Features: Two 1-m-diameter deflated burned rock clusters containing debitage and fragments of burned sandstone.

Cultural Materials Observed/Collected: Tested and burned cobbles of Potter chert and chipped stone debitage of local chert and red coarse-grained quartzite. No collections made.

Shovel Test Data: One negative shovel test found soil depth of ca. $50 \mathrm{~cm}$.

Assessment/Recommendations: Over $90 \%$ of prehistoric component is intact; it contains features but lacks subsurface deposits. Prehistoric component has no research potential and is judged to be not eligible for listing on NRHP. No further work recommended.

\section{GR274}

Location: Ca. $4.4 \mathrm{~km}$ SW of intersection of Garza/Kent county line and Double Mountain Fork, and $1.0 \mathrm{~km} \mathrm{~W}$ of confluence of Double Mountain Fork and Little Grape Creek.

Description: Lithic procurement area/open campsite on gently sloping valley wall on erosional remnant and several promontories overlooking Double Mountain Fork; elevation 2220-2300 ft msl, area 78,750 $\mathrm{m}^{2}$. Scatter of burned rocks, tested cobbles, chipped stone debitage, and projectile point with several concentrations of burned rocks and chipped stone debitage. More chipped stone debris on higher slopes, and more burned rocks on lower, flatter areas. Lithic procurement in higher areas and camping in lower areas. Lower area of site also has eolian sand deposits. Temporal component identified is late Archaic.

Features: None. 
Cultural Materials Observed/Collected: Untyped corner-notched dart point (resembles Ensor) of Edwards chert; tested cobbles, cores, and flakes of Potter chert, red coarsegrained quartzite, and local chert; and fragments of burned sandstone. One item collected (see Appendices A and B).

Shovel Test Data: One negative shovel test found soll depth of ca. $30 \mathrm{~cm}$.

Assessment/Recommendations: Over $75 \%$ of site appears intact; it may lack subsurface deposits. Site has unknown research potential and is judged to be potentially eligible for listing on NRHP. Recommend mapping and testing.

\section{GR275}

Location: Ca. $3.2 \mathrm{~km} \mathrm{NE}$ of confluence of Double Mountain Fork and Rocky Creek, and $1.8 \mathrm{~km}$ ESE of confluence of Double Mountain Fork and Cat Hollow.

Description: Lithic procurement area/open campsite on upland point and erosional remnant overlooking a small side canyon running into the Double Mountain Fork; elevation 2260-2305 ft msl, area $21,600 \mathrm{~m}^{2}$. Lithic scatter with four areas of concentration ranging from ca. $7 \times 20$ to $20 \times 30 \mathrm{~m}$ and burned rock feature. Thin eolian sands cover site. Suspect that site has been surface collected. Both camping and lithic procurement activities are represented. No temporal components identified; undefined Prehistoric.

Features: Cluster ( $1 \mathrm{~m}$ diameter) of burned sandstone cobbles and fragments.

Cultural Materials Observed/Collected: Biface of local chert; tested cobbles and debitage of Potter chert, local chert, and red coarse-grained quartzite; and fragments of burned sandstone and Potter chert. One item collected (see Appendices A and B).

Shovel Test Data: One negative shovel test found soil depth of ca. $30 \mathrm{~cm}$.

Assessment/Recommendations: Over $90 \%$ of site appears intact; it may lack subsurface deposits but has features. Site has moderate research potential and is judged to be potentially eligible for listing on NRHP. Recommend mapping and testing.

\section{GR276}

Location: Ca. $4.7 \mathrm{~km}$ SW of intersection of Garza/Kent county line and Double Mountain Fork, and $1.6 \mathrm{~km}$ WSW of confluence of Double Mountain Fork and Little Grape Creek.

Description: Lithic procurement area/open campsite on rim of side canyon opening into Double Mountain Fork; elevation 2280-2305 ft msl, area 12,000 $\mathrm{m}^{2}$. Lithic scatter in eroded area of exposed gravels. Burned rocks indicate limited camping. No temporal components identified; undefined Prehistoric.

Features: None. 
Cultural Materials Observed/Collected: Debitage of Potter chert, local chert, and red coarse-grained quartzite; and burned sandstone. No collections made.

Shovel Test Data: None.

Assessment/Recommendations: Over $90 \%$ of site appears intact; it lacks subsurface deposits. Site has no research potential and is judged to be not eligible for listing on NRHP. No further work recommended.

$\underline{41 G R 277}$

Location: Ca. $4.9 \mathrm{~km}$ SW of intersection of Garza/Kent county Iine and Double Mountain Fork, and $1.8 \mathrm{~km}$ WSW of confluence of Double Mountain Fork and Little Grape Creek.

Description: Open campsite in bottom of drainage area at confluence of two small creeks; elevation 2230-2250 ft msl, area $13,000 \mathrm{~m}^{2}$. Burned rock clusters and 11thic scatter. Considerable damage from surface collection and digging; some erosion. Deep sand could contain buried cultural deposits. Camp area with food processing as a major activity. No temporal components identified; undefined Prehistoric.

Features: Five small burned sandstone clusters.

Cultural Materials Observed/Collected: Potter chert chopper and scraper; two sandstone manos; quartzite mano; worked flakes and debitage of Potter chert, Edwards chert, Tecovas jasper, Alibates agate, local chert, and red coarse-grained quartzite; and fragments of burned sandstone. Thirteen items collected (see Appendices A and B).

Shovel Test Data: Three shovel tests excavated; one positive. Cultural materials to $40 \mathrm{~cm}$ below the surface; soil depth of ca. $40 \mathrm{~cm}$ in western part of site, ca. $80 \mathrm{~cm} \mathrm{in}$ central part, and ca. $25 \mathrm{~cm}$ in northern part.

Assessment/Recommendations: Over $75 \%$ of site appears intact; it contains subsurface deposits, features, and exotics. Site has excellent research potential and is judged to be potentially eligible for listing on NRHP. Recommend controlled collection, mapping, and testing.

\section{$\underline{41 G R 280}$}

Location: Ca. $2.5 \mathrm{~km} \mathrm{NE}$ of confluence of Double Mountain Fork and Rocky Creek, and $2.7 \mathrm{~km}$ WSW of confluence of Double Mountain Fork and Little Grape Creek.

Description: Lithic procurement area on top of bluff overlooking Double Mountain Fork floodplain; elevation 2220-2240 ft msl, area 15,000 $\mathrm{m}^{2}$. Sparse 1ithic scatter in outcrop of Quaternary gravels exposed by erosion. No temporal components identified; undefined Prehistoric.

Features: None. 
Cultural Materials Observed/Collected: Tested cobbles, cores, and debitage of Potter chert, local chert, and red and gray coarse-grained quartzite. No collections made.

Shovel Test Data: None.

Assessment/Recommendations: Over $90 \%$ of site appears intact; it lacks subsurface deposits. Site has good research potential and is judged to be potentially eligible for listing on NRHP. Recommend mapping and testing.

\section{GR281}

Location: $\mathrm{Ca} .0 .4 \mathrm{~km} \mathrm{E}$ of confluence of Double Mountain Fork and Cat Hollow, and 2.4 $\mathrm{km}$ NNE of confluence of Double Mountain Fork and Rocky Creek.

Description: Small lithic procurement area in drainage within alluvial terrace overlooking Double Mountain Fork; elevation $2190 \mathrm{ft} \mathrm{msl,} \mathrm{area} 600 \mathrm{~m}^{2}$. Area exploited to minimal extent. No temporal components identified; undefined Prehistoric.

Features: None.

Cultural Materials Observed/Collected: Tested cobbles, primary flakes, and secondary flakes of Potter chert and red coarse-grained quartzite; burned fragments of same materials. No collections made.

Shovel Test Data: None.

Assessment/Recommendations: Over $90 \%$ of site appears intact; it lacks subsurface deposits. Site has low research potentlal and is judged to be not eligible for listing on NRHP. No further work recommended.

\section{GR282 (Ward Petroglyph Site)}

Location: Ca. $2.8 \mathrm{~km} \mathrm{NE}$ of confluence of Double Mountain Fork and Rocky Creek, and $2.7 \mathrm{~km}$ WNW of confluence of Double Mountain Fork and Little Grape Creek.

Description: Rock art site in overhang shelter on bluff slope overlooking Double Mountain Fork; elevation $2220 \mathrm{ft} \mathrm{msl,} \mathrm{area} 30 \mathrm{~m}^{2}$. Shelter area ca. $3 \mathrm{~m} \mathrm{high,} 10 \mathrm{~m} \mathrm{long}$, and $2.5 \mathrm{~m}$ deep with bedrock floor. Several panels of rock art (see Figs. 43 and 44 ) in $3 \times 7-\mathrm{m}$ area. No evidence of occupation. Dated to Historic Aboriginal period due to depiction of horses.

Features: Four petroglyph panels. First measures ca. $120 \mathrm{~cm}$ long and $100 \mathrm{~cm}$ tall, depicts 2 horses (one drawn behind the other), 10 human figures, and series of 17 parallel vertical tally marks $5 \mathrm{~cm}$ tall and $20 \mathrm{~cm}$ long. Most human figures have rectangular bodies, with two stick flgures. Arms and legs depicted with single lines, and heads as circles. One figure wears a breechcloth; another wears a robe. Latter figure and two others drawn with arms bent upward at elbows and fingers at ends of arms. 
Second panel below and to right of first measures ca. $50 \mathrm{~cm}$ long and $30 \mathrm{~cm}$ tall; contains geometric figures, human figures, human riding horse, and zoomorphic figure tentatively identified as a cat. Geometric figures are rectangles with vertical line through the center or cruciform. Two standing human figures, one wearing robe and holding staff or spear. Arms and legs depicted by single lines, head by circle. Horseback rider poorly defined, but horse shown in detall with bent legs, ears, and decorated bridle. Two other figures too indistinct to interpret.

Third panel $115 \mathrm{~cm}$ long and $40 \mathrm{~cm}$ tall depicts two deer with long necks and short, straight horns. Additional marks cannot be interpreted.

Fourth panel $5 \mathrm{~cm}$ wide and $40 \mathrm{~cm}$ tall has simple oval outline with a $10-\mathrm{cm}-$ long line extending downward from lower end.

Cultural Materials Observed/Collected: None.

Shovel Test Data: None.

Assessement/Recommendations: Over $75 \%$ of site appears intact; it lacks subsurface deposits. Site has excellent research potential and is judged to be potentially eligible for listing on NRHP. Recommend detailed recording (see Table 37).

\section{$\underline{41 \mathrm{GR} 286}$}

Location: Ca. $2.9 \mathrm{~km}$ NNW of confluence of Double Mountain Fork and Rocky Creek, and $2.6 \mathrm{~km}$ WNW of confluence of Double Mountain Fork and Little Grape Creek.

Description: Lithic procurement area/open campsite on two ridges separated by drainage on upper edge of canyon rim overlooking Double Mountain Fork; elevation 2240-2270 ft msl; area $50,000 \mathrm{~m}^{2}$. Lithic scatter and 12 burned rock clusters on ridges. Burned rock features concentrated on eastern edge of site. Camping area used repeatedly, with some I1thic procurement. No temporal components 1dentified; undefined Prehistoric.

Features: Twelve features: 8 clusters of burned Potter chert cobbles and fragments and 4 clusters of burned sandstone. Burned sandstone clusters only on eastern edge of site and probably are hearths. Clusters of burned Potter chert may have been used as boiling stones.

Cultural Materlals Observed/Collected: Potter chert chopper; quartzite mano; and tested cobbles, cores, and flakes of Potter chert and red coarse-grained quartzite. No collections made.

Shovel Test Data: One negative shovel test found soil depth of ca. $50 \mathrm{~cm}$.

Assessment/Recommendations: Over $90 \%$ of site appears intact; it contains features but lacks subsurface deposits. Site has moderate research potential and 1 s Judged to be potentially eliglble for listing on NRHP. Recommend mapping and testing. 
41GR287

Location: Ca. $2.8 \mathrm{~km}$ NNE of confluence of Double Mountain Fork and Rocky Creek, and $3.0 \mathrm{~km}$ WNW of confluence of Double Mountain Fork and Little Grape Creek.

Description: Open campsite on small ridge on edge of bluff formed by erosional drainages; elevation 2280-2290 ft msl, area 10,000 $\mathrm{m}^{2}$. Large burned rock feature and lithic scatter with more burned rocks than debitage. Additional scatter of early twentiethcentury trash and possible pothole. Quantity of burned rocks indicates site was used more for camping than lithic procurement. Temporal components are undefined Prehistoric and Historic (see Appendix G for description of historic component).

Features: Large (ca. $3.5 \times 2.5 \mathrm{~m}$ ) cluster of burned sandstone cobbles. Scattered burned rocks could be remains of eroded or deflated features.

Cultural Materials Observed/Collected: Flakes and tested cobbles of Potter chert, local chert, and red coarse-gralned quartzite; and burned fragments of Potter chert and coarse-grained quartzite. No collections made.

Shovel Test Data: One negative shovel test found soil depth of ca. $80 \mathrm{~cm}$.

Assessment/Recommendations: Over $75 \%$ of prehistoric component appears intact; it contains features but lacks subsurface deposits. Prehistoric component has moderate research potential and is judged to be potentially eligible for listing on NRHP. Recommend mapping and testing.

41GR291

Location: Ca. $2.8 \mathrm{~km}$ NNE of confluence of Double Mountain Fork and Rocky Creek, and $3.1 \mathrm{~km}$ WNW of confluence of Double Mountain Fork and Little Grape Creek.

Description: Open campsite on high end of upland ridge flanked by two small drainages; elevation 2260-2290 ft msl, area 52,500 $\mathrm{m}^{2}$. Several burned rock features and 11 thic scatter. Disturbed by dirt road running through center of site and by surface collection. Substantial eolian sand deposits, particularly in west and central areas of site. No temporal components identified; undefined Prehistoric.

Features: Nine clusters of burned rocks: six of burned sandstone and three of Potter chert. Most burned sandstone clusters in west and central areas of site. Most intact of these clusters contains debitage and was exposed in dirt road. Burned Potter chert clusters mainly in shallow, southeastern area of site; only one in western part of site.

Cultural Materlals Observed/Collected: Biface of Edwards chert, sandstone mano, quartzite mano, Potter chert debitage, and worked and tertiary flakes of Edwards chert. Five items collected (see Appendices A and B).

Shovel Test Data: One shovel test was excavated, yielding debitage to $40 \mathrm{~cm}$ below surface. 
Assessment/Recommendations: Over $75 \%$ of site appears intact; it contains subsurface deposits and features. Site has good research potential and is judged to be potentially eligible for listing on NRHP. Recommend controlled surface collection, mapping, and testing.

\section{$\underline{41 G R 293}$}

Location: Ca. $5.2 \mathrm{~km}$ SW of intersection of Garza/Kent county line and Double Mountain Fork, and $2.5 \mathrm{~km} \mathrm{~W}$ of confluence of Double Mountain Fork and Little Grape Creek.

Description: Lithic procurement area on canyon rim overlooking Double Mountain Fork; elevation 2220-2240 ft msl, area 12,500 $\mathrm{m}^{2}$. Sparse scatter of tested cobbles and chipped stone debitage in outcrop of Quaternary gravels. No temporal components identified; undefined Prehistoric.

Features: None.

Cultural Materials Observed/Collected: Tested cobbles and flakes of Potter chert and red coarse-grained quartzite. No collections made.

Shovel Test Data: None.

Assessment/Recommendations: Over $75 \%$ of site appears intact; it lacks subsurface deposits. Site has low research potential and is judged to be not eligible for listing on NRHP. No further work recommended.

\section{GR296}

Location: Ca. $0.2 \mathrm{~km}$ WSW of confluence of Double Mountain Fork and Cat Hollow, and $2.1 \mathrm{~km}$ NNE of confluence of Double Mountain Fork and Rocky Creek.

Description: Lithic procurement area on intermediate and lower terraces of Double Mountain Fork near confluence with Cat Hollow; elevation $2190 \mathrm{ft} \mathrm{msl}$, area $7500 \mathrm{~m}^{2}$. Sparse scatter of lithic debitage in small areas of redeposited gravels. Few burned rocks may be remains of eroded feature. No temporal components identified; undefined Prehistoric.

Features: None.

Cultural Materials Observed/Collected: Six tested cobbles of red coarse-grained quartzite, two Potter chert flakes, flake of yellow local chert, and ca. five fragments of possibly burned Potter chert. No collections made.

Shovel Test Data: None.

Assessment/Recommendations: Over $90 \%$ of site appears intact; it contains no subsurface deposits. Site has low research potential and is judged to be not eligible for listing on NRHP. No further work recommended. 


\section{GR297}

Location: Ca. $0.3 \mathrm{~km}$ WSW of confluence of Double Mountain Fork and Cat Hollow, and $2.0 \mathrm{~km}$ NNE of confluence of Double Mountain Fork and Rocky Creek.

Description: Lithic procurement area on small terrace overlooking Double Mountain Fork; elevation $2215 \mathrm{ft} \mathrm{msl}$, area $2500 \mathrm{~m}^{2}$. Small lithic scatter in 50-m-diameter area. No temporal components identified; undefined Prehistoric.

Features: None.

Cultural Materials Observed/Collected: Tested cobbles and ca. 10 flakes of red coarse-grained quartzite; few fragments of burned Potter chert. No collections made.

Shovel Test Data: None.

Assessment/Recommendations: Over $90 \%$ of site appears intact; it lacks subsurface deposits. Site has low research potential and is judged to be not eligible for listing on NRHP. No further work recommended.

\section{GR300}

Location: Ca. $0.6 \mathrm{~km}$ WSW of confluence of Double Mountain Fork and Cat Hollow, and $2.0 \mathrm{~km}$ NNE of confluence of Double Mountain Fork and Rocky Creek.

Description: Lithic procurement area/open campsite on small upland point overlooking side canyon to the southwest, with larger upland promontory to the northeast; elevation 2260-2270 ft msl, area $375 \mathrm{~m}^{2}$. Scatter of burned rocks and chipped stone debitage containing dense scatter $10 \mathrm{~m}$ in diameter on edge of point overlooking canyon. Lack of tools and diagnostic artifacts may indicate surface collection. No temporal components identified; undefined Prehistoric.

Features: None.

Cultural Materials Observed/Collected: Tested cobbles of Potter chert, flakes of Edwards chert and red coarse-grained quartzite, and fragments of burned limestone and quartzite. No collections made.

Shovel Test Data: One negative shovel test found soil depth of ca. $40 \mathrm{~cm}$.

Assessment/Recommendations: Over $75 \%$ of site appears intact; it lacks subsurface deposits. Site has no research potential and is judged to be not eligible for listing on NRHP. No further work recommended.

\section{$\underline{41 G R 302}$}

Location: Ca. $2.9 \mathrm{~km}$ NNE of confluence of Double Mountaln Fork and Rocky Creek, and $2.8 \mathrm{~km}$ WNW of confluence of Double Mountain Fork and Little Grape Creek. 
Description: Open campsite on erosional bench overlooking small upland drainage; elevation 2270-2280 ft msl, area 22,500 m². First reported by Dr. Robert Campbell between 1974 and 1977; recorded by GRC in 1982, who reported lithic scatter with burned rock features and areas of lithic procurement. Current investigations verified GRC's observations, but procurement areas were not located. Majority of cultural materials are concentrated in southern part of site on small ridge formed by two drainages. Some damage from erosion and dirt road which runs across northern edge of site. Surface collecting also likely. No temporal components identified; undefined Prehistoric.

Features: Two features. First is large (ca. $20 \mathrm{~m}$ diameter) dense cluster of burned Potter chert on point of small ridge, with fragments of burned sandstone in northern edge. To northwest of larger feature, second feature is ca. $2 \mathrm{~m}$ in diameter and consists of burned Potter chert and coarse-grained quartzite.

Cultural Materials Observed/Collected: Gouge preform; burned cobbles and fragments of Potter chert; and flakes of Edwards chert, local chert, and red coarse-grained quartzite. Very little debitage in proportion to burned rocks. GRC noted utilized flakes, hammerstones, and chopper of Potter chert. Nine items collected (see Appendices A and B).

Shovel Test Data: Two shovel tests excavated, both positive. Both yielded cultural materials to ca. $20 \mathrm{~cm}$ below surface. Test near northern edge of large burned rock scatter found soil depth of $23 \mathrm{~cm}$, while test $\mathrm{ca} .15 \mathrm{~m}$ to the northwest found soil depth of at least $60 \mathrm{~cm}$.

Assessment/Recommendations: Over 75\% of site appears intact; it contains subsurface deposits and features. Site has unknown research potential and is judged to be potentially eligible for listing on NRHP. Recommend mapping and testing.

\section{GR303}

Location: Ca. $0.4 \mathrm{~km}$ WNW of confluence of Double Mountain Fork and Cat Hollow, and $2.2 \mathrm{~km}$ NNE of confluence of Double Mountain Fork and Rocky Creek.

Description: Open campsite on top and east slope of upland rise above Cat Hollow drainage; elevation 2220-2310 ft msl, area 70,000 $\mathrm{m}^{2}$. Burned rock feature and lithic scatter. Lower area of site severely eroded; top of rise has shallow deposit of eolian sand where most cultural materials were located. Heavily surface collected. Used for camping or some related activity. No temporal components identified; undefined Prehistoric.

Features: Cluster measuring $3 \times 1 \mathrm{~m}$ containing burned Potter chert and limestone fragments and debitage.

Cultural Materials Observed/Collected: Two bifaces, four scrapers, gouge, and abundant debitage of Edwards chert, local chert, red coarse-grained quartzite, and Potter chert. Fragments of burned Potter chert and limestone. Seven items collected (see Appendices $\mathrm{A}$ and $\mathrm{B}$ ). 
Shovel Test Data: Two shovel tests excavated. Positive test on top of rise yielded cultural materials to $20 \mathrm{~cm}$ and $30 \mathrm{~cm}$ of soil. Negative test next to burned rock feature found soil depth of only $7 \mathrm{~cm}$.

Assessment/Recommendations: Over 50\% of site appears intact; it contains subsurface deposits and features. Site has unknown research potential and is judged to be potentially eligible for listing on NRHP. Recommend mapping and testing.

\section{GR306}

Location: Ca. $0.7 \mathrm{~km}$ WSW of confluence of Double Mountain Fork and Cat Hollow, and $1.8 \mathrm{~km}$ NNE of confluence of Double Mountain Fork and Rocky Creek.

Description: Lithic procurement area/open campsite on two eroded bedrock benches below upland knoll; elevation 2220-2250 ft msl, area 15,000 $\mathrm{m}^{2}$. Lithic scatter concentrated by erosion into small depressions. Minor concentration of cultural materials on east edge of site may be cultural. Soil eroded away almost entirely. No temporal components identified; undefined Prehistoric.

Features: None.

Cultural Materials Observed/Collected: Flakes and tested cobbles of Potter chert, red coarse-grained quartzite, and other quartzite gravels; burned fragments of Potter chert. No collections made.

Shovel Test Data: None.

Assessment/Recommendations: Less than $25 \%$ of site appears intact; it lacks subsurface deposits. Site has no research potential and is judged to be not eligible for listing on NRHP. No further work recommended.

\section{$41 \mathrm{GR} 309$}

Location: Ca. $1.4 \mathrm{~km}$ SSW of confluence of Double Mountain Fork and Grape Creek, and $1.4 \mathrm{~km}$ ENE of confluence of Double Mountain Fork and Little Grape Creek.

Description: Open campsite on canyon rim dissected by several small drainages overlooking Grape Creek; elevation 2220-2260 ft $\mathrm{msl}$, area 25,000 $\mathrm{m}^{2}$. First reported by $\mathrm{Dr}$. Robert Campbell between 1974 and 1977. Recorded by GRC in 1982, who noted scraper, preform, shell fragment, and scatter of burned rocks and debitage. Current investigations verified observations of GRC but also found ground stone tools. Most cultural materials in erosional areas on east edge of site. Site represents camping with some processing. No temporal components Identifled; undefined Prehistoric.

Features: None. 
Cultural Materials Observed/Collected: Six scrapers, two gouges, choppers, mano, and debitage of Potter chert, local chert, red coarse-grained quartzite, and white quartzite; burned sandstone. Nine items collected (see Appendices A and B).

Shovel Test Data: Two shovel tests excavated, one yielding flake at ca. $10 \mathrm{~cm}$, and both indicating soil depth of ca. $15 \mathrm{~cm}$.

Assessment/Recommendations: Over $75 \%$ of site appears intact; it contains subsurface deposits. Site has unknown research potential and is judged to be potentially eligible for listing on NRHP. Recommend mapping and testing.

\section{GR310}

Location: Ca. $1.2 \mathrm{~km}$ NNE of confluence of Double Mountain Fork and Rocky Creek, and $1.2 \mathrm{~km}$ SW of confluence of Double Mountain Fork and Cat Hollow.

Description: Faunal locality in north cutbank of Gobbler Creek; elevation $2185 \mathrm{ft}$ $\mathrm{msl}$, area $20 \mathrm{~m}^{2}$. Articulated bison vertebrae and rib found in 5-m-long area in cutbank ca. $1.2 \mathrm{~m}$ below surface. Charcoal flecks found around bones, but fill screened from face of cutbank yielded no artifacts. Another bone fragment noted in opposite cutbank; remains of more than one individual may be buried in alluvium. Bones may represent an aboriginal bison kill or natural death. No temporal components identified; undefined Prehistoric.

Features: None.

Cultural Materials Observed/Collected: None.

Shovel Test Data: None.

Assessment/Recommendations: Integrity of site is unknown; it preserves subsurface deposits. Site has good research potential and is judged to be potentially eligible for listing on NRHP. Recommend mapping and testing.

$\underline{41 G R 311}$

Location: Ca. $1.4 \mathrm{~km}$ NNE of confluence of Double Mountain Fork and Rocky Creek, and $4.3 \mathrm{~km}$ WSW of confluence of Double Mountain Fork and Little Grape Creek.

Description: Lithic procurement area/open campsite on top of erosional upland remnant forming small knoll northwest of confluence of Double Mountain Fork and Cat Hollow; elevation 2220-2240 ft msl, area $2500 \mathrm{~m}^{2}$. Lithic scatter with concentrations of burned Potter chert in south and central areas of scatter and in erosional area. Gravel and sandstone bedrock exposed on surface probably served as source of lithic materials. Burned Potter chert fragments could be result of camping or heat-treatment. No temporal components identified; undefined Prehistoric.

Features: None. 
Cultural Materials Observed/Collected: Flakes, two cores, and several tested cobbles of red coarse-grained quartzite; flake and numerous fragments of burned Potter chert. No collections made.

Shovel Test Data: None.

Assessment/Recommendations: Over $90 \%$ of site appears intact; it lacks subsurface deposits. Site has no research potential and is judged to be not eligible for listing on NRHP. No further work recommended.

\section{GR312}

Location: $\mathrm{Ca} .0 .3 \mathrm{~km}$ WNW of confluence of Double Mountain Fork and Gobbler Creek, and $1.2 \mathrm{~km}$ SW of confluence of Double Mountain Fork and Cat Hollow.

Description: Open campsite in arroyo cutting through floodplain on north bank of Gobbler Creek; elevation 2175-2185 ft msl, area 11,250 m². Bone fragments and burned rocks eroding out of cutbanks; tools, debitage, burned rocks, and a possible burned rock feature in bottom of arroyo. Only indications of cultural activity on surface of floodplain are few scattered burned rock fragments. Surface collection almost certain. Several historic inscriptions on bluff face less than $100 \mathrm{~m}$ to north are evidence that area has been visited in past. No temporal components identified; undefined Prehistoric.

Features: Cluster of burned sandstone fragments in bottom of arroyo may be deflated hearth or burned rocks eroded out of cutbank and redeposited in arroyo.

Cultural Materials Observed/Collected: Scraper; mano; debitage of Potter chert, Edwards chert, local chert, and red coarse-grained quartzite; burned fragments of sandstone and Potter chert; and two deer bone fragments. Two items collected (see Appendices A and B).

Shovel Test Data: Two shovel tests excavated, one in floodplain surface and other in erosional floodplain remnant in arroyo. Both tests found soil depth of at least $40 \mathrm{~cm}$ and were negative.

Assessment/Recommendations: Over $75 \%$ of site appears intact; it contains subsurface deposits and may have features. Site has unknown research potential and is judged to be potentially eligible for listing on NRHP. Recommend mapping and testing.

\section{GR314}

Location: Ca. $1.4 \mathrm{~km} \mathrm{~N}$ of confluence of Double Mountain Fork and Rocky Creek, and 4.5 $\mathrm{km}$ WSW of confluence of Double Mountain Fork and Little Grape Creek.

Description: Lithic procurement area/open campsite on terrace below large erosional remnant knoll overlooking Gobbler Creek; elevation 2240-2260 ft msl, area $31,250 \mathrm{~m}^{2}$. Scatter of tools, burned rock fragments, and debitage, with one dense concentration of 
burned Potter chert in center of site. Site has been disturbed by oilfield road, well pad, and some bulldozing in center and on east edge. Site margins very eroded, while central part has some soil deposits. No temporal components identified; undefined Prehistoric.

Features: Dense concentration (ca. $10 \mathrm{~m}$ in diameter) of burned Potter chert could be deflated feature.

Cultural Materials Observed/Collected: Scraper, cores, and debitage of Potter chert, Edwards chert, local chert, and red coarse-grained quartzite; burned Potter chert fragments. Three items collected (see Appendices A and B).

Shovel Test Data: One shovel test found cultural materials to ca. $20 \mathrm{~cm}$ and soil depth of ca. $30 \mathrm{~cm}$.

Assessment/Recommendations: Over $75 \%$ of site appears intact; it contains subsurface deposits and may have features. Site has unknown research potential and is judged to be potentially eligible for listing on NRHP. Recommend mapping and testing.

\section{GR315}

Location: $\mathrm{Ca} .1 .2 \mathrm{~km} \mathrm{~N}$ of confluence of Double Mountain Fork and Rocky Creek, and 4.5 $\mathrm{km}$ WSW of confluence of Double Mountain Fork and Little Grape Creek.

Description: Large rock art panel in wind-eroded shelter facing east from steep bluff overlooking mouth of Gobbler Creek; elevation $2220 \mathrm{ft} \mathrm{msl}$, area $16 \mathrm{~m}^{2}$. Shelter, ca. $6.4 \mathrm{~m}$ wide and $2.5 \mathrm{~m}$ deep, has slanting roof ca. $3 \mathrm{~m}$ high at mouth. Rock art on back and sides of shelter, mostly on southern half. No soil deposits in shelter. Temporal components are undefined Prehistoric and Historic (see Appendix G for description of historic component).

Features: Rock art panel ca. $4 \mathrm{~m}$ long and $3.5 \mathrm{~m}$ high with numerous historic inscriptions and four possible aboriginal petroglyphs (see Fig. 3la-d). The four aboriginal elements are mostly geometric, although two are irregular scratchings. Most-distinct elements are circle ca. $12 \mathrm{~cm}$ in diameter with irregular lines radiating from its edges and possible human figure $7 \mathrm{~cm}$ wide and $25 \mathrm{~cm}$ tall. This figure consists of narrow rectangle open at top with chevronlike line extending downward from each bottom corner. Another element ca. $50 \mathrm{~cm}$ tall and ca. $15 \mathrm{~cm}$ wide is a vertical line with horizontal scratchings across it and two intersecting chevrons. Fourth element is three vertical parallel lines with single zigzag line running through them, measuring ca. $20 \mathrm{~cm}$ tall and $20 \mathrm{~cm}$ wide. Latter two elements may be historic drawings or scratchings, but circle with radiating lines and anthropomorphic figure probably are aboriginal petroglyphs.

Cultural Materials Observed/Collected: None.

Shovel Test Data: None.

Assessment/Recommendations: Over $75 \%$ of prehistoric component appears intact. Prehistoric component has moderate research potential and is judged to be potentially eligible for listing on NRHP. No further work recommended because the rock art is of dubious aboriginal origin. 
Location: Ca. $1.1 \mathrm{~km} \mathrm{~N}$ of confluence of Double Mountain Fork and Rocky Creek, and 4.6 km WSW of confluence of Double Mountain Fork and Little Grape Creek.

Description: Lithic procurement area/open campsite on bench below erosional remnant just above mouth of Gobbler Creek; elevation 2240-2260 ft msl, area $2400 \mathrm{~m}^{2}$. Scatter of burned rocks, chipped stone tools, tested cobbles, and debitage. Burned rocks suggest that site was used as camp in addition to lithic procurement area. No temporal components identified; undefined Prehistoric.

Features: None.

Cultural Materials Observed/Collected: Unifacially worked flake; medial biface fragment; tested cobbles and debitage of Potter chert, Edwards chert, local chert, and red coarse-grained quartzite; and burned fragments of Potter chert, red quartzite, and limestone. No collections made.

Shovel Test Data: None.

Assessment/Recommendations: Over $75 \%$ of site appears intact; it lacks subsurface deposits. Site has no research potential and is judged to be not eligible for listing on NRHP. No further work recommended.

\section{$\underline{41 G R 317}$}

Location: Ca. $1.3 \mathrm{~km} \mathrm{~N}$ of confluence of Double Mountain Fork and Rocky Creek, an 4.6 $\mathrm{km}$ WSW of confluence of the Double Mountain Fork and Little Grape Creek.

Description: Rock art site on west-facing bluff erosional upland remnant above mouth of Gobbler Creek; elevation $2220 \mathrm{ft} \mathrm{msl}$, area $12 \mathrm{~m}^{2}$. Fifteen rock art panels on face of protruding shelf of dark sandstone and a recessed face of softer, lighter sandstone below it. Area covered by panels ca. $4 \mathrm{~m}$ long and ca. $1.4 \mathrm{~m}$ tall. Most are historic inscriptions, but four appear to be aboriginal (see Fig. 3le-h). Temporal components are undefined Prehistoric and Historic (see Appendix G for description of historic component).

Features: First of four aboriginal panels is inverted "V" or chevron ca. $3 \mathrm{~cm}$ high and $3 \mathrm{~cm}$ wide below and to left of set of historic initials. Second panel measures ca. 30 $\mathrm{cm}$ long by $\mathrm{ca} .15 \mathrm{~cm}$ tall and consists of four elements: vertical line with two nested chevrons pointing upward at base, arrow-shaped figure formed of two nested chevrons with connecting ends, and two spear-shaped figures composed of single diagonal lines with diamond-shaped figures at lower ends. Third panel measures $7 \mathrm{~cm}$ tall and $5 \mathrm{~cm}$ wide and is diamond-shaped figure with smaller diamond figure adjoining each lower side; three figures together form upward-pointing cardioid. Two vertical lines extend from two bottom points of cardiold. Fourth panel is two diagonal lines intersecting at center, with two small lines extending outward from lower left arm of figure at a point just above end of line. Figure is $8 \mathrm{~cm}$ tall and $13 \mathrm{~cm}$ wide. All panels are on protruding shelf of darker sandstone except for last one, which is on recessed face below. 
Cultural Materials Observed/Collected: None.

Shovel Test Data: None.

Assessment/Recommendations: Over $75 \%$ of prehistoric component appears intact; it preserves features but lacks subsurface deposits. Prehistoric component has excellent research potential and is judged to be potentially eligible for listing on NRHP. Recommend detailed recording (see Table 37 ).

\section{$\underline{41 G R 318}$}

Location: Ca. $1.9 \mathrm{~km}$ NNW of confluence of Double Mountain Fork and Rocky Creek, and $2.0 \mathrm{~km}$ WSW of confluence of Double Mountain Fork and Cat Hollow.

Description: Lithic procurement area on gently sloping bench above bottom of bluff overlooking Gobbler Creek floodplain; elevation 2220-2230 ft msl, area $2400 \mathrm{~m}^{2}$. Sparse scatter of tested cobbles, debitage, and a small amount of burned rocks. Scatter is concentrated near the creek. Not enough burned rocks to suggest habitation; main activity is limited lithic procurement. No temporal components 1dentified; undefined Prehistoric.

Features: None.

Cultural Materials Observed/Collected: Tested cobbles and flakes of red quartzite, white quartzite, local chert, and Potter chert, with burned fragments of Potter chert, sandstone, and limestone. No collections made.

Shovel Test Data: None.

Assessment/Recommendations: Over $90 \%$ of site appears intact; it lacks subsurface deposits. Site has low research potential and is judged to be not eligible for listing on NRHP. No further work recommended.

\section{GR320}

Location: Ca. $1.3 \mathrm{~km}$ NNW of confluence of Double Mountain Fork and Rocky Creek, and $1.6 \mathrm{~km}$ WSW of confluence of Double Mountain Fork and Cat Hollow.

Description: Lithic procurement area on eroded bench below upland margin overlooking Gobbler Creek; elevation 2230-2250 ft msl, area $7500 \mathrm{~m}^{2}$. Large scatter of tested cobbles, debitage, and burned rock fragments concentrated in several areas. Site coincides with outcrop of Quaternary gravels. No temporal components identified; undefined Prehistoric.

Features: None.

Cultural Materials Observed/Collected: Tested cobbles and flakes of Potter chert, red coarse-grained quartzite, local chert, and Edwards chert. No collections made.

Shovel Test Data: None. 
Assessment/Recommendations: Over $75 \%$ of site appears intact; it lacks subsurface deposits. Site has good research potential and is judged to be potentially eligible for listing on NRHP. Recommend mapping and testing.

\section{$41 \mathrm{GR} 323$}

Location: Ca. $1.0 \mathrm{~km}$ SSE of confluence of Double Mountain Fork and Grape Creek, and $2.2 \mathrm{~km}$ ENE of confluence of Double Mountain Fork and Little Grape Creek.

Description: Open campsite on point bar inside bend of Grape Creek, oriented perpendicular to point bar; elevation $2140 \mathrm{ft} \mathrm{msl,} \mathrm{area} 20,000 \mathrm{~m}^{2}$. Two main areas on both ends of site connected by thin artifact scatter. Southern area, ca. $60 \mathrm{~m}$ long and $20 \mathrm{~m}$ wide, includes several burned rock features and scatter of lithic debitage and shell fragments. Northern area, ca. $60 \mathrm{~m}$ in diameter, includes some dispersed burned rock clusters and scatter of shell fragments and lithic debitage but is more eroded. Site appears to have single cultural layer, although multiple camping episodes are represented. No temporal components identified, but radiocarbon assay below site suggests it is Late Prehistoric.

Features: Several burned sandstone features; those in southern area of site are largely intact, contain debitage, and are hearths. Features in northern area of site are clusters of burned sandstone fragments and lithic debris disturbed by erosion.

Cultural Materials Observed/Collected: Flakes of Ogallala chert and Edwards chert, mussel shell fragments, and bone fragment. Twelve items collected (see Appendices A and B).

Shovel Test Data: Two shovel tests excavated, both positive. Northern test yielded cultural materials to ca. $40 \mathrm{~cm}$ and found at least $80 \mathrm{~cm}$ of soil. Southern test yielded abundant cultural materials to ca. $60 \mathrm{~cm}$ and found soil depth of $80 \mathrm{~cm}$.

Radiocarbon Date: Soil sample taken from $1.4 \mathrm{~m}$ below surface in Backhoe Trench 8 (negative) on lower edge of terrace yielded uncalibrated radiocarbon date of $810 \pm 50$ B.P. $(T x-5760)$. Cultural materials found at site may postdate 1140 A.D., placing site's occupation well into Late Prehistoric Period.

Assessment/Recommendations: Over $75 \%$ of site appears intact; it contains subsurface deposits. Site has excellent research potential and is judged to be potentially eligible for listing on NRHP. Recommend mapping and testing.

\section{$41 \mathrm{GR} 324$}

Location: Ca. $3.7 \mathrm{~km} \mathrm{~S}$ of confluence of Double Mountain Fork and Grape Creek, and 2.9 km SE of confluence of Double Mountain Fork and Little Grape Creek.

Description: Lithic procurement area on top and northern slope of erosional remnant overlooking bend in Grape Creek; elevation 2200-2220 ft msl, area $8000 \mathrm{~m}^{2}$. Knoll capped with thin deposit of eolian sand and gravels, while lower slopes have deep sands. Lithic scatter. No temporal components identified; undefined Prehistoric. 
Features: None.

Cultural Materials Observed/Collected: Tested cobbles, core, primary and secondary flakes of Potter chert and local chert, and burned Potter chert cobble. No collections made.

Shovel Test Data: Two negative shovel tests found soil depth of $\mathrm{ca} .30 \mathrm{~cm}$ on top of knoll and at least $60 \mathrm{~cm}$ on alluvial terrace below.

Assessment/Recommendations: Over $50 \%$ of site appears intact; it lacks subsurface deposits. Site has low research potential and is judged to be not eligible for listing on NRHP. No further work recommended.

\section{GR325}

Location: Ca. $3.7 \mathrm{~km}$ SSW of confluence of Double Mountain Fork and Grape Creek, and $6.1 \mathrm{~km} \mathrm{E}$ of confluence of Double Mountain Fork and Rocky Creek.

Description: Open campsite on upper edge of bluff overlooking Grape Creek; elevation 2260-2280 ft msl, area 35,000 $\mathrm{m}^{2}$. Dense lithic scatter in erosional areas, with two burned rock features near edge of bluff. Site eroded near bluff; moderately deep deposits of eolian sand away from bluff edge. Some surface collection. Density of lithic scatter and burned rock features suggest camping frequently or over a period of time. Temporal component identified is Late Prehistoric.

Features: Two burned rock features. One is intact ca. 1-m-diameter cluster of sandstone fragments containing debitage and Deadman's arrow point; other is eroded and deflated cluster of burned sandstone fragments and debitage.

Cultural Materials Observed/Collected: Deadman's arrow point; Washita or Harrell arrow point; arrow point distal fragment; scraper of Alibates agate; hammerstones; mano; and large amount of debitage of Potter chert, local chert, Edwards chert, and coarsegrained quartzite. Nine items collected (see Appendices A and B).

Shovel Test Data: One negative shovel test excavated in area of eolian deposition found soil depth of ca. $55 \mathrm{~cm}$.

Assessment/Recommendations: Over $90 \%$ of site appears intact; it contains subsurface deposits, features, and exotics. Site has good research potential and is judged to be potentially eligible for listing on NRHP. Recommend mapping and testing.

\section{GR326}

Location: Ca. $3.9 \mathrm{~km}$ SSW of confluence of Double Mountain Fork and Grape Creek, and $6.2 \mathrm{~km} \mathrm{E}$ of confluence of Double Mountain Fork and Rocky Creek. 
Description: Rockshelter on bluff slope in eroded area ca. $5 \mathrm{~m}$ below canyon rim; elevation 2240-2250 ft msl, area $18 \mathrm{~m}^{2}$. Shelter, $9 \mathrm{~m}$ long and $3 \mathrm{~m}$ deep, is roofed by dark sandstone caprock and eroded out of softer light gray sandstone. Floor of shelter has deep deposit of eolian sands and roof spalls, and contains cultural materials. Soil exhibits dark brown organic stain which is indication that occupational refuse may be present. These indicate that shelter was occupied, with prehistoric occupation most likely. No temporal components identified; undefined Prehistoric.

Features: None.

Cultural Materials Observed/Collected: Mussel shell fragment, charcoal fragments, and charred seed. Samples of these items collected (see Appendices A and B).

Shovel Test Data: One shovel test excavated contained mussel shell fragment, charcoal fragments, and seed at $40-60 \mathrm{~cm}$ below surface; soil depth at least $1 \mathrm{~m}$.

Assessment/Recommendations: Over $90 \%$ of site appears intact; it contains subsurface deposits. Site has good research potential and is judged to be potentially eligible for listing on NRHP. Recommend mapping and testing.

$\underline{41 G R 327}$

Location: Ca. $3.2 \mathrm{~km}$ SSW of Intersection of Garza/Kent county line and Double Mountain Fork, and $0.4 \mathrm{~km} \mathrm{SE}$ of confluence of Double Mountain Fork and Little Grape Creek.

Description: Lithic procurement area at mouth of Grape Creek in deflated area of canyon rim on both sides of small upland drainage; elevation 2220-2260 ft msl, area 87,500 $\mathrm{m}^{2}$. Scatter of lithic artifacts in outcrop of Quaternary gravels in deflated area. Debitage indicative of early stages of lithic reduction. No temporal components ldentified; undefined Prehistoric.

Features: None.

Cultural Materials Observed/Collected: Tested cobbles, cores, and flakes of Potter chert, red coarse-grained quartzite, and local chert. No collections made.

Shovel Test Data: One negative shovel test indicated soil depth of ca. $44 \mathrm{~cm}$.

Assessment/Recommendations: Over $90 \%$ of site remains intact; it lacks subsurface deposits. Site has good research potential and is judged to be potentially eligible for listing on NRHP. Recommend controlled collection and mapping.

\section{$\underline{41 \mathrm{GR} 328}$}

Location: Ca. $3.4 \mathrm{~km}$ SW of intersection of Garza/Kent county line and Double Mountain Fork, and $4.9 \mathrm{~km}$ ENE of confluence of Double Mountain Fork and Rocky Creek. 
Description: Lithic procurement area/open campsite on canyon rim of Grape Creek in area dissected by small drainage, exposing Quaternary gravels; elevation 2180-2240 ft msl, area $17,500 \mathrm{~m}^{2}$. Scatter of lithic artifacts with burned rock feature. Only early stages of lithic reduction indicated; limited camping or heat-treatment of Potter chert. Manos present support camping interpretation. No temporal components identified; undefined Prehistoric.

Features: One ca. 75-cm-diameter cluster of burned limestone fragments and two tested, burned cobbles of Potter chert.

Cultural Materials Observed/Collected: Two manos (one quartzite and one sandstone); crude biface of Potter chert; tested cobbles, cores, and flakes of Potter chert and red coarse-grained quartzite; burned fragments of Potter chert. No collections made.

Shovel Test Data: One negative shovel test indicated soll depth of $\mathrm{ca} .50 \mathrm{~cm}$.

Assessment/Recommendations: Over $90 \%$ of site appears intact; it preserves features but lacks subsurface deposits. Site has moderate research potential and is judged to be potentially eligible for listing on NRHP. Recommend mapping and testing.

\section{$\underline{41 \text { GR329 }}$}

Location: Ca. $3.6 \mathrm{~km}$ SSW of intersection of Garza/Kent county line and Double Mountain Fork, and $4.8 \mathrm{~km}$ NNE of confluence of Double Mountain Fork and Rocky Creek.

Description: Lithic procurement area on edge of upland margin just above canyon rim on Little Grape Creek; elevation 2200-2240 ft msl, area $7500 \mathrm{~m}^{2}$. Scatter of lithic artifacts within outcrop of Quaternary gravels. Only lithic procurement indicated; no burned rocks. No temporal components identified; undefined Prehistoric.

Features: None.

Cultural Materials Observed/Collected: Bifacially worked flake, hammerstones, tested cobbles, cores, and debitage (mostly primary and secondary flakes) of Potter chert and red coarse-grained quartzite. One item collected (see Appendices A and B).

Shovel Test Data: One negative shovel test indicated soil depth of $\mathrm{ca} .50 \mathrm{~cm}$.

Assessment/Recommendations: Over $90 \%$ of site appears intact; 1 lacks subsurface deposits. Site has good research potential and is judged to be potentially eligible for listing on NRHP. Recommend controlled collection and mapping.

\section{$\underline{41 G R 330}$}

Location: Ca. $3.8 \mathrm{~km}$ SSW of intersection of Garza/Kent county line and Double Mountain Fork, and $4.6 \mathrm{~km}$ ENE of confluence of Double Mountain Fork and Rocky Creek. 
Description: Lithic procurement area/open campsite on upland rise extending downslope to two small knolls on upland margin above Little Grape Creek; elevation 2200-2260 ft msl, area $25,000 \mathrm{~m}^{2}$. Spring on south side of site. Dense scatter of lithic artifacts within Quaternary gravel outcrop with two burned rock features. Area around two knolls eroded. Camping indicated by two burned rock features, and tertiary flakes show tool manufacture; however, lithic procurement probably was most important activity at site. No temporal components identified; undefined Prehistoric.

Features: Two burned rock features; one on top of rise, and one near edge of bluff.

Cultural Materials Observed/Collected: Several blfaces of Potter chert; hammerstones and tested cobbles, cores, and debitage of Potter chert, red coarse-grained quartzite; flakes of Edwards chert; core of Tecovas jasper. No collections made.

Shovel Test Data: One negative shovel test indicated soil depth of ca. $30 \mathrm{~cm}$.

Assessment/Recommendations: Over $75 \%$ of site appears intact; it has features and exotics but lacks subsurface deposits. Site has moderate research potential and is judged to be potentially eligible for listing on NRH. Recommend controlled collection, mapping, and testing.

\section{GR331}

Location: Ca. $0.8 \mathrm{~km} \mathrm{NE}$ of intersection of U.S. Highway 84 and FM 2458 , and $1.5 \mathrm{~km}$ NNW of U.S. Highway 84 bridge over Double Mountain Fork.

Description: Lithic procurement area on upland plateau west of Salt Branch; elevation $2250 \mathrm{ft} \mathrm{msl}$, area $125,000 \mathrm{~m}^{2}$. Five artifact concentration areas, three prehistoric and two historic. Prehistoric lithic scatters on small rises where Quaternary gravels have been exposed by deflation. Largest area roughly 100x60 m; other two areas ca. $60 \mathrm{~m}$ in diameter. Small amount of lithic materials on tiny erosional remnant hillock. No indication of camping, so lithic procurement probably is the only activity represented. Temporal components are undefined Prehistorlc and Historic (see Appendix G for description of historic component).

Features: None.

Cultural Materials Observed/Collected: Bifacially worked cobbles, tested cobbles, cores, hammerstones, and few flakes of Potter chert and red coarse-grained quartzite. No collections made.

Shovel Test Data: One negative shovel test found gravelly soil to ca. $80 \mathrm{~cm}$.

Assessment/Recommendations: Over $90 \%$ of prehistoric component appears intact; it lacks subsurface deposits. Prehistoric component has low research potential and is judged to be not eligible for listing on NRHP. No further work recommended. 
Location: Ca. $6.9 \mathrm{~km} \mathrm{SE}$ of intersection of U.S. Highway 84 and FM 2458 , and $1.8 \mathrm{~km} \mathrm{NE}$ of confluence of Double Mountain Fork and Sand Creek.

Description: Lithic procurement area/open campsite on upper edge of bluff overlooking Double Mountain Fork; elevation 2260-2280 ft msl, area 30,000 $\mathrm{m}^{2}$. Outcrop of Quaternary gravels containing chipped and ground stone tools, tested cobbles, chipping debris, and burned rock features. Extremely disturbed by gravel quarry which occupies nearly half of site area, two oilfield roads which run through eastern edge of site, and abandonded well pad on north edge of site. Few thinning or tertiary flakes, so lithic procurement was main activity; burned rock features probably result from camping. No temporal components identified; undefined Prehistoric.

Features: Six ca. 1.0-1.5-m-diameter clusters of burned sandstone in undisturbed areas of site appear to be intact.

Cultural Materials Observed/Collected: Gouge, scraper, sandstone mano, biface fragment, hammerstones, cores, tested cobbles, and primary and secondary flakes of Potter chert, red coarse-grained quartzite, and local chert. Cores and tested cobbles make up majority of lithic scatter. Four items collected (see Appendices A and B).

Shovel Test Data: One negative shovel test in undisturbed area of site indicated soil depth of $\mathrm{ca} .50 \mathrm{~cm}$.

Assessment/Recommendations: Less than 25\% of site appears intact; it preserves features but lacks subsurface deposits. Site has good research potential and is judged to be potentially eligible for listing on NRHP. Recommend mapping and testing.

\section{GR333}

Location: Ca. $6.9 \mathrm{~km}$ ESE of intersection of U.S. Highway 84 and FM 2458, and $4.1 \mathrm{~km}$ NE of U.S. Highway 84 bridge over Sand Creek.

Description: Rock art site on remnant sandstone pinnacle overlooking Double Mountain Fork; elevation $2250 \mathrm{ft} \mathrm{msl}$, area $100 \mathrm{~m}^{2}$. Wind-carved blow holes in pinnacle contain rock art, mostly historic inscriptions and recent graffiti but also at least one aboriginal element (see Fig. 31i). Any other aboriginal elements in blow hole are totally obscured by historic inscriptions and recent graffiti. Temporal components are undefined Prehistoric and Historic (see Appendix G for description of historic component).

Features: Aboriginal element on roof of upper blow hole is "T" figure with diagonal lines extending down and outward from ends of cross bar, connected by perpendicular lines drawn from their centers to center of vertical line of the "T." Figure is $22 \mathrm{~cm}$ tall and $22 \mathrm{~cm}$ wide.

Cultural Materials Observed/Collected: None. 
Shovel Test Data: None.

Assessment/Recommendations: Over $75 \%$ of prehistoric component appears intact; it preserves features but lacks subsurface deposits. Prehistoric component has moderate research potential and is judged to be potentially eligible for listing on NRHP. No further work recommended, however, because rock art is of dubious aboriginal origin.

\section{GR334}

Location: Ca. $1.1 \mathrm{~km}$ ENE of intersection of U.S. Highway 84 and FM 2458 , and $1.3 \mathrm{~km}$ NNE of U.S. Highway 84 bridge over Double Mountain Fork.

Description: Lithic procurement area on hill on upland margin overlooking Salt Branch; elevation 2230-2240 ft msl, area $60,000 \mathrm{~m}^{2}$. Lithic scatter on erosional remnant covered with Quaternary gravels. Concentration of burned Potter chert in gully below slope south of site; concentrations of chipped stone debris on north end of site and on both sides of gully. Represents use of gravel outcrop as lithic procurement area. No temporal components identified; undefined Prehistoric.

Features: None.

Cultural Materials Observed/Collected: Three crude bifaces of Potter chert, utilized flakes, hammerstones, tested cobbles, cores, and chipping debris of Potter chert and red coarse-grained quartzite. Fragments of burned Potter chert and burned sandstone. One item collected (see Appendices A and B).

Shovel Test Data: One negative shovel test indicated soil depth of ca. $15 \mathrm{~cm}$.

Assessment/Recommendations: Over $90 \%$ of site appears intact; it contains features but lacks subsurface deposits. Site has good research potential and is judged to be potentially eligible for listing on NRHP. Recommend mapping and testing.

\section{$\underline{41 G R 336}$}

Location: Ca. $1.8 \mathrm{~km} \mathrm{~S}$ of confluence of Double Mountain Fork and Little Grape Creek, and $4.4 \mathrm{~km}$ E of confluence of Double Mountain Fork and Rocky Creek.

Description: Open campsite on upland point overlooking confluence of side drainage and Little Grape Creek; elevation 2240-2260 ft msl, area $5000 \mathrm{~m}^{2}$. Sparse scatter of lithic tools and debitage, burned rock fragments, and mussel shell fragment. Site was used for camping or related activities. No temporal components identified; undefined Prehistoric.

Features: None.

Cultural Materials Observed/Collected: Biface, scraper, hammerstone, and chipping debris of Potter chert, Edwards chert, and local chert; fragments of burned sandstone; and mussel shell fragment. One 1tem collected (see Appendices A and B). 
Shovel Test Data: One negative shovel test indicated soil depth of ca. $50 \mathrm{~cm}$.

Assessment/Recommendations: Over $90 \%$ of site appears intact; it lacks subsurface deposits. Site has no research potential and is judged to be not eligible for listing on NRHP. No further work recommended.

\section{$\underline{41 G R 337}$}

Location: Ca. $4.8 \mathrm{~km}$ SSW of intersection of Garza/Kent county line and Double Mountain Fork, and $4.7 \mathrm{~km}$ ESE of confluence of Double Mountain Fork and Rocky Creek.

Description: Lithic procurement area/open campsite on upland margin on eroding point at head of small drainage; elevation 2240-2300 ft msl, area 50,000 $\mathrm{m}^{2}$. Dense scatter of burned rocks, chipped and ground stone tools, cores, tested cobbles, and chipping debris, with burned rock feature and dense burned rock scatter. Tested cobbles suggest lithic procurement, but burned rocks, features, and tools indicate camping. No temporal components identified; undefined Prehistoric.

Features: Two burned sandstone features found near head of drainage. Cluster ca. $1 \mathrm{~m}$ in diameter is comprised of debitage and large $(20 \mathrm{~cm})$ and small pieces of sandstone. Scatter ca. $6 \times 1 \mathrm{~m}$ includes debitage and small fragments of sandstone, and could be result of bulldozing.

Cultural Materials Observed/Collected: Drill fragment, gouge, small biface fragments, manos, hammerstones, cores, tested cobbles, debitage, and burned sandstone fragments. Debitage is of Potter chert, Edwards chert, and red and white coarse-grained quartzite, while cores and tested cobbles are of Potter chert, local chert, and red coarse-grained quartzite. Five items collected (see Appendices A and B).

Shovel Test Data: One shovel test excavated; debitage to $\mathrm{ca} .25 \mathrm{~cm}$ below surface and soils to $35 \mathrm{~cm}$.

Assessment/Recommendations: Over $75 \%$ of site appears intact; it contains subsurface deposits and features. Site has good research potential and is judged to be potentially eligible for listing on NRHP. Recommend mapping and testing.

\section{$41 \mathrm{GR} 338$}

Location: Ca. $2.0 \mathrm{~km}$ SSW of confluence of Double Mountain Fork and Little Grape Creek, and $4.5 \mathrm{~km} \mathrm{E}$ of confluence of Double Mountain Fork and Rocky Creek.

Description: Open campsite on erosional remnant on point overlooking confluence of side drainage and Little Grape Creek; elevation 2200-2250 ft msl, area 10,000 $\mathrm{m}^{2}$. Point has eroded to form two small rocky knolls with flat, deflated area around them. Lithic scatter on flat area includes chipped and ground stone tools, chipping debris, mussel shell fragments, burned rock fragments, and burned rock clusters and concentrations. Possible mortar holes in exposed sandstone on top of one knoll. Burned rock features suggest that 
site was used mainly as camping area. Processing is supported by amount of debitage, tools, and mussel shell fragments. Site has been surface collected. No temporal components identified; undefined Prehistoric.

Features: Six 50-100-cm-diameter, deflated clusters of burned sandstone fragments, three along edge of erosional area in center of site, other three on relatively undisturbed ground.

Cultural Materlals Observed/Collected: Clear Fork gouge, mano, biface of Tecovas jasper, several scrapers and bifaces (most of Edwards chert), few cores, and debitage of predominantly Edwards chert and Potter chert with some red coarse-grained quartzite. Burned rock fragments of sandstone and Potter chert. Seven items collected (see Appendices $A$ and $B$ ).

Shovel Test Data: One shovel test excavated; debitage to ca. $60 \mathrm{~cm}$ and soil depth of ca. $80 \mathrm{~cm}$.

Assessment/Recommendations: Over $50 \%$ of site appears intact; it contains subsurface deposits, features, and exotics. Site has excellent research potential and is judged to be potentially eligible for listing on NRHP. Recommend controlled collection, mapping, and testing.

\section{$\underline{41 G R 339}$}

Location: Ca. $2.7 \mathrm{~km} \mathrm{~S}$ of confluence of Double Mountain Fork and Little Grape Creek, and $4.6 \mathrm{~km}$ ESE of confluence of Double Mountain Fork and Rocky Creek.

Description: Lithic procurement area/open campsite on east edge of Little Grape Creek canyon rim in eroded area dissected by small drainages; elevation 2260-2270 ft msl, area $5625 \mathrm{~m}^{2}$. Sparse scatter of lithic artifacts and a few burned rocks on surface between drainages. Not enough chippable gravels are present to constititute a major 11thic procurement area; burned rocks and tools suggest ephemeral camping. Probably surface collected. No temporal components identified; undefined Prehistoric.

Features: None.

Cultural Materials Observed/Collected: Scraper, mano, biface (possible knife), cores, tested cobbles, and debitage of Potter chert, Edwards chert, and red coarse-grained quartzite. Three items collected (see Appendices A and B).

Shovel Test Data: One negative shovel test found soll deposit ca. $20 \mathrm{~cm}$ deep.

Assessment/Recommendations: Over $75 \%$ of site appears intact; it lacks subsurface deposits. Site has moderate research potential and is judged to be potentially eligible for listing on NRHP. Recommend controlled collection and mapping. 
$\underline{41 G R 340}$

Location: Ca. $3.2 \mathrm{~km} \mathrm{~S}$ of confluence of Double Mountain Fork and Little Grape Creek, and $4.7 \mathrm{~km}$ ESE of confluence of Double Mountain Fork and Rocky Creek.

Description: Lithic procurement area/open campsite on eroded bedrock terrace overlooking Little Grape Creek; elevation 2240-2260 ft msl, area 35,000 $\mathrm{m}^{2}$. Terrace dissected by drainages; sandstone bedrock exposed on edge of terrace, while upslope areas have thick eolian sands. Large scatter of lithic artifacts with numerous burned rock features. Burned rock features and amount of tools and debitage indicate camping and possibly procurement or processing of resources. Due to low incidence of chippable gravels, lithic procurement probably was opportunistic. Considerable evidence of surface collection. Temporal component identified is late Archaic.

Features: Numerous features composed of burned sandstone fragments, most measuring ca. 50-100 cm in diameter. Majority found in erosional areas; however, few farther in from creek have good potential to be undisturbed.

Cultural Materials Observed/Collected: Dart point (untypable, but appears to be late Archaic or early Late Prehistoric), bifaces, scrapers, choppers, sandstone manos, exhausted cores, tested cobbles, and debitage. Tested cobbles are mostly Potter chert; other lithic materials are Potter chert, Edwards chert, red coarse-grained quartzite, and local chert. Burned sandstone fragments. Four items collected (see Appendices A and B).

Shovel Test Data: One shovel test excavated in an area of eolian deposits contained debitage and burned sandstone fragments to $40 \mathrm{~cm}$. Horizontal sandstone fragments may have been part of a feature. Depth of soil is $\mathrm{ca} .90 \mathrm{~cm}$.

Assessment/Recommendations: Over $75 \%$ of site appears intact; it contains subsurface deposits and features. Site has good research potential and is judged to be potentially eligible for listing on NRHP. Recommend controlled collection, mapping, and testing.

\section{$41 \mathrm{GR} 342$}

Location: Ca. $1.9 \mathrm{~km}$ SSE of confluence of Double Mountain Fork and Little Grape Creek, and $4.7 \mathrm{~km}$ ESE of confluence of Double Mountain Fork and Rocky Creek.

Description: Open campsite located outside 1987 project area on edge of upland margin on east side of Little Grape Creek; elevation $2290 \mathrm{ft}$ msl, area $24 \mathrm{~m}^{2}$. Small 1 ithic scatter with single cluster of burned rocks and mussel shell fragments. Scatter measures roughly $15 \mathrm{~m}$ in diameter, probably larger than original site as materials are deflated. Site probably represents single camping episode. No temporal components identified; undefined Prehistoric.

Features: Burned rock cluster ca. $1.5 \mathrm{~m}$ in diameter contains 10-15 large fragments of burned limestone, several burned sandstone slabs, and mussel shell fragments. Feature is very disturbed. 
Cultural Materials Observed/Collected: Fragments of burned sandstone and limestone; flakes of red coarse-grained quartzite. No collections made.

Shovel Test Data: None.

Assessment/Recommendations: Over 90\% of site appears intact; it preserves a feature but lacks subsurface deposits. Site has moderate research potential and is judged to be potentially eligible for listing on NRHP. Recommend mapping and testing.

\section{GR343}

Location: Ca. $1.6 \mathrm{~km}$ SW of intersection of Garza/Kent county line and Double Mountain Fork, and $1.0 \mathrm{~km}$ W of confluence of Double Mountain Fork and Grape Creek.

Description: Lithic procurement area on erosional remnant point separated from main bluff overlooking Double Mountain Fork; elevation 2180-2240 ft msl, area 50,000 $\mathrm{m}^{2}$. Two terrace areas between large pinnacles have thin soil deposits and sparse lithic scatter with a cluster of possibly burned rocks. Not enough debris to be substantial lithic procurement area even though this is only activity represented. No temporal components identified; undefined Prehistoric.

Features: One ca. 50-cm-diameter concentration of possibly burned sandstone fragments, with chipping debris on surface nearby.

Cultural Materials Observed/Collected: Chopper (bifacially flaked cobble) of coarsegrained quartzite, tested cobbles, and debitage (primary and secondary flakes) of Potter chert and red coarse-grained quartzite. Three items collected (see Appendices A and B).

Shovel Test Data: Three shovel tests excavated; two negative tests found soil depth of ca. 10-15 cm. Positive test near burned rock cluster yielded debitage and possibly burned bone fragment in soils to $25 \mathrm{~cm}$.

Assessment/Recommendations: Less than $50 \%$ of site appears intact; it contains subsurface deposits and may have features. Site has low research potential and is judged to be not eligible for listing on NRHP. No further work recommended.

\section{GR344 (Huddleston Shelter)}

Location: Ca. $2.1 \mathrm{~km}$ SW of intersection of Garza/Kent county line and Double Mountain Fork, and $1.3 \mathrm{~km}$ NNE of confluence of Double Mountain Fork and Little Grape Creek.

Description: Rock art site in rockshelter on upper part of bluff overlooking Double Mountain Fork; elevation $2240 \mathrm{ft} \mathrm{msl}$, area $10 \mathrm{~m}^{2}$. Shelter formed when large piece of sandstone caprock broke away, leaving cavity in bluff face. Shelter is ca. $5 \mathrm{~m}$ wide and $2 \mathrm{~m}$ deep; floor covered with deposit of eolian sand and sand fallen from roof with no evidence of cultural deposits. Back wall of shelter is vertical sandstone face ca. $3.8 \mathrm{~m} \mathrm{long}$ and $1.5 \mathrm{~m} \mathrm{high}$. Ca. 35 elements of undefined prehistoric and historic aboriginal rock art; no 
historic inscriptions or recent graffiti. Rock art undamaged except for small amount of spalling and erosion. Temporal components are possible undefined Prehistoric and Historic Aboriginal.

Features: Rock art panel comprised of one large multicomponent element with eight or more isolated elements arrayed around it (see Figs. 45 and 46). Petroglyphs, pictographs, and composite elements present; pictographs dominantly black and red with some white. Superposition and variation in technique suggest multiple time periods. Many elements have historic motifs, but at least one element may be prehistoric.

Large multicomponent element constitutes main part of rock art at site. $\mathrm{Ca} .1 .5 \mathrm{~m}$ long and $0.7 \mathrm{~m} \mathrm{tall}$, it depicts numerous human figures in multiroomed building. Building element has 13 rectangles ("rooms") with 20 human figures drawn inside them. Five figures have red panel within torso; rest are simple line drawings. Most figures wear European clothing; all but one of figures with red pigment have brimmed hats, and three hold staffs. One also has white cross drawn at the top of red torso panel and may represent priest. Another figure has large hat (sombrero?) with short lines radiating from brim. European figures are shown with arms upraised at elbows or bent with hands on hips; legs are bent slightly at knees. Figure with large hat appears to be holding objects, possibly crosses. Figures with staves are ca. $30 \mathrm{~cm}$ tall and $15 \mathrm{~cm}$ wide, while others are only 15-20 cm tall and $15 \mathrm{~cm}$ wide. Most European figures have either hands, feet, or both. Four figures probably represent Indians; none have red pigment, and most are $\mathrm{ca} .10 \mathrm{~cm}$ tall and $7 \mathrm{~cm}$ wide. One wears headdress with bison(?) horns. Other elements within building are cross and inverted triangular figure with smaller triangle at base which could represent bell. Superimposed by building is anthropomorphic figure drawn in black pigment, $33 \mathrm{~cm}$ tall and $18 \mathrm{~cm}$ wide. Figure is floating upside down with hands on hips; torso is oval and hollow. Legs are slightly bent, with feet depicted clearly. Head of figure is drawn in three lobes, resembling cowboy hat.

Isolated elements arrayed around large element consist of ox, crosses, half-figure, two complete figures, tipi, tally marks, and European figure. To left of building is petroglyph of ox or other long-horned bovine, ca. $58 \mathrm{~cm}$ long and $26 \mathrm{~cm}$ tall. Engraved lines depict curved horns, ear, tufted tail, humped back, and hooves. Below ox are four horizontal geometric figures drawn with engraved lines. Above building is single nearhorizontal engraved line with two small crosses drawn above it in white pigment. Above main element is black human figure petroglyph with red pigment in center. Figure is 11 cm tall and $14 \mathrm{~cm}$ wide and has round head, rectangular torso, and arms drawn in form of wide "W." Figure lacks lower torso and legs. Figure to right of building is petroglyph ca. 34 $\mathrm{cm}$ tall and $10 \mathrm{~cm}$ wide; body of black pigment with red panel in torso, and another red patch above head. Arms bent at elbows and rest on hips; legs bowed outward. To upper right of building is anthropomorphic petroglyph figure with triangular head and body and diagonal lines for arms and legs, $9 \mathrm{~cm}$ tall and $7 \mathrm{~cm}$ wide. This element may be prehistoric. To right of building is petroglyph of tipi $23 \mathrm{~cm}$ tall and $27 \mathrm{~cm}$ wide, with ground line below it and chevron to left. Tipi shown in detail, with door flap and tent poles. Below and to right of tipi are three small engraved lines, two perpendicular and third extending diagonally from horizontal one. Petroglyph to far right of building is ca. $36 \mathrm{~cm}$ tall and $20 \mathrm{~cm}$ wide. Consists of 10 diagonal lines which slope upward to right with curved line below them and small triangular figure below and to right of curved line. Petroglyph below building ca. $14 \mathrm{~cm}$ tall and $12 \mathrm{~cm}$ wide has red pigment oval in chest, oustretched arms, hand with fingers, round head, and wide-brimmed hat. 
Cultural Materials Observed/Collected: None.

Shovel Test Data: One negative shovel test excavated found soil depth in shelter of ca. $25 \mathrm{~cm}$.

Assessment/Recommendations: Over 90\% of rock art appears intact; site lacks subsurface deposits. Site has excellent research potential and is judged to be potentially eligible for listing on NRHP. Recommend detailed recording (see Table 37).

\section{GR345}

Location: Ca. $3.0 \mathrm{~km}$ SW of intersection of Garza/Kent county line and Double Mountain Fork, and $1.2 \mathrm{~km} \mathrm{~N}$ of confluence of Double Mountain Fork and Little Grape Creek.

Description: Lithic procurement area on canyon rim in area of small drainage overlooking bend of. Double Mountain Fork; elevation 2240-2260 ft msl, area $6300 \mathrm{~m}^{2}$. Sparse lithic scatter with several rock clusters in area of exposed Quaternary gravels. Site is quite eroded. Only activity represented is lithic procurement. No temporal components Identified; undefined Prehistoric.

Features: Seven 50-100-cm-diameter clusters of from 3 to 10 Potter chert cobbles. Each cluster contains at least one tested cobble, but none have more than three. Two clusters have hammerstones nearby. Features are on exposed bedrock in erosional areas and could have been formed naturally through redeposition. Could represent caches of raw material.

Cultural Materials Observed/Collected: Two hammerstones, local chert biface, thin cobble with bifacial flaking, triangular gouge, cores, tested cobbles, and a small amount of chipping debris. Most of Potter chert; some red coarse-grained quartzite and local chert. One item collected (see Appendices A and B).

Shovel Test Data: One negative shovel test excavated in less-eroded area of site found soll depth of ca. $70 \mathrm{~cm}$.

Assessment/Recommendations: Over $75 \%$ of site appears intact; it contains features but lacks subsurface deposits. Site has good research potential and is judged to be potentially eligible for listing on NRHP. Recommend mapping and testing.

\section{GR347}

Location: Ca. $4.7 \mathrm{~km}$ SW of intersection of Garza/Kent county line and Double Mountain Fork, and $1.9 \mathrm{~km}$ W of confluence of Double Mountain Fork and Little Grape Creek.

Description: Lithic procurement area on edge of upland margin above Double Mountain Fork on erosional remnant terrace of exposed sandstone with small gravel-covered rises; elevation $2220 \mathrm{ft} \mathrm{msl}$, area $5625 \mathrm{~m}^{2}$. Lithic scatter seen mostly on bedrock exposures and in few areas of remaining soil. One cluster of burned rocks noted, but main function of 
site appears to be lithic procurement. No temporal components identified; undefined Prehistoric.

Features: Cluster of three burned sandstone slabs found on exposed bedrock.

Cultural Materials Observed/Collected: Hammerstones, large biface fragment, cores, tested cobbles, and chipping debris of Potter chert and red coarse-grained quartzite. No collections made.

Shovel Test Data: One negative shovel test found soil depth of $68 \mathrm{~cm}$.

Assessment/Recommendations: Over $50 \%$ of site appears intact; it contains features but lacks subsurface deposits. Site has low research potential and is judged to be not eligible for listing on NRHP.

\section{GR348}

Location: Ca. $4.4 \mathrm{~km}$ SW of intersection of Garza/Kent county line and Double Mountain Fork, and $1.2 \mathrm{~km}$ WNW of confluence of Double Mountain Fork and Little Grape Creek.

Description: Lithic procurement area on eroded upland bench below ridge between Double Mountain Fork and small side drainage; elevation 2200-2220 ft msl, area $7500 \mathrm{~m}^{2}$. Sparse scatter of lithic materials concentrated in eroded areas near canyon rim. Abundant Quaternary gravels on surface supplied raw materials. Exploitation of this resource was not great. No temporal components identified; undefined Prehistoric.

Features: None.

Cultural Materials Observed/Collected: Two hamerstones, bifacial core/chopper, unifacially modified flake, cores, tested cobbles, and flakes of Potter chert. No collections made.

Shovel Test Data: One negative shovel test excavated on high edge of bench indicated soil depth of $\mathrm{ca} .37 \mathrm{~cm}$.

Assessment/Recommendations: Over $90 \%$ of site appears intact; it lacks subsurface deposits. Site has good research potential and is judged to be potentially eligible for listing on NRHP. Recommend controlled collection and mapping.

\section{GR349}

Location: Ca. $4.3 \mathrm{~km}$ SW of intersection of Garza/Kent county line and Double Mountain Fork, and $1.7 \mathrm{~km}$ WNW of confluence of Double Mountain Fork and Little Grape Creek.

Description: Lithic procurement area/open campsite on eroding upland point at end of ridge between Double Mountain Fork and large side drainage; elevation 2200-2240 ft msl, area $11,250 \mathrm{~m}^{2}$. High terrace at back of site with exposure of Quaternary gravels; low 
terrace at front of site has small drainage. Diffuse lithic scatter with three burned rock features. Overall site area is deflated. Processing of plant resources accounts for features and manos; however, lithic procurement is main activity represented. No temporal components Identified; undefined Prehistoric.

Features: Three burned rock clusters, one on high terrace and two on low terrace. Possible hearth on high terrace consists of $50-\mathrm{cm}$-diameter circle of Potter chert cobbles with few sandstone fragments and mano. Other two clusters consist of burned sandstone fragments in erosional areas. These possible hearths are ca. $1 \mathrm{~m}$ in diameter and more diffuse.

Cultural Materials Observed/Collected: Cores, tested cobbles, and flakes of Potter chert, Edwards chert (flakes only), local chert, and red coarse-grained quartzite; manos and hammerstones of quartzite; and sandstone mano. Two items collected (see Appendices A and B).

Shovel Test Data: Two shovel tests excavated; one near feature on high terrace indicated soil depth of $\mathrm{ca} .35 \mathrm{~cm}$. Positive test on low terrace revealed debitage to $25 \mathrm{~cm}$ and soil depth of $\mathrm{ca} .30 \mathrm{~cm}$.

Assessment/Recommendations: Over 90\% of site appears intact; it contains subsurface deposits and features. Site has good research potential and is judged to be potentially eligible for listing on NRHP. Recommend mapping and testing.

\section{GR350}

Location: Ca. $4.2 \mathrm{~km}$ WSW of intersection of Garza/Kent county line and Double Mountain Fork, and $2.2 \mathrm{~km}$ NW of confluence of Double Mountain Fork and Little Grape Creek.

Description: Lithic procurement area/open campsite on eroded upland point on west side of unnamed drainage flowing south into Double Mountain Fork; elevation 2200-2280 ft msl, area $45,000 \mathrm{~m}^{2}$. Site contains small erosional remnants. Scatter of prehistoric and historic artifacts with several historic dump areas and two prehistoric clusters of unburned cobbles. Prehistoric scatter extends onto small bench below main part of ridge. Quantity of burned rocks in scatter along with tools may be evidence of camping, but this is not certain. Lithic procurement clearly indicated by amount of tested cobbles, cores, hammerstones, and primary flakes in artifact assemblage. Probably surface collected by historic occupants. Temporal components are undefined Prehistoric and Historic (see Appendix $G$ for description of historic component).

Features: Two clusters of Potter chert cobbles. One on end of ridge is ca. $50 \mathrm{~cm}$ in diameter and is of whole cobbles with hammerstone next to it. Other cluster is approximately same size but is composed of broken cobbles.

Cultural Materials Observed/Collected: Scrapers, two possible Clear Fork gouges, hammerstones, cores, tested cobbles, chipped stone debris, and burned Potter chert and sandstone fragments. Raw materials are Potter chert, red coarse-grained quartzite, local chert, and Edwards chert (mostly tertiary flakes). Five items collected (see Appendices A and $\mathrm{B})$. 
Shovel Test Data: One shovel test excavated yielded debitage at ca. $40 \mathrm{~cm}$ and indicated soil depth of ca. $78 \mathrm{~cm}$.

Assessment/Recommendations: Over $75 \%$ of site appears intact; it contains subsurface deposits and features. Site has good research potential and is judged to be potentially eligible for listing on NRHP. Recommend controlled collection, mapping, and testing.

\section{$\underline{41 G R 351}$}

Location: Ca. $4.3 \mathrm{~km}$ WSW of intersection of Garza/Kent county line and Double Mountain Fork, and $2.1 \mathrm{~km} \mathrm{NW}$ of confluence of Double Mountain Fork and Little Grape Creek.

Description: Lithic procurement area/open campsite on canyon rim overlooking large side drainage flowing south into Double Mountain Fork; elevation 2200-2240 ft msl, area $2600 \mathrm{~m}^{2}$. Small scatter of lithic materials and burned rock feature on lower edge of uplands on both sides of small drainage. Few cultural materials represent lithic procurement. No temporal components identified; undefined Prehistoric.

Features: One ca. 30-cm-diameter cluster of burned sandstone slabs. It appears to be intact and may be remains of small hearth.

Cultural Materials Observed/Collected: Hammerstones of purple coarse-grained quartzite, tested cobbles, and chipping debris (mostly primary and secondary flakes) of Potter chert and coarse-grained quartzite. No collections made.

Shovel Test Data: One negative shovel test indicated soil depth of ca. $35 \mathrm{~cm}$.

Assessment/Recommendations: Less than $50 \%$ of site appears intact; it has features but lacks subsurface deposits. Site has no research potential and is judged to be not eligible for listing on NRHP. No further work recommended.

\section{$\underline{41 G R 352}$}

Location: Ca. $4.3 \mathrm{~km}$ WSW of intersection of Garza/Kent county line and Double Mountain Fork, and ca. $2.0 \mathrm{~km}$ NW of confluence of Double Mountain Fork and Little Grape Creek.

Description: Rock art site in small wind-eroded shelter in bluff face overlooking unnamed drainage east of Cat Hollow; elevation $2200 \mathrm{ft} \mathrm{msl}$, area $6 \mathrm{~m}^{2}$. Single petroglyph (see Fig. 32a) on low slanting roof of shelter. Shelter contains shallow deposit of eolian sand and roof fall; testing found no indication of cultural activity, but shelter may have been occupied for short period of time. No temporal components identified; undefined Prehistoric.

Features: Petroglyph consisting of three parallel diagonal lines, two of equal length, third somewhat shorter. Petroglyph about $5 \mathrm{~cm}$ tall and $6 \mathrm{~cm}$ wide, lines nearly 2 $\mathrm{cm}$ wide. 
Cultural Materials Observed/Collected: None.

Shovel Test Data: One negative shovel test found deposit of sand and sandstone $27 \mathrm{~cm}$ deep.

Assessment/Recommendations: Over $90 \%$ of site appears intact; it contains features but appears to lack subsurface deposits. Site has moderate research potential and is judged to be potentially eligible for listing on NRHP. No further work recommended because rock art is so simple that current records constitute adequate recording.

\section{$\underline{41 G R 353}$}

Location: Ca. $4.2 \mathrm{~km}$ SW of intersection of Garza/Kent county line and Double Mountain Fork, and $1.8 \mathrm{~km}$ WNW of confluence of Double Mountain Fork and Little Grape Creek.

Description: Rock art site in wind-eroded shelter in bluff below 41GR349, overlooking confluence of Double Mountain Fork and unnamed side drainage; elevation 2190-2200 ft msl, area $3 \mathrm{~m}^{2}$. Shelter faces NNE and is $3 \mathrm{~m}$ long and over $1 \mathrm{~m}$ deep. On east wall near opening is single panel of petroglyphs (see Fig. 32b). Floor has shallow deposit of sand (eolian?) and sandstone roof fall. Shovel testing revealed no cultural evidence, so shelter was not inhabited for any length of time. No temporal components identified; undefined Prehistoric.

Features: Single petroglyph panel $11 \mathrm{~cm}$ tall and $16 \mathrm{~cm}$ wide with two elements. First depicts possible arrow with broad, barbed head and shaft; total length $10 \mathrm{~cm}, 3 \mathrm{~cm}$ wide. Other glyph $10 \mathrm{~cm}$ to right consists of two vertical parallel lines $8 \mathrm{~cm}$ long and $2 \mathrm{~cm}$ apart.

Cultural Materials Observed/Collected: None.

Shovel Test Data: One negative shovel test indicated depth of soil deposit 1s ca. 18 Cln.

Assessment/Recommendations: Over $90 \%$ of site appears intact; it preserves features but may lack subsurface deposits. Site has excellent research potential and is judged to be potentially eligible for listing on NRP. Recommend detailed recording (see Table 37 ).

\section{$\underline{41 \mathrm{GR} 354}$}

Location: Ca. $3.6 \mathrm{~km}$ SW of intersection of Garza/Kent county line and Double Mountain Fork, and $0.8 \mathrm{~km}$ WNW of confluence of Double Mountain Fork and Little Grape Creek.

Description: Rock art site in wind-eroded shelter on lower slopes of bluff overlooking small drainage in Double Mountain Fork floodplain; elevation $2220 \mathrm{ft} \mathrm{ms} 1$, area $3 \mathrm{~m}^{2}$. Shelter roofed by dark brown sandstone caprock, with walls and floor eroded out of underlying softer light brown sandstone. Petroglyph (see Fig. 32c) on interior side of sandstone pillar at front of shelter. No soll deposits or cultural materials on narrow, sloping shelter floor. No temporal components Identified; undefined Prehistoric. 
Features: Two parallel diagonal lines engraved into sandstone ca. 2 cm apart; upper line $7 \mathrm{~cm}$ long and lower $6 \mathrm{~cm}$ long. Panel is $5.5 \mathrm{~cm}$ tall and $6 \mathrm{~cm}$ wide. Lines could be natural.

Cultural Materials Observed/Collected: None.

Shovel Test Data: None.

Assessment/Recommendations: Over $90 \%$ of site appears intact; it contains features but lacks subsurface deposits. Site has moderate research potential and is judged to be potentially eligible for listing on NRHP. No further work recommended, however, because art is so simple that current recording is adequate and because art is of dublous aboriginal origin.

\section{$\underline{41 G R 356}$}

Location: Ca. $0.1 \mathrm{~km}$ SSE of confluence of Double Mountain Fork and Little Grape Creek, and $2.5 \mathrm{~km}$ SW of confluence of Double Mountain Fork and Grape Creek.

Description: Open campsite (single hearth) in cutbank of upper alluvial terrace of Little Grape Creek ca. 80 m upstream of confluence with Double Mountain Fork; elevation $2160 \mathrm{ft} \mathrm{msl}$, area $25 \mathrm{~m}^{2}$. No other evidence of cultural activity found in fill around feature, which was troweled and screened. Appears to be remains of single camping episode. No temporal components identified; undefined Prehistoric.

Features: Disturbed hearth in cutbank ca. $50 \mathrm{~cm}$ below ground surface; estimated to be ca. $60 \mathrm{~cm}$ in diameter, with three sandstone slabs still in situ and charcoal flecks and ashy soll beneath them.

Cultural Materials Observed/Collected: None.

Shovel Test Data: Two negative shovel tests in terrace above feature -- one immediately above feature, other ca. $10 \mathrm{~m}$ back from cutbank -- indicated soll depth of at least $75 \mathrm{~cm}$.

Assessment/Recommendations: Less than $10 \%$ of site appears intact; it contains a feature and limited subsurface deposits. Site has no research potential and is judged to be not eligible for listing on NRHP. No further work recommended.

\section{GR359}

Location: Ca. $2.8 \mathrm{~km}$ SW of intersection of Garza/Kent county line and Double Mountain Fork, and $1.1 \mathrm{~km}$ WSW of confluence of Double Mountain Fork and Little Grape Creek.

Description: Lithic procurement area/open campsite on canyon rim overlooking Double Mountain Fork on side of small box canyon; elevation 2200-2260 ft msl, area $20,400 \mathrm{~m}^{2}$. Large, diffuse lithic scatter with four burned rock clusters. Site area dissected by three 
drainages; area between two has artifact concentration ca. $50 \mathrm{~m}$ in diameter. Good exposures of Quaternary gravels in several areas of site. Site saw considerable use as camping area, with lithic procurement from available chippable gravels. Temporal component noted is middle Archaic.

Features: Four 50-200-cm-diameter clusters of burned sandstone, some dispersed by erosion.

Cultural Materials Observed/Collected: Untyped stemmed dart point, unidentifiable dart point, biface (possible knife) fragment, choppers, sandstone mano, cores, tested cobbles, chipped stone debris, and burned sandstone fragments. Raw materials represented are Potter chert, redđish coarse-grained quartzite, Edwards chert, and local chert. The Edwards chert occurs primarily as tertiary debitage. Sixteen items collected (see Appendices $A$ and $B)$.

Shovel Test Data: One shovel test excavated within artifact concentration contained cultural materials to $\mathrm{ca} .40 \mathrm{~cm}$ and indicated soil depth of ca. $43 \mathrm{~cm}$.

Assessment/Recommendations: Over 75\% of site appears intact; it contains features and subsurface deposits. Site has excellent research potential and is judged to be potentially eligible for listing on NRHP. Recommend controlled collection, mapping, and testing.

\section{$\underline{41 G R 360}$}

Location: Ca. $3.6 \mathrm{~km}$ SW of intersection of Garza/Kent county line and Double Mountain Fork, and $0.5 \mathrm{~km}$ WSW of confluence of Double Mountain Fork and Little Grape Creek.

Description: Lithic procurement area on rise at edge of upland margin over Double Mountain Fork; elevation 2220-2250 ft msl, area $3000 \mathrm{~m}^{2}$. Robert Campbell first reported cultural materials here. Scatter of lithic artifacts with two abandoned farm trailers dating to 1940 s or 1950 s parked on site. Surface of site deflated; Quaternary gravels exposed on surface. Main activity at the site was lithic procurement, with some other activity indicated by single scraper. No temporal components identified; undefined Prehistoric.

Features: None.

Cultural Materials Observed/Collected: Scraper, hammerstone, cores, tested cobbles, chipping debris, and retouched debitage. Raw materials are Potter chert and red coarsegrained quartzite. No collections made.

Shovel Test Data: One negative shovel test indicated soil depth of ca. $40 \mathrm{~cm}$.

Assessment/Recommendations: Over $90 \%$ of site appears intact; it lacks subsurface deposits. Site has low research potential and is judged to be not eligible for listing on NRHP. No further work recommended. 
Location: Ca. $5.0 \mathrm{~km}$ SW of intersection of Garza/Kent county line and Double Mountain Fork, and $2.0 \mathrm{~km}$ WSW of confluence of Double Mountain Fork and Little Grape Creek.

Description: Lithic procurement area on top and slopes of eroding ridge between Double Mountain Fork and large side drainage; elevation 2200-2260 ft msl, area $8000 \mathrm{~m}^{2}$. Lithic scatter corresponding with Potter chert outcrop. Large lithic procurement area with burned rocks from some related activity. No temporal components identified; undefined Prehistoric.

Features: None.

Cultural Materials Observed/Collected: Hammerstones, cores, tested cobbles, and chipping debris of Potter chert, reddish coarse-grained quartzite, and some Edwards chert. Burned rocks are Potter chert and sandstone. No collections made.

Shovel Test Data: None.

Assessment/Recommendations: Over $90 \%$ of site appears intact; it lacks subsurface deposits. Site has low research potential and is judged to be not eligible for listing on NRHP. No further work recommended.

\section{GR362}

Location: Ca. $5.0 \mathrm{~km}$ SW of intersection of Garza/Kent county line and Double Mountain Fork, and $2.9 \mathrm{~km}$ WSW of confluence of Double Mountain Fork and Little Grape Creek.

Description: Lithic procurement area on erosional remnant terrace overlooking side drainage of Double Mountain Fork; elevation 2260-2300 ft msl, area $7500 \mathrm{~m}^{2}$. Lithic scatter in area of bedrock and gravels exposed on surface. Only activity clearly represented is lithic procurement, although chopper could indicate vegetal procurement. No temporal components identified; undefined Prehistoric.

Features: None.

Cultural Materials Observed/Collected: Chopper, cores, tested cobbles, chipping debris, and burned rock fragments of Potter chert. No collections made.

Shovel Test Data: One negative shovel test in area of site with soll deposition found soll depth of ca. $20 \mathrm{~cm}$.

Assessment/Recommendations: Over $90 \%$ of site appears intact; it lacks subsurface deposits. Site has good research potential and is judged to be potentially eligible for listing on NRHP. Recommend mapping and testing. 
Location: Ca. $2.3 \mathrm{~km}$ NE of confluence of Double Mountain Fork and Rocky Creek, and $2.8 \mathrm{~km}$ WSW of confluence of Double Mountain Fork and Little Grape Creek.

Description: Lithic procurement area/open campsite on canyon rim on point overlooking confluence of two small drainages; elevation 2230-2270 ft msl, area 10,000 $\mathrm{m}^{2}$. Lithic scatter with clusters of burned rocks. Features probably indicate use for camping, with 11thic procurement also. Evidence of surface collection. No temporal components identifled; undefined Prehistoric.

Features: Six burned rock features. Five ca. 50-75-cm-diameter clusters of burned sandstone; one ca. 50-cm-dlameter cluster of burned Potter chert fragments and cobbles.

Cultural Materlals Observed/Collected: Multifunction tool (reamer and scraper), mano fragment, tested cobbles, cores, chipping debris, and fragments of burned sandstone and Potter chert. Raw materials are local chert, Potter chert, and red coarse-grained quartzite. One item collected (see Appendices A and B).

Shovel Test Data: One negative shovel test indicated soll depth of at least $100 \mathrm{~cm}$.

Assessment/Recommendations: Over $90 \%$ of site appears intact; it has features and may contain subsurface deposits. Site has unknown research potential and is judged to be potentlally eligible for listing on NRHP. Recommend controlled collection, mapping, and testing.

\section{$41 \mathrm{GR} 364$}

Location: Ca. $2.1 \mathrm{~km} \mathrm{NE}$ of confluence of Double Mountain Fork and Rocky Creek, and $2.9 \mathrm{~km}$ WSW of confluence of Double Mountain Fork and Little Grape Creek.

Description: Lithic procurement area/open campsite on upland point between two drainages; elevation 2260-2290 ft msl, area $6000 \mathrm{~m}^{2}$. Lithic scatter with burned rock feature in deflated, rocky area. Has been surface collected. Limited lithic procurement and camplng evident. No temporal components identified; undefined Prehistoric.

Features: Ca. 70-cm-diameter cluster of burned sandstone fragments.

Cultural Materials Observed/Collected: Potter chert gouge, cores, tested cobbles, and chipping debris (mostly primary and secondary flakes) of Potter chert, red coarse-grained quartzite, and local chert, with two pieces of possible Tecovas jasper. Two items collected (see Appendices A and B).

Shovel Test Data: One shovel test ylelded possible flake between 0-20 cm and found solls to $\mathrm{ca} .95 \mathrm{~cm}$.

Assessment/Recommendations: Over $75 \%$ of site appears intact; it contains features and exotics but may lack subsurface deposits. Site has no research potential and is judged to be not eligible for listing on NRHP. No further work recommended. 


\section{GR365}

Location: Ca. $2.0 \mathrm{~km}$ NE of confluence of Double Mountain Fork and Rocky Creek, and $3.0 \mathrm{~km}$ WSW of confluence of Double Mountain Fork and Little Grape Creek.

Description: Lithic procurement area on canyon rim overlooking side drainage of Double Mountain Fork; elevation 2260-2290 ft msl, area $3500 \mathrm{~m}^{2}$. Scatter of lithic debris in Quaternary gravel exposure, with 25-m-diameter concentration of cultural materials on north end of site. No temporal components identifled; undefined Prehistoric.

Features: None.

Cultural Materials Observed/Collected: Cores, tested cobbles, and large flakes of Potter chert, local chert, and red coarse-grained quartzite. No collections made.

Shovel Test Data: One negative shovel indicated soil depth of ca. $38 \mathrm{~cm}$.

Assessment/Recommendations: Over $50 \%$ of site appears intact; it lacks subsurface deposits and has sparse cultural materials. Site has low research potential and is judged to be not eligible for listing on NRHP. No further work recommended.

\section{GR366}

Location: Ca. $1.9 \mathrm{~km}$ NE of confluence of Double Mountain Fork and Rocky Creek, and $3.0 \mathrm{~km}$ WSW of confluence of Double Mountain Fork and Little Grape Creek.

Description: Lithic procurement area on upland point on canyon rim overlooking side drainage of Double Mountain Fork; elevation 2260-2280 ft msl, area $3750 \mathrm{~m}^{2}$. Quaternary gravels exposed in areas dissected by small drainages. Lithic scatter with fire-cracked rocks in one area. Lithic procurement area with possible heat-treatment activity. No temporal components identified; undefined Prehistoric.

Features: None.

Cultural Materials Observed/Collected: Scraper of dark gray quartzite; cores, tested cobbles, flakes, and burned rock fragments of Potter chert and Ogallala quartzite. One item collected (see Appendices $A$ and B).

Shovel Test Data: One negative shovel test found soll depth of ca. $45 \mathrm{~cm}$.

Assessment/Recommendations: Over $75 \%$ of site appears intact; it lacks subsurface deposits. Site has low research potential and is judged to be not eligible for listing on NRHP. No further work recommended.

\section{$41 \mathrm{GR} 367$}

Location: Ca. $5.6 \mathrm{~km}$ SW of intersection of Garza/Kent county line and Double Mountain Fork, and $2.6 \mathrm{~km}$ WSW of confluence of Double Mountain Fork and Little Grape Creek. 
Description: Lithic procurement area on erosional remnant on margin of uplands; elevation 2240-2280 ft msl, area 30,000 $\mathrm{m}^{2}$. Lithic scatter in exposure of bedrock and gravels. Main activity represented is 1ithic procurement. No temporal components identified; undefined Prehistoric.

Features: None.

Cultural Materials Observed/Collected: Two unffacial tools, cores, tested cobbles, and chipping debris (mostly primary and secondary) of Potter chert and coarse-grained quartzite, with some Edwards chert. Burned Potter chert fragments. One item collected (see Appendices A and B).

Shovel Test Data: One negative shovel test in less-eroded part of site found soil depth of ca. $40 \mathrm{~cm}$.

Assessment/Recommendations: Over $50 \%$ of site appears intact; it lacks subsurface deposits. Site has good research potential and is judged to be potentially eligible for listing on NRHP. Recommend mapping and testing.

\section{GR368}

Location: Ca. $5.4 \mathrm{~km}$ SW of intersection of Garza/Kent county line and Double Mountain Fork, and $2.4 \mathrm{~km}$ WSW of confluence of Double Mountain Fork and Little Grape Creek.

Description: Open campsite on upland margin on small deflated point overlooking Double Mountain Fork and erosional drainage area; elevation $2285 \mathrm{ft} \mathrm{msl}$, area $2025 \mathrm{~m}^{2}$. Lithic scatter on exposed bedrock or in pockets of eolian sands. Uncertain what activities represented because of few cultural materials. No temporal components identified; undefined Prehistoric.

Features: None.

Cultural Materials Observed/Collected: Snub-nosed Edwards chert scraper, unifacially modified Potter chert flake, two Potter chert flakes, and burned Potter chert fragment. One item collected (see Appendices A and B).

Shovel Test Data: One negative shovel test in pocket of eolian sand found soil depth of ca. $32 \mathrm{~cm}$.

Assessment/Recommendations: Over $90 \%$ of site appears intact; it lacks subsurface deposits. Site has no research potential and is judged to be not eligible for listing on NRHP. No further work recommended.

$\underline{41 G R 369}$

Location: Ca. $1.8 \mathrm{~km}$ NNE of confluence of Double Mountain Fork and Rocky Creek, and $1.0 \mathrm{~km}$ SSE of confluence of Double Mountain Fork and Cat Hollow. 
Description: Open campsite on eroding upland slope at head of small tributary to Double Mountain Fork; elevation $2260 \mathrm{ft} \mathrm{msl,} \mathrm{area} 75 \mathrm{~m}^{2}$. Thin scatter of flakes surrounding cluster of burned rocks. May represent campsite used more than one time. No temporal components identified; undefined Prehistoric.

Features: One ca. 40-cm-diameter cluster of three burned sandstone slabs and numerous smaller fragments.

Cultural Materials Observed/Collected: Potter chert flakes. No collections made.

Shovel Test Data: None.

Assessment/Recommendations: Over $90 \%$ of site appears intact; it contains a feature but lacks subsurface deposits. Site has moderate research potential and is judged to be potentially eligible for listing on NRHP. Recommend mapping and testing.

\section{GR371}

Location: Ca. $1.6 \mathrm{~km}$ NNW of confluence of Double Mountain Fork and Rocky Creek, and $1.9 \mathrm{~km}$ WSW of confluence of Double Mountain Fork and Cat Hollow.

Description: Lithic procurement area on erosional bench on valley slopes overlooking Gobbler Creek; elevation 2210-2265 ft msl, area 41,800 $\mathrm{m}^{2}$. Outcrop of Quaternary gravels containing a lithic scatter. Lithic procurement area where cobbles were tested. No temporal components Identified; undefined Prehistoric.

Features: None.

Cultural Materials Observed/Collected: Tested cobbles, flakes, and fragments of burned Potter chert and red coarse-grained quartzite. Few flakes of Edwards chert. No collections made.

Shovel Test Data: None.

Assessment/Recommendations: Over $90 \%$ of site appears intact; it lacks subsurface deposits. Site has low research potential and is judged to be not eligible for listing on NRHP. No further work recommended.

\section{$\underline{41 \mathrm{GR} 372}$}

Location: Ca. $1.1 \mathrm{~km}$ WNW of confluence of Double Mountain Fork and Cat Hollow, and $2.3 \mathrm{~km} \mathrm{~N}$ of confluence of Double Mountain Fork and Rocky Creek.

Description: Open campsite in plowed field on level upland west of Cat Hollow and north of Cedar Hill; elevation $2320 \mathrm{ft} \mathrm{msl}$, area $9000 \mathrm{~m}^{2}$. Scatter $(100 \times 50 \mathrm{~m})$ of burned rock fragments and cores. Damage undoubtedly has occurred from plowing; some cores could be result of plow damage to natural cobbles, and artifacts have been scattered by plowing. 
Camping or cooking are likely activites, as well as some lithic reduction. No temporal components identified; undefined Prehistoric.

Features: None.

Cultural Materials Observed/Collected: Cores and burned fragments of Potter chert and red coarse-grained quartzite. Three items collected (see Appendices A and B).

Shovel Test Data: One shovel test ylelded cultural materials to ca. $40 \mathrm{~cm}$ and found soil depth of ca. $37 \mathrm{~cm}$.

Assessment/Recommendations: Less than 10\% of site appears intact; it may contain subsurface deposits. Site has no research potential and is judged to be not eligible for 11sting on NRHP. No further work recommended.

\section{$\underline{41 \mathrm{GR} 373}$}

Location: Ca. $0.8 \mathrm{~km}$ NW of confluence of Double Mountain Fork and Cat Hollow, and 2.5 $\mathrm{km}$ NNE of confluence of Double Mountain Fork and Rocky Creek.

Description: Lithic scatter at edge of plowed field near head of Cat Hollow; elevation $2290 \mathrm{ft} \mathrm{msl}$, area $1000 \mathrm{~m}^{2}$. Sparse scatter of chipped and ground stone tools and chipping debris in and along dirt road. Charcoal staining in soil next to road in one area is most likely remains of brush-clearing fires. Tools found are suggestive of vegetal procurement or processing. No temporal components identified; undefined Prehistoric.

Features: None.

Cultural Materials Observed/Collected: Quartzite mano, chopper of Potter chert, cobble and flake of Potter chert, and possibly burned fragment of sandstone. Two artifacts collected (see Appendices A and B).

Shovel Test Data: One negative shovel test in plowed field to north of road indicated soll depth of at least $40 \mathrm{~cm}$.

Assessment/Recommendations: Less than 10\% of site appears intact; it lacks subsurface deposits. Site has low research potentlal and is judged to be not eligible for listing on NRHP. No further work recommended.

\section{GR374}

Location: Ca. $1.7 \mathrm{~km}$ NNW of confluence of Double Mountain Fork and Rocky Creek, and $1.6 \mathrm{~km}$ WSW of confluence of Double Mountain Fork and Cat Hollow.

Description: Open campsite on upland finger ridge flanked by large erosional areas overlooking eroded and scoured Gobbler Creek floodplain; elevation $2280 \mathrm{ft}$ msl, area 17,500 $\mathrm{m}^{2}$. Sparse lithic scatter with burned rock cluster; artifacts are concentrated around 
feature. Somewhat disturbed by oilfield road which runs through west edge of site. Burned rock cluster and tools indicate camping activity or vegetal resource processing or procurement. No temporal components identified; undefined Prehistoric.

Features: Burned sandstone cluster ca. $2 \mathrm{~m}$ in diameter, with flakes and chopperlike worked pebble nearby.

Cultural Materials Observed/Collected: Two choppers of Potter chert, scraper of red coarse-grained quartzite, and flakes and fragments of Potter chert and coarse-grained quartzite. One item collected (see Appendices A and B) .

Shovel Test Data: One negative shovel test found soll depth of ca. $47 \mathrm{~cm}$.

Assessment/Recommendations: Over $90 \%$ of site appears intact; it has features but lacks subsurface deposits. Site has no research potential and is judged to be not eligible for listing on NRHP. No further work recommended.

\section{$\underline{41 \mathrm{GR} 376}$}

Location: Ca. $1.6 \mathrm{~km} \mathrm{~N}$ of confluence of Double Mountain Fork and Rocky Creek, and 4.4 km WSW of confluence of Double Mountain Fork and Little Grape Creek.

Description: Lithic procurement area/open campsite on top of mesa and lower terrace overlooking confluence of Double Mountain Fork and Gobbler Creek; elevation 2280-2300 ft msl, area $35,000 \mathrm{~m}^{2}$. Quaternary gravels exposed on deflated surfaces of mesa and lower terrace contain lithic scatter. Burned rock concentrations on top of mesa; lower terrace has primarily tested cobbles and chipping debris. Damaged slightly by pipeline which runs through center of site and by surface collection. Top of mesa used for camping and lithic reduction with some lithic procurement, while lower terrace used mainly for lithic procurement. Temporal component identified is undefined Archaic.

Features: None.

Cultural Materials Observed/Collected: Untyped large corner-notched dart point fragment, two gouges, scrapers, modified flakes, and chipped stone debris; tools are of Potter chert and red coarse-grained quartzite, while debitage and dart point are of Edwards chert. Small amount of Tecovas jasper also present. Burned rocks are of Potter chert. Thirteen items collected (see Appendices A and B).

Shovel Test Data: One shovel test yielded cultural materials to $\mathrm{ca} .40 \mathrm{~cm}$, with scraper at $30 \mathrm{~cm}$. Soll depth was $\mathrm{ca} .43 \mathrm{~cm}$.

Assessment/Recommendations: Over $75 \%$ of site appears intact; it contains subsurface deposits and exotics. Site has excellent research potential and is judged to be potentially eligible for listing on NRHP. Recommend controlled collection, mapping, and testing. 
Location: Ca. $1.3 \mathrm{~km}$ NNW of confluence of Double Mountain Fork and Rocky Creek, and $1.6 \mathrm{~km}$ WSW of confluence of Double Mountain Fork and Cat Hollow.

Description: Lithic procurement area/open campsite on deflated mesa top overlooking Gobbler Creek floodplain; elevation $2280 \mathrm{ft} \mathrm{msl}$, area $2400 \mathrm{~m}^{2}$. Lithic scatter in outcrop of Quaternary gravels. Surface collection evident. Artifacts are indicative of lithic procurement, but tools and burned rocks suggest camping or vegetal processing. No temporal components identified; undefined Prehistoric.

Features: None.

Cultural Materials Observed/Collected: Unifacial Potter chert chopper, small bifacially worked cobble of gray fine-grained quartzite, tested cobbles and flakes of Potter chert and red coarse-grained quartzite, Edwards chert flakes, and burned Potter chert fragments. Two items collected (see Appendices A and B).

Shovel Test Data: One negative shovel test indicated soll depth of ca. $30 \mathrm{~cm}$.

Assessment/Recommendations: Over $50 \%$ of site appears intact; it lacks subsurface deposits. Site has no research potential and is judged to be not eligible for listing on NRHP. No further work recommended.

\section{GR378}

Location: Ca. $1.7 \mathrm{~km}$ NNW of confluence of Double Mounatin Fork and Rocky Creek, and $1.6 \mathrm{~km}$ WSW of confluence of Double Mountain Fork and Cat Hollow.

Description: Lithic procurement area/open campsite on eroding canyon rim on both sides of upland drainage flowing into Gobbler Creek; elevation 2260-2280 ft msl, area $22,500 \mathrm{~m}^{2}$. Sparse lithic scatter in deposit of Quaternary gravels. Site is eroded; several large clusters of burned rocks in one erosional area. Main activity seems to be lithic reduction, with some camping indicated by burned rock features. No temporal components Identified; undefined Prehistoric.

Features: Several large (ca. $1.5 \mathrm{~m}$ diameter), diffuse clusters of burned fragments of sandstone and Potter chert. Features appear to be in situ, although slightly eroded.

Cultural Materials Observed/Collected: Two crude choppers of Potter chert; tested cobbles and flakes of Potter chert, red coarse-grained quartzite, and local chert; and a few flakes of Edwards chert. Fragments of burned sandstone and Potter chert. One 1 tem collected (see Appendices A and B).

Shovel Test Data: One shovel test found cultural materials from $20-40 \mathrm{~cm}$ below surface and indicated soil depth of $80 \mathrm{~cm}$. 
Assessment/Recommendations: Over $75 \%$ of site appears intact; it contains features and subsurface deposits. Site has good research potential and is judged to be potentially eligible for listing on NRHP. Recommend controlled collection, mapping, and testing.

\section{$\underline{41 G R 379}$}

Location: Ca. $1.8 \mathrm{~km}$ NNW of confluence of Double Mountain Fork and Rocky Creek, and $5.2 \mathrm{~km}$ WSW of confluence of Double Mountain Fork and Little Grape Creek.

Description: Lithic procurement area/open campsite on eroding canyon rim and bench area below it, overlooking Gobbler Creek; elevation $2270 \mathrm{ft}$ msl, area $7850 \mathrm{~m}^{2}$. Lithic scatter concentrated on bench, with three burned rock features on higher edge of bench. More evidence for camping activities than for lithic procurement, although both were taking place. Somewhat disturbed by pipeline which runs through center of site. No temporal components identified; undefined Prehistoric.

Features: Three features; two interpreted as being result of cooking or food processing with Potter chert bolling stones. These clusters of burned Potter chert fragments and sandstone fragments vary in size; one is ca. $150 \mathrm{~cm}$ in diameter, the other is 50 $\mathrm{cm}$ in diameter. Third feature is small (ca. $50 \mathrm{~cm}$ diameter) cluster of burned sandstone fragments which may be hearth.

Cultural Materials Observed/Collected: Choppers of Potter chert, cores and chipping debris of Potter chert and red coarse-grained quartzite, a few flakes of Edwards chert, and fragments of burned sandstone and Potter chert. Four items collected (see Appendices A and B).

Shovel Test Data: Two shovel tests excavated; both yielded cultural materials to ca. $20 \mathrm{~cm}$ and found soil depths of $20-30 \mathrm{~cm}$.

Assessment/Recommendations: Over $90 \%$ of site appears intact; it contains features and subsurface deposits. Site has moderate research potential and is judged to be potentially eligible for listing on NRHP. Recommend mapping and testing.

\section{$\underline{41 G R 380}$}

Location: Ca. $1.6 \mathrm{~km}$ NNW of confluence of Double Mountain Fork and Rocky Creek, and $1.7 \mathrm{~km}$ WSW of confluence of Double Mountain Fork and Cat Hollow.

Description: Lithic procurement area on series of small points separated by drainages on upland margin; elevation 2240-2270 ft msl, area 42,000 $\mathrm{m}^{2}$. Outcrops of Quaternary gravels in erosional areas; remainder of site is deflated. Light scatter of tested cobbles and chipped stone debitage, with concentrations in erosional areas of site. Only activity represented is lithic procurement. No temporal components identified; undefined Prehistoric.

Features: None. 
Cultural Materlals Observed/Collected: Tested cobbles and flakes of Potter chert and red coarse-grained quartzite. No collections made.

Shovel Test Data: None.

Assessment/Recommendations: Over $90 \%$ of site appears intact; it lacks subsurface deposits. Site has low research potential and is judged to be not eligible for listing on NRHP. No further work recommended.

\section{GR381}

Location: Ca. $2.0 \mathrm{~km}$ NNW of confluence of Double Mountain Fork and Rocky Creek, and $1.9 \mathrm{~km}$ W of confluence of Double Mountain Fork and Cat Hollow.

Description: Lithic procurement area on upper edge and slope of canyon rim overlooking Gobbler Creek; elevation 2240-2280 ft msl, area $30,000 \mathrm{~m}^{2}$. Lithic scatter surrounding Quaternary gravels exposed in several eroded areas. Lithic procurement only activity represented, although gouges and choppers could indicate vegetal procurement. No temporal components identified; undefined Prehistoric.

Features: None.

Cultural Materials Observed/Collected: Two gouges (one of Potter chert, one of local chert); Potter chert chopper; and tested cobbles, cores, and chipping debris of Potter chert and red coarse-grained quartzite. Two Items collected (see Appendices A and B).

Shovel Test Data: None.

Assessment/Recommendations: Over 90\% of site appears intact; it lacks subsurface deposits. Site has good research potential and is judged to be potentially eligible for listing on NRHP. Recommend controlled collection and mapping.

\section{$41 \mathrm{GR} 383$}

Location: Ca. 2.1 km NNW of confluence of Double Mountain Fork and Rocky Creek, and $2.1 \mathrm{~km}$ W of confluence of Double Mountain Fork and Cat Hollow.

Description: Open campsite on eroded upland margin overlooking Gobbler Creek; elevation 2240-2280 ft $\mathrm{msl}$, area $31,400 \mathrm{~m}^{2}$. Exposures of Quaternary gravels on eroded lower part of site; higher part retains deep eolian sands. Lithic scatter with several clusters of burned rocks on surface and in banks of road cut. Camping area with some plant processing taking place. Disturbed by road cut, surface collection, and pipeline running across surface of site. Temporal component is Late Prehistoric.

Features: Series of burned sandstone lenses and chipping debris ca. $30 \mathrm{~cm}$ below ground surface in cutbank of ditch along road could be either repeatedly used cooking area or burned rock midden. Part of feature severely damaged by road cut. Three diffuse 
clusters ca. $1.5 \mathrm{~m}$ in diameter of burned Potter chert and sandstone fragments found in higher area of site. Exposed by deflation of sand deposits, these appear to be intact.

Cultural Materials Observed/Collected: Arrow point tip (Edwards chert); seven manos (sandstone and quartzite); two gouges (Potter chert); scraper (Edwards chert); chipping debris of Potter chert, Edwards chert, and Tecovas jasper; and fragments of burned sandstone and Potter chert. Two items collected (see Appendices A and B).

Shovel Test Data: One negative shovel test on higher part of site indicated soil depth of at least $1 \mathrm{~m}$.

Assessment/Recommendations: Over $75 \%$ of site appears intact; it contains subsurface deposits, features, and exotics. Site has excellent research potential and is judged to be potentially eligible for listing on NRHP. Recommend controlled collection, mapping, and testing.

\section{GR384}

Location: Ca. $1.6 \mathrm{~km}$ SSW of confluence of Double Mountain Fork and Grape Creek, and $1.1 \mathrm{~km}$ ENE of confluence of Double Mountain Fork and Little Grape Creek.

Description: Open campsite on top of large, low upland rise in area between Double Mountain Fork, Grape Creek, and Little Grape Creek; elevation $2300 \mathrm{ft}$ msl, area $3750 \mathrm{~m}^{2}$. Very sparse lithic scatter. Site could be campsite which has been disturbed by brush clearing and possibly plowing. No temporal components identified; undefined Prehistoric.

Features: Three 1-m-diameter scatters of burned sandstone.

Cultural Materials Observed/Collected: Quartzite gouge, flakes of Edwards chert and Potter chert, and scattered fragments of burned sandstone. One item collected (see Appendices $\mathrm{A}$ and $\mathrm{B})$.

Shovel Test Data: Two negative shovel tests found soil depth of ca. 55-60 cm.

Assessment/Recommendations: Less than $10 \%$ of site appears intact; it lacks subsurface deposits. Site has no research potential and is judged to be not eligible for listing on NRHP. No further work recommended.

\section{GR385}

Location: Ca. $1.5 \mathrm{~km}$ WNW of confluence of Double Mountain Fork and Rocky Creek, and $1.8 \mathrm{~km}$ WSW of confluence of Double Mountain Fork and Gobbler Creek.

Description: Lithic procurement area/open campsite on eroding upland ridge inside large bend of Double Mountain Fork; elevation 2240-2260 ft msl, area 45,000 $\mathrm{m}^{2}$. Lower part of ridge near river is extremely eroded; rest of site is deflating but still has considerable deposit of eolian sands. Sparse scatter of chipped and ground stone tools, tested 
cobbles, debitage, and fragments of burned rocks. Most debitage found in erosional areas on west edge of site. Many burned rocks, as well as possible metate, found in shallow road cut on east edge of site. Area west of road in main part of site has been bladed. Limited lithic procurement, with some camping possibly taking place. No temporal components identifled; undefined Prehistoric.

Features: None.

Cultural Materials Observed/Collected: Scraper; possible sandstone metate; flakes of Edwards chert, Potter chert, and red coarse-grained quartzite; and fragments of burned sandstone. No collections made.

Shovel Test Data: One negative shovel test found solls over $1 \mathrm{~m}$ in deep.

Assessment/Recommendations: Over 90\% of site appears intact; it lacks subsurface deposits. Site has moderate research potential and is judged to be potentially eligible for listing on NRHP. Recommend mapping and testing.

\section{GR386}

Location: Ca. $2.3 \mathrm{~km} \mathrm{NE}$ of confluence of Double Mountain Fork and Red Branch, and 6.8 km ESE of U.S. Highway 84 bridge over Double Mountain Fork.

Description: Lithic procurement area/open campsite on erosional remnant terrace just below edge of upland margin; elevation 2260-2300 ft msl, area 25,000 $\mathrm{m}^{2}$. Serles of bedrock "pans" with small remnant soll deposits. Lithic scatter including burned rock fragments with one area of slight concentration and one distinct burned rock feature. Cultural materials concentrated in eroded pan areas through erosion. Burned rock scatter probably represents redeposited features, indicating that site was used for camping or cooking. Also good evidence for lithic procurement. No temporal components Identified; undefined Prehistoric.

Features: Only distinct feature is $\mathrm{ca}$. 70-cm-diameter cluster of burned sandstone fragments eroding out of edge of soll remnant.

Cultural Materials Observed/Collected: Two scrapers of coarse-grained quartzite; cores, tested cobbles, and chipping debris of Potter chert, coarse-grained quartzite, and opalized wood. Burned fragments of Potter chert and sandstone. No collections made.

Shovel Test Data: Two negative shovel tests in areas of residual soil deposits found 10-20 cm of solls.

Assessment/Recommendations: Over $50 \%$ of site appears intact; it contains features but may lack subsurface deposits. Site has moderate research potential and is judged to be potentially eligible for listing on NRHP. Recommend controlled collection and mapping. 
Location: Ca. $2.7 \mathrm{~km} \mathrm{NE}$ of U.S. Highway 84 bridge over Sand Creek, and $0.3 \mathrm{~km}$ SSW of confluence of Double Mountain Fork and Red Branch.

Description: Lithic procurement area/open campsite at base of mesa between two channels at mouth of Red Branch; elevation $2240 \mathrm{ft} \mathrm{msl}$, area 37,500 $\mathrm{m}^{2}$. Cultural materials on erosional remnant terrace and upper alluvial terrace. First recorded by GRC in 1982, who reported surface scatter of dart and arrow points, ground and chipped stone tools, and debitage. GRC also reported two bedrock mortars. Current investigations verified observations of GRC and also found small burned rock clusters, scattered burned rocks, cores, and tested cobbles. Most cultural materials found on erosional terrace, with only small amount of debitage on alluvial terrace. No evidence of surface collection, but GRC reported previous private collections from site. Other disturbances noted are erosion and deflation. Main activities represented are camping and plant processing, with some lithic procurement. Temporal components are undefined Archaic/Late Prehistoric.

Features: Fourteen small clusters of burned sandstone. One large dense burned rock scatter composed of several small disturbed clusters of burned sandstone. Three mortar holes: largest is $30 \mathrm{~cm}$ long, $15.5 \mathrm{~cm}$ wide, and $19 \mathrm{~cm}$ deep; next largest is $25 \mathrm{~cm} 1$ long, 14 $\mathrm{cm}$ wide, and $11 \mathrm{~cm}$ deep; smallest is $15 \mathrm{~cm}$ long, $10 \mathrm{~cm}$ wide, and $2 \mathrm{~cm}$ deep, and apparently was in early stage of use.

Cultural Materials Observed/Collected: Biface, gouge, scrapers, choppers, manos, cores, tested cobbles, and debitage. Raw materials are Potter chert, Edwards chert, local chert, and coarse-grained quartzite, with most manos made of sandstone. Fragments of burned Potter chert. Elght items collected (see Appendices A and B).

Shovel Test Data: Two shovel tests excavated; one positive. Positive test on erosional remnant terrace found cultural materials to $\mathrm{ca} .20 \mathrm{~cm}$ and had soil depth of ca. $40 \mathrm{~cm}$. Negative test on alluvial terrace found soils to at least $80 \mathrm{~cm}$.

Assessment/Recommendations: Over $75 \%$ of site appears intact; it contains subsurface deposits and features. Site has excellent research potential and is judged to be potentially eligible for listing on NRHP. Recommend controlled collection, mapping, and testing.

\section{GR390}

Location: Ca. $2.5 \mathrm{~km}$ NNW of confluence of Double Mountain Fork and Rocky Creek, and $2.0 \mathrm{~km}$ WNW of confluence of Double Mountain Fork and Cat Hollow.

Description: Open campsite/rock art site on erosional remnant terrace overlooking Gobbler Creek; elevation 2240-2280 ft $\mathrm{msl}$, area 20,000 $\mathrm{m}^{2}$. Site is deflated and has exposed gravel and bedrock; cut by two drainages. First reported by Aaron Riggs in 1966 as part of Reed Shelter Site (41GR54). Riggs reported pictograph on underside of bedrock overhang and bedrock mortar holes across creek from Reed Shelter; also cultural materials on terrace above mortar holes. Rerecorded in 1982 by GRC, who confirmed observations of 
Riggs and described artifact scatter as containing tested cobbles, hammerstones, chipped stone tools, debitage, and burned rock features. Current investigations confirmed previous observations but found more burned rock features than reported by GRC. Site has been disturbed by well pad, oilfield equipment, pipelines, and large sludge pit. It apparently is camping and plant processing area, with some incidental lithic procurement. Nature of association of rock art with rest of site is unknown at present. Temporal component is Late Prehistoric.

Features: Most of numerous burned rock features on site are within large concentration ca. $35 \mathrm{~m}$ in diameter. Features are ca. 1-2 $\mathrm{m}$ in diameter made of burned sandstone fragments with some burned Potter chert. Ten mortar holes are reported on the lower terrace; they range in size from 3 inches long, 2.5 inches wide, and 0.5 inches deep to 14 Inches long, 10.5 inches wide, and 6 inches deep (Riggs 1966:56). Only four definite mortar holes could be relocated.

Rock art consists of pictograph panel (see Fig. 36a) on ceiling of small overhang shelter overlooking creek. Panel is ca. $48 \mathrm{~cm}$ wide and $53 \mathrm{~cm}$ tall and contains human figure and circular element. Human figure is ca. $48 \mathrm{~cm}$ long and ca. $24 \mathrm{~cm}$ wide, drawn in a reddish pigment ("vermillion" according to Riggs); depicts head, arm, long curved torso, two legs bent outward at knees, and one foot. Circular figure is ca. $25 \mathrm{~cm}$ in diameter with cruclform figure in center. Circle is painted with "maroon" pigment, cruciform with "orange" pigment. Perpendicular lines are ca. $17 \mathrm{~cm}$ long and have small arcs at ends ca. 7 $\mathrm{cm}$ long with curvature matching surrounding circle. Rock art elements described by Riggs but not seen during current investigations are two spots of vermillion pigment and 5-cm vermillion circle below foot of human figure (Riggs 1966:51).

Cultural Materials Observed/Collected: Potter chert choppers and hammerstones; debitage of Potter chert, Edwards chert, and coarse-grained quartzite; and fragments of burned sandstone and Potter chert. In addition, GRC reported tested cobbles, petrified wood biface, and Young and Scallorn arrow points which were collected by private individual. Nine items collected (see Appendices A and B).

Shovel Test Data: One shovel test yielded cultural materials to ca. $40 \mathrm{~cm}$ and soils to $58 \mathrm{~cm}$.

Assessment/Recommendations: Over 50\% of artifact scatter appears intact; it contains subsurface deposits and features. Over 90\% of rock art appears intact. Both components have excellent research potential and are judged to be potentially eligible for listing on NRHP. Recommend controlled collection, mapping, and testing of open campsite and detailed recording of rock art (see Table 37 ).

\section{GR393}

Location: Ca. 2.4 km NNE of confluence of Double Mountain Fork and Rocky Creek, and $3.5 \mathrm{~km}$ WNW of confluence of Double Mountain Fork and Little Grape Creek.

Description: Open campsite on small upland ridge and erosional remnant bench overlooking Cat Hollow; elevation 2240-2290 ft msl, area 21,875 $\mathrm{m}^{2}$. Area slightly deflated but still contains eolian deposits. First recorded in 1982 by GRC, who reported lithic scatter 
of tools, tested cobbles, and debitage and noted evidence of surface collection. Current investigations found more extensive site than reported by GRC. Artifact scatter includes chipped stone tools, debitage, and burned rock clusters. Two areas of concentration, one on upland ridge and one on erosional remnant bench below. Upper concentration is smaller and somewhat less dense; both concentrations have features and cultural materials exposed along erosional edges of landform. Numerous burned rock scatters and chipped stone tools indicate camping activities with resource processing. Tested cobbles noted in 1982 suggest lithic procurement in immediate vicinity, if not on site. Component noted is undefined Archaic.

Features: Four concentrations of burned rocks; one is intact feature, while other three probably are eroded remains of features. Definite feature is ca. 1.5-m-diameter cluster of burned sandstone fragments which contains mano, quartzite chopper, hammerstone, burned fragments of Potter chert, and debitage. Remaining concentrations are also composed of burned sandstone fragments, one also containing fragments of limestone. They are ca. 1 $\mathrm{m}$ in diameter and have chipping debris either in or near scatter.

Cultural Materials Observed/Collected: Scrapers; choppers; gouges; mano; dart point fragment (untyped); debitage; burned fragments of sandstone, Potter chert, and limestone. Raw material types represented by tools and debitage are Potter chert, Edwards chert, coarse-grained quartzite, and silicified wood. Eleven items collected (see Appendices A and $\mathrm{B}$ ).

Shovel Test Data: One negative shovel test on erosional bench found soil depth of ca. $45 \mathrm{~cm}$.

Assessment/Recommendations: Over $90 \%$ of site appears intact; it contains features but may lack subsurface deposits. Site has good research potential and is judged to be potentially eligible for listing on NRHP. Recommend controlled collection, mapping, and testing.

\section{$\underline{41 G R 395}$}

Location: Ca. $1.1 \mathrm{~km}$ WSW of confluence of Double Mountain Fork and Cat Hollow, and $1.7 \mathrm{~km} \mathrm{~N}$ of confluence of Double Mountain Fork and Rocky Creek.

Description: Lithic procurement area in scoured-out valley of Gobbler Creek on erosional remnant terrace; elevation 2240-2280 ft msl, area 225,000 $\mathrm{m}^{2}$. Terrace has little soil, with bedrock exposures and Quaternary gravel deposits. First recorded by GRC in 1982 as lithic procurement area containing scatter of tested cobbles and some retouched flakes. Current investigations found site larger than reported in 1982. Diffuse scatter of tested cobbles and a few flakes is concentrated in areas where Quaternary gravels are numerous. Lithic procurement area with no other activities represented. No temporal components identified; undefined Prehistoric.

Features: None.

Cultural Materials Observed/Collected: Tested cobbles and flakes of Potter chert and red coarse-grained quartzite. No collections made. 
Shovel Test Data: None.

Assessment/Recommendations: Less than $50 \%$ of site appears intact; it lacks subsurface deposits. Site has low research potential and is judged to be not eligible for listing on NRHP. No further work recommended.

\section{GR396}

Location: Ca. $2.3 \mathrm{~km}$ NNW of confluence of Double Mountain Fork and Rocky Creek, and $1.9 \mathrm{~km}$ WNW of confluence of Double Mountain Fork and Cat Hollow.

Description: Lithic procurement area/open campsite on upland terrace above Reed Shelter (41GR54), overlooking Gobbler Creek; elevation 2260-2300 ft msl, area $70,000 \mathrm{~m}^{2}$. Substantial deposits of eolian sands over most of site, except near drainages. Quaternary gravels found in west part of site on surface. First reported by Emmett Shedd. Recorded in 1982 by $\mathrm{GRC}_{\text {, }}$ who described lithic procurement area with dart point, scraper, tested cobbles, and debitage. Current investigations found site more extensive than recorded in 1982. Initially, west part of site was considered to be separate, but two areas are continuous and were recorded as one site. Western part of site has wider variety of cultural materials, including ceramics, arrow point, chipped and ground stone tools, cores, tested cobbles, debitage, mussel shell fragments, and burned rock features. Near center of site, eroded cutbanks along dirt road and in small drainage have exposed burned rock features. Site is extensive lithic procurement area with substantial camping. Nature of association with 41GR54 not known. Components identifled are Archaic and Late Prehistoric.

Features: Burned rock features include several burned rock clusters and one burned rock midden. Burned rock clusters in area of small drainage are ca. 75-cm-diameter hearths of burned sandstone fragments eroding out of eolian deposits. Midden found in cutbank of road is ca. $2 \mathrm{~m}$ in diameter and is composed of burned sandstone, mussel shell fragments, mano, and debitage.

Cultural Materials Observed/Collected: El Paso Polychrome ceramic sherd, Fresno arrow point fragment, bifaces, manos, choppers, cores, tested cobbles, chipping debris, burned rock fragments (sandstone and Potter chert), and mussel shell fragments. Lithic materials are Potter chert, Edwards chert, Tecovas jasper, and coarse-grained quartzite. Twelve items collected (see Appendices A and B).

Shovel Test Data: One shovel test in vicinity of burned rock midden contained cultural materials and soils to $\mathrm{ca} .60 \mathrm{~cm}$.

Assessment/Recommendations: Over 75\% of site appears intact; it contains subsurface deposits, features, ceramics, and exotics. Site has excellent research potential and is judged to be potentially eligible for listing on NRHP. Recommend controlled collection, mapping, and testing.

\section{$41 \mathrm{GR} 403$}

Location: Ca. $1.1 \mathrm{~km}$ NNE of confluence of Double Mountain Fork and Rocky Creek, and $4.3 \mathrm{~km}$ WSW of confluence of Double Mountain Fork and Little Grape Creek. 
Description: Lithic procurement area/open campsite on large, deflated bedrock terrace above confluence of Double Mountain Fork and Gobbler Creek; elevation 2230-2240 ft msl, area $19,500 \mathrm{~m}^{2}$. Very sparse scatter of tested cobbles and debitage, with concentration of burned rocks in erosional area near center of site. Small lithic procurement area scattered by erosion, with burned rock concentration representing remains of camping feature. No temporal components identified; undefined Prehistoric.

Features: Burned rock concentration in erosional drainage measures ca. $15 \mathrm{x} 5 \mathrm{~m}$.

Cultural Materials Observed/Collected: Ca. 20 tested cobbles, debitage, and ca. 20 fragments of burned Potter chert. No collections made.

Shovel Test Data: None.

Assessment/Recommendations: Over $75 \%$ of site appears intact; it contains a displaced feature and lacks subsurface deposits. Site has no research potential and is judged to be not eligible for listing on NRHP. No further work recommended.

\section{$\underline{41 G R 405}$}

Location: Ca. $5.2 \mathrm{~km}$ SW of intersection of the Garza/Kent county line and Double Mountain Fork, and $2.4 \mathrm{~km}$ W of confluence of Double Mountain Fork and Little Grape Creek.

Description: Open campsite in area of road cut through lower alluvial terrace of Double Mountain Fork; elevation $2180 \mathrm{ft} \mathrm{msl}$, area $375 \mathrm{~m}^{2}$. Two clusters of sandstone cobbles and debitage scatter. One cluster was found in cutbank ca. $1 \mathrm{~m}$ below surface, with debitage eroding from cutbank above it at ca. $40 \mathrm{~cm}$ below surface. Site appears to be remains of small campsite. Road cut and erosion have destroyed much of site. No temporal components identified; undefined Prehistoric.

Features: Two clusters of unburned sandstone. One within bank of road cut at depth of $1 \mathrm{~m}$ is ca. $25 \mathrm{~cm}$ long and $10 \mathrm{~cm}$ thick, composed of two unburned sandstone slabs. Other cluster of sandstone cobbles was found away from road cut and consists of a few unburned sandstone pieces scattered on side of erosional gully. No artifacts associated. Features could be natural.

Cultural Materials Observed/Collected: Worked stream gravel, flake of local chert, and several thinning flakes of Edwards chert. No collections made.

Shovel Test Data: Three negative shovel tests excavated, two just above road cut and one in less-disturbed area of terrace. Tests near road found soils over $120 \mathrm{~cm}$ deep, while test away from road cut found ca. $60 \mathrm{~cm}$ of soil over bedrock.

Assessment/Recommendations: Over $50 \%$ of site appears intact; it contains features of unknown origin and sparse cultural materials. Site has no research potential and is judged to be not eligible for listing on NRHP. No further work recommended. 
Location: Ca. $1.5 \mathrm{~km}$ NW of confluence of Double Mountain Fork and Rocky Creek, and $1.6 \mathrm{~km}$ WSW of confluence of Double Mountain Fork and Gobbler Creek.

Description: Lithic procurement area/open campsite on eroded bench below upland margin on north side of Double Mountain Fork adjacent to small drainage; elevation 2220$2230 \mathrm{ft} \mathrm{msl}$, area $15,000 \mathrm{~m}^{2}$. Sandstone bedrock exposed, but some eollan sand still present on site. Very sparse scatter of chipped stone tools, tested cobbles, debitage, and burned rock fragments; 15-m-diameter concentration of cultural materials at one end of site. Burned rocks indicate use as campsite; debitage indicates 1ithic procurement activities. No temporal components identified; undefined Prehistoric.

Features: None.

Cultural Materials Observed/Collected: Biface fragment (possible dart point), scrapers, chipping debris of Potter chert, Edwards chert, red coarse-grained quartzite, and local chert. Burned fragments of Potter chert and limestone. Two items collected (see Appendices $A$ and $B$ ).

Shovel Test Data: One shovel test yielded cultural materlals to ca. $20 \mathrm{~cm}$ and found soils to ca. $44 \mathrm{~cm}$.

Assessment/Recommendations: Over 50\% of site appears intact; it contains subsurface deposits. Site has moderate research potential and is judged to be potentially eligible for listing on NRHP. Recommend controlled collection, mapping, and testing.

\section{$\underline{41 G R 407}$}

Location: Ca. $1.5 \mathrm{~km} \mathrm{NW}$ of confluence of Double Mountain Fork and Rocky Creek, and $1.6 \mathrm{~km}$ WSW of confluence of Double Mountain Fork and Gobbler Creek.

Description: Lithic procurement area/open campsite on upland margin and erosional remnant terrace below 1t; elevation 2220-2240 ft ms1, area 11,250 $\mathrm{m}^{2}$. Scatter of chipped stone and burned rock fragments. Burned rocks probably result from camping or related activities; however, primary activity at site was lithic procurement. Component identified is Late Prehistoric.

Features: None.

Cultural Materials observed/Collected: Arrow point of moss agate; tested cobbles and debitage of chalcedony, Edwards chert, Potter chert, coarse-grained quartzite, and local chert; and fragments of burned Potter chert and limestone. Five items collected (see Appendices $\mathrm{A}$ and $\mathrm{B}$ ).

Shovel Test Data: One shovel test found debitage and solls to ca. $38 \mathrm{~cm}$. 
Assessment/Recommendations: Less than $50 \%$ of site appears intact; it contains subsurface deposits. Site has good research potential and is judged to be potentially eligible for listing on NRHP. Recommend controlled collection, mapping, and testing.

\section{$41 \mathrm{GR} 408$}

Location: Ca. $1.1 \mathrm{~km}$ NNE of confluence of Double Mountain Fork and Rocky Creek, and $4.0 \mathrm{~km}$ WSW of confluence of Double Mountain Fork and Little Grape Creek.

Description: Lithic procurement area on eroded upland margin rim in outcrop of Quaternary gravels above Double Mountain Fork; elevation 2220-2280 ft msl, area 37,500 m². Scatter of lithic artifacts. Lithic procurement area with some tool manufacture. No temporal components identified; undefined Prehistoric.

Features: None.

Cultural Materials Observed/Collected: Gouge of Potter chert, few cores, tested cobbles, and debitage of Potter chert and coarse-grained quartzite. One item collected (see Appendices $A$ and $B$ ).

Shovel Test Data: None.

Assessment/Recommendations: Over $75 \%$ of site appears intact; it lacks subsurface deposits. Site has good research potential and is judged to be potentlally eligible for listing on NRHP. Recommend controlled collection and mapping.

\section{GR409}

Location: Ca. $0.2 \mathrm{~km}$ NNW of confluence of Double Mountain Fork and Rocky Creek, and $4.7 \mathrm{~km}$ WSW of confluence of Double Mountain Fork and Little Grape Creek.

Description: Rock art site ca. $3 \mathrm{~m}$ below canyon rim on vertical face of soft sandstone above Double Mountain Fork; elevation $2230 \mathrm{ft} \mathrm{msl}$, area less than $1 \mathrm{~m}^{2}$. Single petroglyph carved into sandstone (see Fig. 36b). Very little shelter provided by bluff face; no evidence of habitation (i.e., charcoal, debitage, etc.) in shelter area or on steep bluff slope down to river below. Just across Double Mountain Fork from Dorward Ranch Site (41GR51), an Historic Indian rock art site; the two sites may be related. No temporal components identified; undefined Prehistoric.

Features: Petroglyph is $14 \mathrm{~cm}$ tall and $10 \mathrm{~cm}$ wide. Depicts human figure with arms outstretched and bent at the elbows; torso made of two parallel diagonal lines with perpendicular line connecting them at top. Head composed of single curved line connecting upper two corners of torso, where arms also originate. Near bottom of figure, single faint line slants downward toward inside of torso.

Cultural Materials Observed/Collected: None. 
Shovel Test Data: None.

Assessment/Recommendations: Over $75 \%$ of site appears intact; it preserves features but lacks subsurface deposits. Site has excellent research potential and is judged to be potentially eligible for listing on NRHP. Recommend detailed recording (see Table 37 ).

\section{$41 \mathrm{GR} 410$}

Location: Ca. $0.2 \mathrm{~km} \mathrm{~N}$ of confluence of the Double Mountain Fork and Rocky Creek, and $4.8 \mathrm{~km}$ WSW of confluence of the Double Mountain Fork and Little Grape Creek.

Description: Rock art site in bluff overhang at end of point overlooking inside of bend in Double Mountain Fork; elevation $2240 \mathrm{ft} \mathrm{msl}$, area less than $1 \mathrm{~m}^{2}$. Overhang roofed by dark ferruginous sandstone overlying lighter and softer sandstone eroded by wind to form shallow overhang. Single rock art panel (see Fig. 36c) engraved into face of dark sandstone roof. No evidence of occupation inside shelter, which is shallow and has low celling. Some historic and recent graffiti in vicinity, but petroglyphs remain undamaged. No temporal components identified; undefined Prehistoric.

Features: Single panel of rock art $54 \mathrm{~cm}$ long and $25 \mathrm{~cm}$ tall contains three petroglyphic elements. Two depict animal figures (possibly deer). One is $33 \mathrm{~cm}$ long and $15 \mathrm{~cm}$ tall; other is $12 \mathrm{~cm}$ long and $11 \mathrm{~cm}$ tall. The larger animal has short branching horns and short curving tail. Back end of smaller animal is just below and to right of larger animal's foreleg, directly under head and neck of larger animal. Third element is ca. 14 $\mathrm{cm}$ to right of larger animal figure. This geometric element is two diagonal lines which converge near lower ends, with upper ends tilting to right.

Cultural Materials Observed/Collected: None.

Shovel Test Data: None.

Assessment/Recommendations: Over $50 \%$ of site appears intact; it preserves features but lacks subsurface deposits. Site has excellent research potential and is judged to be potentially eligible for listing on NRHP. Recommend detalled recording (see Table 37).

\section{$41 \mathrm{GR} 417$}

Location: Ca. $0.8 \mathrm{~km}$ NNE of confluence of Double Mountain Fork and Rocky Creek, and $4.1 \mathrm{~km}$ WSW of confluence of Double Mountain Fork and Little Grape Creek.

Description: Lithic procurement area on canyon rim overlooking Double Mountain Fork; elevation 2280-2300 ft msl, area 25,000 m². Quaternary gravels exposed along eroded canyon rim for $500 \mathrm{~m}$. Sparse scatter of tested cobbles, debitage, and burned rocks. Lithic procurement area used intermittently. No temporal components identified; undefined Prehistoric.

Features: None. 
Cultural Materials Observed/Collected: Tested cobbles and debitage of Potter chert, local chert, and red coarse-grained quartzite; three fragments of burned Potter chert. No collections made.

Shovel Test Data: None.

Assessment/Recommendations: Over $75 \%$ of site appears intact; it lacks subsurface deposits. Site has good research potential and is judged to be potentially eligible for listing on NRHP. Recommend controlled collection and mapping.

$\underline{41 G R 420}$

Location: Ca. $0.2 \mathrm{~km}$ E of confluence of Double Mountain Fork and Rocky Creek, and 2.1 $\mathrm{km}$ SSW of confluence of Double Mountain Fork and Cat Hollow.

Description: Rock art site in overhang shelter on bluff overlooking Double Mountain Fork; elevation $2200 \mathrm{ft} \mathrm{msl,} \mathrm{area} 50 \mathrm{~m}^{2}$. Shelter is ca. $10 \mathrm{~m}$ long and $5 \mathrm{~m}$ deep; floor covered with deposit of eolian sand and sand fallen from roof. Single element of rock art (see Fig. 32d) on natural sandstone column that spans height of shelter. Only evidence of occupation in shelter is recent camping, indicated by fresh charcoal, Boy Scout knife, and recent graffiti. Site could be prehistoric or historic aboriginal but is classified as undefined Prehistoric.

Features: Single petroglyph $10 \mathrm{~cm}$ tall and $5 \mathrm{~cm}$ wide consists of four straight lines ca. $5 \mathrm{~cm}$ long arranged around a central triangle $7 \mathrm{~cm}$ tall and $3.5 \mathrm{~cm}$ wide. Triangle points upward and is bisected by vertical line with small circle at upper end; two short lines drawn from center of bottom of triangle.

Cultural Materials Observed/Collected: None.

Shovel Test Data: One negative shovel test found that sands on shelter floor are ca. $20 \mathrm{~cm}$ deep.

Assessment/Recommendations: Less than 50\% of site appears intact; it preserves features but lacks subsurface deposits. Site has excellent research potential and is judged to be potentially eligible for listing on NRHP. Recommend detailed recording (see Table 37).

$\underline{41 G R 422}$

Location: Ca. $0.4 \mathrm{~km}$ ESE of confluence of Double Mountain Fork and Rocky Creek, and $2.1 \mathrm{~km}$ SSW of confluence of Double Mountain Fork and Cat Hollow.

Description: Open campsite in bottom of upland canyon above Double Mountain Fork floodplain; elevation 2220-2240 ft msl, area 24,000 $\mathrm{m}^{2}$. Floor of canyon covered with deposits of fine sand. Dense lithic scatter with few tested cobbles and three concentrations of clusters of burned sandstone, some large and dense enough to resemble burned rock 
middens. Number of features, along with number of manos, indicates site was used for cooking or processing of vegetal resources, with camping also. No temporal components identifled; undefined Prehistoric.

Features: Numerous small clusters of burned sandstone fragments, most ca. $50-100 \mathrm{~cm}$ in diameter. At least two larger clusters of sandstone slabs and fragments which appear to be middens ca. 1.5-2 $\mathrm{m}$ in diameter and 25-30 cm high at center. General scatters of burned sandstone fragments may represent additional features scattered by erosion.

Cultural Materials Observed/Collected: Hammerstones, manos, and debitage of Edwards chert, coarse-grained quartzite, and Potter chert; fragments of burned sandstone; and few tested cobbles of Potter chert. Five items collected (see Appendices A and B).

Shovel Test Data: Two shovel tests excavated, one positive. Negative test found soil depth of ca. $35 \mathrm{~cm}$; positive test yielded burned rocks and debitage to $20-40 \mathrm{~cm}$ and soil to ca. $60 \mathrm{~cm}$.

Assessment/Recommendations: Over 75\% of site appears intact; it contains features and subsurface deposits. Site has excellent research potential and is judged to be potentially eligible for listing on NRHP. Recommend controlled collection, mapping, and testing.

\subsection{GR423}

Location: Ca. $0.2 \mathrm{~km}$ SSE of confluence of Double Mountain Fork and Rocky Creek, and $5.0 \mathrm{~km}$ WSW of confluence of Double Mountain Fork and Little Grape Creek.

Description: Rock art site on vertical sandstone exposure on bluff face overlooking confluence of Double Mountain Fork and Rocky Creek; elevation $2220 \mathrm{ft} \mathrm{msl}$, area $1 \mathrm{~m}^{2}$. Single panel of aboriginal rock art (see Fig. 37a) carved into sandstone face, sheltered somewhat by short rock ledge extending ca. $75 \mathrm{~cm}$ from bluff. Shelf below face is ca. $3 \mathrm{~m}$ wide and has small amount of colluvium at outer edge. No cultural deposits on shelf; no other evidence of cultural activity found. No temporal components identified; undefined Prehistoric.

Features: Single panel of rock art ca. $65 \mathrm{~cm}$ tall and ca. $75 \mathrm{~cm}$ wide. Two anthropomorphic figures drawn in red plgment with engraved outline. Each figure composed of rectangular torso ca. $41 \mathrm{~cm}$ long and $8 \mathrm{~cm}$ wide. Legs depicted by two narrow triangles at bottom corners of each figure; these are $\mathrm{ca} .9 \mathrm{~cm}$ long and $2 \mathrm{~cm}$ wide at top where they join body. One figure has small oval feet $\mathrm{ca} .3 \mathrm{~cm}$ long and $1 \mathrm{~cm}$ wide, and shows vestiges of round head with rectangular "cap." Head sits squarely upon top of rectangular torso and is ca. $9 \mathrm{~cm}$ in diameter; "cap" is ca. $6 \mathrm{~cm}$ wide and $2 \mathrm{~cm}$ tall. Figure also has two small arms bent at elbows drawn by faint engraved lines from upper corners of torso. Other figure very similar to first, except that torso is slightly curved, it has no feet or arms, and head is eroded to point of being virtually indistinguishable. Small triangular "cap" $8 \mathrm{~cm}$ long and $3 \mathrm{~cm}$ high visible ca. $6 \mathrm{~cm}$ above torso. Vertical line along left side of this figure begins ca. $10 \mathrm{~cm}$ below top of torso and extends $16 \mathrm{~cm}$ downward; could be either natural line in sandstone or representation of an arm.

Cultural Materials Observed/Collected: None. 
Shovel Test Data: None.

Assessment/Recommendations: Over $90 \%$ of site appears intact; it preserves features but lacks subsurface deposits. Site has excellent research potential and is judged to be potentially eligible for listing on NRHP. Recommend detailed recording (see Table 37).

$\underline{41 G R 424}$

Location: Ca. $0.3 \mathrm{~km}$ SSE of confluence of Double Mountain Fork and Rocky Creek, and $2.4 \mathrm{~km}$ SSW of confluence of Double Mountain Fork and Cat Hollow.

Description: Rock art site on bluff overlooking Rocky Creek in shelter formed by erosion of softer sandstone below stratum of darker, harder ferruginous sandstone; elevation $2210 \mathrm{ft} \mathrm{msl}$, area $40 \mathrm{~m}^{2}$. Shelter is $8 \mathrm{~m}$ long and $5 \mathrm{~m}$ wide, with large pillar of sandstone in front and opening on both ends. Sandstone pillar has numerous holes, one opening into small chamber inside pillar. Low projection like small shelf extends from interior of pillar near opening of shelter. On top of shelf is small panel of rock art with set of grooved lines arranged in shape of triangle (see Fig. 32e). Floor of shelter is covered with deposit of red clayey soil; shovel probes found no indication of cultural deposits. No temporal components identified; undefined Prehistoric.

Features: Single panel of rock art ca. $21 \mathrm{~cm}$ wide and ca. $19 \mathrm{~cm}$ long contains petroglyph composed of seven tally marks of increasing lengths forming triangle. Longest line is $24 \mathrm{~cm}$ long, and shortest is $4 \mathrm{~cm}$ long; all are ca. $1 \mathrm{~cm}$ wide and 2-3 cm apart. Sides of triangle measure 24, 22, and $20 \mathrm{~cm}$. Lines could represent rock art or place used by prehistoric inhabitants of area for sharpening or straightening wooden shafts.

Cultural Materials Observed/Collected: None.

Shovel Test Data: Shovel probes were negative and found clayey soils ca. $12 \mathrm{~cm}$ deep.

Assessment/Recommendations: Over 90\% of site appears intact; it preserves features but lacks subsurface deposits. Site has excellent research potential and is judged to be potentially eligible for listing on NRHP. Recommend detailed recording (see Table 37).

\section{$\underline{41 G R 425}$}

Location: Ca. $0.2 \mathrm{~km}$ SSW of confluence of Double Mountain Fork and Rocky Creek, and $5.0 \mathrm{~km}$ WSW of confluence of Double Mountain Fork and Little Grape Creek.

Description: Open campsite on rocky terrace at base of bluff overlooking Rocky Creek floodplain; elevation $2190 \mathrm{ft} \mathrm{msl}$, area $1575 \mathrm{~m}^{2}$. Large amount of sandstone bedrock exposed on terrace, but few cobbles of chippable stone are present. Scatter of chipped stone tools including dart point base, debitage, and few burned rocks, with cluster of sandstone cobbles and possible mortar hole. Site was used for camping and nonlithic procurement/processing, with some tool manufacture or refurbishing. Not enough chippable gravels on site for lithic procurement to have been significant activity. Disturbed slightly by a bulldozer 
cut through south edge of site, which probably explains the bedrock exposure in this area of site. Temporal component Identified is late Archaic.

Features: Two features; one is a ca. 1-m-diameter cluster of slightly burned sandstone fragments in area of artifact concentration. Other feature is small, shallow depression in sandstone bedrock which is possible mortar hole but could be result of natural weathering and erosion.

Cultural Materlals Observed/Collected: Basal fragment of a corner-notched dart point, crude biface fragment, and small amount of debitage, all of local chert. Two items collected (see Appendices A and B).

Shovel Test Data: Two shovel tests excavated, one positive. Negative test found soil depth of ca. $68 \mathrm{~cm}$. Positive test yielded debitage at $5 \mathrm{~cm}$ below surface and found soils to at least $90 \mathrm{~cm}$.

Assessment/Recommendations: Over $50 \%$ of site appears intact; it contains features and may have subsurface deposits. Site has unknown research potential but is judged to be potentially ellgible for listing on NRHP. Recommend controlled collection, mapping, and testing.

\section{$\underline{41 \mathrm{GR} 426}$}

Location: Ca. $0.5 \mathrm{~km}$ SSE of confluence of Double Mountain Fork and Rocky Creek, and $5.1 \mathrm{~km}$ WSW of confluence of Double Mountain Fork and Little Grape Creek.

Description: Rock art site on lower bluff overlooking Rocky Creek where sandstone face has eroded to form slightly recessed area beneath harder sandstone forming overhang ca. $75 \mathrm{~cm}$ deep; elevation $2210 \mathrm{ft} \mathrm{msl}$; area less than $1 \mathrm{~m}^{2}$. Single plctograph (see Fig. 37b), with no other evidence of cultural activity. Shallow soil deposit below pictograph indicated no cultural deposits. Undisturbed by historic or recent graffiti but adversely affected by erosion. No temporal components Identified; undefined Prehistoric.

Features: Ca. 14-cm-tall and 12- cm wide pictograph of hand outlined in red pigment. Pigment extends ca. $2-3 \mathrm{~cm}$ beyond edge of handprint.

Cultural Materials Observed/Collected: None.

Shovel Test Data: One negative shovel test in soil beneath pictograph found soil depth of ca. $30 \mathrm{~cm}$.

Assessment/Recommendations: Over $90 \%$ of site appears Intact; it preserves one feature but lacks subsurface deposits. Site has excellent research potential and is judged to be potentially eligible for listing on NRHP. Recommend detailed recording (see Table 37).

\section{GR427}

Location: $\mathrm{Ca}$. $0.6 \mathrm{~km}$ SSE of confluence of Double Mountain Fork and Rocky Creek, and $5.0 \mathrm{~km}$ WSW of confluence of Double Mountain Fork and Little Grape Creek. 
Description: Open campsite in large bowl-like depression eroded into upland margin; elevation 2210-2245 ft msl, area 15,750 $\mathrm{m}^{2}$. Small drainage flows through center of depression, with wide deflated areas on both sides. Lithic scatter with four burned rock features. Single fragment of purple glass found in scatter is not considered to represent historic component of consequence. Artifact scatter is less dense in southern part of site where materials may be buried by eolian deposition. Evidence of surface collection. Campsite with some processing or procurement of vegetal materials and limited lithic procurement. No temporal components identified; undefined Prehistoric.

Features: Four clusters of burned sandstone and limestone, ranging from $60-100 \mathrm{~cm}$ in diameter.

Cultural Materials Observed/Collected: Quartzite mano, utilized and unifacially retouched flakes, hammerstones, cores, chipping debris, and fragments of burned sandstone and limestone. Raw materials are Potter chert, coarse-grained quartzite, Edwards chert, Tecovas jasper, and local chert. Two items collected (see Appendices A and B).

Shovel Test Data: Two negative shovel tests indicated soil depths of 27 and $42 \mathrm{~cm}$.

Assessment/Recommendations: Over $50 \%$ of site appears intact; it contains features but may lack subsurface deposits. Site has moderate research potential and is judged to be potentially eligible for listing on NRHP. Recommend controlled collection, mapping, and testing.

\section{GR429}

Location: Ca. $0.8 \mathrm{~km}$ SSE of confluence of Double Mountain Fork and Rocky Creek, and $5.0 \mathrm{~km}$ WSW of confluence of Double Mountain Fork and Little Grape Creek.

Description: Open campsite on slope above side drainage and on erosional remnant terrace; elevation 2240-2250 ft msl, area $4550 \mathrm{~m}^{2}$. Terrace edged by exposed sandstone bedrock with colluvial and eolian deposits covering surface. Artifact scatter with several small scatters of burned rocks. No clear indication of lithic procurement, but presence of burned rock features and scrapers suggests camping and possibly plant processing. Temporal component is middle Archaic.

Features: Four diffuse scatters of burned sandstone range in size from ca. $3 \times 1.5$ to $5 \times 3 \mathrm{~m}$.

Cultural Materials Observed/Collected: Proximal fragment of untyped stemmed dart point; scrapers; cores; and debitage of Potter chert, Edwards chert, red coarse-grained quartzite, and local chert; and burned fragments of sandstone. Three items were collected (see Appendices $\mathrm{A}$ and $\mathrm{B}$ ).

Shovel Test Data: Two shovel tests excavated, both positive. One yielded a burned rock between 0-20 cm and found soil depth of $30 \mathrm{~cm}$; other ylelded debitage at 0-10 cm and found soils ca. $10 \mathrm{~cm}$ deep.

Assessment/Recommendations: Over $75 \%$ of site appears intact; it contains features and subsurface deposits. Site has unknown research potential but is judged to be potentially eligible for listing on NRHP. Recommend controlled collection, mapping, and testing. 
Location: $\mathrm{Ca} .1 .0 \mathrm{~km}$ SSW of confluence of Double Mountain Fork and Rocky Creek, and $5.5 \mathrm{~km}$ SW of confluence of Double Mountain Fork and Little Grape Creek.

Description: Open campsite on bedrock terrace overlooking floodplain in bend in Rocky Creek; elevation $2220 \mathrm{ft} \mathrm{msl}$, area $325 \mathrm{~m}^{2}$. Very sparse scatter of burned rock fragments and a flake, with single burned rock feature comprising main part of site. Site represents single camping episode. No temporal components identified; undefined Prehistoric.

Features: Rectangular slab-lined hearth measuring ca. $140 \mathrm{~cm}$ long, $130 \mathrm{~cm}$ wide, and 8 $\mathrm{cm}$ deep. Visible on surface as rectangular enclosure of burned sandstone cobbles, but excavation of one-quarter of hearth found bottom paved with slabs of sandstone.

Cultural Materials Observed/Collected: Fragments of burned sandstone, Edwards chert flake. No collections made.

Shovel Test Data: Two shovel tests excavated in terrace; one positive. Negative test found soil depth of ca. $50 \mathrm{~cm}$. Positive test made in feature yielded burned sandstone slabs to ca. 5-8 cm below surface.

Assessment/Recommendations: Over $75 \%$ of site appears intact; it contains a feature and subsurface deposits. Site has moderate research potential and is judged to be potentially eligible for listing on NRHP. Recommend mapping and testing.

\section{$\underline{41 G R 431}$}

Location: Ca. $1.0 \mathrm{~km}$ SSW of confluence of Double Mountain Fork and Rocky Creek, and $5.5 \mathrm{~km}$ SW of confluence of Double Mountain Fork and Little Grape Creek.

Description: Open campsite on erosional remnant terrace overlooking floodplain within large bend in Rocky Creek; elevation 2220-2230 ft msl, area $4000 \mathrm{~m}^{2}$. Area is somewhat eroded and deflated with shallow solls. Very sparse lithic scatter with at least one burned rock feature concentrated in area roughly $8 \mathrm{~m}$ in diameter. Damaged slightly by pipeline construction and natural erosion. Majority of damage is in immediate vicinity of burned rock feature. Site was used for camping, with limited lithic procurement and/or heat-treating of raw materials. No temporal components identified; undefined Prehistoric.

Features: Diffuse cluster of burned sandstone fragments covering area ca. $5 \times 2.5 \mathrm{~m}$. Feature is eroded and deflated and sits directly on exposed bedrock. Any other features which may have been on site have eroded away.

Cultural Materials Observed/Collected: Flakes and tested cobbles of Potter chert; flakes of Edwards chert, local chert, and red coarse-grained quartzite; and fragments of burned sandstone and Potter chert. No collections made.

Shovel Test Data: One negative shovel indicated soil depth of $30 \mathrm{~cm}$. 
Assessment/Recommendations: Over $75 \%$ of site appears intact; it contains a feature but lacks subsurface deposits. Site has no research potential and is judged to be not eligible for listing on NRHP. No further work recommended.

\section{$\underline{41 G R 432}$}

Location: Ca. $0.9 \mathrm{~km}$ SSW of confluence of Double Mountain Fork and Rocky Creek, and $5.2 \mathrm{~km}$ WSW of confluence of Double Mountain Fork and Little Grape Creek.

Description: Open campsite on upland margin and erosional bench above Rocky Creek; elevation $2240 \mathrm{ft} \mathrm{msl}$, area $3600 \mathrm{~m}^{2}$. Lower bench is quite eroded. Dense 11thic scatter with three concentrations of debitage and burned rock feature. Site appears to represent camping area with substantial tool manufacture or refurbishing. Temporal component identified is Late Prehistoric.

Features: One of three flake concentrations is quite small and could be pothunter's cull pile. Other two are larger (ca. $2 \mathrm{~m}$ in diameter and ca. $2 \times 5 \mathrm{~m}$ ) and are probably cultural. One possible burned rock midden composed of burned sandstone fragments measures ca. $4 \times 3 \mathrm{~m}$.

Cultural Materials Observed/Collected: Fragment of Fresno arrow polnt; core and flakes of Potter chert; debitage of Edwards chert, local chert, and red coarse-grained quartzite; bone fragments; and fragments of burned sandstone. One item collected (see Appendices $\mathrm{A}$ and $\mathrm{B}$ ).

Shovel Test Data: Two negative shovel tests indicated soil depths of 10 and $40 \mathrm{~cm}$.

Assessment/Recommendations: Over $75 \%$ of site appears intact; it contains features but may lack subsurface deposits. Site has unknown research potential but is judged to be potentially eligible for listing on NRHP. Recommend controlled collection, mapping, and testing.

\section{GR433}

Location: Ca. $1.6 \mathrm{~km}$ SSW of confluence of Double Mountain Fork and Rocky Creek, and $5.9 \mathrm{~km}$ SW of confluence of Double Mountain Fork and Little Grape Creek.

Description: Open campsite on erosional remnant bench above Rocky Creek floodplain; elevation $2260 \mathrm{ft} \mathrm{msl}$, area $5000 \mathrm{~m}^{2}$. Soils on bench are deflated; Quaternary gravels exposed on surface. Sparse scatter of debitage and two small clusters of burned rocks. Extensively disturbed by erosion. May be campsite. No temporal components identified; undefined Prehistoric.

Features: Two ca. 1-m-diameter clusters of burned sandstone fragments, with possibly burned limestone fragments scattered in adjacent area. Clusters may be remains of hearths. 
Cultural Materials Observed/Collected: Flakes of Potter chert and red coarse-grained quartzite, Edwards chert flake, and fragments of burned sandstone and limestone. No collections made.

Shovel Test Data: None.

Assessment/Recommendations: Less than $25 \%$ of site appears intact; it contains features but lacks subsurface deposits. Site has no research potential and is judged to be not eligible for listing on NRHP. No further work recommended.

\section{$41 \mathrm{GR} 434$}

Location: Ca. $1.5 \mathrm{~km}$ SSW of confluence of Double Mountain Fork and Rocky Creek, and $6.0 \mathrm{~km}$ SW of confluence of Double Mountain Fork and Little Grape Creek.

Description: Lithic procurement area/open campsite on terrace overlooking Rocky Creek floodplain; elevation 2220-2240 ft msl, area $5000 \mathrm{~m}^{2}$. Site area deflated and gravelly, with very little soil. Very sparse lithic scatter. Tested cobbles and debitage indicate some utilization of exposed gravels as lithic source, with burned rocks representing campfires or fires used in heat-treating lithic materials. No temporal components identified; undefined Prehistoric.

Features: None.

Cultural Materials Observed/Collected: Tested cobble of Potter chert; debitage of Potter chert, Edwards chert, and local chert; and burned fragments of sandstone and limestone. No collections made.

Shovel Test Data: None.

Assessment/Recommendations: Less than $50 \%$ of site appears intact; it lacks subsurface deposits. Site has no research potential and is judged to be not eligible for listing on NRHP. No further work recommended.

\section{$\underline{41 G R 435}$}

Location: Ca. $2.0 \mathrm{~km}$ SSW of confluence of Double Mountain Fork and Rocky Creek, and $6.1 \mathrm{~km}$ SW of confluence of Double Mountain Fork and Little Grape Creek.

Description: Open campsite on lower alluvial terrace of small horseshoe-shaped side canyon above Rocky Creek; elevation $2230 \mathrm{ft} \mathrm{msl,} \mathrm{area} 3750 \mathrm{~m}^{2}$. Sparse scatter of debitage, with scraper and two burned rock features. Severely disturbed by deflation and by numerous ollfield roads. Probably used for camping. No temporal components identified; undefined Prehistoric.

Features: Two diffuse, ca. 1-m-diameter clusters of burned sandstone may represent deflated hearths. 
Cultural Materials Observed/Collected: Edwards chert scraper; few flakes of Potter chert, coarse-grained quartzite, and Edwards chert; and scattered fragments of burned sandstone. No collections made.

Shovel Test Data: One negative shovel test indicated soil depth of ca. $30 \mathrm{~cm}$.

Assessment/Recommendations: Less than $50 \%$ of site appears intact; it contains features but lacks subsurface deposits. Site has no research potential and is judged to be not eligible for listing on NRHP. No further work recommended.

\section{$\underline{41 \mathrm{GR} 437}$}

Location: Ca. $1.6 \mathrm{~km}$ SSW of confluence of Double Mountain Fork and Rocky Creek, and $6.0 \mathrm{~km}$ SW of confluence of the Double Mountain Fork and Little Grape Creek.

Description: Rock art site in rockshelter just above base of eroded bluff above Rocky Creek; elevation $2230 \mathrm{ft} \mathrm{msl}$, area ca. $2 \mathrm{~m}^{2}$. Two sheltered areas with rock art panels; one has aboriginal rock art (see Fig. 37c), other has historic inscriptions. No soil deposits in shelter. Sheltered area with aboriginal rock art is ca. $12 \mathrm{~m}$ long and $2 \mathrm{~m}$ deep; rock art is on back wall near top of shelter. Aboriginal rock art is undisturbed by historic inscriptions but somewhat damaged by spalling and erosion. Temporal components are undefined Prehistoric and Historic (see Appendix G for description of historic component).

Features: Three panels of aboriginal rock art; one pictograph panel and two petroglyph panels. Pictograph panel ca. $200 \mathrm{~cm}$ long and $45 \mathrm{~cm}$ tall has two elements drawn in black pigment or charcoal. First is series of 19 near-vertical, parallel tally marks. Fourteen lines are ca. $15 \mathrm{~cm}$ long (give or take $5 \mathrm{~cm}$ ), while two faint lines are ca. $25 \mathrm{~cm}$ long and may be several lines drawn end to end vertically. Remaining three lines are ca. 5 $\mathrm{cm}$ long and are at far left end of series. Element $10 \mathrm{~cm}$ to left of tally marks is group of curved lines $45 \mathrm{~cm}$ tall and $50 \mathrm{~cm}$ wide which could represent bison or other animal.

Two petroglyph are located below pictograph. One is $35 \mathrm{~cm}$ below and to left of zoomorphic pictograph and is narrow, cross-shaped figure made up of slightly diagonal line $30 \mathrm{~cm}$ long bisected by perpendicular line $15 \mathrm{~cm}$ long. Other petroglyph is $2.5 \mathrm{~m}$ to $\mathrm{right}$ of first petroglyph and consists of two parallel vertical lines $74 \mathrm{~cm}$ apart. One line is $25 \mathrm{~cm}$ long; other is $10 \mathrm{~cm}$ long.

Cultural Materials Observed/Collected: None.

Shovel Test Data: None.

Assessment/Recommendations: Less than $50 \%$ of aboriginal rock art appears intact; it lacks associated subsurface deposits. Aboriginal rock art has excellent research potential and is judged to be potentially eligible for listing on NRHP. Recommend detalled recording (see Table 37). 
Location: Ca. $2.2 \mathrm{~km}$ SSW of confluence of Double Mountain Fork and Rocky Creek, and $6.4 \mathrm{~km}$ SW of confluence of Double Mountain Fork and Little Grape Creek.

Description: Open campsite on isolated platform of sandstone bedrock covered by thin layer of eolian sand on erosional remnant terrace overlooking lower alluvial terrace of Rocky Creek; elevation $2240 \mathrm{ft} \mathrm{msl}$, area $3750 \mathrm{~m}^{2}$. Dense scatter including arrow points, chipped stone tools and debitage, burned rock fragments, and two burned rock features. Site has been surface collected; also, heavy equipment probably was driven over site during installment of nearby powerline. Some cobbles of local chert found on terrace below platform, but large amount of debitage, tools, projectile points, and burned rock features are indicative of camping activities. Temporal component is Late Prehistoric.

Features: Two severely deflated and diffuse, ca. 1.5-m-diameter concentrations of burned sandstone.

Cultural Materials Observed/Collected: Deadman's arrow point of local chert, Deadman's arrow point fragment of Edwards chert, two scrapers of Edwards chert, debitage of Edwards chert and local chert, and burned sandstone fragments. Two items collected (see Appendices $\mathrm{A}$ and $\mathrm{B}$ ).

Shovel Test Data: One negative shovel test found soil depth of ca. $23 \mathrm{~cm}$.

Assessment/Recommendations: Less than $25 \%$ of site remains intact; it contains features but may lack subsurface deposits. Site has moderate research potential and is judged to be potentially eligible for listing on NRHP. Recommend controlled collection and mapping.

\section{GR439}

Location: Ca. $2.7 \mathrm{~km}$ SSW of confluence of Double Mountain Fork and Rocky Creek, and $6.8 \mathrm{~km}$ SW of confluence of Double Mountain Fork and Little Grape Creek.

Description: Open campsite on upper canyon rim overlooking Rocky Creek, in area of deep eolian deposits; elevation $2280 \mathrm{ft} \mathrm{msl}$, area $3750 \mathrm{~m}^{2}$. Sparse scatter of debitage with small cluster of possibly burned rocks in erosional areas near canyon rim and in low drainage area farther up from edge. Burned rocks and light lithic scatter indicate camping. No temporal components identified; undefined Prehistoric.

Features: Ca. 1-m-diameter cluster of possibly burned sandstone slabs.

Cultural Materials Observed/Collected: Few flakes of Edwards chert. Two items collected (see Appendices A and B).

Shovel Test Data: Two positive shovel tests yielded debitage to $20-40 \mathrm{~cm}$ and found soils to $40-50 \mathrm{~cm}$. 
Assessment/Recommendations: Over $75 \%$ of site appears intact; it contains features and subsurface deposits. Site has good research potential and is judged to be potentially eligible for listing on NRHP. Recommend controlled collection, mapping, and testing.

\section{GR440}

Location: Ca. $1.8 \mathrm{~km}$ SSW of confluence of Double Mountain Fork and Rocky Creek, and $6.0 \mathrm{~km}$ SW of confluence of Double Mountain Fork and Little Grape Creek.

Description: Open campsite consisting of single burned rock cluster near top of cutbank of large erosional area above Rocky Creek; elevation $2220 \mathrm{ft} \mathrm{msl}$, area $1 \mathrm{~m}^{2}$. No other cultural materials found in vicinity of feature or in dirt troweled from cutbank. Could be remains of single prehistoric campfire or noncultural sandstone fragment accumulation. Rocks are possibly burned so this may be cultural feature. No temporal components identified; undefined Prehistoric.

Features: Cluster of possibly burned sandstone fragments exposed from surface to depth of $55 \mathrm{~cm}$ in cutbank in shape of inverted triangle $60 \mathrm{~cm}$ wide at top. No organic staining or charcoal flecks in fill. Context observed as rocks were removed suggests they probably were redeposited in gully.

Cultural Materials Observed/Collected: None.

Shovel Test Data: None.

Assessment/Recommendations: Less than 25\% of site appears intact; 1t lacks intact subsurface deposits. Site has no research potential and is judged to be not eligible for listing on NRHP. No further work recommended.

\section{GR441}

Location: Ca. $2.7 \mathrm{~km}$ SSW of confluence of Double Mountain Fork and Rocky Creek, and $6.9 \mathrm{~km}$ SW of confluence of Double Mountain Fork and Little Grape Creek.

Description: Open campsite on deflating rise on alluvial floodplain above Rocky Creek; elevation 2220-2230 ft msl, area 55,000 $\mathrm{m}^{2}$. Scatter of chipped stone tools and debitage, burned rocks, at least one burned rock midden, and two burned rock concentrations. Concentrations may be produced by erosion and contain tools and debitage; one is ca. $20 \times 10 \mathrm{~m}$, other is ca. $5 \mathrm{~m}$ in diameter. Disturbed by buried pipeline and dirt road running parallel to it. No evidence of surface collection. Campsite with some plant or faunal processing. No temporal components identified; undefined Prehistoric.

Features: Small burned rock midden ca. $3 \mathrm{~m}$ long, $2 \mathrm{~m}$ wide, and $40 \mathrm{~cm}$ high consisting of dense mound of burned sandstone fragments. Tools and debitage in mound and adjacent area. Fragments of burned sandstone to one side of mound may constitute separate feature. 
Cultural Materials Observed/Collected: Choppers, scrapers, utilized flakes, and debitage of Potter chert, Edwards chert, red coarse-grained quartzite, and local chert, as well as burned fragments of sandstone, Potter chert, and limestone. One mussel shell fragment. Three items collected (see Appendices A and B).

Shovel Test Data: One shovel test beside midden yielded unifacially edge-trimmed flake, mussel shell fragment, and a burned rock fragment between $0-20 \mathrm{~cm}$ and found soils to at least $30 \mathrm{~cm}$.

Assessment/Recommendations: Over 90\% of site appears intact; it contains features and subsurface deposits. Site has unknown research potential but is judged to be potentially eligible for listing on NRHP. Recommend controlled collection, mapping, and testing.

\section{GR442}

Location: Ca. 2.4 km SSW of confluence of Double Mountain Fork and Rocky Creek, and $6.6 \mathrm{~km}$ SW of confluence of Double Mountain Fork and Little Grape Creek.

Description: Open campsite on erosional remnant terrace and lower alluvial terrace overlooking Rocky Creek; elevation 2230-2240 ft msl, area $2400 \mathrm{~m}^{2}$. Lithic scatter with one burned rock feature and several small concentrations of burned rocks. Activities represented are camping and plant processing. Temporal component identified is middle Archaic.

Features: Two 75-100-cm-diameter clusters of burned sandstone, one on upper terrace and one on lower terrace.

Cultural Materials Observed/Collected: Nolan dart point of Edwards chert; biface fragment, mano, cores, and debitage of Potter chert, Edwards chert, and red coarse-grained quartzite; fragments of burned sandstone and Potter chert. One item collected (see Appendices $A$ and $B$ ).

Shovel Test Data: Two negative shovel test excavated, one on each terrace. Lower terrace had soil depth of ca. $50 \mathrm{~cm}$; upper terrace had soil depth of ca. $40 \mathrm{~cm}$.

Assessment/Recommendations: Less than $50 \%$ of site appears intact; it contains features and subsurface deposits. Site has moderate research potential and is judged to be potentially ellgible for listing on NRHP. Recommend controlled collection, mapping, and testing.

\section{GR444}

Location: Ca. 2.1. km SSW of confluence of Double Mountain Fork and Rocky Creek, and $6.5 \mathrm{~km}$ SW of confluence of Double Mountain Fork and Little Grape Creek.

Description: Open campsite on erosional remnant terrace and knoll overlooking confluence of Rocky Creek and small side drainage; elevation 2240-2260 ft msl, area $30,000 \mathrm{~m}^{2}$. Lithic scatter concentrated on south end of site next to small side drainage. Center of 
site has good amount of soil deposition. Site probably was used for camping, at least on intermittent basis. Temporal component identified is Late Prehistoric.

Features: None.

Cultural Materials Observed/Collected: Untyped corner-notched arrow point of chalcedony; beveled knife fragment of Alibates agate; debitage of Edwards chert, local chert, and coarse-grained quartzites; and fragments of burned sandstone. Two items collected (see Appendices A and B).

Shovel Test Data: Two negative shovel tests found soil depths of $80-100 \mathrm{~cm}$.

Assessment/Recommendations: Over $75 \%$ of site appears intact; it may lack subsurface deposits. Site has unknown research potential and is judged to be potentially eligible for listing on NRHP. Recommend controlled collection, mapping, and testing.

\section{$\underline{41 \mathrm{GR} 445}$}

Location: Ca. $1.9 \mathrm{~km}$ SSW of confluence of Double Mountain Fork and Rocky Creek, and $6.2 \mathrm{~km}$ SW of confluence of Double Mountain Fork and Little Grape Creek.

Description: Rock art site at bottom of vertical rock face near base of bluff overlooking Rocky Creek; elevation $2240 \mathrm{ft} \mathrm{msl,} \mathrm{area} 37.5 \mathrm{~m}^{2}$. Numerous historic inscriptions carved into sandstone panel ca. $15 \mathrm{~m}$ long and $2.5 \mathrm{~m}$ high, with single petroglyph that could be aboriginal (see Fig. 32f). No other indications of aboriginal activity on site and no means of determining age of petroglyph. Panel is badly eroded and has been shot several times. Temporal components are undefined Prehistoric and Historic (see Appendix G for description of historic component).

Features: Possible aboriginal petroglyph consists of circle ca. $10 \mathrm{~cm}$ in diameter with diagonal line drawn through 1 t. It also could be historic inscription of letter "O" or an "Ø."

Cultural Materials Observed/Collected: None.

Shovel Test Data: None.

Assessment/Recommendations: Less than 50\% of possible aboriginal rock art appears intact; it lacks subsurface deposits. Possible aboriginal rock art has moderate research potential and is judged to be potentially eligible for listing on NRHP; however, no further work recommended because it may not be aboriginal.

\section{GR446}

Location: Ca. $1.8 \mathrm{~km}$ SSW of confluence of Double Mountain Fork and Rocky Creek, and $6.1 \mathrm{~km} \mathrm{SW}$ of confluence of Double Moutain Fork and Little Grape Creek. 
Description: Lithic procurement area/open campsite on bedrock terrace overlooking Rocky Creek floodplain; elevation 2220-2230 ft $\mathrm{msl}$, area $6050 \mathrm{~m}^{2}$. Gravels visible on deflating terrace. Lithic scatter with one burned rock feature. Sandstone on site is slightly pink, making identification of burned rocks difficult. Site extensively disturbed by erosion and oilfield activity, which shifted sandstone into small clusters. Two broken concentric circles of burned rock fragments are believed to be result of machine operation. Feature and amount of burned rocks suggest this was a campsite where lithic procurement also took place. No temporal components identified; undefined Prehistoric.

Features: One 2-m-diameter cluster of burned sandstone fragments and debitage.

Cultural Materials Observed/Collected: Biface of maroon Ogallala quartzite; cores, tested cobbles, and flakes of local chert and red coarse-grained quartzite; flakes of Potter chert and Edwards chert; fragments of burned sandstone; and mussel shell fragments. One item collected (see Appendices A and B).

Shovel Test Data: One negative shovel test found soil depth of ca. $90 \mathrm{~cm}$.

Assessment/Recommendations: Less than $50 \%$ of site appears intact; it contains features but may lack subsurface deposits. Site has moderate research potential and is judged to be potentially eligible for listing on NRHP. Recommend controlled collection, mapping, and testing.

\section{$41 \mathrm{GR} 450$}

Location: $\mathrm{Ca} .1 .5 \mathrm{~km}$ SSW of confluence of Double Moutain Fork and Rocky Creek, and $6.1 \mathrm{~km}$ SW of confluence of Double Mountain Fork and Little Grape Creek.

Description: Open campsite on two erosional remnant terraces above side drainage flowing into Rocky Creek; elevation 2220-2240 ft msl, area $5000 \mathrm{~m}^{2}$. Scatter of chipped and ground stone tools, debitage, tested cobbles, mussel shell fragments, and burned rocks concentrated on terrace above floodplain of side drainage. Limited disturbance by construction of well pad near edge of site. Tools, mussel shell fragments, and lithic debris suggest camping or plant processing. No temporal components identified; undefined Prehistoric.

Features: None.

Cultural Materials Observed/Collected: Battered mano/hammerstone of red coarsegrained quartzite; few tested cobbles of Potter chert; flakes of Edwards chert, Potter chert, local chert, and red coarse-grained quartzite; mussel shell fragments; and few fragments of burned Potter chert. Three items collected (see Appendices A and B).

Shovel Test Data: One shovel test yielded cultural materials from $0-20 \mathrm{~cm}$ below surface and found solls depth of ca. $35 \mathrm{~cm}$ deep.

Assessment/Recommendations: Over 50\% of site appears intact; it contains subsurface deposits. Site has moderate research potential and is judged to be potentially eligible for listing on NRHP. Recommend controlled collection, mapping, and testing. 
Location: Ca. $1.7 \mathrm{~km}$ SSW of confluence of Double Mountain Fork and Rocky Creek, and $0.6 \mathrm{~km}$ WNW of confluence of Rocky Creek and large side drainage.

Description: Open campsite on slight ridge on lower alluvial terrace over Rocky Creek; elevation 2220-2240 ft msl, area 11,250 $\mathrm{m}^{2}$. Very sparse lithic scatter in deflated area with gravel exposed on surface. Wide dispersal of cultural materials could be due to erosion and deflation. Site may be remains of one or more short-term camping episodes. Some chippable gravels in creek below site. Temporal component identified is late Archaic.

Features: None.

Cultural Materials Observed/Collected: Untyped corner-notched dart point of Potter chert, gouge of Potter chert, and ca. 10 flakes of Edwards and local chert. One item collected (see Appendices A and B).

Shovel Test Data: One negative shovel test found soil depth of at least $80 \mathrm{~cm}$.

Assessment/Recommendations: Less than $25 \%$ of site appears intact; it may lack subsurface deposits. Site has moderate research potential and is judged to be potentially eligible for listing on NRHP. Recommend controlled collection, mapping, and testing.

\section{$\underline{41 G R 453}$}

Location: Ca. $1.3 \mathrm{~km}$ SSW of confluence of Double Mountain Fork and Rocky Creek, and $5.7 \mathrm{~km}$ SW of confluence of Double Mountain Fork and Little Grape Creek.

Description: Lithic scatter on broad alluvial terrace over floodplain within bend in Rocky Creek; elevation 2220-2240 ft msl, area $5000 \mathrm{~m}^{2}$. Quaternary gravels exposed on surface of terrace by deflation and erosion. Sparse scatter of debitage, single tested cobble, and small debitage concentration less than $5 \mathrm{~m}$ in diameter. Possibly camping area with lithic procurement. No temporal components identified; undefined Prehistoric.

Features: None.

Cultural Materials Observed/Collected: Tested cobble and flakes of Edwards chert and red coarse-grained quartzite. No collections made.

Shovel Test Data: One negative shovel test found soil depth of ca. $30 \mathrm{~cm}$.

Assessment/Recommendations: Over $75 \%$ of site appears intact; it lacks subsurface deposits. Site has low research potential and is judged to be not eligible for listing on NRHP. No further work recommended. 
Location: Ca. $0.7 \mathrm{~km}$ SSW of confluence of Double Mountain Fork and Rocky Creek, and $5.3 \mathrm{~km}$ SW of confluence of Double Mountain Fork and Little Grape Creek.

Description: Open campsite on prominent point of small mesa overlooking Rocky Creek; elevation $2260 \mathrm{ft} \mathrm{msl}$, area $314 \mathrm{~m}^{2}$. Top of mesa is deflated; small gravels are exposed on surface. Sparse scatter of single core and burned rock fragments with two burned rock features. If two features are hearths, area was used as campsite. No temporal components identified; undefined Prehistoric.

Features: Two burned rock clusters, one ca. $50 \mathrm{~cm}$ in diameter and other ca. $30 \mathrm{~cm}$ in diameter. Features are deflated, with small amount of soil separating them from gravels on mesa top.

Cultural Materials Observed/Collected: Battered Potter chert core. No collections made.

Shovel Test Data: Shovel probe indicated soils are ca. $5 \mathrm{~cm}$ thick.

Assessment/Recommendations: Over $50 \%$ of site appears intact; it contains features but lacks subsurface deposits. Site has no research potential and is judged to be not eligible for listing on NRHP. No further work recommended.

\section{GR456}

Location: Ca. $0.2 \mathrm{~km}$ WSW of confluence of Double Mountain Fork and Rocky Creek, and $1.3 \mathrm{~km}$ SSW of confluence of Double Mountain Fork and Gobbler Creek.

Description: Open campsite on bedrock terrace overlooking floodplain at confluence of Double Mountain Fork and Rocky Creek; elevation 2180-2220 ft msl, area $2400 \mathrm{~m}^{2}$. Lithic scatter with burned rock features. Upper part of terrace shows fair amount of eolian, colluvial, and alluvial soil deposition with good potentlal for intact buried cultural deposits. Disturbed somewhat by buried pipeline running through center of site in floodplain below terrace. Eroding areas next to pipeline are where most features are found. Site is open campsite containing evidence of plant processing. No temporal components identified; undefined Prehistoric.

Features: Numerous clusters and small dense scatters of burned sandstone. Most are ca. 75-100 cm in diameter and disturbed, but a few appear to be intact hearths.

Cultural Materials Observed/Collected: Manos; scrapers; chopper; gouge; biface fragment; worked and utilized flakes, cores, and chipping debris of Potter chert, Edwards chert, red coarse-grained quartzite. Biface fragment is of Tecovas jasper. Fragments of burned sandstone. Seven items collected (see Appendices A and B).

Shovel Test Data: Two positive shovel tests. One found debitage at $20-40 \mathrm{~cm}$ and soils to $\mathrm{ca} .83 \mathrm{~cm}$; other found debitage at $0-20 \mathrm{~cm}$ and soils at least $74 \mathrm{~cm}$ deep. 
Assessment/Recommendations: Over $75 \%$ of site appears intact; it contains subsurface deposits, features, and exotics. Site has excellent research potential and is judged to be potentially eligible for listing on NRHP. Recommend controlled collection, mapping, and testing.

\section{$\underline{41 G R 457}$}

Location: Ca. $0.8 \mathrm{~km}$ SSW of confluence of Double Mountain Fork and Rocky Creek, and $5.5 \mathrm{~km}$ SW of confluence of Double Mountain Fork and Little Grape Creek.

Description: Rock art site in bluff overhang on steep valley slope below large knoll overlooking Rocky Creek; elevation $2230 \mathrm{ft} \mathrm{msl}$, area $4500 \mathrm{~m}^{2}$. Shelter formed by erosion of softer stratum of light brown sandstone below harder stratum of dark brown sandstone. Several panels of aboriginal rock art (see Fig. $32 \mathrm{~g}$ ) on sandstone floor below overhang. No soil on floor of shelter area. Damaged by erosion and spalling of sandstone. No temporal components identified; undefined Prehistoric.

Features: Five petroglyph panels on floor of shelter in area ca. $150 \mathrm{~cm}$ long and 30 $\mathrm{cm}$ tall. From left to right, first panel is $28 \mathrm{~cm}$ tall and $16 \mathrm{~cm}$ wide. Has two pairs of parallel diagonal lines, one pair ca. $16 \mathrm{~cm}$ above other; both curve upward to left. Lower pair of lines is ca. $20 \mathrm{~cm}$ long and $2 \mathrm{~cm}$ apart; upper pair is $15 \mathrm{~cm}$ long and $2 \mathrm{~cm}$ apart. Lines are faint and could be claw marks of animal. Second panel is $4 \mathrm{~cm}$ to right of first; it is $36 \mathrm{~cm}$ long and $11 \mathrm{~cm}$ tall and consists of complex pattern of lines. Vague rhomboidal shape is defined by intersecting parallel and diagonal lines at each end of figure, with two vertical parallel lines and single curving vertical line drawn from top of figure to point below bottom. Third panel is $25 \mathrm{~cm}$ to left of second and is single inverted "V" $7 \mathrm{~cm}$ wide and $8 \mathrm{~cm}$ tall. Fourth panel is $4 \mathrm{~cm}$ farther to left and is $11 \mathrm{~cm}$ wide and $6 \mathrm{~cm}$ tall; two rectangular figures ca. $6 \mathrm{~cm}$ apart, with sideways "V" and short horizontal line below them. Fifth panel is $29 \mathrm{~cm}$ farther to left; it contains group of intersecting straight horizontal and diagonal lines which do not form any distinct figure.

Cultural Materials Observed/Collected: None.

Shovel Test Data: None.

Assessment/Recommendations: Less than $25 \%$ of site appears intact; it contains features but lacks subsurface deposits. Site has excellent research potential and is judged to be potentially eligible for listing on NRHP. Recommend detailed recording (see Table 37).

\section{GR458}

Location: Ca. $0.4 \mathrm{~km}$ SSW of confluence of Double Mountain Fork and Rocky Creek, and $5.2 \mathrm{~km}$ SW of confluence of Double Mountain Fork and Little Grape Creek.

Description: Open campsite on and around small erosional remnant mesa overlooking Rocky Creek floodplain; elevation 2240-2270 ft msl, area 50,000 $\mathrm{m}^{2}$. Top of mesa almost 
totally devoid of soil, while surrounding areas have thin deposit of eolian sand. Sparse scatter of chipped and ground stone tools and debitage. Burned rock fragments concentrated In two 2-m-diameter areas may have been features dispersed through erosion and deflation. Small campsite with evidence of plant processing. No temporal components identified; undefined Prehistoric.

Features: None.

Cultural Materlals Observed/Collected: Five manos (sandstone and quartzite); Edwards chert biface; quartzite scraper; a Potter chert core; debitage of Edwards chert, Potter chert, and coarse-grained quartzite; burned sandstone fragments; and few fragments of burned limestone. One item collected (see Appendices A and B).

Shovel Test Data:' Two negative shovel tests found soil depths of 30 and $60 \mathrm{~cm}$.

Assessment/Recommendations: Over 50\% of site appears intact; it may lack subsurface deposits. Site has moderate research potential and is judged to be potentially eligible for listing on NRHP. Recommend controlled collection and mapping.

\section{$41 \mathrm{GR} 459$}

Location: Ca. $1.5 \mathrm{~km} \mathrm{NE}$ of U.S. Highway 84 bridge over Sand Creek, and $0.8 \mathrm{~km}$ SSW of confluence of Double Mountain Fork and Sand Creek.

Description: Open campsite on upland terrace above Sand Creek; elevation $2220 \mathrm{ft} \mathrm{msl}$, area $2000 \mathrm{~m}^{2}$. Scatter of debitage and burned quartzite fragments, with utilized flake. Burned rock concentration ca. $15 \mathrm{~m}$ in diameter located next to exposed sandstone edge of terrace could be remains of one large burned rock feature or several small ones. Somewhat disturbed by pasture road which runs through site near burned rock concentration and by stock tank bullt below terrace on other side of concentration. May have been surface collected. Activities represented are camping and chipped stone tool manufacture. No temporal components identified; undefined Prehistoric.

Features: None.

Cultural Materials Observed/Collected: Utilized Edwards chert flake, Edwards chert flakes, and burned fragments of Potter chert and coarse-grained quartzite. No collections made.

Shovel Test Data: One negative shovel test found soil depth of ca. $25 \mathrm{~cm}$.

Assessment/Recommendations: Less than $50 \%$ of s1te appears intact; it lacks subsurface deposits. Site has moderate research potential and is judged to be potentially eligible for listing on NRHP. Recommend controlled collection and mapping.

\section{GR462}

Location: Ca. $2.2 \mathrm{~km}$ ENE of U.S. Highway 84 bridge over Sand Creek, and $4.5 \mathrm{~km}$ ESE of U.S. Highway 84 bridge over Double Mountain Fork. 
Description: Open campsite on deflated upland point overlooking confluence of Double Mountain Fork and Sand Creek; elevation $2260 \mathrm{ft} \mathrm{msl}$, area $314 \mathrm{~m}^{2}$. Two burned rock clusters and scatter of burned rock fragments. Small campsite occupied for short period of time. No temporal components identified; undefined Prehistoric.

Features: Two burned rock clusters; both ca. $1 \mathrm{~m}$ in diameter. One is composed of ca. 10 fragments of burned sandstone and Potter chert; other contains only ca. 10-15 burned sandstone fragments.

Cultural Materials Observed/Collected: Fragments of burned sandstone and Potter chert. No collections made.

Shovel Test Data: One negative shovel test found ca. $10 \mathrm{~cm}$ of soil.

Assessment/Recommendations: Less than $50 \%$ of site appears intact; it lacks subsurface deposits. Site has no research potential and is judged to be not eligible for listing on NRHP. No further work recommended.

\section{GR466}

Location: Ca. $0.9 \mathrm{~km}$ WNW of confluence of Double Mountain Fork and Sand Creek, and $4.9 \mathrm{~km}$ SE of intersection of U.S. Highway 84 and FM 2458.

Description: Lithic procurement area on upland canyon rim above Double Mountain Fork in Quaternary gravel outcrop; elevation $2260 \mathrm{ft} \mathrm{msl}$, area $12,800 \mathrm{~m}^{2}$. Sparse lithic scatter. Lithic procurement with evidence of other activities; most gravels small, so not used intensively. No temporal components identified; undefined Prehistoric.

Features: None.

Cultural Materials Observed/Collected: Core of red coarse-grained quartzite, crude scraper or chopper of Potter chert, tested Potter chert cobble, few flakes of Potter chert, and fire-cracked Potter chert nodule. No collections made.

Shovel Test Data: None.

Assessment/Recommendations: Over $75 \%$ of site appears intact; it lacks subsurface deposits. Site has low research potential and is judged to be not eligible for listing on NRHP. No further work recommended.

\section{$\underline{41 \mathrm{GR} 467}$}

Location: Ca. $4.3 \mathrm{~km}$ ESE of intersection of U.S. Highway 84 and FM 2458, and $1.5 \mathrm{~km}$ NNW of confluence of Double Mountain Fork and Sand Creek.

Description: Open campsite on two dunes on edge of Double Mountain Fork floodplain; elevation $2230 \mathrm{ft} \mathrm{msl}$, area $3325 \mathrm{~m}^{2}$. Dunes separated by small, shallow drainage, and old 
dirt road runs across them. Sparse lithic scatter on surface; majority of cultural deposits buried in stratified context. Probable campsite. No temporal components identified; undefined Prehistoric.

Features: See Shovel Test Data.

Cultural Materials Observed/Collected: Edwards chert flakes, Potter chert flake, Potter chert core, and burned sandstone fragments. Three items collected (see Appendices A and B).

Shovel Test Data: Three shovel tests excavated, all positive with soll depth of at least $120 \mathrm{~cm}$. One test yielded cultural materials at 0-20 cm, and another contained burned sandstone (not collected) at 20-40 cm below surface. Third test encountered layer of possibly burned rocks (possible feature) at 40-60 cm and cultural materials between 60-80 and $100-120 \mathrm{~cm}$.

Assessment/Recommendations: Over $90 \%$ of site appears intact; it contains subsurface deposits and may have features. Site has good research potential and is judged to be potentially eligible for listing on NRHP. Recommend mapping and testing.

\section{GR471}

Location: Ca. $3.7 \mathrm{~km}$ ESE of intersection of U.S. Highway 84 and FM 2458, and $3.1 \mathrm{~km}$ NNW of U.S. Highway 84 bridge over Sand Creek.

Description: Open campsite on dune on bluff slope and on small erosional remnant terrace overlooking Double Mountain Fork; elevation 2220-2245 ft msl, area $10,075 \mathrm{~m}^{2}$. Small drainage dissects dune. Scatter of debitage, core, and burned rock fragments eroding into drainages in dune and surface of remnant terrace. Burned rocks suggest camping. No temporal components identified; undefined Prehistoric.

Features: None.

Cultural Materials Observed/Collected: Flakes of local chert, Potter chert, and Edwards chert; red coarse-grained quartzite core; burned sandstone fragments; and burned quartzite fragment. One item collected (see Appendices A and B).

Shovel Test Data: Five negative shovel tests found soil depths of at least $120 \mathrm{~cm}$.

Assessment/Recommendations: Over $90 \%$ of site appears intact; it may lack subsurface deposits. Site has unknown research potential and is judged to be potentially eligible for listing on NRHP. Recommend mapping and testing.

\section{GR472}

Location: Ca. $2.4 \mathrm{~km}$ SE of confluence of Double Mountain Fork and Salt Branch, and $3.0 \mathrm{~km}$ NNW of U.S. Highway 84 bridge over Sand Creek. 
Description: Rock art site in bluff overhang shelter on gentle slopes overlooking Double Mountain Fork; elevation $2280 \mathrm{ft} \mathrm{msl}$, area less than $1 \mathrm{~m}^{2}$. Shelter formed by erosion of soft light gray sandstone from below stratum of harder conglomerate sandstone. Petroglyph panel (see Fig. 33a) on back wall of shelter; floor of shelter bare except for small fragments of roof spall. No temporal components identified; undefined Prehistoric.

Features: Panel of petroglyphs $200 \mathrm{~cm}$ long and $20 \mathrm{~cm}$ tall along edge of shelf. Series of ca. 67 vertical tally marks with two long parallel horizontal lines running through center. Other marks along shelf are faint and may not be cultural.

Cultural Materials Observed/Collected: None.

Shovel Test Data: None.

Assessment/Recommendations: Over $75 \%$ of site appears intact; it preserves features but lacks subsurface deposits. Site has excellent research potential and is judged to be potentially eligible for listing on NRHP. Recommend detailed recording (see Table 37 ).

\section{GR474}

Location: Ca. $2.5 \mathrm{~km} \mathrm{SE}$ of intersection of U.S. Highway 84 and FM 2458 , and $1.5 \mathrm{~km}$ ESE of U.S. Highway 84 bridge over Double Mountain Fork.

Description: Open campsite on an eroded upland remnant in bend in Double Mountain Fork; elevation 2220-2260 ft $\mathrm{msl}$, area 120,000 $\mathrm{m}^{2}$. Sand dunes on areas adjacent to river; erosional gullies expose bedrock in high areas. Extensive scatter of ground and chipped stone tools, debitage, burned rocks, and burned rock features. Major historic component in western and northwestern parts of site. Historic occupants and others probably collected artifacts from surface. Disturbed by dirt road through center of site. Prehistoric occupation represents repeated camping episodes, with plant processing. Temporal components Identified are Late Prehistoric and Historic (see Appendix G for description of historic component).

Features: Two features; one burned sandstone cluster measuring $50 \mathrm{~cm}$ in diameter, and one small (ca. $200 \mathrm{~cm}$ in diameter), dense scatter of burned Potter chert fragments. Sandstone cluster is hearth, while burned Potter chert scatter could be boiling stone dump.

Cultural Materials Observed/Collected: Unidentified arrow point fragment, sandstone mano, choppers, scrapers, and debitage. Raw materials are Potter chert, Edwards chert, and local chert, with some coarse-grained quartzite. Fragments of burned sandstone and Potter chert. Three items collected (see Appendices A and B).

Shovel Test Data: Three shovel tests excavated; two positive. Negative test indicated soil depth of ca. $55 \mathrm{~cm}$. Positive tests yielded cultural materials at 40-60 and 60-80 $\mathrm{cm}$ and indicated soil depth of at least $80 \mathrm{~cm}$.

Assessment/Recommendations: Over $90 \%$ of prehistoric component appears intact; it includes features and subsurface deposits. Prehistoric component has good research potential and is judged to be potentially eligible for listing on NRHP. Recommend controlled collection, mapping, and testing. 


\section{$41 \mathrm{GR} 476$}

Location: Ca. $3.5 \mathrm{~km}$ NW of confluence of Double Mountain Fork and Sand Creek, and 1.2 $\mathrm{km}$ SSE of confluence of Double Mountain Fork and Salt Branch.

Description: Open campsite on two slight rises and erosional area between them on lower alluvial terrace of Double Mountain Fork; elevation $2245 \mathrm{ft} \mathrm{msl}$, area $8000 \mathrm{~m}^{2}$. Sparse scatter of debitage and burned rock fragments. These materials and lack of evidence of earlier stages of lithic reduction suggest small, short-term campsite. No temporal components Identified; undefined Prehistoric.

Features: None.

Cultural Materlals Observed/Collected: Flakes of Edwards chert and local chert, fragments of burned Potter chert. One item collected (see Appendices A and B).

Shovel Test Data: One shovel test yielded a flake between $40-60 \mathrm{~cm}$ and found soils at least $80 \mathrm{~cm}$ deep.

Assessment/Recommendations: Over $75 \%$ of site appears intact; it contains subsurface deposits. Site has no research potential and is judged to be not eligible for listing on NRHP. No further work recommended.

\section{GR477}

Location: Ca. $3.6 \mathrm{~km}$ NW of confluence of Double Mountain Fork and Sand Creek, and 1.1 $\mathrm{km}$ SSE of confluence of Double Mountain Fork and Salt Branch.

Description: Open campsite on and around low ridge within lower alluvial terrace of Double Mountain Fork; elevation 2230-2240 ft msl, area 28,000 $\mathrm{m}^{2}$. Ridge adjoins small drainage which runs through terrace. Sparse scatter of debitage and burned rock fragments. Small campsite used Intermittently or for short period of time. No temporal components identified; undefined Prehistoric.

Features: None.

Cultural Materials Observed/Collected: Flakes of Edwards chert, Potter chert, and local chert; fragments of burned Potter chert and sandstone. One item collected (see Appendices $\mathrm{A}$ and $\mathrm{B}$ ).

Shovel Test Data: Two shovel tests excavated, one positive. Negative test off ridge found soil depth of ca. $48 \mathrm{~cm}$. Positive test on ridge yielded flake at $10 \mathrm{~cm}$ and found soils to ca. $60 \mathrm{~cm}$.

Assessment/Recommendations: Over $75 \%$ of site appears intact; it contains subsurface deposits. Site has no research potential and is judged to be not eligible for listing on NRHP. No further work recommended. 


\section{GR478}

Location: Ca. $2.1 \mathrm{~km} \mathrm{SE}$ of intersection of U.S. Highway 84 and FM 2458, and $3.7 \mathrm{~km} \mathrm{NW}$ of confluence of Double Mountain Fork and Sand Creek.

Description: Open campsite at streamward edge of lower alluvial terrace above Double Mountain Fork; elevation $2240 \mathrm{ft} \mathrm{msl,} \mathrm{area} 4000 \mathrm{~m}^{2}$. Half of site in plowed fleld; drainage at south end of site flows into river. Small sparse scatter of cores, debitage, sandstone manuports, and fragments of burned rocks, with burned rock feature in uncultivated area. Burned rocks scattered across fleld probably are from features which have been destroyed by plowing. Small campsite. No temporal components identified; undefined Prehistoric.

Features: Cluster ca. $80 \mathrm{~cm}$ in diameter of burned sandstone slabs eroding from edge of terrace above drainage probably is hearth.

Cultural Materials Observed/Collected: Two cores and flakes of Potter chert, sandstone manuports, and fragments of burned sandstone and Potter chert. No collections made.

Shovel Test Data: Two negative shovel tests found soil depths of at least $80-100 \mathrm{~cm}$.

Assessment/Recommendations: Over 50\% of site appears intact; it contains features and may have subsurface deposits. Site has unknown research potential and is judged to be potentially eligible for listing on NRHP. Recommend mapping and testing.

\section{GR479}

Location: Ca. $1.4 \mathrm{~km}$ SE of intersection of U.S. Highway 84 and FM 2458, and $0.8 \mathrm{~km}$ SSW of confluence of Double Mountain Fork and Salt Branch.

Description: Open campsite on edge of lower alluvial terrace above Double Mountain Fork; elevation $2240 \mathrm{ft} \mathrm{msl}$, area $30,000 \mathrm{~m}^{2}$. Terrace dissected by several small drainages has lithic scatter on surface. Extensively disturbed by borrow pit, trash dump, dirt road, and cultivation. Open campsite lacking features because of extensive disturbance. No temporal components identified; undefined Prehistoric.

Features: None.

Cultural Materials Observed/Collected: Sandstone mano fragment, flakes of Edwards chert and local chert, and fragments of burned Potter chert. No collections made.

Shovel Test Data: Two negative shovel tests found soil depth of at least $100 \mathrm{~cm}$.

Assessment/Recommendations: Less than $25 \%$ of site remains intact; it lacks subsurface deposits. Site has no research potential and is judged to be not eligible for listing on NRHP. No further work recommended. 


\section{$\underline{41 G R 480}$}

Location: Ca. $0.3 \mathrm{~km}$ NW of intersection of Garza/Kent county Iine and Double Mountain Fork, and $3.2 \mathrm{~km} \mathrm{NE}$ of confluence of Double Mountain Fork and Little Grape Creek.

Description: Lithic procurement area on upland canyon rim overlooking Double Mountain Fork; elevation $2280 \mathrm{ft} \mathrm{msl}$, area $12,500 \mathrm{~m}^{2}$. Quaternary gravel outcrop with large amount of Potter chert on surface. Sparse scatter of tested cobbles and debitage corresponding with Potter chert outcrop. Lithic procurement area not used intensively or often. No temporal components identified; undefined Prehistoric.

Features: None.

Cultural Materials Observed/Collected: Flakes and tested cobbles of Potter chert. No collections made.

Shovel Test Data: None.

Assessment/Recommendations: Over $75 \%$ of site appears intact; it lacks subsurface deposits. Site has good research potential and is judged to be potentially eligible for listing on NRHP. Recommend controlled collection and mapping.

\section{$41 \mathrm{GR} 481$}

Location: Ca. $1.5 \mathrm{~km}$ WNW of intersection of Garza/Kent county line and Double Mountain Fork, and $2.6 \mathrm{~km} \mathrm{NNE}$ of confluence of Double Mountain Fork and Little Grape Creek.

Description: Open campsite on small upland rise about $1 \mathrm{~km}$ north of canyon $\mathrm{rim}$ of Double Mountain Fork; elevation $2320 \mathrm{ft} \mathrm{msl}$, area $60,000 \mathrm{~m}^{2}$. Sparse 1ithic scatter disturbed by brush clearing and two dirt roads which run through center of site. Small, short-term campsite; heat-fractured debitage and burned rock are evidence of fires. No temporal components 1dentified; undefined Prehistoric.

Features: None.

Cultural Materials Observed/Collected: Potter chert chopper, tertiary flakes of Edwards and Potter chert, and burned fragment of Potter chert. No collections made.

Shovel Test Data: None.

Assessment/Recommendations: Over $50 \%$ of site appears intact; it lacks subsurface deposits. Site has no research potential and is judged to be not eligible for listing on NRHP. No further work recommended.

\section{GR483}

Location: Ca. $0.8 \mathrm{~km}$ SW of confluence of Double Mountain Fork and Grape Creek, and $4.9 \mathrm{~km}$ ENE of confluence of Double Mountain Fork and Cat Hollow. 
Description: Open campsite at base of bluff on upper alluvial terrace above Grape Creek; elevation 2160 ft msl, area unknown. Group of burned sandstone slabs found in one end of one of three backhoe trenches excavated in terrace. Below slabs is line of sandstone cobbles. No artifacts found in association with feature or on surface. Camping area or midden, but size of site not known. No temporal components identified; undefined Prehistoric.

Features: Group of burned sandstone slabs from $75-95 \mathrm{~cm}$ and line of sandstone cobbles from 200-220 cm below surface in backhoe trench. Soil around line of cobbles has flecks of charcoal and appears to be slightly burned.

Cultural Materials Observed/Collected: Burned sandstone slabs, cobbles, and charcoal in Backhoe Trench 1 . No collections made.

Shovel Test Data: None.

Assessment/Recommendations: Over $90 \%$ of site appears intact; it contains features and subsurface deposits. Site has unknown research potential and is judged to be potentially eligible for listing on NRHP. Recommend mapping and testing.

$\underline{41 G R 484}$

Location: Ca. $0.1 \mathrm{~km}$ ESE of confluence of Double Mountain Fork and Grape Creek, and $2.2 \mathrm{~km}$ SSW of confluence of Double Mountain Fork and South Sage Creek.

Description: Open campsite in lower alluvial terrace at confluence of Grape Creek and Double Mountain Fork; elevation 2130-2150 ft msl, area $2100 \mathrm{~m}^{2}$. Cultural materials found in cutbank, in backhoe trench, and on surface; one burned rock feature noted. Majority of cultural materials found below surface. Chain clearing and root plowing may have disturbed site to depth of ca. $65 \mathrm{~cm}$. Camping area with plant processing. No temporal components identified; undefined Prehistoric.

Features: Burned sandstone slabs and mano in cluster ca. $100 \mathrm{~cm}$ in diameter and $25 \mathrm{~cm}$ below surface. Abundant charcoal in feature was sampled for radiocarbon assay. Bison bones found in backhoe trench at depth of $40 \mathrm{~cm}$. Possible burled cultural horizon marked by charcoal flecks in Double Mountain Fork cutbank at depth of about $1 \mathrm{~m}$.

Cultural Materials Observed/Collected: Mano fragment, bison bones, burned sandstone slabs, and charcoal. Samples of bones, soil, and charcoal collected (see Appendices A and B).

Shovel Test Data: None.

Radiocarbon Dates: Radiocarbon assays were obtained on three samples from site. Sample of charcoal from hearth in cutbank dated to $260 \pm 70$ B.P. (Tx-5758). Soil sample associated with bison bones in Backhoe Trench 14 dated to $1160 \pm 60$ B.P. (Tx-5765). Another soil sample from depth of $1.5 \mathrm{~m}$ in same backhoe trench dated to $1830 \pm 70$ B.P. $(T x-5766)$. These dates are in correct stratigraphic order, but possible cultural materials are only associated with youngest date. 
Assessment/Recommendations: Over $50 \%$ of site appears intact; it contains features and subsurface deposits. Site has good research potential and is judged to be potentially eligible for listing on NRHP. Recommend mapping and testing.

\section{GR485}

Location: Ca. $0.8 \mathrm{~km}$ ESE of confluence of Double Mountain Fork and Cat Hollow, and $2.6 \mathrm{~km} \mathrm{NE}$ of confluence of Double Mountain Fork and Rocky Creek.

Description: Open campsite in narrow dune on alluvial terrace above the Double Mountain Fork; elevation $2170 \mathrm{ft} \mathrm{msl}$, area $300 \mathrm{~m}^{2}$. Dune eroded at one end by small drainage cutting through alluvial terrace. Small scatter of burned sandstone slabs found in backhoe trench; no other cultural materials. Campsite which probably was used on intermittent basis. No temporal components identifled; undefined Prehistoric.

Features: Cluster of sandstone slabs in wall of backhoe trench at depth of ca. 150$170 \mathrm{~cm}$; few flecks of charcoal in soil around feature.

Cultural Materials Observed/Collected: Burned sandstone slabs, charcoal. No collections made.

Shovel Test Data: One negative shovel test; backhoe trench indicated soil depth of ca. $2.6 \mathrm{~m}$.

Assessment/Recommendations: Over 50\% of site appears intact; it contains features and subsurface deposits. Site has unknown research potential and is judged to be potentially eligible for listing on NRHP. Recommend mapping and testing.

\section{GR487}

Location: Ca. 2.0 km NE of confluence of Double Mountain Fork and Red Branch, and 6.4 $\mathrm{km} \mathrm{E}$ of U.S. Highway 84 bridge over Double Mountain Fork.

Description: Open campsite on erosional remnant bench on valley slopes overlooking

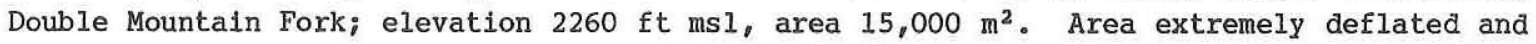
eroded, with small mounds of remaining soll. Sparse 1ithic scatter with 20x15-m diffuse scatter of burned rocks which may have been feature prior to disturbance by erosion. Campsite with no evidence of lithic procurement. No temporal components identified; undefined Prehistoric.

Features: None.

Cultural Materials Observed/Collected: Three Potter chert choppers; possible cores; flakes (mostly primary and secondary) of Potter, Edwards, and local chert; and fragments of burned Potter chert. No collections made.

Shovel Test Data: One negative shovel test excavated in area with remnant soils found soll depth of at least $100 \mathrm{~cm}$. 
Assessment/Recommendations: Over $75 \%$ of site appears intact; it lacks subsurface deposits. Site has no research potential and is judged to be not eligible for listing on NRHP. No further work recommended.

\section{$41 \mathrm{GR} 488$}

Location: Ca. $6.4 \mathrm{~km}$ E of U.S. Highway 84 bridge over Double Mountain Fork, and 1.7 $\mathrm{km} \mathrm{NE}$ of confluence of Double Mountain Fork and Red Branch.

Description: Faunal locality in cutbank of erosional drainage running through upper alluvial terrace of Double Mountain Fork; elevation $2240 \mathrm{ft} \mathrm{msl,} \mathrm{area} 50 \mathrm{~m}^{2}$. Two areas of bison bone fragments, one area in cutbank and one area in floor of drainage ca. $30 \mathrm{~m}$ downstream. Bone in cutbank was ca. $120 \mathrm{~cm}$ below surface, with charcoal fleck ca. $60 \mathrm{~cm}$ above it. Bone fragments downstream were in bottom of gully on gravel bed. Nearby profile of cutbank revealed possible burned rock ca. $80 \mathrm{~cm}$ below surface. No conclusive evidence of cultural activity in association with bone fragments. No temporal components identifled; undefined Prehistoric.

Features: None.

Cultural Materials Observed/Collected: Three fragments of small bison (could be cow) bone, possible burned rocks, and charcoal. One charcoal sample collected (see Appendices A and $\mathrm{B})$.

Shovel Test Data: Two shovel tests excavated, one positive. Negative test found soil depth of at least $130 \mathrm{~cm}$. Positive test encountered charcoal fragments to ca. $80 \mathrm{~cm}$ and soils to at least $100 \mathrm{~cm}$.

Assessment/Recommendations: Less than $50 \%$ of site appears intact; it contains subsurface deposits. Site has good research potential and is judged to be potentially eligible for listing on NRHP. Recommend mapping and testing.

\section{$\underline{41 G R 489}$}

Location: Ca. $1.9 \mathrm{~km} \mathrm{NE}$ of confluence of Double Mountain Fork and Rocky Creek, and $0.4 \mathrm{~km}$ SSE of confluence of Double Mountain Fork and Cat Hollow.

Description: Lithic procurement area in erosional drainage area on upland margin and downslope above Double Mountain Fork; elevation 2220-2260 ft msl, area 19,800 $\mathrm{m}^{2}$. Large lithic scatter concentrated on small ridge on west edge of site. Lithic procurement area which was not utilized very extensively. No temporal components identified; undefined Prehistoric.

Features: None.

Cultural Materials Observed/Collected: Scraper, cores, tested cobbles, and flakes of Potter chert, coarse-grained quartzite, and local chert; flakes of Edwards chert. One item collected (see Appendices A and B). 
Shovel Test Data: Two negative shovel tests found soil depths of 30 and $50 \mathrm{~cm}$.

Assessment/Recommendations: Over 90\% of site appears intact; it lacks subsurface deposits. Site has low research potential and is judged to be not eligible for listing on NRHP. No further work recommended.

\section{1 GR490}

Location: Ca. $1.8 \mathrm{~km}$ NNE of confluence of Double Mountain Fork and Rocky Creek, and $0.4 \mathrm{~km}$ SSW of confluence of Double Mountain Fork and Cat Hollow.

Description: Rock art site at base of vertical sandstone bluff at bottom of steep valley slope above Double Mountain Fork; elevation $2210 \mathrm{ft} \mathrm{msl}$, area $4 \mathrm{~m}^{2}$. Two aboriginal petroglyph panels (see Fig. $33 \mathrm{~b}-\mathrm{c}$ ) in area ca. $4 \mathrm{~m}$ long and $1 \mathrm{~m}$ tall. Thin deposit of soil at bottom of sandstone face, but no cultural materials present. No temporal components identified; undefined Prehistoric.

Features: Two panels of aboriginal petroglyphs ca. $4 \mathrm{~m}$ apart. One panel ca. $25 \mathrm{~cm}$ wide and ca. $23 \mathrm{~cm}$ tall contains two elements; one $1 \mathrm{~s}$ single vertical line $5 \mathrm{~cm}$ long, other is vertical line intersected by diagonal line. Each line has short "barb" drawn outward from upper end. Second element is $18 \mathrm{~cm}$ tall and $15 \mathrm{~cm}$ wide. Second panel is single element formed by vertical line $10 \mathrm{~cm}$ long bisected by horizontal 1 ine $10 \mathrm{~cm}$ long.

Cultural Materlals Observed/Collected: None.

Shovel Test Data: Shovel probe indicated that soll depth at base of bluff face is ca. $27 \mathrm{~cm}$.

Assessment/Recommendations: Over $90 \%$ of site appears intact; it preserves features but lacks subsurface deposits. Site has excellent research potential and is judged to be potentially eligible for listing on NRHP. Recommend detailed recording (see Table 37 ).

\section{$41 \mathrm{GR} 491$}

Location: Ca. $1.3 \mathrm{~km} \mathrm{NNE}$ of confluence of Double Mountain Fork and Rocky Creek, and $4.0 \mathrm{~km}$ WSW of confluence of Double Mountain Fork and Little Grape Creek.

Description: Rock art site in rockshelter eroded out of small point below upland

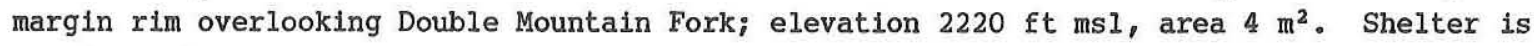
ca. $2 \mathrm{~m}$ wide and $2 \mathrm{~m}$ deep, with floor of exposed bedrock. Several panels of aboriginal rock art (see Fig. 33d-e) and recent graffiti on floor of shelter, with one on rock face above mouth of shelter. One panel damaged somewhat by recent graffiti. No temporal components identified; undefined Prehistoric.

Features: Three panels of aboriginal petroglyphs. First is ca. $10 \mathrm{~cm}$ wide and $8 \mathrm{~cm}$ tall; two perpendicular intersecting lines with three lines ca. $5 \mathrm{~cm}$ long radiating out of center in upper half of figure (two lines on one side and one on other). Second panel is 
ca. $40 \mathrm{~cm}$ tall and $30 \mathrm{~cm}$ wide, with three parallel diagonal lines, one $18 \mathrm{~cm}$ long and other two $7 \mathrm{~cm}$ long, and element resembling asterisk consisting of four 1ines ca. 15-17 cm long intersecting at centers. Other lines form rough, angular circle around center of "asterisk" so that it resembles spider web. Third panel on rock face above mouth of shelter measures $50 \mathrm{~cm}$ long and $17 \mathrm{~cm}$ tall and has two elements. One is long shallow arc ca. $20 \mathrm{~cm}$ long and $7 \mathrm{~cm}$ deep, with diagonal lines drawn out from both ends of arc on convex side; total dimension of element is $27 \mathrm{~cm}$ wide and $7 \mathrm{~cm}$ tall. Other element is 10-cm-tall, 1-cmwide, and 10-cm-long vertical line with 5-cm-long diagonal line drawn upward from its bottom.

Cultural Materials Observed/Collected: None.

Shovel Test Data: One negative shovel test in soil deposits outside shelter found soil depth of ca. $70 \mathrm{~cm}$.

Assessment/Recommendations: Over $90 \%$ of site appears intact; it preserves features but lacks subsurface deposits. Site has excellent research potential and is judged to be potentially eligible for listing on NRHP. Recommend detailed recording (see Table 37 ).

\section{$\underline{41 \mathrm{GR} 493}$}

Location: Ca. $2.5 \mathrm{~km} \mathrm{NE}$ of confluence of Double Mountain Fork and Sand Creek, and 1.8 $\mathrm{km}$ NNE of confluence of Double Mountain Fork and Red Branch.

Description: Open campsite on edge of upland margin above confluence of small unnamed drainage and Double Mountain Fork; elevation 2260-2280 ft msl, area $2250 \mathrm{~m}^{2}$. Scatter of ground and chipped stone tools, debitage, and burned rocks, with several small concentrations of burned rocks in areas of less disturbance. Severely disturbed by well pad and tank battery and by brush clearing and leveling. Surface collection evident. Small camping area with plant processing and some lithic procurement or reduction. No temporal components identified; undefined Prehistoric.

Features: Three small concentrations of burned sandstone and limestone ca. $7 \mathrm{~m}$ in diameter are probably eroded and deflated hearths.

Cultural Materials Observed/Collected: Two bifaces, two manos, cores, and debitage of Potter and Edwards chert and coarse-grained quartzite; fragments of burned sandstone, Potter chert, and limestone. Six items collected (see Appendices A and B).

Shovel Test Data: One shovel test yielded debitage at 0-20 cm and found soils $25 \mathrm{~cm}$ deep.

Assessment/Recommendations: Less than $50 \%$ of site appears intact; it contains features and subsurface deposits. Site has good research potential and is judged to be potentially eligible for listing on NRHP. Recommend mapping and testing. 
Location: Ca. $7.0 \mathrm{~km}$ SSE of intersection of U.S. Highway 84 and FM 2458, and $2.5 \mathrm{~km}$ NE of confluence of Double Mountain Fork and Sand Creek.

Description: Rock art site in bluff overhang shelter just below upland margin rim at head of small drainage above Double Mountain Fork; elevation $2260 \mathrm{ft} \mathrm{msl}$, area $60 \mathrm{~m}^{2}$. Area in front of ca. 20-m-long and 4-m-deep shelter covered with large fragments of sandstone fallen from roof. Floor has thin deposit of sterile sand from weathering of bedrock. Seven panels of rock art, two aboriginal (see Fig. 33f). Aboriginal art undisturbed by later historic inscriptions. Temporal components are undefined Prehistoric and Historic (see Appendix G for description of historic component).

Features: Two large panels of aboriginal petroglyphs; one ca. $210 \mathrm{~cm}$ long and $30 \mathrm{~cm}$ tall has long series of tally marks which often overlap, with small geometric shapes and chevron figure drawn over them. Below main group of tally marks is smaller set $40 \mathrm{~cm} 1 \mathrm{ong}$ and $\mathrm{ca} .7 \mathrm{~cm}$ tall of 14 vertical marks with horizontal line drawn through them. To right of tally marks is another set of five smaller marks $25 \mathrm{~cm}$ long and 5-10 cm tall. Second panel (180 cm long and $50 \mathrm{~cm}$ tall) includes numerous tally marks and geometric figures. Among these are ca. 30 vertical and diagonal tally marks, some of which overlap or intersect, chevron figure ca. $20 \mathrm{~cm}$ wide and $35 \mathrm{~cm}$ tall with asterisk at upper end, and retangular figure $10 \mathrm{~cm}$ wide and $15 \mathrm{~cm}$ tall with upper end missing and vertical line drawn in center.

Cultural Materials Observed/Collected: None.

Shovel Test Data: None.

Assessment/Recommendations: Over $90 \%$ of aboriginal rock art appears intact; it contains features but lacks subsurface deposits. Aboriginal rock art has excellent research potential and is judged to be potentially eligible for listing on NRHP. Recommend detailed recording (see Table 37 ).

\section{GR495}

Location: Ca. $6.9 \mathrm{~km}$ ESE of Intersection of U.S. Highway 84 and FM 2458 , and $1.8 \mathrm{~km}$ NNE of confluence of Double Mountain Fork and Red Branch.

Description: Lithic procurement area on small point on upland margin at head of small drainage on north side of Double Mountain Fork; elevation 2240-2270 ft msl, area $1600 \mathrm{~m}^{2}$. Scatter of cores and debitage. Upper part of site bladed for construction of well pad; cultural materials seen on edge of upland margin and slightly downslope in eroded areas. Main part of site destroyed by well pad, with periphery of site remaining intact. Appears to have been lithic procurement area. No temporal components identifled; undefined Prehistoric.

Features: None. 
Cultural Materials Observed/Collected: Cores, core fragments, and debitage of Potter chert, local chert, and coarse-grained quartzite. No collections made.

Shovel Test Data: None.

Assessment/Recommendations: Less than $25 \%$ of site appears intact; it lacks subsurface deposits. Site has low research potentlal and is judged to be not eligible for listing on NRHP. No further work recommended.

\section{GR497}

Location: Ca. $7.0 \mathrm{~km}$ ESE of intersection of U.S. Highway 84 and FM 2458 , and $1.6 \mathrm{~km}$ NNE of confluence of Double Mountain Fork and Red Branch.

Description: Open campsite on large point on upland margin overlooking confluence of Double Mountain Fork and small side drainage; elevation $2260 \mathrm{ft} \mathrm{msl}$, area $62,500 \mathrm{~m}^{2}$. Site extends from eroded and deflated edge of canyon rim to upland plain above, where eolian deposits are preserved. Moderate to sparse scatter of chipped stone tools and debitage, mussel shell fragments, and burned rock fragments, with four burned rock features. Most materials found in eroded areas with slight concentration of materials in lower central part of site. Scatter is sparse in upland part of site, with few flakes in rodent burrows and ant mounds indicating intact subsurface deposits. Camping area with tool manufacture and faunal processing. No temporal components identified; undefined Prehistoric.

Features: Four clusters of burned sandstone range from 110 to $300 \mathrm{~cm}$ in diameter; found in eroded areas near edge of upland margin. May represent short-term fires as burned rocks are only slightly discolored.

Cultural Materials Observed/Collected: Drill and biface fragment of chert; scraper and chopper of Potter chert; flakes (secondary and tertiary) of Edwards chert, local chert, Potter chert, and coarse-grained quartzite; cobbles of coarse-grained quartzite; fragments of burned sandstone; and mussel shell fragment. Two 1tems collected (see Appendices A and B).

Shovel Test Data: One shovel test yielded mussel shell at $0-20 \mathrm{~cm}$ and indicated soil depth of at least $80 \mathrm{~cm}$.

Assessment/Recommendations: Over $90 \%$ of site appears intact; it contains features and subsurface deposits. Site has unknown research potentlal and is judged to be potentially eligible for listing on NRHP. Recommend controlled collection, mapping, and testing.

\section{GR503}

Location: Ca. $6.6 \mathrm{~km} \mathrm{SE}$ of intersection of U.S. Highway 84 and FM 2458 , and $0.3 \mathrm{~km} \mathrm{~N}$ of confluence of Double Mountain Fork and Red Branch. 
Description: Lithic procurement area on two small knolls surrounded by rocky terrace on upland ridge on north side of Double Mountain Fork; elevation 2240-2260 ft msl, area $5000 \mathrm{~m}^{2}$. Sparse scatter containing cores, tested cobbles, and debitage. Lithic procurement area used only slightly. No temporal components identified; undefined Prehistoric.

Features: None.

Cultural Materials Observed/Collected: Bifaclally flaked cobble of coarse-grained quartzite; cores, tested cobbles, and flakes of Potter chert and coarse-grained quartzite. No collections made.

Shovel Test Data: One negative shovel test indicated soil depth of $40 \mathrm{~cm}$.

Assessment/Recommendations: Over 90\% of site appears intact; it lacks subsurface deposits. Site has low research potential and is judged to be not eligible for listing on NRHP. No further work recommended.

\section{GR504}

Location: Ca. $6.3 \mathrm{~km} \mathrm{SE}$ of intersection of U.S. Highway 84 and FM 24.58, and $0.5 \mathrm{~km} \mathrm{NW}$ of confluence of Double Mountain Fork and Red Branch.

Description: Lithic procurement area/open campsite on bedrock terrace overlooking lower alluvial terrace of Double Mountain Fork; elevation 2220-2240 ft msl, area 45,000 m². Deposits of eolian sands and high-quality gravels on site. Artifact scatter with burned rock features. Cultural materials concentrated along lower edge of site in erosional exposure. Extensively disturbed by well pad and storage tank, two roads, and blading and leveling. Evidence of some surface collection. Camping area with numerous burned rocks and debitage, indicating long-term use and/or intensive occupation. Lithic procurement indicated by tested cobbles. Temporal component is late Archaic.

Features: Two definite features; one is ca. 35-cm-diameter cluster of burned Potter chert fragments, and other is ca. 50-cm-diameter cluster of burned sandstone slabs. Another concentration of burned rock fragments may have been a feature or features.

Cultural Materials Observed/Collected: Castroville dart point fragment; cores, tested cobbles, and debitage of Potter chert, local chert, Edwards chert, and coarse-grained quartzite; and burned fragments of sandstone and Potter chert. Seven 1tems collected (see Appendices $A$ and $B$ ).

Shovel Test Data: One shovel test yielded cultural materials between $40-120 \mathrm{~cm}$ and indicated soll depth of at least $120 \mathrm{~cm}$.

Assessment/Recommendations: Over $50 \%$ of site appears intact; it contains features and subsurface deposits. Site has excellent research potential and is judged to be potentially eligible for listing on NRHP. Recommend mapping and testing. 


\section{$\underline{41 G R 505}$}

Location: Ca. $6.1 \mathrm{~km} \mathrm{SE}$ of intersection of U.S. Highway 84 and FM 2458, and $0.5 \mathrm{~km}$ ENE of confluence of Double Mountain Fork and Sand Creek.

Description: Lithic procurement area on eroding ridge top and erosional remnant terrace on upland margin of Double Mountain Fork; elevation 2240-2260 ft msl, area 20,000 $\mathrm{m}^{2}$. Deflated and eroded area has little soll and great deal of Quaternary gravels on terrace. Lithic scatter with concentration of debitage and burned rocks corresponding with Quaternary gravel exposure. Half of ridge top destroyed by well pad. Lithic procurement area which was not used intensively, with evidence of related activities such as heat treatment. No temporal components identified; undefined Prehistoric.

Features: None.

Cultural Materials Observed/Collected: Cores, tested cobbles, and debitage of Potter chert and coarse-grained quartzite; few flakes of Edwards chert; fragments of burned Potter chert. No collections made.

Shove1 Test Data: None.

Assessment/Recommendations: Over $50 \%$ of site appears intact; it lacks subsurface deposits. Site has good research potential and is judged to be potentially eligible for listing on NRHP. Recommend controlled collection and mapping.

\section{$\underline{41 G R 506}$}

Location: Ca. $6.5 \mathrm{~km} \mathrm{SE}$ of intersection of U.S. Highway 84 and FM 2458, and $0.4 \mathrm{~km} \mathrm{NW}$ of confluence of Double Mountain Fork and Red Branch.

Description: Open campsite on top of erosional remnant mesa overlooking Double Mountain Fork; elevation 2260-2270 ft msl, area 12,500 $\mathrm{m}^{2}$. Mesa top has deep deposit of eolian sand. Sparse lithic scatter with burned rock concentrations and one definite feature on edges of mesa top where sand is eroding away. Undisturbed except for erosion and deflation. Activities represented are camping and limited lithic procurement. No temporal components Identified; undefined Prehistoric.

Features: Definite feature is large (ca. 150-cm-diameter) cluster of burned sandstone slabs. Other concentrations of burned Potter chert fragments and/or burned sandstone fragments may be disturbed features.

Cultural Materials Observed/Collected: Cores, tested cobbles, and debitage of Potter and Edwards chert and coarse-grained quartzite; some retouched Edwards chert flakes; fragments of burned Potter chert and sandstone. One item collected (see Appendices A and B).

Shovel Test Data: One shovel test yielded debitage at 0-20 cm and found soils to at least $100 \mathrm{~cm}$. 
Assessment/Recommendations: Over $75 \%$ of site appears intact; it contains features and subsurface deposits. Site has unknown research potential and is judged to be potentially eligible for listing on NRHP. Recommend mapping and testing.

\section{GR507}

Location: Ca. $6.5 \mathrm{~km}$ SW of intersection of U.S. Highway 84 and FM 2458 , and $0.2 \mathrm{~km} \mathrm{NW}$ of confluence of Double Mountain Fork and Red Branch.

Description: Lithic procurement area on bedrock terrace above floodplain of Double Mountain Fork; elevation 2220-2240 ft msl, area 22,500 $\mathrm{m}^{2}$. Terrace has considerable deposits of eolian and alluvial sand, with little evidence of erosion or deflation. Lithic scatter with one burned rock cluster. Concentration of artifacts in lower part of site near river measures ca. $40 \times 25 \mathrm{~m}$ and contains 2-m-diameter scatter of burned sandstone fragments, debitage, and scraper. Little-used lithic procurement area; feature could be associated with lithic procurement or later camping episode. No temporal components identified; undefined Prehistoric.

Features: Ca. 100-cm-dlameter cluster of burned sandstone cobbles and Potter chert fragments.

Cultural Materials Observed/Collected: Scraper, tested cobbles, and debitage of Potter chert, local chert, and coarse-grained quartzite; burned sandstone fragments. No collections made.

Shovel Test Data: One negative shovel indicated that solls are at least $85 \mathrm{~cm}$ deep.

Assessment/Recommendations: Less than $50 \%$ of site appears intact; it has features but may lack subsurface deposits. Site has low research potential and is judged to be not eligible for listing on NRHP. No further work recommended.

\section{$\underline{41 G R 509}$}

Location: Ca. $0.5 \mathrm{~km}$ WNW of confluence of Double Mountian Fork and Rocky Creek, and $1.2 \mathrm{~km}$ SSW of confluence of Double Mountain Fork and Gobbler Creek.

Description: Lithic procurement area/open campsite on edge of uplands at mouth of Rocky Creek; elevation 2220-2240 ft msl, area $9375 \mathrm{~m}^{2}$. Numerous drainages have formed ridges and points on edge of site. Scatter of tested cobbles and debitage, with burned rock scatters composed of fragments of sandstone and Potter chert. Dirt road at edge of site caused little disturbance; slight disturbance from erosion and deflation. Lithic procurement is primary activity, with some camping. No temporal components identified; undefined Prehistoric.

Features: None. 
Cultural Materials Observed/Collected: Tested cobbles and debitage of Potter chert, coarse-grained quartzite, and small amount of Edwards chert; fragments of burned Potter chert and sandstone. No collections made.

Shovel Test Data: One negative shovel test found soil depth of ca. $40 \mathrm{~cm}$.

Assessment/Recommendations: Over $50 \%$ of site appears intact; it lacks subsurface deposits. Site has no research potential and is judged to be not eligible for listing on NRHP. No further work recommended.

\section{GR511}

Location: Ca. $1.7 \mathrm{~km}$ NNE of confluence of Double Mountain Fork and Red Branch, and $6.8 \mathrm{~km}$ ESE of U.S. Highway 84 bridge over Double Mountain Fork.

Description: Lithic procurement area/open campsite on upland nargin overlooking small side drainage of Double Mountain Fork; elevation 2240-2270 ft msl, area 37,500 $\mathrm{m}^{2}$. Dissected by several small drainages into four deflated finger ridges, with small gravels exposed on surface. Very sparse scatter of lithic artifacts, with seven burned rock features. Cultural materials concentrated on ridge at mouth of side drainage and almost absent from other ridges. Main ridge is most eroded, with most burned rock features. Site possibly has been surface collected. Essentially a camping area, with plant processing and lithic procurement. No temporal components identified; undefined Prehistoric.

Features: Seven small (ca. 50-75-cm-diameter) clusters of burned sandstone; three on main ridge and four on other ridges.

Cultural Materials Observed/Collected: Biface fragment, mano, cores, and tested cobbles of Potter chert, local chert, coarse-grained quartzite, and Edwards chert, with fragments of burned sandstone and Potter chert. No collections made.

Shovel Test Data: One negative shovel test found soil depth of at least $100 \mathrm{~cm}$ on main ridge.

Assessment/Recommendations: Over $50 \%$ of site appears intact; it contains features but has little potential for subsurface deposits. Site has low research potential and is judged to be not eligible for listing on NRHP. No further work recommended.

\section{GR512}

Location: Ca. $4.9 \mathrm{~km} \mathrm{NE}$ of U.S. Highway 84 bridge over Sand Creek, and $6.7 \mathrm{~km}$ ESE of U.S. Highway 84 bridge over Double Mountain Fork.

Description: Faunal locality in cutbank of 3-m-deep erosional gully cutting through lower alluvial terrace above Double Mountain Fork; elevation 2200-2220 ft msl, area $4 \mathrm{~m}^{2}$. Bison $\mathrm{rib}$ fragment and small flecks of charcoal found in cutbank. Charcoal flecks ranged from 47 to $55 \mathrm{~cm}$ below surface; bison bone was at $60 \mathrm{~cm}$. Charcoal extended ca. $250 \mathrm{~cm}$ 
along cutbank. Troweling and soil screening of cutbank yielded no evidence of cultural activity, but shovel test above bone fragment recovered core. Could be remains of prehistoric bison kill despite scarcity of cultural materials. No temporal components identified; undefined Prehistoric.

Features: None.

Cultural Materials Observed/Collected: Tested core of silicified wood, fragment of bison rib bone, few small unidentifiable bone fragments, and few flecks of charcoal. One item collected (see Appendices A and B).

Shovel Test Data: One shovel test on terrace surface $1 \mathrm{~m}$ in from bone fragment ylelded tested core at $40 \mathrm{~cm}$ and indicated soil depth is at least $100 \mathrm{~cm}$.

Assessment/Recommendations: Integrity of site is unknown; it contains subsurface deposits. Site has good research potential and is judged to be potentially eligible for listing on NRHP. Recommend mapping and testing.

\section{$41 \mathrm{GR} 513$}

Location: Ca. $1.8 \mathrm{~km} \mathrm{NE}$ of confluence of Double Mountain Fork and Red Branch, and 6.7 km ESE of U.S. Highway 84 bridge over Double Mountain Fork.

Description: Lithic scatter on eroded upland ridge forming point overlooking Double Mountain Fork; elevation $2280 \mathrm{ft} \mathrm{msl}$, area $140 \mathrm{~m}^{2}$. Point is deflated and eroded. Small sparse scatter of lithic materials. Site is probably result of limited testing of cobbles on point. No temporal components identified; undefined Prehistoric.

Features: None.

Cultural Materials Observed/Collected: Large utilized flake, core, four tested cobbles, and few flakes, all of Potter chert. No collections made.

Shovel Test Data: None.

Assessment/Recommendations: Over $90 \%$ of site appears intact; it lacks subsurface deposits. Site has low research potential and is judged to be not eligible for listing on NRHP No further work recommended.

\section{$41 \mathrm{GR} 514$}

Location: Ca. $6.5 \mathrm{~km}$ ESE of U.S. Highway 84 bridge over Double Mountain Fork, and 4.6 km NE of U.S. Highway 84 bridge over Sand Creek.

Description: Open campsite on small upland point on eroding canyon rim above Double Mountain Fork; elevation $2260 \mathrm{ft} \mathrm{msl}$, area $600 \mathrm{~m}^{2}$. Erosional drainages on both sides of point, which is deflated and eroded at edges. Single core tool and debitage concentrated 
around two burned rock features. Disturbed somewhat by brush clearing and some bulldozing. Small camping area with some tool manufacture. No temporal components identified; undefined Prehistoric.

Features: Two small burned rock features; one is ca. 100-cm-diameter cluster of slightly burned sandstone fragments and few flakes, and other is ca. 50-cm-diameter cluster of burned limestone fragments and debitage.

Cultural Materlals Observed/Collected: Core or chopper of Potter chert, secondary and tertiary flakes of Potter and Edwards chert and coarse-grained quartzite, and few fragments of burned rocks. No collections made.

Shovel Test Data: One negative shovel test indlcated soil depth of ca. $80 \mathrm{~cm}$.

Assessment/Recommendations: Over $90 \%$ of site appears intact; it contains features but lacks subsurface deposits. Site has moderate research potential and is judged to be potentially eligible for listing on NRHP. Recommend mapping and testing.

\section{$\underline{41 G R 515}$}

Location: Ca. $1.0 \mathrm{~km}$ NNE of confluence of Double Mountain Fork and Red Branch, and $7.0 \mathrm{~km}$ ESE of intersection of U.S. Highway 84 and FM 2458.

Description: Lithic procurement area/open campsite on erosional remnant terrace above floodplain of Double Mountain Fork; elevation $2220 \mathrm{ft} \mathrm{ms} 1$, area 15,000 $\mathrm{m}^{2}$. Several small drainages dissect rises and expose gravelly soil; other areas contain alluvial or eolian sand deposits. Dense scatter of cultural materials with two features. Also, burned sandstone fragments are concentrated in three ca. 5-10-m-diameter areas near lower edge of terrace. Dirt road cuts through one end of site; one feature was noted in roadcut. Other than dirt road and erosion, site appears undisturbed. Campsite used intensively for short period of time or intermittently for longer. Lithic procurement evident, but not main function. Temporal component is Late Prehistoric.

Features: Two distinct features. One is ca. 100-cm-diameter cluster of burned sandstone fragments which appears to be hearth; other is ca. 100-cm-diameter cluster of burned sandstone slabs and charcoal in road cut at $130 \mathrm{~cm}$ below surface which appears to be slablined hearth.

Cultural Materials Observed/Collected: Harrell arrow point, scraper, mano, hammerstone, cores, tested cobbles, and debitage of Potter and Edwards chert, local chert, and coarse-grained quartzite; and fragments of burned sandstone and Potter chert. Six items, including one charcoal sample, collected (see Appendices A and B).

Shovel Test Data: Two shovel tests excavated, one near each feature. Negative test near burned rock cluster indicated soil depth of ca. $100 \mathrm{~cm}$. Test near slab-lined hearth yielded cultural materials at $0-20,40-60$, and $155 \mathrm{~cm}$ below surface. Soil depth is at least $160 \mathrm{~cm}$, and cutbank is ca. $250 \mathrm{~cm}$ high. 
Assessment/Recommendations: Over $75 \%$ of site appears intact; it contains features and subsurface deposits. Site has good research potential and is judged to be potentially eligible for listing on NRHP. Recommend controlled collection, mapping, and testing.

$\underline{41 G R 517}$

Location: Ca. $5.9 \mathrm{~km}$ SSE of U.S. Highway 84 bridge over Double Mountain Fork, and 0.4 $\mathrm{km}$ SSE of confluence of Double Mountain Fork and Red Branch.

Description: Rock art site in rock cleft eroded from side of isolated mesa within mouth of Red Branch; elevation $2270 \mathrm{ft} \mathrm{msl}$, area $10 \mathrm{~m}^{2}$. Cleft is ca. $5 \mathrm{~m}$ deep, $2 \mathrm{~m} \mathrm{high}$, and $1.5 \mathrm{~m}$ wide; rock floor slopes steeply upward toward narrow back of cleft. On one wall are names and initials with historic to recent dates, and one element of rock art which may be aboriginal (see Fig. 34a). No evidence of occupation in or around cleft. Temporal components are undefined Prehistoric and Historic (see Appendix G for description of historic component).

Features: Possible aboriginal element is petroglyph composed of two perpendicular intersecting lines; horizontal line has barbed point like an arrow on right end.

Cultural Materials Observed/Collected: None.

Shovel Test Data: None.

Assessment/Recommendations: Over $90 \%$ of aboriginal rock art appears intact; it lacks associated subsurface deposits. Aboriginal rock art has moderate research potential and is judged to be potentially eligible for listing on NRHP. However, no further work recommended because rock art is so simplistic that current records are adequate.

\section{GR518}

Location: Ca. $1.3 \mathrm{~km}$ ESE of confluence of Double Mountain Fork and Sand Creek, and $3.1 \mathrm{~km} \mathrm{NE}$ of U.S. Highway 84 bridge over Sand Creek.

Description: Open campsite on bedrock terrace and lower alluvial terrace at confluence of Double Mountain Fork and Red Branch; elevation 2200-2220 ft msl, area $5000 \mathrm{~m}^{2}$. Sparse scatter of debitage and burned rocks, with mano. Burned rocks and few flakes scattered on lower alluvial terrace, while bedrock terrace contains most of debitage. Alluvial terrace extensively disturbed by well pad and blading; bedrock terrace is eroded and deflated. Scattered burned rocks indicate that features were present; site may have been camping area. No temporal components identified; undefined Prehistoric.

Features: None.

Cultural Materials Observed/Collected: Sandstone mano and tertiary flakes of Edwards chert. No collections made. 
Shovel Test Data: One negative shovel test on lower alluvial terrace found soll depth of at least $50 \mathrm{~cm}$.

Assessment/Recommendations: Over $50 \%$ of site appears intact; it lacks subsurface deposits. Site has no research potential and is judged to be not eligible for listing on NRHP. No further work recommended.

\section{$\underline{41 G R 520}$}

Location: Ca. $2.0 \mathrm{~km}$ ENE of U.S. Highway 84 bridge over Sand Creek, and $1.3 \mathrm{~km}$ SSW of confluence of Double Mountain Fork and Red Branch.

Description: Lithic procurement area on isolated bedrock terrace within point bar of Red Branch; elevation $2240 \mathrm{ft} \mathrm{msl}$, area $1750 \mathrm{~m}^{2}$. Terrace has considerable deposit of eollan sands with few gravels exposed on surface. Small, sparse lithic scatter. Site could represent occasional testing of cobbles or possibly single camping episode. No temporal components identified; undefined Prehistoric.

Features: None.

Cultural Materials Observed/Collected: Scraper, core, and seven flakes of Potter chert and local chert. No collections made.

Shovel Test Data: One negative shovel test indicated soil depth of ca. $50 \mathrm{~cm}$.

Assessment/Recommendations: Over $50 \%$ of site appears intact; it lacks subsurface deposits. Site has low research potential and is judged to be not eligible for listing on NRHP. No further work recommended.

\section{$\underline{41 G R 521}$}

Location: Ca. $2.4 \mathrm{~km}$ ENE of U.S. Highway 84 bridge over Sand Creek, and $0.8 \mathrm{~km}$ SSW of confluence of Double Mountain Fork and Red Branch.

Description: Lithic scatter on lower alluvial terrace within bend in Red Branch; elevation $2220 \mathrm{ft} \mathrm{msl}$, area $2500 \mathrm{~m}^{2}$. Some eolian deposition on upper end of terrace; lower end is deflated and has exposures of small gravels. Small lithic scatter. Site possibly is plant procurement and processing area. No temporal components identified; undefined Prehistoric.

Features: None.

Cultural Materials Observed/Collected: Two quartzite manos, Edwards chert scraper, and few flakes of local chert. Two items collected (see Appendices A and B).

Shovel Test Data: One negative shovel test in eolian deposit indicated soil depth of ca. $16 \mathrm{~cm}$. 
Assessment/Recommendations: Less than $50 \%$ of site appears intact; it lacks subsurface deposits. Site has low research potential and is judged to be not eligible for listing on NRHP. No further work recommended.

\section{$\underline{41 G R 523}$}

Location: Ca. $2.4 \mathrm{~km} \mathrm{NE}$ of U.S. Highway 84 bridge over Sand Creek, and $0.8 \mathrm{~km} \mathrm{~W}$ of confluence of Double Mountain Fork and Red Branch.

Description: Open campsite on eroding upland ridge with small hill and bench above Double Mountain Fork; elevation 2260-2280 ft msl, area 20,000 $\mathrm{m}^{2}$. Moderate amount of gravel exposed on site. Lithic scatter with abundant burned rocks, suggesting that features were present. Most cultural materials on hill. Disturbed by well pad, bladed area covered with fill, and earth berm. Camping, with lithic reduction one of main activities. No temporal components identified; undefined Prehistoric.

Features: None (however, see Shovel Test Data).

Cultural Materials Observed/Collected: Potter chert chopper; cores and flakes of Potter and Edwards chert, local chert, and coarse-grained quartzite; and fragments of burned Potter chert and sandstone. Four items collected (see Appendices C and D).

Shovel Test Data: One shovel test on hill yielded cultural materials from $20-100 \mathrm{~cm}$ with possible burned rock feature encountered between 20-60 cm; soils were at least $105 \mathrm{~cm}$ deep.

Assessment/Recommendations: Over 50\% of site appears intact; it contains subsurface deposits and may have features. Site has good research potential and is judged to be potentially eligible for listing on NRHP. Recommend mapping and testing.

\section{GR524}

Location: Ca. $2.4 \mathrm{~km}$ NNE of U.S. Highway 84 bridge over Sand Creek, and $0.4 \mathrm{~km}$ ESE of confluence of Double Mountain Fork and Sand Creek.

Description: Lithic procurement area on upland ridge at confluence of Double Mountain Fork and small side drainage; elevation 2260-2280 ft msl, area $7500 \mathrm{~m}^{2}$. Top of ridge deflated, leaving thin soil deposit over gravels exposed in several areas. Lithic scatter with few burned rocks. Lithic procurement area, although not used extensively. Burned rocks could be related to heat treatment. No temporal components identified; undefined Prehistoric.

Features: None.

Cultural Materials Observed/Collected: Possible chopper of Potter chert; cores, tested cobbles, and flakes of Potter chert and coarse-grained quartzite; and burned rock fragments of Potter chert. No collections made. 
Shovel Test Data: One negative shovel test indicated soll depth of $30 \mathrm{~cm}$.

Assessment/Recommendations: Over $50 \%$ of site appears intact; it lacks subsurface deposits. Site has low research potential and is judged to be not eligible for listing on NRHP. No further work recommended.

41GR527

Location: Ca. $5.8 \mathrm{~km} \mathrm{SE}$ of intersection of U.S. Highway 84 and FM 2458, and $2.6 \mathrm{~km} \mathrm{NE}$ of U.S. Highway 84 bridge over Sand Creek.

Description: Lithic procurement area/open campsite on sandstone terrace above Double Mountain Fork; elevation 2220-2240 ft msl, area $60,000 \mathrm{~m}^{2}$. Terrace dissected by erosional drainages contains substantial gravel deposit covered by thin eolian sands. Lithic scatter of tested cobbles, debitage, and burned Potter chert nodules. Much material seen on surface of erosional areas. Lithic procurement area with some evidence of habitation. No temporal components identified; undefined Prehistoric.

Features: None.

Cultural Materials Observed/Collected: Tested cobbles and chipping debris of Potter chert, coarse-grained quartzite, and local chert, with some burned Potter chert cobbles. No collections made.

Shovel Test Data: Two negative shovel tests. One near base of bluff indicated soil depth of $\mathrm{ca} .34 \mathrm{~cm}$; other near lower edge of terrace Indicated soil depth of at least 100 $\mathrm{cm}$.

Assessment/Recommendations: Over 50\% of site appears intact; it may contain subsurface deposits. Site has unknown research potential and is judged to be potentially eligible for listing on NRHP. Recommend mapping and testing.

\section{GR528}

Location: Ca. $1.7 \mathrm{~km}$ SW of confluence of Double Mountain Fork and Sand Creek, and 0.7 $\mathrm{km} \mathrm{N}$ of U.S. Highway 84 bridge over Sand Creek.

Description: Open campsite on gravel-capped erosional remnant terrace overlooking Sand Creek; elevation 2240-2260 ft msl, area 10,000 $\mathrm{m}^{2}$. Surface of terrace deflated; exposed gravels are small and not 11thic source. Historic component on site, with grave and light historic trash scatter. Major component is prehistoric lithic scatter, with two burned rock features and small concentration of burned sandstone and limestone fragments. Small camping area. Temporal components are undefined Prehistoric and Historic (see Appendix G for description of historic component).

Features: Two features; one is ca. 50-cm-diameter cluster of burned sandstone fragments with alternately beveled biface $3 \mathrm{~m}$ away, and other is ca. 75-cm-diameter possible slab-lined hearth with chopper nearby. 
Cultural Materials Observed/Collected: Alternately beveled biface fragment of Edwards chert, chopper of Potter chert, cores and battered cobbles of Potter chert, flakes of Potter chert and Edwards chert, and battered cobbles of coarse-grained quartzite. No collections made.

Shovel Test Data: One shovel test revealed burned rocks from $0-50 \mathrm{~cm}$ and indicated soil depth of ca. $50 \mathrm{~cm}$.

Assessment/Recommendations: Over 50\% of prehistoric component appears intact; it contains features and subsurface deposits. Prehistoric component has good research potential and is judged to be potentially eligible for listing on NRHP. Recommend controlled collection, mapping, and testing.

\section{GR529}

Location: Ca. $0.64 \mathrm{~km}$ NNW of U.S. Highway 84 bridge over Sand Creek, and $1.9 \mathrm{~km} \mathrm{SW}$ of confluence of Double Mountain Fork and Sand Creek.

Description: Open campsite on lower alluvial terrace over Sand Creek between two small erosional gullies; elevation 2230-2245 ft $\mathrm{msl}$, area 22,500 $\mathrm{m}^{2}$. Scatter of chipped stone tools, debitage, bison bone fragments, mussel shell fragments, and fragments of burned sandstone, with few diffuse clusters and one definite burned rock feature in cutbanks of gullies. Extensively eroded except for small ridges between gullies. Campsite associated with bison hunting and limited procurement of other resources. No temporal components identified; undefined Prehistoric.

Features: Ca. 30-cm-long and 10-cm-thick clustex of large burned sandstone cobbles just below surface in cutbank.

Cultural Materials Observed/Collected: Three scrapers of Edwards chert, flakes of Edwards and Potter chert, mussel shell fragments, bison bone fragments, and fragments of burned sandstone. One item collected (see Appendices A and B).

Shovel Test Data: None.

Assessment/Recommendations: Over 75\% of site appears intact; it contains features but may lack subsurface deposits. Site has unknown research potential and is judged to be potentially eligible for listing on NRHP. Recommend mapping and testing.

\section{GR531}

Location: Ca. $0.3 \mathrm{~km} \mathrm{~N}$ of U.S. Highway 84 bridge over Sand Creek, and $2.0 \mathrm{~km}$ SSW of confluence of Double Mountain Fork and Sand Creek.

Description: Open campsite on small bedrock rise on lower alluvial terrace above Sand Creek; elevation $2230 \mathrm{ft} \mathrm{msl}$, area $1500 \mathrm{~m}^{2}$. Terrace covered with thin deposit of eolian sand. Very sparse scatter of debitage, with one definite feature and two burned sandstone 
clusters which could be eroded features. Small camping area with some tool manufacture. No temporal components identified; undefined Prehistoric.

Features: Definite feature is cluster of burned sandstone fragments, with tertiary flakes and possible utilized flake of Edwards chert.

Cultural Materials Observed/Collected: Flakes and possible utilized flake of Edwards chert, and fragments of burned sandstone. No collections made.

Shovel Test Data: One negative shovel test indicated soil depth of ca. $30 \mathrm{~cm}$.

Assessment/Recommendations: Over $75 \%$ of site appears intact; it contains features but lacks subsurface deposits. Site has no research potential and is judged to be not eligible for listing on NRHP. No further work recommended.

\section{GR533}

Location: Ca. $1.0 \mathrm{~km}$ SW of confluence of Double Mountain Fork and Sand Creek, and 1.6 $\mathrm{km}$ NNE of U.S. Highway 84 bridge over Sand Creek.

Description: Open campsite on upland margin in deflated and eroding area of canyon rim overlooking Sand Creek; elevation $2245 \mathrm{ft} \mathrm{msl}$, area $2400 \mathrm{~m}^{2}$. Edge of rim dissected by four small gullies, and small gravels are exposed on surface. Sparse lithic scatter with two burned rock clusters; most cultural materials found near erosional areas. Small campsite with some plant processing. No temporal components identified; undefined Prehistoric.

Features: Two small clusters of burned sandstone, both ca. $75 \mathrm{~cm}$ in diameter.

Cultural Materials Observed/Collected: One quartzite mano, modified flake of local chert, flakes of Edwards and local chert, and fragments of burned Potter chert and sandstone. No collections made.

Shovel Test Data: One negative shovel test indicated soil depth of ca. $60 \mathrm{~cm}$.

Assessment/Recommendations: Over $75 \%$ of site appears intact; it contains features but lacks subsurface deposits. Site has no research potential and is judged to be not eligible for listing on NRHP. No further work recommended.

\section{GR534}

Location: Ca. $3.9 \mathrm{~km} \mathrm{SE}$ of U.S. Highway 84 bridge over Double Mountain Fork, and 2.1 $\mathrm{km}$ NNE of U.S. Highway 84 bridge over Sand Creek.

Description: Lithic procurement area on upland margin in eroded area of canyon rim overlooking Sand Creek; elevation 2240-2260 ft msl, area $5000 \mathrm{~m}^{2}$. Eroded knoll with bedrock terrace below, covered with thin deposit of eolian sands over Quaternary gravels. Sparse scatter of tested cobbles and small amount of debitage. Small-scale exploitation of 
gravel deposit as lithic procurement area. No temporal components identified; undefined Prehistoric.

Features: None.

Cultural Materials Observed/Collected: Tested cobbles and flakes of Potter chert, Edwards chert, and red coarse-grained quartzite. No collections made.

Shovel Test Data: None.

Assessment/Recommendations: Over $75 \%$ of site appears intact; it lacks subsurface deposits. Site has low research potential and is judged to be not eligible for listing on NRHP. No further work recommended.

\section{GR538}

Location: Ca. $4.0 \mathrm{~km}$ SSE of U.S. Highway 84 bridge over Double Mountain Fork, and 0.8 km NNW of confluence of Double Mountain Fork and Sand Creek.

Description: Lithic procurement area on erosional remnant terrace on valley slopes above unnamed drainage north of Sand Creek; elevation 2200-2240 ft msl, area $6000 \mathrm{~m}^{2}$. Eroded and deflated area with outcrop of Quaternary gravels on surface. Scatter of tested cobbles and debitage. Little-used lithic procurement area. No temporal components identified; undefined Prehistoric.

Features: None.

Cultural Materials Observed/Collected: Tested cobbles and few flakes of Potter chert, red coarse-grained quartzite, Edwards chert, silicified wood, and local chert. No collections made.

Shovel Test Data: None.

Assessment/Recommendations: Over $75 \%$ of site appears intact; it lacks subsurface deposits. Site has good research potential and is judged to be potentially eligible for listing on NRHP. Recommend controlled collection and mapping.

\section{$\underline{41 G R 539}$}

Location: Ca. $4.8 \mathrm{~km}$ ESE of intersection of U.S. Highway 84 and FM 2458, and $3.1 \mathrm{~km}$ NNW of U.S. Highway 84 bridge over Sand Creek.

Description: Faunal locality in cutbank of unnamed drainage north of Sand Creek; elevation $2220 \mathrm{ft} \mathrm{msl}$, area $25 \mathrm{~m}^{2}$. Articulated vertebral column and toe bones of bison found in cutbank ca. 120-160 cm below surface. Face of cutbank was troweled and screened, but no evidence of cultural activity. Bones could represent bison kill but no definite evidence of this. No temporal components identified; undefined Prehistoric. 
Features: None.

Cultural Materials Observed/Collected: Bison ribs, vertebrae, and toe bones. Two items collected (see Appendices A and B).

Shovel Test Data: None.

Assessment/Recommendations: Integrity of site unknown; it contains subsurface deposits. Site has good research potential and is judged to be potentially eligible for listing on NRHP. Recommend controlled collection and mapping.

\section{GR540}

Location: Ca. $4.6 \mathrm{~km}$ ESE of intersection of U.S. Highway 84 and FM 2458 , and $1.5 \mathrm{~km}$ NNW of confluence of Double Mountain Fork and Sand Creek.

Description: Lithic procurement area on bedrock terrace covered with Quaternary gravels and thin deposit of eolian sands above unnamed drainage north of Sand Creek; elevation $2260 \mathrm{ft} \mathrm{msl}$, area $4375 \mathrm{~m}^{2}$. Small erosional gullies dissect terrace, forming points overlooking drainage. Lithic scatter closely follows gravel outcrop. Large lithic procurement area used more extensively than 41GR538 downstream. No temporal components identified; undefined Prehistoric.

Features: None.

Cultural Materials Observed/Collected: Cores, tested cobbles, and flakes of Potter chert, coarse-grained quartzite, and some local chert; few flakes and fragments of possibly burned Potter chert. No collections made.

Shovel Test Data: None.

Assessment/Recommendations: Over $75 \%$ of site appears intact; it lacks subsurface deposits. Site has good research potential and is judged to be potentially eligible for listing on NRHP. Recommend controlled collection and mapping.

\section{GR541}

Location: Ca. $4.9 \mathrm{~km}$ ESE of intersection of U.S. Highway 84 and FM 2458 , and $1.0 \mathrm{~km} \mathrm{~N}$ of confluence of Double Mountain Fork and Sand Creek.

Description: Lithic procurement area/open campsite on erosional remnant terrace sloping to unnamed drainage north of Sand Creek; elevation 2220-2240 ft msl, area 11,250 $\mathrm{m}^{2}$. Small rise on upstream end of site has outcrop of Quaternary gravels; surface is level and uneroded. Lower terrace is deflated and eroded. Lithic scatter with several burned rock features and concentrations on lower terrace in deflated and eroded area. Evidence of lithic procurement on upper part of terrace on rise. Burned rock features and grinding stones are evidence that site was camping area with plant processing. Good chance for buried cultural deposits in eolian deposits on top of hill. Temporal component is Archaic. 
Features: Burned rock features and concentrations. Three definite features are clusters ca. $100 \mathrm{~cm}$ in diameter of burned sandstone fragments believed to be remains of hearths. Concentrations are small, ca. 100-150 cm in diameter, and contain few burned rock fragments.

Cultural Materials Observed/Collected: Untyped dart point of Edwards chert, two manos and a metate fragment of sandstone, chopper of Potter chert, few flakes of Potter chert, and fragments of burned Potter chert and sandstone. One item collected (see Appendices A and $\mathrm{B})$.

Shovel Test Data: One negative shovel test found soils at back of lower terrace are at least $94 \mathrm{~cm}$ deep.

Assessment/Recommendations: Over $90 \%$ of site appears intact; it contains features and may have subsurface deposits. Site has good research potential and is judged to be potentially eligible for listing on NRHP. Recommend controlled collection, mapping, and testing.

\section{GR542}

Location: Ca. $3.1 \mathrm{~km}$ NNE of U.S. Highway 84 bridge over Sand Creek, and $3.7 \mathrm{~km}$ ESE of U.S. Highway 84 bridge over Double Mountain Fork.

Description: Lithic procurement area along erosional remnant terrace above unnamed drainage north of Sand Creek; elevation $2260 \mathrm{ft} \mathrm{msl}$, area 18,000 $\mathrm{m}^{2}$. Terrace dissected by small drainages forming points overlooking drainage; thin deposit of eolian sand over outcrop of Quaternary gravels. Lithic scatter corresponding with gravel outcrop, as at 41 GR540 which is located directly across drainage. Evidence of considerable amount of use. No temporal components identified; undefined Prehistoric.

Features: None.

Cultural Materials observed/Collected: Cores, tested cobbles, and flakes of Potter chert, local chert, and coarse-grained quartzite, with few flakes of heat-treated Potter chert. No collections made.

Shovel Test Data: None.

Assessment/Recommendations: Over $75 \%$ of site appears intact; it lacks subsurface deposits. Site has good research potential and is judged to be potentially eligible for listing on NRHP. Recommend controlled collection and mapping.

\section{$41 \mathrm{GR} 543$}

Location: Ca. $5.0 \mathrm{~km}$ ESE of intersection of U.S. Highway 84 and FM 2458 , and $1.1 \mathrm{~km}$ NNW of confluence of Double Mountain Fork and Sand Creek. 
Description: Open campsite on small erosional remnant bench overlooking unnamed drainage north of Sand Creek; elevation 2220-2240 ft msl, area $7500 \mathrm{~m}^{2}$. Bench is deflated; gravels exposed over much of surface. Light scatter of lithic artifacts with two burned rock features. Disturbed slightly by dirt road which cuts through site's lower edge. Small camping area with plant processing activities represented. No temporal components identified; undefined Prehistoric.

Features: Two burned rock features. One is ca. 100-cm-diameter cluster of burned Potter chert fragments with chopper nearby, which may be boiling stone dump. Other is cluster of burned sandstone fragments, also $100 \mathrm{~cm}$ in diameter, which may be hearth, with sandstone mano fragment nearby.

Cultural Materials Observed/Collected: Two sandstone mano fragments, two metate fragments, Potter chert chopper, debitage of Potter chert and coarse-grained quartzite, and fragments of burned Potter chert and sandstone. Three items collected (see Appendices A and B).

Shovel Test Data: One shovel test yielded cultural materials from 0-20 cm and found soils at least $70 \mathrm{~cm}$ deep.

Assessment/Recommendations: Over $50 \%$ of site appears intact; it contains features and subsurface deposits. Site has unknown research potential and is judged to be potentially eligible for listing on NRHP. Recommend controlled collection, mapping, and testing.

41 GR544

Location: Ca. $4.8 \mathrm{~km}$ ESE of intersection of U.S. Highway 84 and FM 2458, and $1.3 \mathrm{~km}$ NNW of confluence of Double Mountain Fork and Sand Creek.

Description: Lithic procurement area/open campsite on bedrock terrace and lower erosional remnant terrace below it overlooking unnamed drainage north of Sand Creek; elevation $2240 \mathrm{ft} \mathrm{msl}$, area $3750 \mathrm{~m}^{2}$. Upper bedrock terrace has thin deposit of colluvium and eolian sand over Quaternary gravels. Lower terrace covered with colluvium and gravels. Very light scatter of lithic artifacts with cluster of possibly burned sandstone fragments. Site is eroded and deflated. Main activity represented is lithic procurement, with some camping and plant processing. No temporal components identified; undefined Prehistoric.

Features: Cluster ca. $100 \mathrm{~cm}$ in diameter of sandstone cobbles which may have been burned; scattered by erosion.

Cultural Materials Observed/Collected: Two choppers of Potter chert; sandstone mano; and debitage of Potter chert, coarse-grained quartzite, and local chert. One item collected (see Appendices A and B).

Shovel Test Data: None.

Assessment/Recommendations: Over $75 \%$ of site appears intact; it contains features but lacks subsurface deposits. Site has no research potential and is judged to be not eligible for listing on NRHP. No further work recommended. 
Location: Ca. $5.0 \mathrm{~km}$ ESE of Intersection of U.S. Highway 84 and FM 2458 , and $0.8 \mathrm{~km}$ NNW of confluence of Double Mountain Fork and Sand Creek.

Description: Rock art site on tall vertical sandstone face beneath large overhang on bluff overlooking Double Mountain Fork; elevation 2260-2280 ft msl, area $100 \mathrm{~m}^{2}$. Rock face is ca. $20 \mathrm{~m}$ long and $5 \mathrm{~m}$ high; bench area below rock face is ca. $2 \mathrm{~m}$ wide. Large number of historic inscriptions with single aboriginal petroglyph (see Fig. 34b). Temporal components are undefined Prehistoric and Historic (see Appendix G for description of historic component).

Features: Aboriginal petroglyph ca. $35 \mathrm{~cm}$ long and $25 \mathrm{~cm}$ tall is complex pattern of interconnected cruciforms with rhombohedron at center. Six cruciforms extend from outer edges of glyph (four on top and two on bottom) and are somewhat similar to swastika pattern.

Cultural Materials Observed/Collected: None.

Shovel Test Data: None.

Assessment/Recommendations: Over $75 \%$ of aboriginal petroglyph appears intact; it lacks assoclated subsurface deposits. Aboriginal petroglyph has excellent research potential and is judged to be potentlally eligible for listing on NRHP. Recommend detailed recording (see Table 37 ).

\section{$\underline{41 \mathrm{GR} 546}$}

Location: Ca. $5.3 \mathrm{~km}$ ESE of intersection of U.S. Highway 84 and FM 2458 , and $0.7 \mathrm{~km}$ NNW of confluence of Double Mountain Fork and Sand Creek.

Description: Rockshelter in bluff over unnamed drainage north of Sand Creek; elevation $2250 \mathrm{ft} \mathrm{msl}$, area $7.8 \mathrm{~m}^{2}$. Shelter eroded out of sandstone is ca. $3.0 \mathrm{~m} \mathrm{wide,} 2.6 \mathrm{~m}$ deep, and $1.3 \mathrm{~m} \mathrm{high.} \mathrm{Floor} \mathrm{has} \mathrm{deposit} \mathrm{of} \mathrm{sand} \mathrm{and} \mathrm{sandstone} \mathrm{fragments} \mathrm{fallen} \mathrm{from} \mathrm{roof,}$ containing cultural materials. Small amount of materials on surface of shelter floor. Dark charcoal stain on roof of shelter appears to be soot from fires. No temporal components 1dentified; undefined Prehistoric.

Features: None.

Cultural Materlals Observed/Collected: Possibly modified flake of local chert, debitage of local chert and silicified wood, and fragments of burned Potter chert and limestone. Eight items collected (see Appendices A and B).

Shovel Test Data: One shovel test yielded cultural materials at 20-40 cm and found soils ca. $54 \mathrm{~cm}$ deep. 
Assessment/Recommendations: Over $90 \%$ of site appears intact; it contains subsurface deposits. Site has good research potential and is judged to be potentially eligible for listing on NRHP. Recommend mapping and testing.

\section{$41 \mathrm{GR} 547$}

Location: Ca. $4.9 \mathrm{~km}$ ESE of intersection of U.S. Highway 84 and FM 2458 , and $0.9 \mathrm{~km}$ NNW of confluence of Double Mountain Fork and Sand Creek.

Description: Lithic procurement area on erosional remnant terrace just below upland margin of eroding ridge overlooking Double Mountain Fork; elevation 2240-2260 ft msl, area $5000 \mathrm{~m}^{2}$. Area is deflated and has small outcrop of Quaternary gravels. Scatter of tested cobbles and debitage. Disturbed slightly by dirt road which runs along upper edge and barbed wire fence which runs through center of site. Materials probably scattered through erosion and deflation. Small lithic procurement area with minimal usage. No temporal components identified; undefined Prehistoric.

Features: None.

Cultural Materials Observed/Collected: Tested cobbles and debitage of Potter chert and purple coarse-grained quartzite. No collections made.

Shovel Test Data: None.

Assessment/Recommendations: Over $75 \%$ of site appears intact; it lacks subsurface deposits. Site has low research potential and is judged to be not eligible for listing on NRHP. No further work recommended.

\section{GR548}

Location: Ca. $4.5 \mathrm{~km}$ ESE of intersection of U.S. Highway 84 and FM 2458 , and $1.2 \mathrm{~km}$ NNW of confluence of Double Mountain Fork and Sand Creek.

Description: Lithic procurement area in deflated area with small exposure of Quater nary gravels on upland margin overlooking Double Mountain Fork; elevation $2280 \mathrm{ft} \mathrm{msl}$, area $10,625 \mathrm{~m}^{2}$. Scatter of lithic artifacts following gravel outcrop along canyon rim, with tested cobbles in areas of chippable gravels. Lithic procurement area with evidence of moderate use and possibly heat treatment. No temporal components identified; undefined Prehistoric.

Features: None.

Cultural Materials Observed/Collected: Cores, tested cobbles, and debitage of Potter chert, coarse-grained quartzite, and local chert, and few fragments of burned Potter chert. No collections made.

Shovel Test Data: None. 
Assessment/Recommendations: Over $75 \%$ of site appears intact; it lacks subsurface deposits. Site has low research potential and is judged to be not eligible for listing on NRHP. No further work recommended.

\section{GR549}

Location: Ca. $4.5 \mathrm{~km}$ SSE of intersection of U.S. Highway 84 and FM 2458 , and $1.3 \mathrm{~km}$ NW of confluence of Double Mountain Fork and Sand Creek.

Description: Open campsite on lower alluvial terrace of Double Mountain Fork; elevation $2210 \mathrm{ft} \mathrm{msl}$, area $2600 \mathrm{~m}^{2}$. Terrace has area of ca. 2-m-deep alluvial sands and an erosional remnant area covered with shallow colluvial deposits. Site is eroded, deflated, and dissected by several erosional gullies. Sparse scatter of lithic artifacts and bone fragment, with single burned rock feature. Most cultural materials found in erosional gullies. Some materials could have washed down from 41GR548, but burned rock feature is evidence of small campsite on terrace. No temporal components identified; undefined Prehistoric.

Features: Small ca. 30-cm-diameter cluster of ca. five burned sandstone fragments on edge of erosional gully cutting through alluvial deposit.

Cultural Materials Observed/Collected: Chopper of Potter chert, bone fragment, chert flake, and fragments of burned sandstone and Potter chert. One item collected (see Appendices $A$ and $B$ ).

Shovel Test Data: Two shovel tests excavated; one positive test found bison tooth at 60-80 cm. Both tests indicated soil depth of at least $100 \mathrm{~cm}$.

Assessment/Recommendations: Over $50 \%$ of site appears intact but lacks evidence of subsurface deposits. Site has low research potential and is judged to be not eligible for listing on NRHP. No further work recommended.

\section{$\underline{41 G R 551}$}

Location: Ca. $4.5 \mathrm{~km}$ ESE of intersection of U.S. Highway 84 and FM 2458, and $1.3 \mathrm{~km}$ NNW of confluence of Double Mountain Fork and Sand Creek.

Description: Lithic procurement area/open campsite on upland margin above Double Mountain Fork; elevation $2290 \mathrm{ft} \mathrm{msl,} \mathrm{area} 600 \mathrm{~m}^{2}$. Erosion has removed soil and exposed gravels in some areas of site. Scatter of 1ithic artifacts with five burned rock features. Slight disturbance from erosion, deflation, and dirt road which runs along upper edge of site. Site 41GR548 may have served as source of lithic raw materials for occupants of 41GR551, which is camping area with evidence of plant processing and limited use of chippable gravel exposures. No temporal components identified; undefined Prehistoric.

Features: Flve features; one cluster of burned sandstone slabs, two clusters of burned sandstone fragments with mano fragments, one cluster of burned sandstone fragments, and one cluster of burned Potter chert fragments. 
Cultural Materials Observed/Collected: Sandstone mano fragments; choppers of Potter chert and coarse-grained quartzite; gouge; debitage of Potter chert, coarse-grained quartzite, and possibly Edwards chert; and fragments of burned sandstone and Potter chert. No collections made.

Shovel Test Data: One negative shovel test indicated soil depth of at least $75 \mathrm{~cm}$.

Assessment/Recommendations: Over $50 \%$ of site appears intact; it contains features but may lack subsurface deposits. Site has good research potential and is judged to be potentially eligible for listing on NRHP. Recommend controlled collection, mapping, and testing.

\section{$\underline{41 G R 554}$}

Location: Ca. $4.2 \mathrm{~km}$ ESE of intersection of U.S. Highway 84 and FM 2458 , and $1.7 \mathrm{~km}$ NNW of confluence of Double Mountain Fork and Sand Creek.

Description: Lithic procurement area on bedrock terrace over lower alluvial terrace of Double Mountain Fork; elevation $2230 \mathrm{ft} \mathrm{msl}$, area $75 \mathrm{~m}^{2}$. Small scatter of tested cobbles and debitage. Site represents occasional testing and use of chippable gravels on terrace. No temporal components Identified; undefined Prehistoric.

\section{Features: None.}

Cultural Materials Observed/Collected: Tested cobbles and flakes of Potter chert, coarse-grained quartzite, and local chert. No collections made.

Shovel Test Data: None.

Assessment/Recommendations: Over $90 \%$ of site appears intact; it lacks subsurface deposits. Site has low research potential and is judged to be not eligible for listing on NRHP. No further work recommended.

\section{$\underline{41 G R 555}$}

Location: Ca. $3.3 \mathrm{~km}$ ESE of intersection of U.S. Highway 84 and FM 2458 , and $2.4 \mathrm{~km}$ NW of confluence of Double Mountain Fork and Sand Creek.

Description: Open campsite on erosional remnant of upland ridge overlooking floodplain of Double Mountain Fork; elevation $2240 \mathrm{ft} \mathrm{msl}$, area $6000 \mathrm{~m}^{2}$. Small gravels exposed on top of ridge; three flakes recovered from shovel test, with no cultural materials on surface. Open campsite; no gravels large enough to be useful for lithic reduction. No temporal components Identified; undefined Prehistoric.

Features: None.

Cultural Materials Observed/Collected: Debitage of Edwards and Potter chert. Three items collected (see Appendices A and B). 
Shovel Test Data: One shovel test yielded debitage to $20 \mathrm{~cm}$ and found soils at least $100 \mathrm{~cm}$ deep.

Assessment/Recommendations: Over 90\% of site appears intact; it contains subsurface deposits. Site has unknown research potential and is judged to be potentially eligible for listing on NRHP. Recommend mapping and testing.

\section{GR559}

Location: Ca. $5.2 \mathrm{~km}$ ESE of intersection of U.S. Highway 84 and FM 2458, and $0.6 \mathrm{~km}$ NNE of confluence of Double Mountain Fork and Sand Creek.

Description: Rockshelter on bluff overlooking drainage north of Sand Creek; elevation 2240-2250 ft msl, area $30 \mathrm{~m}^{2}$. Shelter formed by erosion of less-resistant sandstone from under darker conglomerate sandstone stratum, leaving overhang ca. 0.5-1.0 m high, $10 \mathrm{~m}$ long, and $3 \mathrm{~m}$ deep. Historic inscriptions on rock face above shelter. Shovel testing revealed burled cultural deposits in shelter, including charcoal fragments, burned bone fragments, and Potter chert flake. Temporal components are undefined Prehistoric and Historic (see Appendix G for description of historic component).

Features: None.

Cultural Materials Observed/Collected: Charcoal fragments, fragments of burned and unburned bones, Potter chert flake. Eleven samples and one item collected (see Appendices $A$ and $B)$.

Shovel Test Data: Two shovel tests in shelter yielded bone and charcoal fragments, one from $30-50 \mathrm{~cm}$ and other from $50-75 \mathrm{~cm}$. Soll depths ranged from $62-85 \mathrm{~cm}$.

Assessment/Recommendations: Over $90 \%$ of rockshelter appears intact; it contains subsurface deposits. Rockshelter has good research potential and is judged to be potentially eligible for listing on NRHP. Recommend mapping and testing.

\section{$\underline{41 G R 560}$}

Location: Ca. $3.6 \mathrm{~km}$ ESE of intersection of U.S. Highway 84 and FM 2458 , and $2.7 \mathrm{~km} \mathrm{E}$ of U.S. Highway 84 bridge over Double Mountain Fork.

Description: Lithic procurement area/open campsite on upland margin on small rise on canyon rim above Double Mountain Fork; elevation 2260-2300 ft msl, area 50,000 $\mathrm{m}^{2}$. Deflation left shallow eolian sands on higher parts of site and exposed bedrock along canyon rim; three small drainages formed ridges within site. Considerable scatter of ground and chipped stone tools, debitage, and fragments of burned rocks. Burned rock clusters found in higher, actively eroding areas. Undisturbed except for erosion and deflation. Camping area with plant processing and some lithic procurement. No temporal components identified; undefined Prehistoric. 
Features: Eight clusters of burned sandstone fragments, most ca. 75-100 cm in diameter, with one ca. $150 \mathrm{~cm}$ in diameter.

Cultural Materials Observed/Collected: Manos of sandstone and quartzite, choppers of Potter chert and coarse-grained quartzite, biface of Edwards chert, modified flakes of Edwards chert, debitage of Edwards chert, and burned fragments of Potter chert and sandstone. One item collected (see Appendices $A$ and B).

Shovel Test Data: One negative shovel test indicated soil depth of $\mathrm{ca} .40 \mathrm{~cm}$.

Assessment/Recommendations: Over $50 \%$ of site appears intact; it contains features but lacks subsurface deposits. Site has good research potential and is judged to be potentially eligible for listing on NRHP. Recommend controlled collection, mapping, and testing.

\section{GR562}

Location: Ca. $2.1 \mathrm{~km}$ ESE of intersection of U.S. Highway 84 and FM 2458 , and $1.4 \mathrm{~km}$ ENE of U.S. Highway 84 bridge over Double Mountain Fork.

Description: Open campsite on upper alluvial terrace above Double Mountain Fork; elevation $2240 \mathrm{ft} \mathrm{msl}$, area unknown. Deep deposit of alluvial and/or eolian sand with few low drainage areas. Single flake found on surface and flake, mussel. shell, and charcoal found in shovel test. Nature or function of site uncertain; possible camping area. No temporal components identified; undefined Prehistoric.

Features: None.

Cultural Materials Observed/Collected: Flake of Edwards chert, flake of local chert, mussel shell fragment, and few small flecks of charcoal. Three items collected (see Appendices A and B).

Shovel Test Data: One shovel test yielded cultural materials at ca. 29-30 cm and found soil depth of at least ca. $100 \mathrm{~cm}$.

Assessment/Recommendations: Over 90\% of site appears intact; it contains subsurface deposits. Site has good research potential and is judged to be potentially eligible for listing on NRHP. Recommend mapping and testing.

\section{GR563}

Location: Ca. $1.0 \mathrm{~km} \mathrm{SE}$ of intersection of U.S. Highway 84 and FM 2458 , and $0.7 \mathrm{~km}$ NNE of U.S. Highway 84 bridge over Double Mountain Fork.

Description: Lithic procurement area/open campsite on large low rise on upper alluvial terrace above Double Mountain Fork; elevation $2240 \mathrm{ft} \mathrm{msl}$, area $120,000 \mathrm{~m}^{2}$. Site found in plowed field; surface collected by Emmett Shedd but not recorded. Shedd noted 
Late Prehistoric artifact scatter. Current investigations found large, sparse scatter of debitage and some fragments of burned rocks on top and lower slope of rise. Site dispersed by plowing of field. Also, construction and use Justiceburg Cemetery has disturbed east part of site, which probably extended into cemetery at one time. Campsite; burned rock fragments may represent features disrupted by plow damage. Temporal component is Late Prehistoric.

Features: None.

Cultural Materials Observed/Collected: Debitage of Edwards chert, Potter chert, and coarse-grained quartzite; and burned fragments of Potter chert. No collections made.

Shovel Test Data: Two negative shovel tests found soils at least $100 \mathrm{~cm}$ deep.

Assessment/Recommendations: Less than $50 \%$ of site appears intact; it lacks subsurface deposits. Site has no research potential and is judged to be not eligible for listing on NRHP. No further work recommended.

\section{GR564}

Location: Ca. $0.7 \mathrm{~km} \mathrm{E}$ of intersection of U.S. Highway 84 and FM 2458 , and $1.0 \mathrm{~km} \mathrm{NNW}$ of U.S. Highway 84 bridge over Double Mountain Fork.

Description: Lithic procurement area/open campsite on large rise in upper alluvial terrace of Double Mountain Fork; elevation $2240 \mathrm{ft} \mathrm{msl}$, area $45,000 \mathrm{~m}^{2}$. Rise on north side of small tributary to Salt Branch covered with thin soil deposits and Quaternary gravels, caliche, and weathering bedrock fragments. Scatter of chipped stone tools, cores, tested cobbles, burned rocks, and two burned rock features. Most cultural materials and both features on top of rise in concentration of Potter chert cobbles. Light scatter of historic or recent trash is too sparse to constitute historic component. Undisturbed except for deflation. Lithic procurement main activity, but features indicate use as campsite. No temporal components identified; undefined Prehistoric.

Features: Two ca. 100-cm-diameter, widely separated clusters of burned Potter chert fragments.

Cultural Materials Observed/Collected: Chopper of Potter chert; scraper of local chert; cores, tested cobbles, and debitage of Potter chert and coarse-grained quartzite; and fragments of burned Potter chert. One item collected (see Appendices A and B).

Shovel Test Data: One shovel test yielded burned rock fragment at $0-20 \mathrm{~cm}$ and indicated soil depth of ca. $30 \mathrm{~cm}$.

Assessment/Recommendations: Over $75 \%$ of site appears intact; it contains features but may lack subsurface deposits. Site has no research potential and is judged to be not eligible for listing on NRHP. No further work recommended. 


\section{GR566}

Location: Ca. 4.4 km WNW of intersection of Garza/Kent county line and Double Mountain Fork, and $5.7 \mathrm{~km}$ NNE of confluence of Double Mountain Fork and Rocky Creek.

Description: Open campsite on large upland rise in pasture on unnamed drainage east of Cat Hollow; elevation 2360-2385 ft msl, area 105,000 $\mathrm{m}^{2}$. Artifact scatter with burned rock feature and $\mathrm{ca}$. 100 x75-m concentration of burned rock fragments and debitage on top of rise. Site could be dispersed by brush clearing; also disturbed by dirt road which runs across top of rise. Small campsite; more burned rock features probably were present before area was cleared. No temporal components identified; undefined Prehistoric.

Features: Ca. 150x100-cm cluster of burned sandstone fragments and vertical slab.

Cultural Materials Observed/Collected: Scraper of Edwards chert; debitage of local chert, red coarse-grained quartzite, and Edwards chert; and fragments of burned Potter chert, sandstone, and coarse-grained quartzite. One item collected (see Appendices A and B).

Shovel Test Data: One negative shovel test indicated soil depth of at least $75 \mathrm{~cm}$.

Assessment/Recommendations: Over $90 \%$ of site appears intact; it contains features but may lack subsurface deposits. Site has moderate research potential and is judged to be potentially eligible for listing on NRHP. Recommend mapping and testing.

\section{$\underline{41 G R 567}$}

Location: Ca. $2.2 \mathrm{~km}$ NNE of U.S. Highway 84 bridge over Sand Creek, and $4.1 \mathrm{~km}$ ESE of U.S. Highway 84 bridge over Double Mountain Fork.

Description: Rock art site in rockshelter eroded from bluff face overlooking Double Mountain Fork; elevation $2240 \mathrm{ft} \mathrm{msl}$, area $19.25 \mathrm{~m}^{2}$. Shelter is ca. $5.5 \mathrm{~m}$ wide and $3.5 \mathrm{~m}$ deep, with roof ca. $2 \mathrm{~m}$ high. Floor has shallow deposit of eolian sand and sand weathered from roof and walls of shelter, with no evidence of occupation. Two rock art panels: one historic inscription and one aboriginal petroglyph. Temporal components are undefined Prehistoric and Historic (see Appendix G for description of historic component).

Features: Aboriginal rock art panel (see Fig. 38a) ca. $11 \mathrm{~cm}$ wide and $11.5 \mathrm{~cm}$ tall is image of a hand carved into sandstone; four fingers clearly distinquishable, but thumb is eroded and barely discernible. Hand is smaller than adult; could be child's hand or representation of hand.

Cultural Materials Observed/Collected: None.

Shovel Test Data: One negative shovel test indicated soil depth of ca. $26 \mathrm{~cm}$.

Assessment/Recommendations: Over $90 \%$ of aboriginal rock art appears intact; it contains intact features but lacks subsurface deposits. Aboriginal rock art has excellent 
research potential and is judged to be potentially eligible for listing on NRHP. Recommend detailed recording (see Table 37 ).

\section{$\underline{41 G R 568}$}

Location: Ca. $1.1 \mathrm{~km}$ SSE of confluence of Double Mountain Fork and Grape Creek, and $2.1 \mathrm{~km}$ ENE of confluence of Double Mountain Fork and Little Grape Creek.

Description: Faunal locality on lower alluvial terrace above Grape Creek; elevation $2150 \mathrm{ft} \mathrm{msl}$, area $4 \mathrm{~m}^{2}$. Thirty-five deer bone fragments (some possibly burned) revealed in backhoe trench at depth of ca. $1.75 \mathrm{~m}$, extending $2 \mathrm{~m}$ along wall of trench. Bone fragments may be from single individual (see Appendix C) and were possibly articulated. No artifacts or features noted. Site may be bone midden or buried living surface. No temporal components 1dentified, but radiocarbon date suggests that site is Late Prehistoric.

Features: None.

Cultural Materials Observed/Collected: Deer bone fragments (some possibly burned), snail shells, charcoal fragments. Thirty-seven items collected (see Appendices A, B, and C).

Shovel Test Data: None; backhoe trench indicated soil depth of at least $2.5 \mathrm{~m}$.

Radiocarbon Date: Soll sample from $1.8 \mathrm{~m}$ below surface in Backhoe Trench 13 was dated to $1910 \pm 60$ B.P. $(\mathrm{Tx}-5764)$. Sample taken from level containing small burned bone fragments, charcoal, and numerous deer bones.

Assessment/Recommendations: Integrity of site unknown; it contains subsurface deposits. Site has good research potential and is judged to be potentially eligible for listing on NRHP. Recommend mapping and testing.

KENT COUNTY SITES

\section{$\underline{41 \mathrm{KT} 33}$}

Location: Ca. $1.1 \mathrm{~km} \mathrm{E}$ of intersection of Garza/Kent county line and Double Mountain Fork, and $0.7 \mathrm{~km}$ SSW of confluence of Double Mountain Fork and South Sage Creek.

Description: Open campsite on erosional remnant terrace overlooking alluvial terraces at confluence of Double Mountain Fork and South Sage Creek; elevation 2150-2170 ft msl, area $32,400 \mathrm{~m}^{2}$. Scatter of chipped and ground stone tools, debitage, burned rock fragments, and several burned rock features. Also, four ca. 5-m-diameter concentrations of burned rocks probably are eroded remains of features. Most of site on main part of terrace; small knoll separated from rest of terrace by low area contains small amount of debitage somewhat disturbed by brush clearing and two dirt roads; however, features appear to be intact except for slight erosion and deflation. Camping area of considerable size, 
with plant processing activities represented. No temporal components identified; undefined Prehistoric.

Features: Seven ca. 1-m-diameter clusters of sandstone; one also contains fragments of burned Potter chert.

Cultural Materials Observed/Collected: Two manos; two scrapers; debitage of Potter chert, local chert, and coarse-grained quartzite; and burned fragments of sandstone and Potter chert. Twenty-two items collected (see Appendices A and B).

Shovel Test Data: Two positive shovel tests; one with cultural materials from 20-40 $\mathrm{cm}$ and soils to $\mathrm{ca}$. $50 \mathrm{~cm}$, other with cultural materials from $0-60 \mathrm{~cm}$ and soils to at least $77 \mathrm{~cm}$.

Assessment/Recommendations: Over $50 \%$ of site appears intact; it contains features and subsurface deposits. Site has excellent research potential and is judged to be potentially eligible for listing on NRHP. Recommend controlled collection, mapping, and testing.

Location: Ca. $0.7 \mathrm{~km}$ ENE of intersection of Garza/Kent county line and Double Mountain Fork, and $0.9 \mathrm{~km}$ SW of confluence of Double Mountain Fork and South Sage Creek.

Description: Open campsite on erosional remnant knoll within lower alluvial terrace of Double Mountain Fork; elevation $2140 \mathrm{ft} \mathrm{msl}$, area $5850 \mathrm{~m}^{2}$. Knoll is covered with thick deposit of eolian and alluvial sands. Scatter of cores, debitage, burned rock fragments, and burned rock features. Site has been cleared, with disturbance from erosion and deflation. Small camping area. No temporal components identified; undefined Prehistoric.

Features: Seven clusters of burned sandstone; six measures ca. $100 \mathrm{~cm}$ in diameter, one measures $170 \times 90 \mathrm{~cm}$.

Cultural Materials Observed/Collected: Cores and flakes of Potter chert, Edwards chert, and local chert. Nineteen items collected (see Appendices A and B).

Shovel Test Data: Three positive shovel tests; two yielded cultural materials from 0-40 cm and found soils to ca. 50 and at least $80 \mathrm{~cm}$. Other yielded cultural materials from $0-60 \mathrm{~cm}$ and found soil depth of at least $80 \mathrm{~cm}$.

Assessment/Recommendations: Over 50\% of site appears intact; it contains features and subsurface deposits. Site has excellent research potential and is judged to be potentially eligible for listing on NRHP. Recommend controlled collection, mapping, and testing.

Location: Ca. $1.3 \mathrm{~km}$ ESE of intersection of Garza/Kent county line and Double Mountain Fork, and $1.1 \mathrm{~km}$ SSW of confluence of Double Mountain Fork and South Sage Creek. 
Description: Lithic procurement area on slope of erosional remnant above South Sage Creek; elevation $2180 \mathrm{ft} \mathrm{msl}$, area $8750 \mathrm{~m}^{2}$. Small outcrop of Quaternary gravels disturbed by erosion and plowing or brush clearing. Scatter of cores, tested cobbles, and few flakes corresponding with gravel outcrop. Small lithic procurement area. No temporal components identified; undefined Prehistoric.

Features: None.

Cultural Materials Observed/Collected: Cores, tested cobbles, and few flakes of Potter chert, local chert, and coarse-grained quartzite. No collections made.

Shovel Test Data: None.

Assessment/Recommendations: Less than 25\% of site appears intact; it lacks subsurface deposits. Site has low research potential and is judged to be not eligible for listing on NRHP. No further work recommended.

\section{$41 \mathrm{KT} 36$}

Location: Ca. $1.0 \mathrm{~km} \mathrm{SE}$ of intersection of Garza/Kent county line and Double Mountain Fork, and $1.3 \mathrm{~km}$ SSW of confluence of Double Mountain Fork and South Sage Creek.

Description: Open campsite on point on upland margin overlooking alluvial terraces at confluence of Double Mountain Fork and South Sage Creek; elevation 2245-2255 ft msl, area $19.6 \mathrm{~m}^{2}$. Small scatter of burned sandstone fragments (disturbed hearth) and single flake found within 5-m-diameter area. Remains of single camping episode. No temporal components identified; undefined Prehistoric.

Features: None.

Cultural Materials Observed/Collected: Flake of coarse-grained quartzite. No collections made.

Shovel Test Data: One negative shovel test indicated soil depth of ca. $60 \mathrm{~cm}$.

Assessment/Recommendations: Less than 50\% of site appears intact; it lacks subsurface deposits. Site has no research potential and is judged to be not eligible for listing on NRHP. No further work recommended.

\section{KT37}

Location: $\mathrm{Ca} .0 .8 \mathrm{~km}$ SE of intersection of Garza/Kent county line and Double Mountain Fork, and $1.5 \mathrm{~km}$ SW of confluence of Double Mountain Fork and South Sage Creek.

Description: Open campsite on point on upland margin overlooking alluvial terraces of Double Mountain Fork; elevation $2250 \mathrm{ft} \mathrm{msl,} \mathrm{area} 3000 \mathrm{~m}^{2}$. Scatter of chipped stone tools, debitage, burned rock fragments, and burned rock features. Brush clearing and erosion 
damaged two features. Small camping area. No temporal components identified; undefined Prehistoric.

Features: Four ca. 100-cm-diameter clusters of burned sandstone fragments; two intact and two destroyed.

Cultural Materials Observed/Collected: Gouge, Potter chert core, flake of Edwards chert, and fragments of burned sandstone. Three items collected (see Appendices A and B).

Shovel Test Data: Two positive shovel tests. One yielded flake at 20-40 cm and found soils to $\mathrm{ca} .80 \mathrm{~cm}$; other yielded burned rock fragment at 0-20 cm and found soils to ca. 40 $\mathrm{cm}$.

Assessment/Recommendations: Over $50 \%$ of site appears intact; it contains features and subsurface deposits. Site has good research potential and is judged to be potentially eligible for listing on NRHP. Recommend controlled collection, mapping, and testing.

\section{$\underline{41 \mathrm{KT} 38}$}

Location: Ca. $1.1 \mathrm{~km} \mathrm{E}$ of confluence of Double Mountain Fork and Grape Creek, and 1.6 $\mathrm{km}$ SSW of confluence of Double Mountain Fork and South Sage Creek.

Description: Open campsite on upland margin overlooking small side canyon at head of tributary to South Sage Creek; elevation $2270 \mathrm{ft} \mathrm{msl}$, area $875 \mathrm{~m}^{2}$. Sparse scatter of debitage and burned rocks; concentrations within overall scatter suggest that features were once present. Remains of campsite destroyed by brush clearing. No temporal components Identified; undefined Prehistoric.

Features: None.

Cultural Materials Observed/Collected: Flakes of Potter chert and red coarse-grained quartzite, and fragments of burned sandstone and Potter chert. Four items collected (see Appendices $A$ and B).

Shovel Test Data: Two positive shovel tests. One yielded burned rocks at $5 \mathrm{~cm}$; other ylelded two flakes at 0-20 cm. Soil depths were ca. 40 and $55 \mathrm{~cm}$.

Assessment/Recommendations: Over $75 \%$ of site appears intact; it contains subsurface deposits. Site has moderate research potential and is judged to be potentially eligible for listing on NRHP. Recommend mapping and testing.

$41 \mathrm{KT} 40$

Location: Ca. $0.4 \mathrm{~km}$ ESE of confluence of Double Mountain Fork and Grape Creek, and $2.1 \mathrm{~km}$ SW of confluence of Double Mountain Fork and South Sage Creek. 
Description: Open campsite on large erosional remnant terrace at end of upland point overlooking confluence of Grape Creek and Double Mountain Fork; elevation 2220-2240 ft ms], area $7500 \mathrm{~m}^{2}$. Scatter of cores, debitage, burned rock fragments, and burned rock feature; disturbed by pipeline, road, and blading and filling around drill hole. May have been small campsite but now virtually destroyed. No temporal components identified; undefined Prehistoric.

Features: Ca. l-m-diameter, badly disturbed cluster of burned sandstone fragments (near drill hole).

Cultural Materials Observed/Collected: Cores and flakes of Potter chert and coarsegrained quartzite, and fragments of burned sandstone. No collections made.

Shovel Test Data: One negative shovel test indicated that area is covered with ca. 70 $\mathrm{cm}$ of fine gravel (coarse sand).

Assessment/Recommendations: Less than $50 \%$ of site appears intact; it contains features but lacks subsurface deposits. Site has no research potential and is judged to be not eligible for listing on NRHP. No further work recommended.

\section{$41 \mathrm{KT} 41$}

Location: Ca. $0.6 \mathrm{~km}$ SE of confluence of Double Mountain Fork and Grape Creek, and $2.2 \mathrm{~km}$ SSW of confluence of Double Mountain Fork and South Sage Creek.

Description: Open campsite on three small terraces on upland margin overlooking Grape Creek at confluence with Double Mountain Fork; elevation 2240-2270 ft msl, area $6300 \mathrm{~m}^{2}$. Area deflated, with exposed bedrock and sandstone fragments. Lithic scatter with two burned rock features. Cultural materials have been shifted by erosion and deflation. Small camping area with plant processing. No temporal components identified; undefined Prehistoric.

Features: Two small ca. 1-m-diameter burned rock clusters, both badly disturbed.

Cultural Materials Observed/Collected: Chert biface; sandstone metate; hammerstone, cores, and flakes of Potter chert and coarse-grained quartzite; two flakes of Tecovas jasper; and burned sandstone fragments. No collections made.

Shovel Test Data: One negative shovel test indicated soil depth of ca. $35 \mathrm{~cm}$.

Assessment/Recommendations: Less than $50 \%$ of site appears intact; it contains features and exotics but lacks subsurface deposits. Site has no research potential and is judged to be not eligible for listing on NRHP. No further work recommended.

\section{$\underline{41 K T 42}$}

Location: Ca. $1.4 \mathrm{~km}$ SE of confluence of Double Mountain Fork and Grape Creek, and $1.1 \mathrm{~km} \mathrm{~S}$ of intersection of Garza/Kent county line and Double Mountain Fork. 
Description: Open campsite on upper alluvial terrace above Grape Creek; elevation 2140-2160 ft $\mathrm{ms} 1$, area $12,000 \mathrm{~m}^{2}$. Historic component with structural remains; prehistoric artifact scatter with some possible bedrock mortars in sandstone slab which was incorporated into historic structure. Area is deflated and eroded; prehistoric component has been severely damaged by erosion and by historic occupation. Surface collection likely. Prehistoric component is possible camping area, based on presence of bedrock mortars. Temporal components are late Archaic-Late Prehistoric and Historic (see Appendix G for description of historic component).

Features: None.

Cultural Materials observed/Collected: Ensor dart point and biface fragment of Edwards chert, Fresno arrow point of Alibates agate, and scraper and flakes of local chert. Four items collected (see Appendices $A$ and B).

Shovel Test Data: One negative shovel test indicated soil depth of ca. $65 \mathrm{~cm}$.

Assessment/Recommendations: Less than 25\% of prehistoric component appears intact; it lacks subsurface deposits but has exotics. Prehistoric component has no research potential and is judged to be not eligible for listing on NRHP. No further work recommended.

\section{$\underline{41 \mathrm{KT} 43}$}

Location: Ca. $1.0 \mathrm{~km}$ SE of confluence of Double Mountain Fork and Grape Creek, and $2.5 \mathrm{~km}$ SSW of confluence of Double Mountain Fork and South Sage Creek.

Description: Lithic procurement area on small point on upland margin overlooking alluvial terraces of Grape Creek at confluence with Double Mountain Fork; elevation 2240$2260 \mathrm{ft} \mathrm{msl}$, area $4500 \mathrm{~m}^{2}$. Deflation has exposed large number of Quaternary gravels, especially along edge of canyon rim. Scatter of tested cobbles, cores, hammerstones, and debitage following natural gravel outcrop. No evidence of lithic reduction, so site is solely lithic procurement area. No temporal components identified; undefined Prehistoric.

Features: None.

Cultural Materials Observed/Collected: Cores, tested cobbles, and flakes of Potter chert, local chert, and coarse-grained quartzite; and hammerstones of coarse-grained quartzite. No collections made.

Shovel Test Data: One negative shovel test indicated soil depth of ca. $35 \mathrm{~cm}$.

Assessment/Recommendations: Over $75 \%$ of site appears intact; it lacks subsurface deposits. Site has good research potential and is judged to be potentially eligible for listing on NRHP. Recommend controlled collection and mapping.

$41 \mathrm{KT} 44$

Location: Ca. $1.2 \mathrm{~km}$ SSE of confluence of Double Mountain Fork and Grape Creek, and $2.8 \mathrm{~km}$ SSW of confluence of Double Mountain Fork and South Sage Creek. 
Description: Faunal locality in erosional gully cutting through upper and lower alluvial terraces above Grape Creek; elevation $2180 \mathrm{ft} \mathrm{msl}$, area $78.5 \mathrm{~m}^{2}$. Disarticulated bison bones found at depth of $65 \mathrm{~cm}$ in cutbank of 3-m-deep gully near valley wall. Sediments are alluvial deposits with very small amount of gravels. No cultural materials recovered from area troweled around bones. No conclusive evidence that bones represent prehistoric bison kill, but it is possible. No temporal components identified; undefined Prehistoric.

Features: None.

Cultural Materials Observed/Collected: Bison bone fragments include femur, tibia, and numerous small unidentified fragments. No collections made.

Shovel Test Data: None.

Assessment/Recommendations: Integrity of site is unknown; it contains subsurface deposits. Site has good research potential and is judged to be potentially eligible for listing on NRHP. Recommend mapping and testing.

$\underline{41 \mathrm{KT} 45}$

Location: Ca. $3.0 \mathrm{~km} \mathrm{~S}$ of confluence of Double Mountain Fork and South Sage Creek, and $3.5 \mathrm{~km}$ E of confluence of Double Mountain Fork and Little Grape Creek.

Description: Lithic procurement area along edge of canyon rim on upland margin above Sage Creek; elevation of $2250 \mathrm{ft} \mathrm{msl}$, area $16,000 \mathrm{~m}^{2}$. Area is deflated and eroded, with considerable exposure of Quaternary gravels. Sparse scatter of cores, tested cobbles, and flakes. Site appears to be lithic procurement area utilizing gravel outcrop. No temporal components identified; undefined Prehistoric.

Features: None.

Cultural Materials Observed/Collected: Cores, tested cobbles, and few flakes of Potter chert, coarse-grained quartzite, and local chert. No collections made.

Shovel Test Data: None.

Assessment/Recommendations: Over $90 \%$ of site appears intact; it lacks subsurface deposits. Site has good research potential and is judged to be potentially eligible for listing on NRHP. Recommend controlled collection and mapping.

41KT47

Location: Ca. $3.1 \mathrm{~km}$ SSW of confluence of Double Mountain Fork and South Sage Creek, and $1.8 \mathrm{~km}$ SE of confluence of Double Mountain Fork and Grape Creek. 
Description: Open campsite on lower slope of upland rise near canyon rim above Grape Creek; elevation 2270-2280 ft $\mathrm{msl}$, area $5850 \mathrm{~m}^{2}$. Site is in deep eolian deposit in cleared field and is slightly eroded, especially near rim. Sparse artifact scatter with sandstone slabs which may represent destroyed feature. Site is probably camping area. Temporal component is Late Prehistoric, possibly Garza Complex.

Features: None.

Cultural Materials Observed/Collected: Pecos Glaze Polychrome V rim sherd; Edwards chert scraper; and flakes of Edwards chert, Potter chert, local chert, and coarse-grained quartzite. Four items collected (see Appendices A and B).

Shovel Test Data: Two shovel tests excavated; one positive. Negative test indicated soil depth of at least $100 \mathrm{~cm}$; positive test yielded cultural materials at 20-60 cm and indicated soil depth of at least $80 \mathrm{~cm}$.

Assessment/Recommendations: Over 50\% of site appears intact; it contains subsurface deposits and exotics. Site has good research potential and is judged to be potentlally eligible for listing on NRHP. Recommend mapping and testing.

\section{$\underline{41 K T 49}$}

Location: Ca. $3.4 \mathrm{~km}$ SSW of confluence of Double Mountain Fork and South Sage Creek, and $3.1 \mathrm{~km}$ ESE of confluence of Double Mountain Fork and Little Grape Creek.

Description: Lithic procurement area/open campsite on canyon $\mathrm{rim}$ in upland margin above Grape Creek; elevation 2230-2280 ft msl, area $6000 \mathrm{~m}^{2}$. Site is on slope of small rise and continues down bluff slope. Although it is dissected by two small erosional drainages, site has considerable deposit of eolian sand. Artifact scatter with numerous small concentrations of burned rocks (probably eroded features) eroding out of sand in upper area of site. Cultural materials most evident in eroded areas around drainages. Campsite of considerable size, with lithic procurement and plant processing. Temporal component is Archaic.

Features: Numerous ca. 50-75-cm-diameter concentrations of burned sandstone frag ments.

Cultural Materials Observed/Collected: Untyped dart point of Edwards chert, bifaces, unifaces, scraper, mano, debitage, and fragments of burned sandstone. Chipped stone tools and debitage are primarily of local chert and Potter chert. Six items collected (see Appendices $\mathrm{A}$ and $\mathrm{B}$ ).

Shovel Test Data: One shovel test yielded cultural materials at $0-20 \mathrm{~cm}$ and indicated soil depth of ca. $95 \mathrm{~cm}$.

Assessment/Recommendations: Over 75\% of site appears intact; it contains features and subsurface deposits. Site has excellent research potential and is judged to be potentially eligible for listing on NRHP. Recommend mapping and testing. 


\section{$\underline{41 K T 50}$}

Location: Ca. $3.5 \mathrm{~km}$ SSW of confluence of Double Mountain Fork and South Sage Creek, and $3.1 \mathrm{~km}$ ESE of confluence of Double Mountain Fork and Little Grape Creek.

Description: Rock art site in bluff overhang overlooking Grape Creek valley; elevation $2260 \mathrm{ft} \mathrm{msl}$, area $47.5 \mathrm{~m}^{2}$. Shelter is ca. $3 \mathrm{~m} \mathrm{high,} 9.5 \mathrm{~m}$ long, and $5 \mathrm{~m}$ wide, and formed by spalling of large blocks of sandstone, followed by erosion of softer underlying sandstone stratum. Flat 5-m-wide area below shelter is covered with thin deposit of eolian and weathered sand which has no cultural deposits. Four panels of rock art (three aboriginal; see Flg. 34c-e) on back of shelter and on face of overhang. Temporal components are undefined Prehistoric and Historic (see Appendix G for description of historic component).

Features: Three panels of aboriginal petroglyphs; first is ca. $25 \mathrm{~cm}$ long and $14 \mathrm{~cm}$ tall. Contains two small circular depressions (dots) $1 \mathrm{~cm}$ in diameter and three short, wide gouge marks $3 \mathrm{~cm}$ long and $1 \mathrm{~cm}$ wide. Dots are side by side, with two gouge marks below and to side and third mark above and to one side. Second panel, $14 \mathrm{~cm}$ tall and 7.5 cm wide, has two parallel vertical tally marks. Mark on left is $3 \mathrm{~cm}$ long and $0.5 \mathrm{~cm}$ wide; mark on right is $14 \mathrm{~cm}$ long and $2.5 \mathrm{~cm}$ wide. Third panel is largest $(75 \mathrm{~cm}$ long and $15 \mathrm{~cm}$ tall) and most complicated. A number of tally marks, both parallel and perpendicular, and two geometric elements are separated into three groups; two groups are roughly $15 \times 15 \mathrm{~cm}$, other is ca. $5 \mathrm{~cm}$ wide and $7.5 \mathrm{~cm}$ tall.

\section{Cultural Materials Observed/Collected: None.}

Shovel Test Data: One negative shovel test in bench area below rock art found soil depth of ca. $70 \mathrm{~cm}$.

Assessment/Recommendations: Over $90 \%$ of aboriginal rock art appears intact; it lacks associated subsurface deposits. Aboriginal rock art has excellent research potential and is judged to be potentially eligible for listing on NRHP. Recommend detailed recording (see Table 37).

\section{$\underline{41 K T 51}$}

Location: Ca. $3.5 \mathrm{~km}$ SSW of confluence of Double Mountain Fork and South Sage Creek, and $2.9 \mathrm{~km}$ ESE of confluence of Double Mountain Fork and Little Grape Creek.

Description: Open campsite on levee deposit on lower alluvial terrace of Grape Creek; elevation $2170 \mathrm{ft} \mathrm{msl,} \mathrm{area} 12,760 \mathrm{~m}^{2}$. Sparse artifact scatter exposed in dirt road. Disturbed slightly by construction of artificial levee extending from one end of natural levee and by dirt road which runs along top of natural levee. Considered to be campsite due to presence of possibly burned sandstone fragments. No temporal components identified; undefined Prehistoric.

Features: None. 
Cultural Materials Observed/Collected: Secondary and tertiary flakes of local and Edwards chert, core of local chert, and possibly burned fragments of sandstone. Five items collected (see Appendices A and B).

Shovel Test Data: One shovel test yielded cultural materials from $0-40 \mathrm{~cm}$, snall shell at 60-80 cm, and indicated soil depth of at least $80 \mathrm{~cm}$.

Assessment/Recommendations: Over $90 \%$ of site appears intact; it contains subsurface deposits. Site has good research potential and is judged to be potentially eligible for listing on NRHP. Recommend mapping and testing.

\section{$\underline{41 K T 52}$}

Location: Ca. 2.0 km SSE of confluence of Double Mountain Fork and Grape Creek, and $2.6 \mathrm{~km}$ ESE of confluence of Double Mountain Fork and Little Grape Creek.

Description: Open campsite on upper alluvial terrace within small bend in Grape Creek; elevation $2170 \mathrm{ft} \mathrm{msl}$, area $2400 \mathrm{~m}^{2}$. Upper terrace is separated from lower terrace by overflow cutoff chute. Artifact scatter with burned rock features. Features and most cultural materials found in cutbank of Grape Creek; shovel testing in terrace found buried cultural deposits. Site may contain at least two components separated by $\mathrm{ca} .50 \mathrm{~cm}$ of alluvial deposits. Upper component contains small number of mussel shell fragments and chipped stone artifacts, while lower component contains burned rocks, hearths, and small amount of chipped stone. Some disturbance from erosion and sloughing of cutbank. Campsite of considerable size, with plant processing and procurement of riverine resources. No temporal components identified; undefined Prehistoric (multicomponent).

Features: Four definite features exposed in cutbank. One slab basin hearth is $60 \mathrm{~cm}$ long, $15 \mathrm{~cm}$ thick, and ca. $105 \mathrm{~cm}$ below surface. Second slab basin is ca. $35 \mathrm{~cm}$ long, 15 $\mathrm{cm}$ thick, and ca. $170 \mathrm{~cm}$ below surface. Other two features are slabs found at 105 and 95 $\mathrm{cm}$ below surface; deeper is $25 \mathrm{~cm}$ long, while other is $35 \mathrm{~cm}$ long. Latter features are 70 $\mathrm{cm}$ apart and may be single large hearth.

Cultural Materials Observed/Collected: Three sandstone grinding slabs, debitage, burned sandstone fragments, and mussel shell fragments. Twelve items collected (see Appendices A and B).

Shovel Test Data: Three of four shovel tests on alluvial terrace were positive. One yielded cultural materials at 20-60 cm, another at 0-20 and 80-120 cm, and third at 60-80 $\mathrm{cm}$ below surface. Negative test indicated soil depth of at least $75 \mathrm{~cm}$, while positive tests found soils at least $120 \mathrm{~cm}$ deep.

Assessment/Recommendations: Over 90\% of site appears intact; it contains features and subsurface deposits. Site has excellent research potential and is judged to be potentially eligible for listing on NRHP. Recommend mapping and testing. 
Location: Ca. $2.3 \mathrm{~km}$ SSE of confluence of Double Mountain Fork and Grape Creek, and $2.6 \mathrm{~km}$ ESE of confluence of Double Mountain Fork and Little Grape Creek.

Description: Open campsite on lower alluvial terrace slope above Grape Creek; elevation 2160-2180 ft msl, area $20,400 \mathrm{~m}^{2}$. Deep deposit of alluvial sands dissected by small erosional drainages along lower edge of terrace. Sparse artifact scatter on surface of site in rodent mounds, with burned rock feature deep in cutbank of erosional gully. Possibility that site contains stratified cultural deposits. Surface disturbance from plowing or brush clearing. Small camping area. Temporal component is Late Prehistoric (possibly Garza Complex), with possible older component below it.

Features: Slab-lined hearth $\mathrm{ca} .55 \mathrm{~cm}$ long and $\mathrm{ca} .100 \mathrm{~cm}$ below ground surface in cutbank.

Cultural Materials Observed/Collected: Twenty-seven sherds of Pecos Glaze Polychrome V (probably from same vessel), three sherds of Pecos Faint Striated, untyped sherd, and end scraper and flake of Edwards chert. Thirty-two items collected (see Appendices A and B).

Shovel Test Data: Two shovel tests excavated, one positive. Positive test yielded ceramics at 0-60 cm and indicated soil depth of at least $80 \mathrm{~cm}$. Negative test indicated soil depth of $\mathrm{ca} .40 \mathrm{~cm}$.

Assessment/Recommendations: Over $90 \%$ of site appears intact; it contains features, exotics, and subsurface deposits. Site has excellent research potential and is judged to be potentially eligible for listing on NRHP. Recommend mapping and testing.

\section{KT55}

Location: Ca. $2.5 \mathrm{~km}$ SSE of confluence of Double Mountain Fork and Grape Creek, and $2.7 \mathrm{~km}$ ESE of confluence of Double Mountain Fork and Little Grape Creek.

Description: Rock art site in rockshelter eroded from sandstone caprock face of bluff overlooking Grape Creek; elevation $2245 \mathrm{ft} \mathrm{msl,} \mathrm{area} 13 \mathrm{~m}^{2}$. Shelter is ca. $6.5 \mathrm{~m} \mathrm{long}$ and $2 \mathrm{~m}$ deep; mouth is closed by wall of sandstone eroded through in several places, providing access to shelter. Four panels of aboriginal rock art on interior near openings. Floor covered with thin deposit of blow sand and sandstone fragments spalled from inside of shelter, with no evidence of cultural deposits. No temporal components 1dentified; undefined Prehistoric.

Features: Four panels of petroglyphs (see Fig. 38b-e). First ca. $9 \mathrm{~cm}$ wide and 6.5 $\mathrm{cm}$ tall has two diagonal cruciform figures, one $5 \mathrm{~cm}$ across and other $5 \mathrm{~cm}$ long and $4 \mathrm{~cm}$ tall. Second panel, ca. $15 \mathrm{~cm}$ long and $12.5 \mathrm{~cm}$ tall, has single possible anthropomorphic figure of irregularly shaped enclosures connected by curved lines, with two lines extending from bottom. Third panel, ca. $12 \mathrm{~cm}$ long and $11 \mathrm{~cm}$ tall, has single cruciform flgure tilted to left. Figure is made up of "vertical" line $12 \mathrm{~cm}$ long, "horizontal" 1 ine $11 \mathrm{~cm}$ long, and 6-cm-long vertical line extending downward at right end of horizontal line. 
Fourth panel, $17.5 \mathrm{~cm}$ long and $17 \mathrm{~cm}$ tall, has vertical tally marks arranged in series that curves upward to right, so that tally marks are diagonal. Vertical tally mark on left end of series is bifurcated at top, forming "Y." Tally marks range from 4-8.5 cm long, with average length of $5.5 \mathrm{~cm}$.

Cultural Materials Observed/Collected: None.

Shovel Test Data: None.

Assessment/Recommendations: Over $75 \%$ of site appears intact; it contains features but lacks associated subsurface deposits. Site has excellent research potential and is judged to be potentially eligible for listing on NRHP. Recommend detailed recording (see Table 37).

$\underline{41 K T 56}$

Location: Ca. $3.0 \mathrm{~km}$ SSE of confluence of Double Mountain Fork and Grape Creek, and $7.0 \mathrm{~km} \mathrm{E}$ of confluence of Double Mountain Fork and Gobbler Creek.

Description: Open campsite exposed in dirt road on lower alluvial terrace above Grape Creek; elevation $2170 \mathrm{ft} \mathrm{msl}$, area $25 \mathrm{~m}^{2}$. Terrace is narrow, with bluff slope only $50 \mathrm{~m}$ from creek. Single burned rock feature slightly scattered along road. No other cultural materials on surface or in screened feature fill. Could be small, single-event campsite. No temporal components identified; undefined Prehistoric.

Features: Cluster $75 \mathrm{~cm}$ in diameter of burned sandstone fragments; slightly disturbed by vehicular and cattle traffic.

Cultural Materials Observed/Collected: None.

Shovel Test Data: One negative shovel test indicated soil depth of $\mathrm{ca} .70 \mathrm{~cm}$.

Assessment/Recommendations: Less than $10 \%$ of site appears intact; it contains a feature but lacks subsurface deposits. Site has no research potential and is judged to be not eligible for listing on NRHP. No further work recommended.

\section{KT57}

Location: Ca. $3.0 \mathrm{~km}$ SSE of confluence of Double Mountain Fork and Grape Creek, and $6.5 \mathrm{~km}$ ESE of confluence of Double Mountain Fork and Little Grape Creek.

Description: Rockshelter/rock art site in overhang shelter on bluff slope overlooking Grape Creek; elevation $2250 \mathrm{ft} \mathrm{msl}$, area $30 \mathrm{~m}^{2}$. Erosion and sloughing have created small protected space beneath more-resistant sandstone; shelter is ca. $9 \mathrm{~m}$ long and $2 \mathrm{~m}$ deep, with 1.5-m-high roof. Floor covered with deposit of eolian sand and weathered sand from roof and walls, which has cultural deposits. Three panels of rock art (see Fig. 34f-h) cover area ca. $2.6 \mathrm{~m}$ long and $50 \mathrm{~cm}$ tall on back wall of shelter. Occupied rockshelter. No temporal components Identified; undefined Prehistoric. 
Features: Three petroglyph panels. First, $80 \mathrm{~cm}$ long and $30 \mathrm{~cm}$ tall, contains several geometric elements, including three vertical tally marks ca. $9 \mathrm{~cm}$ long and $3 \mathrm{~cm}$ apart, rectangular element $10 \mathrm{~cm}$ wide and $13 \mathrm{~cm}$ tall with horizontal lines fllling bottom half of rectangle, another rectangle $5 \mathrm{~cm}$ wide and $30 \mathrm{~cm}$ tall with vertical line through center of upper half and horizontal lines filling entire element, roughly oval element $20 \mathrm{~cm}$ tall and $11 \mathrm{~cm}$ wide formed of irregular triangles with rectangular element drawn onto right side, and vertical cruclform $20 \mathrm{~cm}$ tall bisected by horizontal line $19 \mathrm{~cm}$ long. Second panel, 20 $\mathrm{cm}$ tall and $21 \mathrm{~cm}$ wide, has four parallel diagonal lines 17-20 cm long and $4 \mathrm{~cm}$ apart. Third panel is below first two on upper edge of small shelf. Ca. 10-cm-long and 2.5-cmtall serles of 11 short tally marks truncated where part of shelf broke off.

Cultural Materials Observed/Collected: Local chert flake, flake of coarse-grained quartzite, mussel shell fragments, and charcoal fragments. Thirteen items collected (see Appendices $\mathrm{A}$ and $\mathrm{B}$ ).

Shovel Test Data: One positive shovel test in shelter yielded cultural materials from 20-45 cm and indicated soil depth of $46 \mathrm{~cm}$.

Assessment/Recommendations: Over 75\% of rock art and subsurface component appear intact. Rockshelter deposit has good research potential and is judged to be potentially eligible for listing on NRHP, while rock art has excellent research potential and is judged to be potentially eligible for listing on NRHP. Recommend mapping and testing of cultural deposit and detailed recording of rock art (see Table 37 ).

\section{$41 \mathrm{KT} 61$}

Location: $\mathrm{Ca} .3 .3 \mathrm{~km}$ SSE of confluence of Double Mountain Fork and Grape Creek, and $6.2 \mathrm{~km}$ ESE of confluence of Double Mountain Fork and Cat Hollow.

Description: Lithic procurement area/open campsite on upper alluvial/colluvial terrace above Grape Creek; elevation 2180-2220 ft msl, area 22,500 $\mathrm{m}^{2}$. Area is deflated with gravels exposed on surface; drainage cuts into edge of site. Artifact scatter with burned rocks (possible features) buried $1 \mathrm{~m}$ deep in gully wall at east end of site. Slightly disturbed by dirt road which cuts through center of site. Possible camping area, with evidence of plant processing and limited lithic procurement. No temporal components identified; undefined Prehistoric.

Features: Hearths may be represented by burned rocks buried $1 \mathrm{~m}$ deep in terrace.

Cultural Materials Observed/Collected: Quartzite mano; two quartzite choppers; and cores, tested cobbles, and flakes of Potter chert, coarse-grained quartzite, and local chert. Two items collected (see Appendices A and B).

Shovel Test Data: One negative shovel test indicated soil depth of ca. $60 \mathrm{~cm}$.

Assessment/Recommendations: Over $90 \%$ of site appears intact; it may contain features and subsurface deposits. Site has unknown research potential and is judged to be potentlally eligible for listing on NRHP. Recommend controlled collection, mapping, and testing. 
Location: Ca. $3.5 \mathrm{~km}$ SSE of confluence of Double Mountain Fork and Grape Creek, and $6.6 \mathrm{~km}$ ESE of confluence of Double Mountain Fork and Cat Hollow.

Description: Lithic scatter on eroded knoll at end of upland point overlooking Grape Creek and a spring; elevation 2280-2300 ft msl, area $2400 \mathrm{~m}^{2}$. Area is deflated, and small gravels are exposed on surface. Sparse artifact scatter. Only activity evident is initial reduction of cobbles. No temporal components identified; undefined Prehistoric.

Features: None.

Cultural Materials Observed/Collected: Flake of Potter chert with bifacial retouch and flakes of coarse-grained quartzite. No collections made.

Shovel Test Data: One negative shovel test indicated soil depth of ca. $40 \mathrm{~cm}$.

Assessment/Recommendations: Over $90 \%$ of site appears 1ntact; it lacks subsurface deposits. Site has low research potential and is judged to be not eligible for listing on NRHP. No further work recommended.

\section{$41 \mathrm{KT} 63$}

Location: Ca. $3.7 \mathrm{~km}$ SSE of confluence of Double Mountain Fork and Grape Creek, and $6.8 \mathrm{~km}$ ESE of confluence of Double Mountain Fork and Cat Hollow.

Description: Lithic scatter at end of eroding upland ridge overlooking confluence of two small upland springs near Grape Creek; elevation 2290-2300 ft insl, area $3000 \mathrm{~m}^{2}$. Ridge is long, narrow knoll with great deal of small gravels exposed on deflated surface. Sparse scatter of debitage. Activities indicated are initial cobble reduction and some limited tool manufacture. No temporal components identified; undefined Prehistoric.

Features: None.

Cultural Materials Observed/Collected: Primary and secondary flakes of local and Edwards chert, with tertiary flake and bifacial thinning flake. No collections made.

Shovel Test Data: One negative shovel test indicated soll depth of $\mathrm{ca} .16 \mathrm{~cm}$.

Assessment/Recommendations: Over $90 \%$ of site appears intact; it lacks subsurface deposits. Site has low research potential and is judged to be not eligible for listing on NRHP. No further work recommended.

\section{$\underline{41 K T 65}$}

Location: Ca. $4.1 \mathrm{~km}$ SSE of confluence of Double Mountain Fork and Grape Creek, and $6.9 \mathrm{~km}$ ESE of confluence of Double Mountain Fork and Rocky Creek. 
Description: Rock art site in rockshelter below canyon rim of Grape Creek; elevation $2270 \mathrm{ft} \mathrm{msl}$, area $55 \mathrm{~m}^{2}$. Small shelter has eroded out of stratum of soft sandstone below stratum of more-resistant ferruginous sandstone; it is ca. $11 \mathrm{~m}$ long and $3.5 \mathrm{~m}$ deep, with small bench area on slope in front. Shelter divided by wall of sandstone, with eroded passageway connecting two halves; one room partially walled by sandstone slab with two large holes resembling windows. Walls bear one panel of historic rock art and three panels of aborlginal rock art. Floor of shelter is bare sandstone; bench area in front of shelter has no cultural deposits. Temporal components are undefined Prehistoric and Historic (see Appendix G for description of historic component).

Features: Three panels of aboriginal petroglyphs (see Fig. 39a-c). First, ca. $95 \mathrm{~cm}$ long and $45 \mathrm{~cm}$ tall, contains series of vertical and slightly diagonal tally marks. Fifteen vertical tally marks have average length of $40 \mathrm{~cm}$, ranging from $25-50 \mathrm{~cm}$. Seven diagonal tally marks are separated from vertical ones by crack in rock; average $25 \mathrm{~cm}$ long, ranging from $7-35 \mathrm{~cm}$.

Second panel, $85 \mathrm{~cm}$ long and $45 \mathrm{~cm}$ tall, contains three groups of glyphs. One is 40-cm-long and 20-cm-tall series of 11 vertical tally marks. Another is ca. 37-cm-long and 24-cm-tall group of faint intersecting lines. Third group, $23 \mathrm{~cm}$ tall and $25 \mathrm{~cm} l o n g$, consists of upward-pointing arrow within long arc; right side of arc is zigzag line. Surrounding arrow figure are five tally marks from 6 to $15 \mathrm{~cm}$ long, all but one nearvertical.

Third panel is largest (90 cm tall and ca. $50 \mathrm{~cm}$ wide) and most complicated. Glyphs augmented by deep gouges cut into sandstone by shrubs rubbing against rock. Figure at top of panel wraps around into "window"; it is 10-cm-tall, 5-cm-wide rectangle with two perpendicular lines drawn through center and two small round holes below it. Near bottom of panel are three human figures; bodies represented by rectangles with inverted $V^{\prime} s$ forming bottoms of rectangles and legs. Arms are bent at elbows, and heads are triangular, forming W. One figure has vertical line drawn through center of body and horizontal lines at shoulders and just above legs. Long curved line drawn from top of head down to right side. Panel also contains few faint tally marks, most ca. $10 \mathrm{~cm}$ long.

Cultural Materials Observed/Collected: None.

Shovel Test Data: One negative shovel test on bench outside shelter indicated soil depth of ca. $50 \mathrm{~cm}$.

Assessment/Recommendations: Over $90 \%$ of aboriginal rock art appears intact; it lacks associated subsurface deposits. Aboriginal rock art has excellent research potential and is judged to be potentially eligible for listing on NRHP. Recommend detalled recording (see Table 37).

\section{$41 \mathrm{KT} 66$}

Location: Ca. $4.1 \mathrm{~km}$ SSE of confluence of Double Mountain Fork and Grape Creek, and $6.7 \mathrm{~km}$ ESE of confluence of Double Mountain Fork and Rocky Creek. 
Description: Open campsite on lower alluvial terrace above Grape Creek; elevation $2210 \mathrm{ft} \mathrm{msl}$, area $3360 \mathrm{~m}^{2}$. Terrace slightly eroded at lower edges but has deep deposit of alluvial sands. Artifact scatter with burned rock features. One feature is on upper part of terrace, while other features and scatter are in or near erosional areas at terrace edge. Campsite of some size, with evidence of plant processing. No temporal components identified; undefined Prehistoric.

Features: Five burned rock features. First is disturbed cluster of burned rocks in cutbank of small gully. Second cluster of burned rocks found on surface near terrace edge is ca. $60 \mathrm{~cm}$ in diameter and assoclated with burned rock scatter $300 \mathrm{~cm}$ in diameter. Third is $80 \times 50-\mathrm{cm}$ cluster of burned rocks found on surface. Fourth is ca. 12x5-m concentration of burned rocks and burned chert cobble on slight slope on upper edge of terrace, representing several features merged through deflation and erosion. Fifth feature is disturbed cluster of burned rocks eroding out of terrace edge.

Cultural Materials Observed/Collected: Sandstone mano fragment, burned chert cobble, and few flakes of chert and quartzite. Two items collected (see Appendices $A$ and B).

Shovel Test Data: Two shovel tests excavated, one positive. Positive test yielded cultural materials from $0-20 \mathrm{~cm}$ and indicated soil depth of at least $90 \mathrm{~cm}$. Negative test indicated soil depth of at least $80 \mathrm{~cm}$.

Assessment/Recommendations: Over $75 \%$ of site appears intact; it contains features and subsurface deposits. Site has good research potentlal and is judged to be potentially eligible for listing on NRHP. Recommend mapping and testing.

\section{$41 \mathrm{KT} 67$}

Location: Ca. $4.3 \mathrm{~km}$ SSE of confluence of Double Mountain Fork and Grape Creek, and $6.9 \mathrm{~km}$ ESE of confluence of Double Mountain Fork and Gobbler Creek.

Description: Lithic procurement area on canyon rim of upland margin overlooking Grape Creek; elevation $2280 \mathrm{ft} \mathrm{msl}$, area $1500 \mathrm{~m}^{2}$. Lower edge of area eroded almost to bedrock with few Quaternary gravels visible on surface; upper edge retains eolian deposits. Sparse scatter of broken cobbles and debitage concentrated on bedrock exposure, with small amount in eolian deposits. Site may extend into upland areas burled beneath eolian sands; however, no surface indication of this. Small lithic procurement or tool manufacturing area. No temporal components Identified; undefined Prehistoric.

Features: None.

Cultural Materials Observed/Collected: Secondary and tertiary flakes of mediumgrained quartzite and Potter chert, tertiary flakes of Edwards chert, and broken cobble fragments of Potter chert and medium-grained quartzite. No collections made.

Shovel Test Data: One negative shovel test in eollan deposits indicated soil depth of ca. $55 \mathrm{~cm}$. 
Assessment/Recommendations: Over $50 \%$ of site appears intact; it may lack subsurface deposits. Site has low research potential and is judged to be not eligible for listing on NRHP. No further work recommended.

\section{$\underline{41 \mathrm{KT} 68}$}

Location: Ca. $4.6 \mathrm{~km}$ SSE of confluence of Double Mountain Fork and Grape Creek, and $6.9 \mathrm{~km}$ ESE of confluence of Double Mountain Fork and Rocky Creek.

Description: Rock art site in rockshelter eroded out of bluff slope overlooking Grape Creek; elevation $2245 \mathrm{ft} \mathrm{msl}$, area $3 \mathrm{~m}^{2}$. Shelter formed by erosion of softer stratum of sandstone from under stratum of more-resistant ferruginous sandstone. Shelter is $4 \mathrm{~m}$ wide and $3 \mathrm{~m}$ deep, with ceiling ca. $2 \mathrm{~m}$ high; floor is bare rock. Probable aboriginal petroglyphs on floor of shelter are obscured by recent graffiti; difficult to determine which markings are aboriginal. No temporal components identified; undefined Prehistoric.

Features: Probable aboriginal petroglyphs (see Fig. 39d) cover area ca. $3 \mathrm{~m}$ wide and $0.8 \mathrm{~m}$ tall. Most are tally marks, although some are geometric elements and one is possible anthropomorphic figure. One of the two series of tally marks is $35 \mathrm{~cm}$ long and contains 23 marks, each ca. $5 \mathrm{~cm}$ long. Other series is ca. $42 \mathrm{~cm}$ long and contains 31 marks, each ca. 3-5 cm long. Horizontal line drawn through first 17 marks on left side of second series. Anthropomorphic figure is $25 \mathrm{~cm}$ wide and $15 \mathrm{~cm}$ tall, has rectangular body $4 \mathrm{~cm}$ wide and 7 $\mathrm{cm}$ tall, circular head, and ca. 15-cm-long arms depicted by diagonal lines that point down and to right. Third ca. 10-cm-long line points down and to left from shoulder. Remainder of possible petroglyphs are tally marks or faint geometric figures.

Cultural Materials Observed/Collected: None.

Shovel Test Data: None.

Assessment/Recommendations: Over $50 \%$ of site appears intact; it lacks associated subsurface deposits. Site has excellent research potential and is judged to be potentially eligible for listing on NRHP. Recommend detailed recording (see Table 37).

\section{$\underline{41 K T 69}$}

Location: Ca. $4.7 \mathrm{~km}$ SSE of confluence of Double Mountain Fork and Grape Creek, and $6.8 \mathrm{~km}$ ESE of confluence of Double Mountain Fork and Cat Hollow.

Description: Faunal locality on narrow alluvial terrace above Grape Creek and below bluff slope; elevation $2220 \mathrm{ft} \mathrm{msl}$, area $500 \mathrm{~m}^{2}$. Few bison bones exposed for length of ca. $50 \mathrm{~m}$ in cutbank of terrace, along with charcoal and ash lenses above bones. Bone fragments were found at $60-80 \mathrm{~cm}$, and lenses were at $\mathrm{ca} .40 \mathrm{~cm}$ below surface. No other evidence of cultural activity was found in fill screened from charcoal and ash lenses. Site could represent bison kill or jump. No temporal components 1dentified; undefined Prehistoric.

Features: None. 
Cultural Materials Observed/Collected: Bone fragments and charcoal/ash lenses. One charcoal sample collected (see Appendices A and B).

Shovel Test Data: None.

Assessment/Recommendations: Less than $50 \%$ of site appears intact; it contains subsurface deposits. Site has good research potential and is judged to be potentially eligible for listing on NRHP. Recommend mapping and testing.

\section{$\underline{41 K T 70}$}

Location: Ca. $4.7 \mathrm{~km}$ SSE of confluence of Double Mountain Fork and Grape Creek, and $6.9 \mathrm{~km}$ ESE of confluence of Double Mountain Fork and Cat Hollow.

Description: Lithic procurement area/open campsite on upland margin on top of small point overlooking Grape Creek; elevation 2280-2300 ft msl, area $2400 \mathrm{~m}^{2}$. Point is flanked by two drainages; top of point is deflated and eroded, with large fragments of bedrock and Quaternary gravels exposed on surface. Sparse artifact scatter with two burned rock features. Features and most debitage concentrated on north side of site on slopes. Small camping area with limited lithic procurement. No temporal components identified; undefined Prehistoric.

Features: Two ca. 100-cm-diameter clusters of burned sandstone.

Cultural Materials Observed/Collected: Core fragment, hammerstone, and flakes of Potter chert and Tecovas jasper. No collections made.

Shovel Test Data: One negative shovel test indicated soil depth of at least $100 \mathrm{~cm}$.

Assessment/Recommendations: Over $90 \%$ of site appears intact; it contains features but lacks subsurface deposits. Site has no research potentlal and is judged to be not eligible for listing on NRHP. No further work recommended.

\section{$\underline{41 K T 75}$}

Location: Ca. $5.2 \mathrm{~km}$ SSE of confluence of Double Mountain Fork and Grape Creek, and $6.9 \mathrm{~km}$ SE of confluence of Double Mountain Fork and Rocky Creek.

Description: Open campsite on lower alluvial terrace within point bar of Grape Creek; elevation 2220-2240 ft msl, area $36,000 \mathrm{~m}^{2}$. Artifact scatter including scraper and small amount of debitage, concentrated in small areas on both sides of point bar. Area disturbed by clearing, oil well, and dirt road. Little-used camping area with tool manufacture or refurbishing. No temporal components identified; undefined Prehistoric.

Features: None. 
Cultural Materials Observed/Collected: Snub-nosed end scraper of Edwards chert, secondary and tertiary flakes of Edwards chert, flake of quartzite, and flake of local chert. One item collected (see Appendices $A$ and B).

Shovel Test Data: One negative shovel test indicated soil depth of at least $95 \mathrm{~cm}$.

Assessment/Recommendations: Less than $10 \%$ of site appears intact; it lacks subsurface deposits. Site has no research potential and is judged to be not eligible for listing on NRHP. No further work recommended.

\section{$\underline{41 K T 77}$}

Location: Ca. $5.4 \mathrm{~km}$ SSE of confluence of Double Mountain Fork and Grape Creek, and $6.9 \mathrm{~km}$ SE of confluence of Double Mountain Fork and Cat Hollow.

Description: Open campsite on lower alluvial terrace above Grape Creek; elevation $2230 \mathrm{ft} \mathrm{msl}$, area unknown. Flake and burned rock fragment found in shovel test; no surface indications of site. Burned rock fragment is basis for classification as campsite. No temporal components identified; undefined Prehistoric.

Features: None.

Cultural Materials Observed/Collected: Edwards chert flake and fragment of burned sandstone. One item collected (see Appendices A and B).

Shovel Test Data: Two shovel tests excavated, one positive. Positive test yielded burned rock fragment at 0-20 cm and flake at $40-60 \mathrm{~cm}$, and indicated soll depth of at least $85 \mathrm{~cm}$. Negative test indicated soil depth of at least $100 \mathrm{~cm}$.

Assessment/Recommendations: Integrity of site is unknown; it contains subsurface deposits. Site has moderate research potential and is judged to be potentially eligible for listing on NRHP. Recommend mapping and testing.

\section{$41 \mathrm{KT} 78$}

Location: Ca. $5.8 \mathrm{~km}$ SSE of confluence of Double Mountain Fork and Grape Creek, and $5.1 \mathrm{~km}$ SE of confluence of Double Mountain Fork and Little Grape Creek.

Description: Open campsite on sloping and eroding alluvial terrace above Grape Creek; elevation 2240-2260 ft $\mathrm{msl}$, area $3500 \mathrm{~m}^{2}$. Small drainages run through site, forming two eroded and deflated ridges. Artifact scatter with burned rock clusters found primarily on tops of ridges. Most cultural deposits buried in alluvium and exposed by erosion and sheetwash. Camping area with plant processing. No temporal components identified; undefined Prehistoric, possibly Archaic.

Features: Seven ca. 75-100-cm-diameter clusters of burned sandstone fragments, most scattered and disturbed by erosion. 
Cultural Materials Observed/Collected: Untyped dart point of Edwards chert reworked into drill, sandstone mano fragments, cores and debitage of Potter chert and local chert, and fragments of burned sandstone. One item collected (see Appendices A and B).

Shovel Test Data: One shovel test yielded burned rock fragment at 20-30 cm and indicated soll depth of at least $90 \mathrm{~cm}$.

Assessment/Recommendations: Over 50\% of site appears intact; it contains features and subsurface deposits. Site has good research potential and is judged to be potentially eligible for listing on NRHP. Recommend controlled collection, mapping, and testing.

\section{$41 \mathrm{KT} 79$}

Location: Ca. $5.2 \mathrm{~km} \mathrm{SE}$ of confluence of Double Mountain Fork and Little Grape Creek, and $5.9 \mathrm{~km}$ SSE of confluence of Double Mountain Fork and Grape Creek.

Description: Open campsite on lower alluvial terrace above small tributary of Grape Creek; elevation $2240 \mathrm{ft} \mathrm{msl}$, area $160 \mathrm{~m}^{2}$. Midden deposit $30 \mathrm{~cm}$ thick exposed in cutbank of creek containing arrow point, beveled knife, debitage, and deer and bison bone fragments. Camping area with evidence of intensive use. Temporal component is Late Prehistoric, possibly Garza Complex.

Features: Midden deposit $20 \mathrm{~m}$ long and $30 \mathrm{~cm}$ thick is buried ca. 30-60 cm below surface. Marked by band of ashy gray-brown soil.

Cultural Materials Observed/Collected: Distal arrow point fragment of Edwards chert; alternately beveled knife of Alibates agate; debitage of Edwards chert, local chert, and sandstone; and fragments of deer and bison bones (includes one butchered long bone and one fetal element). Twenty-four items and two samples collected (see Appendices $\mathrm{A}, \mathrm{B}$, and C).

Shovel Test Data: One negative shovel test on terrace above midden indicated soil depth of at least $75 \mathrm{~cm}$.

Assessment/Recommendations: Over $50 \%$ of site appears intact; it contains subsurface deposits. Site has excellent research potential and is judged to be potentially eligible for listing on NRHP. Recommend mapping and testing.

\section{$\underline{41 \mathrm{KT} 80}$}

Location: Ca. $6.8 \mathrm{~km}$ SSE of intersection of Garza/Kent county line and Double Mountain Fork, and $4.9 \mathrm{~km}$ SE of confluence of Double Mountain Fork and Little Grape Creek.

Description: Open campsite on talus slope above confluence of Grape Creek and small side drainage; elevation $2240 \mathrm{ft} \mathrm{msl}$, area $400 \mathrm{~m}^{2}$. Gradual slope has colluvial gravels mixed with eolian sands. Sparse scatter of artifacts in radius of ca. 15-20 m around possible burned rock feature. Small campsite with some tool manufacture and possibly plant processing. No temporal components identified; undefined Prehistoric. 
Features: Ca. 100-cm-diameter cluster of burned sandstone fragments, tentatively identified as hearth.

Cultural Materials Observed/Collected: Unifaces, gouge, biface, two cores, and flakes of local, Edwards, and Potter chert. Three items collected (see Appendices A and B).

Shovel Test Data: One negative shovel test indicated soll depth of $\mathrm{ca} .70 \mathrm{~cm}$.

Assessment/Recommendations: Over $75 \%$ of site appears intact; it contains features but lacks subsurface deposits. Site has no research potential and is judged to be not eligible for listing on NRHP. No further work recommended.

\section{$\underline{41 K T 81}$}

Location: Ca. $5.1 \mathrm{~km}$ SSE of confluence of Double Mountain Fork and Little Grape Creek, and $7.3 \mathrm{~km}$ ESE of confluence of Double Mountain Fork and Rocky Creek.

Description: Open campsite in point bar of lower alluvial terrace above Grape Creek; elevation 2240-2265 ft msl, area 11,250 $\mathrm{m}^{2}$. Scatter of lithic artifacts with single feature and two burned rock scatters. Scatters are ca. $5 \mathrm{~m}$ in diameter and have been diffused by erosion and deflation. Site is somewhat deflated. Small camping area with tool manufacture and plant processing. No temporal components identified; undefined Prehistoric.

Features: Ca. 1.5-m-diameter cluster of burned sandstone fragments.

Cultural Materials Observed/Collected: Two drill fragments of Edwards and Potter chert, mano fragment, chert biface fragment, and cores and flakes of Potter chert and local chert. Three items collected (see Appendices A and B).

Shovel Test Data: One negative shovel test indicated soil depth of ca. $30 \mathrm{~cm}$.

Assessment/Recommendations: Over $75 \%$ of site appears intact; it contains features but lacks subsurface deposits. Site has moderate research potential and is judged to be potentlally eligible for listing on NRHP. Recommend mapping and testing.

\section{$\underline{41 \mathrm{KT} 82}$}

Location: Ca. $5.8 \mathrm{~km}$ SSE of confluence of Double Mountain Fork and Little Grape Creek, and $7.6 \mathrm{~km} \mathrm{SE}$ of confluence of Double Mountain Fork and Rocky Creek.

Description: Open campsite on lower alluvial terrace above Grape Creek; elevation 2230-2240 ft msl, area $300 \mathrm{~m}^{2}$. Terrace dissected by several small erosional gullies. Artifact scatter with concentration of burned rocks that could be eroded remains of feature. Most cultural materials found on surface of terrace. Possible small camping area. No temporal components identified; undefined Prehistoric. 
Features: None.

Cultural Materlals Observed/Collected: Unifacial chert tool (scraper); secondary and tertiary flakes of local and Edwards chert, Potter chert, and coarse-grained quartzite; and fragments of burned sandstone. No collections made.

Shovel Test Data: One negative shovel test indicated soll depth of at least $80 \mathrm{~cm}$.

Assessment/Recommendations: Over $90 \%$ of site appears intact; it lacks subsurface deposits. Site has no research potential and is judged to be not eligible for listing on NRHP. No further work recommended.

$\underline{41 K T 83}$

Location: Ca. $0.4 \mathrm{~km} \mathrm{NE}$ of northernmost intersection of Garza/Kent county line and Grape Creek, and $3.1 \mathrm{~km} \mathrm{NNE}$ of intersection of Garza/Kent county line and Garza/Kent/Scurry county line.

Description: Open campsite on upper alluvial terrace above Grape Creek; elevation $2260 \mathrm{ft} \mathrm{msl}$, area $15,000 \mathrm{~m}^{2}$. Cutbank on lower edge of terrace; few erosional gullies cut through terrace. Scatter of 11 thic artifacts with burned rock feature; most cultural materials in or near erosional areas. Disturbed slightly by dirt road which runs along upper edge of terrace. Small campsite with evidence of tool manufacture. No temporal components identified; undefined Prehistoric.

Features: One burned rock cluster ca. $100 \mathrm{~cm}$ in diameter composed of burned sandstone slabs ca. $18 \mathrm{~cm}$ long and small fragments of burned sandstone.

Cultural Materials Observed/Collected: Snub-nosed end scraper with evidence of hafting made of Edwards chert; unifacial tools, hammerstone, core, and flakes of Edwards chert, white fine-grained quartzite, and red coarse-grained quartzite; and fragments of burned sandstone. Three items collected (see Appendices A and B).

Shovel Test Data: One negative shovel test indicated soil depth of at least ca. 75 $\mathrm{Clm}$.

Assessment/Recommendations: Over $90 \%$ of site appears intact; it contains features but may lack subsurface deposits. Site has moderate research potential and is judged to be potentially eligible for listing on NRHP. Recommend mapping and testing.

\section{$41 \mathrm{KT} 84$}

Location: Ca. $0.2 \mathrm{~km}$ ESE of northernmost intersection of Garza/Kent county line and Grape Creek, and $2.9 \mathrm{~km}$ NNE of confluence of Garza/Kent county line and Garza/Kent/Scurry county line. 
Description: Open campsite on lower alluvial terrace above Grape Creek; elevation 2260-2280 ft msl, area $2500 \mathrm{~m}^{2}$. Historic dugout and extensive scatter of historic artifacts overlying prehistorlc scatter of lithic materials and burned rock features eroding out of lower edge of terrace. Temporal components are undefined Prehistoric and Historic (see Appendix G for description of historic component).

Features: Burned rock clusters.

Cultural Materials Observed/Collected: Lithic debitage and burned rocks. No collections made.

Shovel Test Data: None.

Assessment/Recommendations: Over $75 \%$ of prehistoric component appears intact; it contains features. Prehistoric component has unknown research potential and is judged to be potentially eligible for listing on NRHP. Recommend mapping, testing, and additional site recording.

ISOLATED FINDS

41GR245 is ca. $4.1 \mathrm{~km}$ SSE of confluence of Double Mountain Fork and Grape Creek, and $6.0 \mathrm{~km}$ ESE of confluence of Double Mountain Fork and Cat Hollow on upland promontory; elevation $2290 \mathrm{ft} \mathrm{msl}$, area less than $78.5 \mathrm{~m}^{2}$. Mano of red coarse-grained quartzite and small scraper of local chert on surface.

41 GR248 is ca. $1.7 \mathrm{~km} \mathrm{NE}$ of intersection of U.S. Highway 84 and FM 2458, and $2.8 \mathrm{~km} \mathrm{NW}$ of splllway of Justiceburg Lake at base of hill on lower alluvial terrace; elevation 2240 ft msl, area less than $78.5 \mathrm{~m}^{2}$. Several burned Potter chert cobbles and tested Potter chert cobble on surface.

41GR257 is ca. $2.1 \mathrm{~km}$ SSW of confluence of Double Mountain Fork and Little Grape Creek, and $3.8 \mathrm{~km} \mathrm{E}$ of confluence of Double Mountain Fork and Rocky Creek on upland point overlooking side canyon; elevation $2260 \mathrm{ft} \mathrm{msl}$, area $1590 \mathrm{~m}^{2}$. Two flakes (one Potter chert, one Edwards chert) and exhausted core of Edwards chert on surface.

41GR278 is ca. $2.2 \mathrm{~km} \mathrm{NE}$ of confluence of Double Mountain Fork and Rocky Creek, and $3.3 \mathrm{~km} \mathrm{~W}$ of confluence of Double Mountain Fork and Little Grape Creek on bedrock terrace on

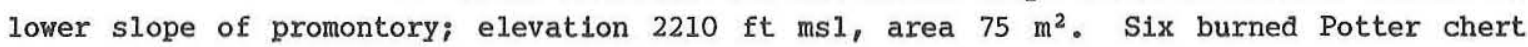
fragments and four possible flakes of local chert and red coarse-grained quartzite on surface.

41GR279 is ca. $2.3 \mathrm{~km} \mathrm{NE}$ of confluence of Double Mountain Fork and Rocky Creek, and $3.1 \mathrm{~km}$ W of confluence of Double Mountain Fork and Little Grape Creek on gravel-covered rise on upland margin; elevation $2245 \mathrm{ft} \mathrm{msl}$, area $1 \mathrm{~m}^{2}$. Scraper of Edwards chert on surface (collected, see Appendices A and B).

41GR299 is ca. $0.6 \mathrm{~km}$ WSW of confluence of Double Mountain Fork and Cat Hollow, and $1.8 \mathrm{~km} \mathrm{NNE}$ of confluence of Double Mountain Fork and Rocky Creek in gravel bed in bottom of side canyon; elevation $2175 \mathrm{ft} \mathrm{msl}$, area $1 \mathrm{~m}^{2}$. Unifacially worked Potter chert flake on surface. 
41GR301 is ca. $0.7 \mathrm{~km} \mathrm{NW}$ of confluence of Double Mountain Fork and Cat Hollow, and 2.4 $\mathrm{km}$ NNE of confluence of Double Mountain Fork and Rocky Creek on gently sloping uplands; elevation $2260 \mathrm{ft} \mathrm{msl}$, area $1200 \mathrm{~m}^{2}$. Thin scatter of burned Potter chert fragments on surface.

$41 \mathrm{GR} 335$ is ca. $4.5 \mathrm{~km}$ SSW of intersection of Garza/Kent county line and Double Mountain Fork, and $4.3 \mathrm{~km}$ ENE of confluence of Double Mountain Fork and Rocky Creek in small upland drainage; elevation $2240 \mathrm{ft} \mathrm{msl}$, area $1 \mathrm{~m}^{2}$. Rectangular planar tool of Potter chert on surface (collected, see Appendices $A$ and $B$ ).

$41 \mathrm{GR} 346$ is ca. $4.8 \mathrm{~km}$ SW of intersection of Garza/Kent county line and Double Mountain Fork, and $2.0 \mathrm{~km} \mathrm{~W}$ of confluence of Double Mountain Fork and Little Grape Creek on point on canyon rim; elevation $2230 \mathrm{ft} \mathrm{msl}$, area $24 \mathrm{~m}^{2}$. Two cores and flake of Potter chert on surface.

4IGR355 is ca. $4.6 \mathrm{~km}$ SW of intersection of Garza/Kent county line and Double Mountain Fork, and $2.0 \mathrm{~km}$ WNW of confluence of Double Mountain Fork and Little Grape Creek on three rises on canyon rim; elevation 2230-2250 ft $\mathrm{msl}$, area $6000 \mathrm{~m}^{2}$. Two flakes and burned fragments of Potter chert on surface.

41GR357 is ca. $2.8 \mathrm{~km}$ SSW of intersection of Garza/Kent county line and Double Mountain Fork, and $0.6 \mathrm{~km} \mathrm{E}$ of confluence of Double Mountain Fork and Little Grape Creek on small point on canyon rim; elevation $2260 \mathrm{ft} \mathrm{msl}$, area $1 \mathrm{~m}^{2}$. Fifty-cm-diameter cluster of burned sandstone and Potter chert fragments on surface.

41GR358 is ca. $0.6 \mathrm{~km}$ NNE of confluence of Double Mountain Fork and Little Grape Creek, and $1.8 \mathrm{~km} \mathrm{SW}$ of confluence of Double Mountain Fork and Grape Creek on small point on canyon rim; elevation $2250 \mathrm{ft} \mathrm{msl}$, area $78.5 \mathrm{~m}^{2}$. Two flakes and tested cobble of Potter chert on surface.

41GR382 is ca. 2.4 km NNW of confluence of Double Mountain Fork and Rocky Creek, and $1.8 \mathrm{~km}$ WNW of confluence of Double Mountain Fork and Cat Hollow on bedrock terrace; elevation $2240 \mathrm{ft} \mathrm{msl}$, area $21 \mathrm{~m}^{2}$. Chopper and secondary flake of Potter chert and burned sandstone cobble fragment on surface.

41GR404 is ca. $0.9 \mathrm{~km}$ NNE of confluence of Double Mountain Fork and Rocky Creek, and $4.3 \mathrm{~km}$ WSW of confluence of Double Mountain Fork and Little Grape Creek in erosional drainage cutting through terrace; elevation $2220 \mathrm{ft} \mathrm{msl,} \mathrm{area} 150 \mathrm{~m}^{2}$. Core and four tested cobbles of Potter chert and core and six flakes of red coarse-grained quartzite on surface.

41GR411 is ca. $1.2 \mathrm{~km} \mathrm{NW}$ of confluence of Double Mountain Fork and Rocky Creek, and $2.4 \mathrm{~km}$ WSW of confluence of Double Mountain Fork and Cat Hollow on narrow alluvial terrace; elevation $2210 \mathrm{ft} \mathrm{msl}$, area $1960 \mathrm{~m}^{2}$. Two Edwards chert flakes, one burned sandstone fragment, and two bone fragments on surface.

41GR421 is ca. $0.3 \mathrm{~km}$ E of confluence of Double Mountain Fork and Rocky Creek, and 2.1. $\mathrm{km}$ SSW of confluence of Double Mountain Fork and Cat Hollow on knoll on canyon rim; elevation $2260 \mathrm{ft} \mathrm{msl}$, area $176 \mathrm{~m}^{2}$. Four flakes of local chert and one flake of red coarsegrained quartzite on surface. 
41GR436 is ca. $1.7 \mathrm{~km}$ SSW of confluence of Double Mountain Fork and Rocky Creek, and $5.9 \mathrm{~km}$ SW of confluence of Double Mountain Fork and Little Grape Creek on bluff slope; elevation $2280 \mathrm{ft} \mathrm{msl}$, area $1 \mathrm{~m}^{2}$. Scraper made from Edwards chert flake on surface.

41GR447 is ca. $1.7 \mathrm{~km}$ SSW of confluence of Double Mountain Fork and Rocky Creek, and $6.2 \mathrm{~km}$ SW of confluence of Double Mountain Fork and Little Grape Creek in cutbank; elevation $2210 \mathrm{ft} \mathrm{msl}$, area $1 \mathrm{~m}^{2}$. Bison long bone fragments in cutbank.

41GR452 is ca. $1.5 \mathrm{~km}$ SSW of confluence of Double Mountain Fork and Rocky Creek, and $6.2 \mathrm{~km} \mathrm{SW}$ of confluence of Double Mountain Fork and Little Grape Creek on erosional remnant knoll; elevation $2240 \mathrm{ft} \mathrm{msl}$, area 15,000 $\mathrm{m}^{2}$. Three Edwards chert flakes and one bone fragment on surface.

41GR461 is ca. $4.4 \mathrm{~km}$ SE of U.S. Highway 84 bridge over Double Mountain Fork, and 1.7 $\mathrm{km} \mathrm{NE}$ of U.S. Highway 84 bridge at Sand Creek on alluvial terrace; elevation $2240 \mathrm{ft} \mathrm{msl}$, area $1 \mathrm{~m}^{2}$. Ensor dart point of Edwards chert on surface (collected, see Appendices $A$ and B); temporal component is late Archaic.

41GR463 is ca. $0.7 \mathrm{~km}$ NW of confluence of Double Mountain Fork and Sand Creek, and 5.0 $\mathrm{km}$ SE of intersection of U.S. Highway 84 and FM 2458 in alluvial terrace; elevation $2260 \mathrm{ft}$ $\mathrm{msl}$, area $19 \mathrm{~m}^{2}$. Two bison bones in cutbank.

41 GR468 is ca. $4.2 \mathrm{~km}$ SW of intersection of U.S. Highway 84 and FM 2458 , and $4.7 \mathrm{~km} \mathrm{~N}$ of U.S. Highway 84 bridge at Sand Creek in lower alluvial terrace; elevation $2230 \mathrm{ft} \mathrm{msl}$, area $1 \mathrm{~m}^{2}$. Bison bone fragment in cutbank.

41 GR469 is ca. $4.3 \mathrm{~km} \mathrm{SE}$ of intersection of U.S. Highway 84 and FM 2458 , and $2.4 \mathrm{~km} \mathrm{~N}$ of U.S. Highway 84 bridge at Sand Creek in lower alluvial terrace; elevation $2235 \mathrm{ft} \mathrm{msl}$, area $1 \mathrm{~m}^{2}$. B1son bone in cutbank.

41 GR482 is ca. $8.6 \mathrm{~km}$ NE of confluence of Double Mountain Fork and Salt Branch, and $11.1 \mathrm{~km} \mathrm{NNE}$ of confluence of Double Mountain Fork and Red Branch on upland plain; elevation $2370 \mathrm{ft} \mathrm{msl}$, area $1 \mathrm{~m}^{2}$. Prehistoric ceramic sherd found on surface (collected, see Appendices $\mathrm{A}$ and $\mathrm{B})$; temporal component is Late Prehistoric.

$41 \mathrm{GR} 486$ is ca. $2.2 \mathrm{~km} \mathrm{NE}$ of confluence of Double Mountain Fork and Red Branch, and 6.7 $\mathrm{km}$ E of U.S. Highway 84 bridge over Double Mountain Fork in eroded drainage at upland margin; elevation $2280 \mathrm{ft} \mathrm{msl}$, area $1256 \mathrm{~m}^{2}$. Tested Edwards chert cobble, local chert flake, and burned Potter chert fragment on surface.

$41 \mathrm{GR} 492$ is ca. $1.8 \mathrm{~km}$ NNE of confluence of Double Mountain Fork and Rocky Creek, and $3.6 \mathrm{~km}$ WSW of confluence of Double. Mountain Fork and Little Grape Creek on upland margin knoll; elevation $2265 \mathrm{ft} \mathrm{msl}$, area $800 \mathrm{~m}^{2}$. Three flakes of Edwards chert and flake of local chert on surface.

41GR496 is ca. $6.9 \mathrm{~km}$ ESE of intersection of U.S. Highway 84 and FM 2458 , and $1.7 \mathrm{~km}$ NNE of confluence of Double Mountain Fork and Red Branch on upland margin; elevation 2260 $\mathrm{ft}$, area $75 \mathrm{~m}^{2}$. Potter chert core, tested Potter chert cobble, possibly tested opalized wood cobble, and possibly burned sandstone fragment on surface. 
$41 \mathrm{GR} 498$ is ca. $7.1 \mathrm{~km}$ ESE of Intersection of U.S. Highway 84 and FM 2458 , and $1.4 \mathrm{~km}$ NNE of confluence of Double Mountain Fork and Red Branch on small point on upland margin; elevation $2260 \mathrm{ft} \mathrm{msl}$, area $78.5 \mathrm{~m}^{2}$. Flake and tested cobble of Potter chert and tested cobble of posstble opalized wood on surface.

41GR499 is ca. $7.0 \mathrm{~km}$ ESE of intersection of U.S. Highway 84 and FM 2458 , and $1.4 \mathrm{~km}$ NNE of confluence of Double Mountain Fork and Red Branch on slope just above canyon rim; elevation $2260 \mathrm{ft} \mathrm{msl}$, area $1 \mathrm{~m}^{2}$. Unifacially flaked cobble of coarse-grained quartzite near ca. $70 \mathrm{~cm}$ diameter cluster of unburned sandstone cobbles on surface.

41GR500 is ca. $6.4 \mathrm{~km}$ ESE of intersection of U.S. Highway 84 and FM 2458 , and $1.5 \mathrm{~km}$ ENE of confluence of Double Mountain Fork and Sand Creek on point on upland margin; elevation $2280 \mathrm{ft} \mathrm{msl}$, area $300 \mathrm{~m}^{2}$. Two tertlary flakes (one of Potter chert, one of Edwards chert) and four tested cobbles of local chert on surface.

41GR501 is ca. $6.5 \mathrm{~km}$ ESE of intersection of U.S. Highway 84 and FM 2458 , and ca. 1.0 $\mathrm{km}$ NNE of confluence of Double Mountain Fork and Red Branch on narrow ridge on upland margin; elevation $2260 \mathrm{ft} \mathrm{msl}$, area $200 \mathrm{~m}^{2}$. Burned local chert flake, and ca. $60-\mathrm{cm}-$ diameter cluster of three burned Potter chert fragments, burned sandstone fragment, and limestone cobbles on surface near depression.

41GR502 is ca. $6.8 \mathrm{~km} \mathrm{SE}$ of intersection of U.S. Highway 84 and FM 2458, and $0.8 \mathrm{~km} \mathrm{NE}$ of confluence of Double Mountain Fork and Red Branch in lower alluvial terrace; elevation $2220 \mathrm{ft} \mathrm{msl}$, area $9 \mathrm{~m}^{2}$. Mano in bottom of gully (collected, see Appendices $\mathrm{A}$ and $\mathrm{B}$ ) and flake and possibly burned sandstone slabs in cutbank $40 \mathrm{~cm}$ below surface.

41 GR508 is ca. $1.2 \mathrm{~km}$ WNW of confluence of Double Mountain Fork and Rocky Creek, and $1.9 \mathrm{~km}$ SW of confluence of Double Mountain Fork and Gobbler Creek at base of high bluff face forming shallow overhang; elevation $2240 \mathrm{ft} \mathrm{msl}$, area $18 \mathrm{~m}^{2}$. Edwards chert scraper on surface (collected, see Appendices A and B).

41GR510 is ca. $1.5 \mathrm{~km} \mathrm{~W}$ of confluence of Double Mountain Fork and Rocky Creek, and 2.2 $\mathrm{km}$ SW of confluence of Double Mountain Fork and Gobbler Creek on slope below upland point; elevation $2230 \mathrm{ft} \mathrm{msl}$, area $700 \mathrm{~m}^{2}$. Two flakes and tested cobble of local chert, core of red coarse-grained quartzite, and burned Potter chert fragment on surface.

41 GR519 is ca. $3.0 \mathrm{~km} \mathrm{NE}$ of U.S. Highway 84 bridge over Sand Creek, and $0.7 \mathrm{~km} \mathrm{SE}$ of confluence of Double Mountain Fork and Red Branch on erosional remnant terrace; elevation $2230 \mathrm{ft} \mathrm{msl}$, area $1500 \mathrm{~m}^{2}$. Chopper and flake of Potter chert, tertiary flake of Edwards chert, and tertiary flake of clear quartz on surface.

41GR532 is ca. $3.8 \mathrm{~km}$ SSE of U.S. HIghway 84 bridge over Double Mountain Fork, and 1.3 $\mathrm{km}$ NNE of U.S. Highway 84 bridge over Sand Creek on lower alluvial terrace; elevation 2230 ft $\mathrm{msl}$, area $120 \mathrm{~m}^{2}$. Few bison bone fragments (including parts of mandible and vertebra) in cutbank and bottom of gully.

41 GR535 is ca. $3.7 \mathrm{~km}$ SE of U.S. Highway 84 bridge over Double Mountain Fork, and 1.7 $\mathrm{km}$ NNE of U.S. Highway 84 bridge over Sand Creek on small hill on lower alluvial terrace; elevation $2240 \mathrm{ft} \mathrm{msl}$, area $1 \mathrm{~m}^{2}$. Sandstone mano on surface. 
41GR561 is ca. $3.4 \mathrm{~km}$ ESE of intersection of U.S. Highway 84 and FM 2458 , and $2.4 \mathrm{~km} \mathrm{E}$ of U.S. Highway 84 bridge over Double Mountain Fork on bedrock terrace; elevation $2240 \mathrm{ft}$ msl, area $75 \mathrm{~m}^{2}$. Potter chert chopper and fragmentary cobbles of Potter chert, coarsegrained quartzite, and local chert on surface.

$41 \mathrm{KT} 39$ is ca. $1.0 \mathrm{~km} \mathrm{E}$ of confluence of Double Mountain Fork and Grape Creek, and 1.7 $\mathrm{km}$ SSW of confluence of Double Mountain Fork and South Sage Creek on upland margin; elevation $2250 \mathrm{ft} \mathrm{msl}$, area $7 \mathrm{~m}^{2}$. Potter chert gouge and unifacially edge-trimmed flake of black Ogallala quartzite on surface (collected, see Appendices A and B).

$41 \mathrm{KT} 46$ is ca. $3.1 \mathrm{~km}$ SSW of confluence of Double Mountain Fork and South Sage Creek, and $1.9 \mathrm{~km}$ SSE of confluence of Double Mountain Fork and Grape Creek on small rise in uplands; elevation $2280 \mathrm{ft} \mathrm{msl}$, area $3000 \mathrm{~m}^{2}$. Potter chert core and possibly ground sandstone fragment on surface.

$41 \mathrm{KT} 48$ is ca. $3.3 \mathrm{~km}$ SSW of confluence of Double Mountain Fork and South Sage Creek, and $2.9 \mathrm{~km} \mathrm{E}$ of confluence of Double Mountain Fork and Little Grape Creek on point on canyon rim; elevation 2265-2270 ft msl, area $75 \mathrm{~m}^{2}$. Core and battered cobble of red coarse-grained quartzite on surface.

41KT59 is ca. $3.1 \mathrm{~km}$ SSE of confluence of Double Mountain Fork and Grape Creek, and $6.3 \mathrm{~km}$ SSE of confluence of Double Mountain Fork and Cat Hollow on edge of canyon rim; elevation $2260 \mathrm{ft} \mathrm{msl}$, area $1 \mathrm{~m}^{2}$. Nolan dart point of local chert on surface (collected, see Appendices A and B); temporal component is middle Archalc.

41KT64 is ca. $4.0 \mathrm{~km}$ SSE of confluence of Double Mountain Fork and Grape Creek, and $6.6 \mathrm{~km}$ ESE of confluence of Double Mountain Fork and Rocky Creek on lower alluvial terrace; elevation $2190 \mathrm{ft} \mathrm{msl}$, area $1 \mathrm{~m}^{2}$. Quartzite mano on surface.

$41 \mathrm{KT71}$ is ca. $4.9 \mathrm{~km}$ SSE of confluence of Double Mountain Fork and Grape Creek, and $6.9 \mathrm{~km}$ ESE of confluence of Double Mountain Fork and Cat Hollow on lower alluvial terrace; elevation $2200 \mathrm{ft} \mathrm{msl}$, area $800 \mathrm{~m}^{2}$. Three bison bone fragments (two from metatarsals) in cutbank at $40 \mathrm{~cm}$ below surface.

$41 \mathrm{KT74}$ is ca. $5.1 \mathrm{~km}$ SSE of confluence of Double Mountain Fork and Grape Creek, and $4.5 \mathrm{~km}$ SE of confluence of Double Mountain Fork and Little Grape Creek on talus slope just below canyon rim; elevation $2270 \mathrm{ft} \mathrm{msl}$, area $1 \mathrm{~m}^{2}$. Bedrock mortar hole in sandstone boulder, triangular at top and oval at bottom, measuring $21 \mathrm{~cm}$ long, $20 \mathrm{~cm}$ wide, and $10 \mathrm{~cm}$ deep. 
REFERENCES CITED

Kirkpatrick, Zoe

1978 A Preliminary Report on a Rare Form of Bedrock Mortar Holes in Garza County, Texas. Transactions of the Thirteenth Regional Archeological Symposium for Southeastern New Mexico and Western Texas:31-38.

Riggs, Aaron D., Jr.

1965 Petroglyphs of Garza County, Texas. Transactions of the First Regional Archeological Symposium for Southeastern New Mexico and Western Texas:9-14.

1966 The Reed Shelter: A Petroglyph Site in Garza County, Texas. Transactions of the Second Regional Archeological Symposium for Southeastern New Mexico and Western Texas:44-58. 



\section{APPENDIX G: Historic Site Descriptions}

William A. Bryan,

Martha Doty Freeman, and

Margaret Ann Howard 



\section{INTRODUCTION}

The historic site descriptions are divided into two sections: Garza County and Kent County. The descriptions are organized by county in alphabetical order and in numerical order of site within each county. Information for each site is organized into seven headings: location, description, features, cultural materials observed/collected, shovel test data, site history, and assessment/recommendations. All sites are described fully in a telegraphic format in order to conserve space with the exception of the site history and assessment/recommendations headings. This information is provided in full text (site histories are not given for historic rock art sites). Assessments are based on each site's individual merits and are stated in terms of eligibility for listing on the National Register of Historic Places. These assessments were made by the Project Historian, Project Archeologist, and Principal Investigator based on a site-by-site review. Two categories of eligibility include: potentially eligible (sites with excellent to unknown research potential, sites associated with significant events or persons, or sites have significant standing architecture), and not eligible (sites with little or no further research potential, those lacking significant associations, or those lacking significant standing architecture). Research potential is derived from each site's potential to contribute to the resolution of the questions posed in the Research Design (Chapter 5). Sites with unknown potential are those that falled to yield temporally or functionally diagnostic materials. The "unknown" designation refers to the inability (based on extant data) to specify which research questions a site may appropriately address rather than a lack of any research potential. Recommendations are provided on the basis of each site's assessment. These do not consider the suggested sampling strategy described in Chapter 13, Recommendations/ Treatment Plan.

As with the prehistoric site descriptions (Appendix F), abbreviations are used. Those referring to roads, distances, elevations, and cardinal directions are self-explanatory. However, two others require explanation. GRC refers to Grand River Consultants, Inc., a firm located in Grand River, Colorado, which performed limited archeological survey at Justiceburg in 1982. NRHP refers to the National Register of Historic Places; this phrase is abbreviated to save space since it must be used in the assessments of each individual site.

GARZA COUNTY SITES

$\underline{41 G R 13}$

Location: Ca. $1.6 \mathrm{~km} \mathrm{E}$ of intersection of U.S. Highway 84 and FM 2458 , and $1.4 \mathrm{~km} \mathrm{NE}$ of U.S. Highway 84 bridge over Double Mountain Fork.

Description: Ranch headquarters site on eroding upland margin and lower alluvial terrace overlooking Salt Branch; elevation 2240-2260 ft msl, area 10,000 $\mathrm{m}^{2}$. Upland area is deflated; alluvial terrace is less deflated, although soils are fairly shallow. First recorded by Emmett Shedd in 1976, rerecorded by GRC in 1982; however, neither reported historic component. Current investigations noted historic component consisting of house complex and scatter of historic artifacts. Historic component believed to date to 1930 s or 
1940s. Temporal components are Historic, late Archaic, and Late Prehistoric (see Appendix F for description of prehistoric components).

Features: House complex is in north part of site on lower alluvial terrace; it includes fenced-in residence area, shed made from railroad car, corral, and stock tank. Stack of railroad ties just north of tank has two date nails: 1928 and 1941. House and buildings are not inhabited but are maintained. Fenced-in residence area roughly $80 \mathrm{ft}$ north-south by $830 \mathrm{ft}$ east-west contains large house with asphalt-shingle siding and smaller wooden house (both apparently brought in), concrete water tank, and garage with tin roof.

Cultural Materials Observed/Collected: Whiteware fragments (both plain and painted), clear and blue bottle glass fragments, milk glass fragments, and tin cans. No collections made.

Shovel Test Data: One negative shovel test in house complex found clay soils to 30 $\mathrm{cm}$.

Site History: Site 41GR13 is located in Section 21, Block 6. The Section was surveyed on August 3, 1873, and patented to the Houston and Great Northern Railroad Company on December 27, 1873 (Texas. General Land Office 1873f).

Deed records for Garza County do not include a copy of a conveyance to a private owner prior to 1912, at which point Lora H. and David F. Jones of Palmyra County, Ohio, sold Section 21 to Arthur E. Tuffing of Denver, Colorado, for \$848.55 (Garza County Deed Record 14:548-549). The Tuffing family has kept possession of the property until the present day.

While Section 21 is the location of an historic house, it is not the site of the Tuffing family's first home near Justiceburg. According to an article in The Post Dispatch (September 12, 1957:3), the Arthur Tuffings left Ohio in 1901 to settle in West Texas. They traveled first by train to Colorado City, where they lived briefly, then moved to Section 10, Block 6, located immediately east of site 41GR13 which an earlier occupant, T. J. Payne, sold to them on May 22, 1901 (Garza County Deed Record 7:222). The family made camp in an old prairie dog home on the section because the few small mesquite trees there would offer shade, but they soon discovered that the prairie dogs had moved out and the snakes had moved in. Home consisted of a tent in which they kept their food, bedding, and clothes; the family slept out in the open. Drinking water was hauled in a burned-out whiskey barrel from a cattle tank 2 miles away.

A year after they settled on Section 10, the Tuffings purchased the land from the State (Garza County Deed Record 8:45-46). They apparently built a home soon after, which became the location of the first post office in the area. The post office name, Leforest, was a combination of the two Tuffing boys' names, Lee and Forrest, and it was adopted as the name of the first school in the area, which also was located on the Tuffings' land.

In about 1912, the Tuffings had financial problems, and they were forced to move to Denver to get work. It seems to have been during this trip that they purchased the adjoining Section 21 on which $41 \mathrm{GR} 13$ is located. The Tuffings then returned home and continued to live on Section 10 while using Section 21 for farming and/or grazing. 
In the late 1920s, the Tuffings conveyed Section 21 to their son Forrest, who occupled a house at site 41GR250 located west of 41GR13 (Nance 1987). At an as-yet-undetermined date, Forrest Tuffing or his widow moved the building to its present location at $41 \mathrm{GR} 13$, and the family continued to occupy it (Garza County Tax Assessors Abstracts; Nance 1987). Today, the property is owned by a granddaughter (Nance 1987).

Assessment/Recommendations: While site $41 \mathrm{GR} 13$ is not known to be associated with significant persons or events at this time, the house which is a part of the site is a frame structure which may be 50 or more years old. Information gathered in 1987 suggests that the structure may have been moved from Burnham, an historic townsite located ca. 1 mile east of site 41GR13, but its history and morphology are only incompletely understood. Over $90 \%$ of the historic component appears intact; it contains standing structures but may lack subsurface deposits. The historic component is judged to be potentially eligible for listing on the NRHP according to Criteria C and D. It is recommended, therefore, that further site assessment consist of a thorough mapping of the site, gathering of data from local informants and family members, and investigation of the house at $41 \mathrm{GR} 13$ to determine a likely date of construction and to assess the possibility that the structure dates to the period when Burnham townsite was occupied (for a history of the Burnham townsite, see Site History for 41GR331).

41 GR33

Location: $\mathrm{Ca} .2 .8 \mathrm{~km}$ ESE of intersection of U.S. Highway 84 and FM 2458 , and $1.9 \mathrm{~km}$ ENE of U.S. Highway 84 bridge over Double Mountain Fork.

Description: Trash dump on eroding upland margin point near canyon rim over Double Mountain Fork; elevation 2240-2260 ft msl, area $75 \mathrm{~m}^{2}$. Part of prehistoric site first reported by Emmett Shedd and later recorded by GRC, who did not document historic component. Current investigations found few whiteware and glass fragments on surface. Historic inscriptions (41GR557 and 41GR558) on bluffs below point. Temporal components are Historic, Archaic, and Late Prehistoric (see Appendix F for description of prehistoric components).

Features: None.

Cultural Materials Observed/Collected: Four fragments of plain whiteware and few fragments of glass. No collections made.

Shovel Test Data: None.

Site History: See Site History for 41 GR474 for history of tract.

Assessment/Recommendations: Site 41GR33, which is located on the Jeff D. Justice homestead tract, appears to be the result of random historic activity. It is located across the river from the Justice dugout and housesite (41GR474), and so it seems unlikely that 41 GR33 represents a dump associated with 41 GR 474 even though it is on land owned by the Justice family. Less than $20 \%$ of the historic component appears intact; it lacks subsurface deposits. The historic component has a low research potential and is judged to be not eligible for listing on the NRHP. No further work is recommended. 


\section{GR51 (Dorward Ranch Site)}

Location: Ca. $0.3 \mathrm{~km}$ ESE of confluence of Double Mountain Fork and Rocky Creek, and $2.1 \mathrm{~km}$ SSW of confluence of Double Mountain Fork and Cat Hollow.

Description: Rock art site on vertical sandstone face on bluffs overlooking head of small drainage flowing into Double Mountain Fork; elevation 2200-2220 ft msl, area $2000 \mathrm{~m}^{2}$. First recorded by Aaron Riggs in 1965, who described rock art in detail (Riggs 1965). Current investigations noted numerous historic inscriptions in addition to aboriginal rock art. Historic inscriptions represent considerable length of time and have names of people known historically in area. Site area is well-known and often-visited spot for sightseers and picnickers. Temporal components are Historic aboriginal and nonaboriginal (see Appendix F for description of aboriginal component).

Features: Historic inscriptions in three areas. First consists of large vertical sandstone face ca. $15 \mathrm{~m}$ wide and $8 \mathrm{~m}$ tall covered with hundreds of historic inscriptions and recent graffiti, obscuring and sometimes destroying aboriginal petroglyphs. 0ldest inscription reads "EARL JUSTICE DEC. 5.-15" (1915) and measures $95 \mathrm{~cm}$ long and $22 \mathrm{~cm}$ tall; others range from that date to present.

Second area under sandstone ledge near first area contains large number of historic inscriptions and modern graffiti. Oldest historic inscription reads " $\mathrm{C}$ Burns, July 21 , 1883" and measures $127 \mathrm{~cm}$ long and $18 \mathrm{~cm}$ tall; rest of inscriptions range from that date to present.

Third area in overhang on bend of drainage facing north and northwest; contains two historic inscriptions: "E. S. JACKSON 1889" and "SALLIE WILLIAMS JUNE 28, 1900." In latter inscription, "1900" has been scratched out and "1911" added below. Area also contains recent graffit1. For further information about inscriptions, see Appendix E.

Cultural Materials Observed/Collected: None.

Shovel Test Data: None.

Assessment/Recommendations: This site contains numerous historic inscriptions by persons of note in the history of the Justiceburg area. The inscriptions are rapidly being obliterated by vandalism and are nearing a state of complete destruction. Over $90 \%$ of the historic inscriptions appear intact; they lack associated subsurface deposits. The historic inscriptions have research potential and are judged to be potentially eligible for listing on the NRHP. It is very strongly recommended that the inscriptions be fully documented with photographs and detailed drawings, and that an effort be made to protect the site from further damage.

\section{GR54 (Reed Shelter)}

Location: Ca. $2.4 \mathrm{~km}$ NNW of confluence of Double Mountain Fork and Rocky Creek, and $2.0 \mathrm{~km}$ WNW of confluence of Double Mountain Fork and Cat Hollow. 
Description: Rock art site in and around rockshelter eroded from base of bluff overlooking Gobbler Creek; elevation $2240 \mathrm{ft} \mathrm{msl}$, area $450 \mathrm{~m}^{2}$. First recorded, excavated, and reported by Aaron Riggs (1966), who reported that rock face outside shelter bore historic inscriptions. Emmett Shedd later visited site, and GRC rerecorded site in 1982. Temporal components are Historic and Late Prehistoric (see Appendix F for description of prehistoric component).

Features: Two panels of historic inscriptions. One panel contains initials "V A H" and " $\mathrm{C} \mathrm{A} \mathrm{H"} \mathrm{and} \mathrm{two} \mathrm{vague} \mathrm{drawings} \mathrm{or} \mathrm{figures} \mathrm{too} \mathrm{eroded} \mathrm{to} \mathrm{decipher.} \mathrm{"V} \mathrm{A} \mathrm{H"} \mathrm{is} \mathrm{arranged}$ so that " $\mathrm{V}$ " is drawn above "A $\mathrm{H}$ " and has arm extending from left side like Wing. "A $\mathrm{H}$ " drawn with shared vertical line.

Second panel contains four undated initial sets, oval, and date with set of initials which could also be brand mark. Undated initials are "M.W.," "M V W," "ME," and "D.B." "M V W" has two short tally marks below it. Dated inscription reads "8/26/16 S M S." Letters could be brand mark of Swenson Ranch. Oval figure could be aboriginal petroglyph. For further information about initials, names, or symbols, see Appendix E.

Cultural Materials Observed/Collected: None.

Shovel Test Data: None.

Assessment/Recommendations: Over $90 \%$ of the historic inscriptions appear intact; they lack associated subsurface deposits. The historic inscriptions have research potential and are judged to be potentially eligible for listing on the NRHP. However, initial field recording has exhausted the site's potential at this time, and no further work is recommended.

\section{$\underline{41 G R 203}$}

Location: Ca. $3.2 \mathrm{~km} \mathrm{SE}$ of intersection of U.S. Highway 84 and FM 2458 , and $2.6 \mathrm{~km}$ northwest of confluence of Double Mountain Fork and Sand Creek.

Description: Housesite on upland point overlooking Double Mountain Fork and Lake Justiceburg spillway; elevation 2240-2280 ft msl, area $600 \mathrm{~m}^{2}$. First recorded by Emmett Shedd in 1977, who reported prehistoric component and recent/historic component consisting of house and garden. Current investigations noted burned housesite and scatter of historic debris. Historic component is related to Sante Fe Lake Complex (Justiceburg Lake), although most historic materials are recent. Temporal components are Historic, Archaic, and Late Prehistoric (see Appendix F for description of prehistoric components).

Features: House (recently burned) and dirt road.

Cultural Materials Observed/Collected: Barbed wire, fragments of beer bottle glass, and other recent historic debris. No collections made.

Shovel Test Data: None.

Site History: For history of site 41GR203, see site 41GR470, Santa Fe Lake (Justiceburg Lake) Complex. 
Assessment/Recommendations: Less than $50 \%$ of the historic component appears intact; it may lack subsurface deposits. The historic component has an unknown research potential but is judged to be potentially eligible for listing on the NRHP according to Criteria A and D. It is recommended that the site, which was the location of a caretaker's house associated with the Santa Fe Lake Complex (Blakey 1987), be mapped and an attempt made to locate and interview former residents.

\section{$\underline{41 G R 242}$}

Location: Ca. $5.1 \mathrm{~km} \mathrm{~S}$ of confluence of the Double Mountain Fork and Grape Creek, and $6.7 \mathrm{~km}$ ESE of confluence of Double Mountain Fork and Rocky Creek.

Description: Rock art site on vertical sandstone face on bluff above Grape Creek; elevation 2260-2280 ft msl, area $5 \mathrm{~m}^{2}$. Vertical face is roughly $8 \mathrm{~m}$ high and $5 \mathrm{~m} \mathrm{long}$. Several panels of historic inscriptions date from 1894 to 1929. Temporal component is Historic.

Features: Seven inscriptions on rock face, four with dates. First dated inscription is ca. $31 \mathrm{~cm}$ long and $15 \mathrm{~cm}$ tall and reads "MARCH 13, 1894." Second inscription, $150 \mathrm{~cm}$ to right, is $24 \mathrm{~cm}$ long and ca. $20 \mathrm{~cm}$ tall and reads "1929 EML." Third, $170 \mathrm{~cm}$ farther to right, is $50 \mathrm{~cm}$ long and ca. $45 \mathrm{~cm}$ tall and contains date "APR 2 1914," with initials "W.R.C." below month and heart with arrow through it under year. Initials are surrounded by rectangle, and six 12-cm-long parallel horizontal lines are drawn above month. Fourth dated inscription reads "EML 1929" and evidently is author of second inscription revisiting site in same year. Remaining inscriptions are undated initials reading "LLL," "M," and "N." For further information about inscriptions, see Appendix E.

Cultural Materials Observed/Collected: None.

Shovel Test Data: None.

Assessment/Recommendations: Over $90 \%$ of the site appears intact; it lacks associated subsurface deposits. The site has research potential and is judged to be potentially eligible for listing on the NRHP. However, the initial field recording has exhausted the site's potential at this time, and no further work is recommended.

\section{GR244}

Location: Ca. $4.3 \mathrm{~km} \mathrm{~S}$ of confluence of Double Mountain Fork and Grape Creek, and 6.5 $\mathrm{km}$ ESE of confluence of Double Mountain Fork and Rocky Creek.

Description: Rock art site in small rockshelter eroded from sandstone bluff overlooking side drainage of Grape Creek; elevation $2250 \mathrm{ft} \mathrm{msl}$, area $0.18 \mathrm{~m}^{2}$. Two elements of historic rock art. Temporal component is Historic.

Features: Two historic inscriptions $120 \mathrm{~cm}$ apart. One ca. $8.5 \mathrm{~cm}$ wide and $7.5 \mathrm{~cm}$ tall depicts initials "AB," with left leg of "A" serving as back of "B," possibly a brand 
symbol. Other is diagonal line ca. $6 \mathrm{~cm}$ long. For further information about inscriptions, see Appendix E.

Cultural Materials Observed/Collected: None.

Shovel Test Data: None.

Assessment/Recommendations: Over 90\% of the site appears intact; it lacks associated subsurface deposits. The site has research potential and is judged to be potentially eligible for listing on the NRHP. However, the initial field recording has exhausted the site's potential at this time, and no further work is recommended.

41GR250

Location: Ca. $0.8 \mathrm{~km} \mathrm{NNW}$ of confluence of Double Mountain Fork and Salt Branch, and $1.3 \mathrm{~km}$ ENE of intersection of U.S. Highway 84 and FM 2458.

Description: Housesite on end of eroding upland ridge over alluvial terraces above Salt Branch; elevation 2240-2260 ft msl, area $5000 \mathrm{~m}^{2}$. RIdge contains prehistoric and historic components; historic component consists of scatter of historic artifacts. Area has been cleared, and any structure once present has either been bulldozed or moved. Site dated to first half of twentieth century. Temporal components are Historic and undefined Prehistoric (see Appendix F for description of prehistoric component).

Features: Single possible structural feature is small depression $16 \mathrm{ft}$ long, $10 \mathrm{ft}$ wide, and ca. 20 inches deep located at edge of artifact scatter near edge of ridge.

Cultural Materials Observed/Collected: Brick fragments labeled "FERRIS," whiteware fragments with polychrome floral transfer decoration, plain whiteware fragments, clear glass machinemade panel bottle, two enameled tin coffee pots, metal fork, clear drinking glass base, clear bottle and jar glass fragments, light green window glass fragments, manganese purple glass fragments, barbed wire fragments, red rubber fragments, steel pipe fragment, sanitary-type tin cans, and miscellaneous fragments of metal and glass. No collections made.

Shovel Test Data: One shovel test yielded only prehistoric materials but found soil depth of ca. $80 \mathrm{~cm}$.

Site History: Site 41GR250 is the original location of the Forrest Tuffing home (Nance 1987), a structure which formerly may have been a store building. The history of the site is the same as that of $41 G R 13$ until the date of the move. While Forrest Tuffing did not receive Survey 21 on which 41 GR250 is located until the late 1920s, an increase in the property valuation of approximately 35\% between 1920 and 1921 suggests that the Arthur Tuffings may have moved the structure in at that date.

Assessment/Recommendations: At the present time, little is known about the specific components of the site or the duration of its occupation. There is a great amount of historic materials on the site and a possibility that features other than the housesite are intact. Less than $50 \%$ of the historic component appears intact; it may contain subsurface 
deposits and features. The historic component has an unknown research potential but is judged to be potentially eligible for listing on the NRHP according to Criterion D. It is recommended that the historic component be tested by hand excavation and the area accurately mapped. A records search and oral history interviews should be conducted to provide further information about the duration of occupation, the previous identity of the residential structure, and the locations and functions of various site components.

$\underline{41 G R 263}$

Location: Ca. $2.2 \mathrm{~km}$ NW of confluence of Double Mountain Fork and Little Grape Creek, and $2.0 \mathrm{~km}$ NE of confluence of Double Mountain Fork and Cat Hollow.

Description: Dugout homestead site on large ridge overlooking confluence of large unnamed side drainage east of Cat Hollow and smaller spring-fed creek; elevation 2250-2270 ft msl, area $48,000 \mathrm{~m}^{2}$. Ridge contains considerable prehistoric site with historic component located on bedrock bench below top of ridge. Prehistoric site first reported by Robert Campbell and recorded by GRC in 1982, who noted possible stone structures. Historic component consists of artifact scatter and remains of two structures. Area is near spring which is source of small creek. Temporal components are Historic and late Archaic-Late Prehistoric (see Appendix F for description of prehistoric component).

Features: Two structures; one is 3-m-long and 2-m-wide rectangular cluster of sandstone slabs, with few Potter chert nodules and one brick. Believed to be hearth area of old Roy dugout, although no discernible depression is near cluster. Second feature is rectangular area outlined by sandstone slabs with interior dimensions of $4 \times 4 \mathrm{ft}$. This feature may represent foundation of outhouse or other small outbullding.

Cultural Materials Observed/Collected: Stove front plate, wheel hub, 1932 Oklahoma license plate, single-strand barbed wire with looped single barbs, sanitary-type tin cans, tobacco tins, carbon battery rods, cut lumber fragments, wire nails, tin wheel cap with modern "Chevrolet" logo, and miscellaneous fragments of cast iron, pewter, whiteware, and bricks. Two items collected (see Appendices A and B).

Shovel Test Data: None.

S1te History: Site 41GR263 is located in Section 96, Block 5, a school tract of approximately 640 acres which the General Land Office leased to The Lexington Ranch Company of Nolan County between 1888 and 1896. The purpose of the lease was to obtain grazing lands (Garza County Deed Record 4:83-85, 280-282, 302-304; Deed Record 5:159-161).

According to Garza County resident Giles McCrary, The Lexington Ranch Company of Lexington, Kentucky, was headed by F. M. Smith; German B. Stout was the local manager. One employee was Rollie C. Burns, who wrote that he began to work for Stout in April 1883 herding cattle on Yellow House Creek (McCrary 1970:8). Three years later, the Company was paying taxes on all of Block 6 up the Double Mountain Fork and on 29 sections in Block 5, of which Section 96 was but one tract (Texas. Comptroller of Public Accounts 1886).

The cattle company leases on Section 96 appear to have lapsed, but interest in the area from companies such as the OS, owned first by Overall and Stout to the south near 
Fluvanna and then by A. J. and F. M. Long, remained strong. The Longs continued to operate in the area until 1901, when they sold out to a partnership consisting of W. E. Connell, John Scharbauer, and E. W. Clark (McCrary 1970:8; Garza County Deed Record 7:40-41).

Because settlers were beginning to move into the area south of the Double Mountain Fork in the 1890s, the cattle companies, which only held three-year leases on sections along the river, cast about for methods by which they could continue to control large blocks of land. The most common mechanism employed was for the ranch employees to file one section for a homestead and three adjoining or nearby sections for grazing purposes. The hands were then allowed to run their small herds in with their employers' larger herds, and the ranch owner effectively retained control over sections he had previously leased from the state.

One such employee was Walter Roy, who flled an affidavit with the General Land Office for Section 96, Block 5, on February 21, 1900. Listing his post office address as Dark, he swore that he was an actual settler on Section 96 and that he wanted to purchase the land. An affidavit filed three years later repeated his request and was witnessed by neighbors and fellow OS cowboys O. B. Kelly, W. G. Williams, and Carl Clark (Texas. General Land Office 1934).

Roy kept Section 96 until April 20, 1954, when he sold Sections 79, 80, 95, 96, and the east half of Section 106 in Block 5 to Novis N. Rodgers (Garza County Deed Record 63: 118). However, he probably lived at site 41GR263, which represented his original homestead claim, for a brief time. At an unknown date, he moved a short distance southwest to Section 95 (site 41GR565); the most recent Roy home is a National Register-eligible structure located outside of the project area in Section 118, Block 5.

Assessment/Recommendations: The historic component of site $41 \mathrm{GR} 263$ is comprised of the remains of a dugout occupled by Walter V. Roy, an OS cowboy who served on Garza County's first commissioners' court (The Post Dispatch, April 2, 1959:1). Over 75\% of the historic component appears intact; it contains features and may have subsurface deposits. The historic component has an excellent research potential and is judged to be potentially eligible for listing on the NRHP according to Criteria B and D because of its associations with a significant local figure and because it is one of several sites which represent the earliest known permanent Anglo-American occupation of the project area. In addition, it is representative of a specific, identifiable historical period in the development of the area, and the briefness of its occupation may provide important information about the material culture of the area at the turn of the century prior to the arrival of the railroad.

Testing by hand excavation is recommended for $41 \mathrm{GR} 263$ in order to ascertain information about the material culture of the project area at the turn of the century and the functions of the features at the site. Concurrent historical research should include compilation of oral histories from knowledgeable family members and local informants, use of the records at the Southwest Collections at Texas Tech University, Lubbock, and examination of the Roy family papers.

\section{$\underline{41 G R 273}$}

Location: Ca. $4.2 \mathrm{~km}$ WSW of intersection of Garza/Kent county line and Double Mountain Fork, and $2.4 \mathrm{~km}$ NW of confluence of Double Mountain Fork and Little Grape Creek. 
Description: Historic trash dump on canyon rim overlooking large unnamed side drainage east of Cat Hollow which flows south into Double Mountain Fork; elevation 2230-2250 ft msl, area $300 \mathrm{~m}^{2}$. Most of site is prehistoric component, but small historic artifact scatter is ca. $20 \times 15 \mathrm{~m}$. Area is deflated and eroded and has been bulldozed recently, so materials are not in situ. Small outbuilding may have been located here. Materials could be recent. Temporal components are Historic and undefined Prehistoric (see Appendix F for description of prehistoric component).

Features: None.

Cultural Materials Observed/Collected: Two brick fragments (labeled "Therm..." and "Elsta"), broken hacksaw blade, buried steel cable, pieces of cut lumber, and miscellaneous metal fragments. No collections made.

Shovel Test Data: None.

Site History: Site 41GR273 is located in Section 95, Block 5, a 640-acre grant surveyed on August 2, 1873, and patented to the Houston and Great Northern Railroad on December 27, 1873 (Texas. General Land Office 1873c). By November 1880, the land had been conveyed to the New York and Texas Land Company, Ltd. (Texas. General Land Office 1873b), and that company then leased a total of 137 surveys of 640 acres each in Blocks 4, 5, and 6, Garza and Kent counties, to the firm of J. W. Mooar Brothers. The firm, which was comprised of J. W. Mooar Brothers, Cornelius Brothers, and C. Sloan, agreed to pay $\$ 1753.60$ per year for five years (Garza County Deed Record 3:29-32).

On October 17, 1905, Walter Roy paid the Houston and Texas Central \$1600 for Section 95 (Garza County Deed Record 8:507-509) which was located immediately south of his homestead tract Section 96. He then constructed a frame house in the northwest quadrant of Section 95, possibly ca. 1921-1922 when the valuation of the section increased from $\$ 800$ to $\$ 2560$. Ownership of the section passed from Walter V. and Myrtle H. Roy on April 20, 1954 , when they sold it and three-and-one-half other sections to Novis N. Rodgers for $\$ 50,421.52$ (Garza County Deed Record 63:118).

Assessment/Recommendations: Site 41GR273 is located on Section 95, Block 5, which was the location of Walter and Myrtle Roy's second home. The site probably represents a disturbed dump or bulldozed outbuilding associated with the Roy home which was located west of 41GR273. Less than 50\% of the historic component appears intact; it may contain subsurface deposits. The historic component has a low research potential and is judged to be not eligible for listing on the NRHP. No further work is recommended for this site.

\section{GR283}

Location: Ca. $2.7 \mathrm{~km}$ NNE of confluence of Double Mountain Fork and Rocky Creek, and $3.1 \mathrm{~km}$ WNW of confluence of Double Mountain Fork and Little Grape Creek.

Description: Rock art site on rock face on lower valley wall of small drainage flowing south into Double Mountain Fork; elevation $2250 \mathrm{ft} \mathrm{msl}$, area less than $1 \mathrm{~m}^{2}$. Single undated inscription believed to be historic due to style of lettering, which is similar to inscriptions dating to late 1800 s and early 1900s. Temporal component is Historic. 
Features: Set of initials with three tally marks; overall size $44 \mathrm{~cm}$ long and $36 \mathrm{~cm}$ tall. Initials are "J T B" and cover area $44 \mathrm{~cm}$ long and $22 \mathrm{~cm}$ high. Below "T" are three diagonal parallel lines ca. $8 \mathrm{~cm}$ long and $3 \mathrm{~cm}$ apart. For further information about inscriptions, see Appendix E.

Cultural Materials Observed/Collected: None.

Shovel Test Data: None.

Assessment/Recommendations: Over $90 \%$ of this site appears intact; it lacks associated subsurface deposits. The site has research potential and is judged to be potentially eligible for listing on the NRHP. However, initial field recording has exhausted the site's potential at this time, and no further work is recommended.

\section{GR284}

Location: Ca. $2.7 \mathrm{~km}$ NNE of confluence of Double Mountain Fork and Rocky Creek, and $3.0 \mathrm{~km}$ WNW of confluence of Double Mountain Fork and Little Grape Creek.

Description: Rock art site on vertical face on bluff overlooking Double Mountain Fork; elevation $2240 \mathrm{ft} \mathrm{msl}$, area $0.525 \mathrm{~m}^{2}$. Date and set of initials carved into rock face. Temporal component is Historic.

Features: Historic inscription consisting of date and set of initials. Inscription is ca. $150 \mathrm{~cm}$ long and $35 \mathrm{~cm}$ tall and reads "JULY $111914 \mathrm{E}-\mathrm{V}-\mathrm{B}-$." Tail of "Y" is drawn to underline word "JULY." For further information about inscription, see Appendix E.

Cultural Materials Observed/Collected: None.

Shovel Test Data: None.

Assessment/Recommendations: Over $90 \%$ of this site appears intact; it lacks associated subsurface deposits. The site has research potential and is judged to be potentially eligible for listing on the NRHP. However, initial field recording has exhausted the site's potential at this time, and no further work is recommended.

\section{GR285}

Location: Ca. $2.7 \mathrm{~km}$ NNE of confluence of Double Mountain Fork and Rocky Creek, and $3.0 \mathrm{~km}$ WNW of confluence of Double Mountain Fork and Little Grape Creek.

Description: Rock art site on vertical rock face on bluff overlooking Double Mountain Fork; elevation $2220 \mathrm{ft} \mathrm{msl}$, area less than $1 \mathrm{~m}^{2}$. Historic inscription including date and name. Temporal component is Historic.

Features: Historic inscription ca. $85 \mathrm{~cm}$ long and $25 \mathrm{~cm}$ tall, reading "JAN 31915 MYRTL." First letter of name is drawn as either script or lower case "m." For further information about inscription, see Appendix $\mathrm{E}$. 
Cultural Materials Observed/Collected: None.

Shovel Test Data: None.

Assessment/Recommendations: Over $90 \%$ of this site appears intact; it lacks associated subsurface deposits. The site has research potential and is judged to be potentially eligible for listing on the NRHP. However, initial field recording has exhausted the site's potential. at this time, and no further work is recommended.

\section{GR287}

Location: Ca. $2.8 \mathrm{~km}$ NNE of confluence of Double Mountain Fork and Rocky Creek, and $3.0 \mathrm{~km}$ WNW of confluence of Double Mountain Fork and Little Grape Creek.

Description: Trash dump on eroded bench on upland margin near canyon rim of Double Mountain Fork; elevation 2280-2290 ft msl, area $490 \mathrm{~m}^{2}$. Prehistoric site with historic component represented by small (ca. $25 \mathrm{~m}$ diameter) scatter of historic trash. No evidence of structure. Materials appear to be relatively recent but could be as old as 1920 . Temporal components are Historic and undefined Prehistoric (see Appendix F for description of prehistoric component).

Features: None.

Cultural Materials Observed/Collected: Hole-in-top tin cans, large 1-gallon sanitarytype tin cans, rectangular cans with pour spouts, and brass center-fire cartridge case. No collections made.

Shovel Test Data: None.

Site History: Site 41GR287 is located in Section 106, Block 5, a school tract on which The Lexington Ranch Company paid taxes as early as 1886 (Texas. Comptroller of Public Accounts 1886) and which they leased from the General Land office for grazing between 1890 and 1896 (Garza County Deed Record 4:280-282, 302-304; Deed Record 5:159-161).

Presumably after The Lexington Ranch Company's lease expired, A. J. and F. M. Long, who had bought the Overall and Street cattle, leased 20 sections, including Section 106. They then subleased the land to Connell, Clark, and Scharbauer (Garza County Deed Record $\underline{6}: 301-338)$.

On February 21, 1900, Walter Roy, who was living on Section 96, Block 5 (site 41GR263), applied to purchase Section 106 which was classified as dry grazing. He made payments on the property until the mid 1930s, when he received a patent to the land (Texas. General Land Office 1935). However, he did not live on the tract at any time, his second home being located on Section 95, Block 5 (see Site History, 41GR273).

Assessment/Recommendations: Because the Roy family is not known to have occupied any part of Section 106, Block 5, on which site 41GR287 is located, it is assumed that the site, 1ike 41GR288, 41GR289, 41GR290, and 41GR292, represents modern dumping episodes. Over $75 \%$ of the historic component appears intact; it lacks subsurface deposits. The 
historic component has a low research potential and is judged to be not eligible for listing on the NRHP. No further work is recommended.

\section{GR288}

Location: Ca. $2.8 \mathrm{~km}$ NNE of confluence of Double Mountain Fork and Rocky Creek, and $3.0 \mathrm{~km}$ WNW of confluence of Double Mountain Fork and Little Grape Creek.

Description: Trash dump at head of small erosional gully in upland margin on canyon rim of Double Mountain Fork; elevation $2280 \mathrm{ft} \mathrm{msl}$, area $10 \mathrm{~m}^{2}$. Scatter of historic trash measuring ca. 5x2-m. Apparently dump used several times from 1930s to 1950s. Temporal component is Historic.

Features: None.

Cultural Materials Observed/Collected: Oval tobacco cans, 1-gallon cans, 1-quart oil can, two large dry-cell batteries, Vaseline jar, clear glass panel bottle (Gebhardt's), clear glass panel bottle with cork top, cylindrical medicine bottle, snuff bottle, and two lumps of tar or rubber. No collections made.

Shovel Test Data: None.

Site History: History of site $41 \mathrm{GR} 288$ is identical to $41 \mathrm{GR} 287$.

Assessment/Recommendations: Over $90 \%$ of this site appears intact; it lacks subsurface deposits. The site has a low research potential and is judged to be not eligible for listing on the NRHP. No further work is recommended.

\section{$\underline{41 G R 289}$}

Location: Ca. $2.7 \mathrm{~km}$ NNE of confluence of Double Mountain Fork and Rocky Creek, and $3.2 \mathrm{~km}$ WNW of confluence of Double Mountain Fork and Little Grape Creek.

Description: Trash dump site in crevice between two rocks in upland margin on canyon rim of Double Mountain Fork; elevation $2260 \mathrm{ft} \mathrm{msl}$, area $4 \mathrm{~m}^{2}$. Crevice within erosional gully contains small $(2 \times 2 \mathrm{~m})$ scatter of historic trash which appears to date to first half of twentieth century. Site may be related to 41GR290, another trash dump ca. $70 \mathrm{~m}$ to northwest. Temporal component is Historic.

Features: None.

Cultural Materials Observed/Collected: Manganese-bleached glass bottle, coal or fireplace scoop, oval tobacco cans, hole-in-top cans with solder drop on top, sanitary-type tin cans, and square tin cans. No collections made.

Shovel Test Data: None. 
Site History: History of site 41GR289 is identical to sites 41GR287 and 41 GR288.

Assessment/Recommendations: Over $90 \%$ of the site appears intact; it lacks subsurface deposits. The site has a low research potential and is judged to be not eligible for listing on the NRHP. No further work is recommended.

\section{$\underline{41 G R 290}$}

Location: Ca. $2.7 \mathrm{~km}$ NNE of confluence of Double Mountain Fork and Rocky Creek, and $3.2 \mathrm{~km}$ WNW of confluence of Double Mountain Fork and Little Grape Creek.

Description: Trash dump along canyon rim of Double Mountain Fork in upland margin; elevation $2260 \mathrm{ft} \mathrm{msl}$, area $400 \mathrm{~m}^{2}$. Ca. 20-m-diameter scatter of historic trash which seems to date from 1930 s to 1950 s and apparently is result of several dumping episodes. No structural remains. Temporal component is Historic.

Features: None.

Cultural Materials Observed/Collected: Window glass fragments, oval tobacco tins, fragments of whiteware, barrel band, two clear glass bottles (including one medicine bottle), light bulb base, and miscellaneous glass fragments. No collections made.

Shovel Test Data: None.

Site History: History of site 41GR290 is identical to 41GR287, 41GR288, and 41 GR289.

Assessment/Recommendations: Over $90 \%$ of the site appears intact; it lacks subsurface deposits. The site has a low research potential and is judged to be not eligible for listing on the NRHP. No further work is recommended.

\section{$\underline{41 G R 292}$}

Location: Ca. $5.3 \mathrm{~km}$ SW of Intersection of Garza/Kent county line and Double Mountain Fork, and $2.5 \mathrm{~km}$ W of confluence of Double Mountain Fork and Little Grape Creek.

Description: Isolated find of single bottle on upland margin near canyon rim of Double Mountain Fork; elevation $2230 \mathrm{ft} \mathrm{msl}$, area less than $1 \mathrm{~m}^{2}$. Temporal component is Historic.

Features: None.

Cultural Materials Observed/Collected: Clear glass panel bottle with neck missing, patinated, with Hazel Atlas manufacturer's mark and patent date of "June 22 1909" molded into base. No collections made.

Shovel Test Data: None. 
Site History: History of site 41GR292 is identical to 41GR287, 41GR288, 41GR289, and 41GR290.

Assessment/Recommendations: Over $90 \%$ of the site appears intact; it lacks subsurface deposits. The site has a low research potential and is judged to be not eligible for listing on the NRHP. No further work is recommended.

$\underline{41 G R 294}$

Location: Ca. $0.3 \mathrm{~km} \mathrm{NW}$ of confluence of Double Mountain Fork and Cat Hollow, and 2.3 $\mathrm{km}$ NNE of confluence of Double Mountain Fork and Rocky Creek.

Description: Rock art site on vertical sandstone face on bluff overlooking Cat Hollow; elevation $2230 \mathrm{ft} \mathrm{msl}$, area less than $1 \mathrm{~m}^{2}$. Single historic inscription. Temporal component is Historic.

Features: Historic inscription $85 \mathrm{~cm}$ long and $10 \mathrm{~cm}$ tall, reading "WILL W. MAY 27 '04." Year probably is 1904. For further information about inscription, see Appendix E.

Cultural Materials Observed/Collected: None.

Shovel Test Data: None.

Assessment/Recommendations: Over $90 \%$ of the site appears intact; it lacks associated subsurface deposits. The site has research potential and is judged to be potentially eligible for listing on the NRHP. However, initial field recording has exhausted the site's potential at this time, and no further work is recommended.

\section{GR295}

Location: Ca. $0.2 \mathrm{~km} \mathrm{NW}$ of confluence of Double Mountain Fork and Cat Hollow, and 2.2 $\mathrm{km}$ NNE of confluence of Double Mountain Fork and Rocky Creek.

Description: Rock art site on vertical sandstone face on bluff slope overlooking Cat Hollow; elevation $2240 \mathrm{ft} \mathrm{msl}$, area $42 \mathrm{~m}^{2}$. Large panel of probable historic graffiti. Inscriptions may be relatively recent judging from minimal weathering and style of lines. Temporal component is Historic.

Features: Five elements or inscriptions in area ca. $7 \mathrm{~m} \mathrm{long}$ and $6 \mathrm{~m} \mathrm{tall.} \mathrm{First} \mathrm{is}$ single line $6 \mathrm{~cm}$ long. Second is panel including inscriptions: "SP," " $t$," and "H." Third reads "P LL," with "Ls" formed by two horizontal parallel lines intersected by two vertical parallel lines. Fourth reads "BR..GE," and fifth reads "JONNY." For further information on inscriptions, see Appendix E.

Cultural Materials Observed/Collected: None.

Shovel Test Data: None. 
Assessment/Recommendations: Over $90 \%$ of the site appears intact; it lacks associated subsurface deposits. The site has research potential and is judged to be potentially eligible for listing on the NRHP. However, initial field recording has exhausted the site's potential at this time, and no further work is recommended.

\section{$\underline{41 G R 298}$}

Location: Ca. $0.6 \mathrm{~km}$ WSW of confluence of Double Mountain Fork and Cat Hollow, and $1.9 \mathrm{~km}$ NNW of confluence of Double Mountain Fork and Rocky Creek.

Description: Rock art site on exposed sandstone face at base of bluff overlooking side canyon of Double Mountain Fork; elevation $2195 \mathrm{ft} \mathrm{msl}$, area less than $1 \mathrm{~m}^{2}$. Two sets of initials and heart carved into rock face. Style of lettering is similar to that of inscriptions dating to late nineteenth and early twentieth centuries. Temporal component is Historic.

Features: Historic inscription ca. $80 \mathrm{~cm}$ long and $40 \mathrm{~cm}$ tall includes two sets of initials with heart drawn to left. Initials are "ECW," with "LEJ" written below. For further information about inscriptions, see Appendix E.

Cultural Materials Observed/Collected: None.

Shovel Test Data: None.

Assessment/Recommendations: Over $90 \%$ of the site appears intact; it lacks associated subsurface deposits. The site has research potential and is judged to be potentially eligible for listing on the NRHP. However, initial field recording has exhausted the site's potential at this time, and no further work is recommended.

\section{GR304}

Location: Ca. $0.7 \mathrm{~km}$ WSW of confluence of Double Mountain Fork and Cat Hollow, and $2.0 \mathrm{~km}$ NNE of confluence of Double Mountain Fork and Rocky Creek.

Description: Trash dump from bottom of canyon to upper rim on upland margin of Double Mountain Fork; elevation 2270-2300 ft msl, area $1962 \mathrm{~m}^{2}$. Scatter of historic debris, including large concentration of tin cans on upper rim of canyon. No indication of habitation in area. Probably result of several dumping episodes; could date to ca. 1939. Temporal component is Historic.

\section{Features: None.}

Cultural Materials Observed/Collected: Solder-dot tin cans, snuff cans, graphite battery rods, skillet, wire fragments, 1939 Texas license plate, clear glass bottles, crockery fragments, and single burned Potter chert cobble. The cobble was probably burned along with the trash and does not constitute a prehistoric component. No collections made. 
Shovel Test Data: None.

Site History: The history of the property on which 41GR304 is located is identical to that of site 41GR287 until the mid 1920s, at which time S. S. Bevers purchased the west half of the section from Walter V. Roy. The Bevers home presently is located on the north half of the west half of Section 106, Block 4, and it is possible that sites 41GR304, 41GR370, and 41GR375 represent dumps associated with that residence. A son recalled no habitation site on the Bevers land in the vicinity of Cedar Hill or Cat Hollow and noted that until his parents moved to the northwest quarter of Section 106, they lived in a house at a windmill south of the third Walter Roy home in Section 118 (Bevers 1987).

Assessment/Recommendations: Site 41GR304 apparently represents a dump associated with the habitation of the S. S. Bevers family in the northwest quarter of Section 106. Less than $50 \%$ of the site appears intact; it may lack subsurface deposits. The site has a low research potential and is judged to be not eligible for listing on the NRHP. No further work is recommended.

\section{GR305}

Location: Ca. $0.8 \mathrm{~km}$ WSW of confluence of Double Mountain Fork and Cat Hollow, and $1.8 \mathrm{~km}$ NNE of confluence of Double Mountain Fork and Rocky Creek.

Description: Rock art site on vertical sandstone face on eroded valley slopes above head of small drainage flowing into Double Mountain Fork; elevation $2230 \mathrm{ft}$ msl, area less than $1 \mathrm{~m}^{2}$. Three inscriptions, two with dates. Temporal component is Historic.

Features: Three inscriptions, each separated by ca. $1 \mathrm{~m}$. First inscription is ca. 32 $\mathrm{cm}$ long and $10 \mathrm{~cm}$ tall and reads "86RKK." It is assumed that "86" refers to 1886. Second inscription $\mathrm{ca} .50 \mathrm{~cm}$ long and $15 \mathrm{~cm}$ tall includes two sets of dated Initials. First set reads "WS" over "19B36." Other set reads "DKC 1888" and is Ca. $10 \mathrm{~cm}$ to right of first set. Date on this inscription is eroded. Third inscription is $1 \mathrm{~m}$ farther to right of second inscription and appears to read "11DB," but could read "HDB." For further information about inscriptions, see Appendix E.

\section{Cultural Materials Observed/Collected: None.}

Shovel Test Data: None.

Assessment/Recommendations: Over $90 \%$ of the site appears intact; it lacks associated subsurface deposits. The site has research potential and is judged to be potentially eligible for listing on the NRHP. However, initial field recording has exhausted the site's potential at this time, and no further work is recommended.

\section{$41 \mathrm{GR} 307$}

Location: Ca. $0.8 \mathrm{~km}$ WSW of confluence of the Double Mountain Fork and Cat Hollow, and $1.8 \mathrm{~km}$ NNE of confluence of Double Mountain Fork and Rocky Creek. 
Description: Rock art site on vertical rock face at head of small drainage near base of bluff above Double Mountain Fork; elevation $2190 \mathrm{ft} \mathrm{msl}$, area less than $1 \mathrm{~m}^{2}$. Single inscription. Temporal component is Historic.

Features: Inscription $45 \mathrm{~cm}$ long and $25 \mathrm{~cm}$ tall, reading "E.M.W. MAR. 26. 34." Year indicated probably is 1934. For further information on inscription, see Appendix E.

Cultural Materials Observed/Collected: None.

Shovel Test Data: None.

Assessment/Recommendations: Over 90\% of the site appears intact; 1 t lacks associated subsurface deposits. The site has research potential and is judged to be potentially eligible for listing on the NRHP. However, initial field recording has exhausted the site's potential at this time, and no further work is recommended.

\section{$\underline{41 G R 308}$}

Location: Ca. $0.8 \mathrm{~km}$ WSW of confluence of Double Mountain Fork and Cat Hollow, and $1.7 \mathrm{~km}$ NNE of confluence of Double Mountain Fork and Rocky Creek.

Description: Rock art site on exposed sandstone face on bluff below erosional remnant mesa above Double Mountain Fork; elevation $2260 \mathrm{ft} \mathrm{msl}$, area $1.26 \mathrm{~m}^{2}$. Panel of historic inscriptions containing numerous names and sets of initials but no clear dates. One name is written in style typical of late nineteenth or early twentieth century. Temporal component is Historic.

Features: Single large panel of inscriptions ca. $105 \mathrm{~cm}$ long and $120 \mathrm{~cm}$ tall. One inscription is illegible, but others read (top to bottom) "DEE," "WVR," "WG. WILLIAMS" (with last seven letters written ca. one-third size of others), "S.DB," "WIIIW," and "DEC 01 1 50." Apparently older inscription is ca. $45 \mathrm{~cm}$ long and $30 \mathrm{~cm}$ tall and reads "OBADEN 87"; "7" is reversed and an arrow drawn over top of name points to right and is $30 \mathrm{~cm} l o n g$ and $10 \mathrm{~cm}$ tall. Number and upside-down "L" below name. "WILLIAMS" inscription probably is local landowner or relative. For further information about inscriptions, see Appendix E.

Cultural Materials Observed/Collected: None.

Shovel Test Data: None.

Assessment/Recommendations: Over $90 \%$ of the site appears intact; it lacks associated subsurface deposits. The site has research potential and is judged to be potentially eligible for listing on the NRHP. However, initial field recording has exhausted the site's potential at this time, and no further work is recommended.

\section{$\underline{41 G R 313}$}

Location: Ca. $1.2 \mathrm{~km} \mathrm{~N}$ of confluence of Double Mountain Fork and Rocky Creek, and 4.5 $\mathrm{km}$ WSW of confluence of Double Mountain Fork and Little Grape Creek. 
Description: Rock art site on bluff of erosional remnant mesa overlooking Gobbler Creek; elevation $2220 \mathrm{ft} \mathrm{msl}$, area less than $1 \mathrm{~m}^{2}$. Two historic inscriptions. Temporal component is Historic.

Features: Panel ca. $35 \mathrm{~cm}$ long and $14 \mathrm{~cm}$ tall contains two dated inscriptions on vertical rock face ca. 2 m above slope. One reads "1934 WSB," and other reads "R.J 1937." For further information about inscriptions, see Appendix E.

Cultural Materials Observed/Collected: None.

Shovel Test Data: None.

Assessment/Recommendations: Over 90\% of the site appears intact; it lacks associated subsurface deposits. The site has research potential and is judged to be potentially eligible for listing on the NRHP. However, initial field recording has exhausted the site's potential at this time, and no further work is recommended.

\section{$\underline{41 G R 315}$}

Location: Ca. $1.2 \mathrm{~km} \mathrm{~N}$ of confluence of Double Mountain Fork and Rocky Creek, and 4.5 km WSW of confluence of Double Mountain Fork and Little Grape Creek.

Description: Rock art site in overhang shelter on mesa bluff slope overlooking Gobbler Creek; elevation $2220 \mathrm{ft} \mathrm{msl}$, area $14 \mathrm{~m}^{2}$. Shelter is ca. $6.4 \mathrm{~m}$ long and ca. $3.5 \mathrm{~m}$ deep; floor has thin deposit of sand without evidence of occupation. Several panels of rock art on back wall of shelter include both prehistoric petroglyphs and historic inscriptions. More historic elements than prehistoric; total of 10 inscriptions, 5 with dates ranging from 1841(?) to 1974, with 2 dates over 50 years old. Temporal components are Historic and undefined Prehistoric (see Appendix F for description of prehistoric component).

Features: Two inscriptions with historic dates and two which appear to be historic based on style of lettering. First is $14 \mathrm{~cm}$ long and $6 \mathrm{~cm}$ tall and reads "LINCOLN 1841" (probably a bogus inscription). Second is $80 \mathrm{~cm}$ long and $16 \mathrm{~cm}$ tall and reads "BANDY. CASH SEPT. 9. 1935." Third is $37 \mathrm{~cm}$ long and $14 \mathrm{~cm}$ tall and reads "MELVIN McCALLOM." Fourth inscription, "WW," may relate to Williams family who were present in project area by 1900 . Rest of inscriptions have no dates or are dated 1958 or later. The name "NORM CASH" is also inscribed without a date. Norm Cash was born in Justiceburg in 1936 and played professional baseball with the Detroit Tigers. For further information about inscriptions, see Appendix E.

Cultural Materials Observed/Collected: None.

Shove]. Test Data: None.

Assessment/Recommendations: Over $90 \%$ of the historic inscriptions are intact; they lack associated subsurface deposits. The historic inscriptions have research potential and are judged to be potentially eligible for listing on the NRHP. However, initial field recording has exhausted the site's potential at this time, and no further work is recommended. 
Location: Ca. $1.3 \mathrm{~km} \mathrm{~N}$ of confluence of Double Mountain Fork and Rocky Creek, and 4.6 km WSW of confluence of Double Mountain Fork and Little Grape Creek.

Description: Rock art site on vertical rock face on bluff slope of mesa overlooking Gobbler Creek; elevation $2220 \mathrm{ft} \mathrm{msl}$, area $12 \mathrm{~m}^{2}$. Several panels of aboriginal and historic rock art. Most inscriptions appear to be recent, and one has 1965 date. However, four may be historic because of lettering style. Temporal components are Historic and undefined Prehistoric (see Appendix F for description of prehistoric component).

Features: Four inscriptions may be historic. One is ca. $20 \mathrm{~cm}$ long and $7 \mathrm{~cm}$ tall and reads "EEW." Another is $15 \mathrm{~cm}$ long and $11 \mathrm{~cm}$ tall and reads "R. J." Third is $13 \mathrm{~cm}$ long and $8 \mathrm{~cm}$ tall and reads "BU." Fourth is ca. $9 \mathrm{~cm}$ long and $6 \mathrm{~cm}$ tall and reads "S.B." Other inscriptions are shallow and eroded. For further information about inscriptions, see Appendix E.

Cultural Materials Observed/Collected: None.

Shovel Test Data: None.

Assessment/Recommendations: Over $90 \%$ of the historic inscriptions appear intact; they lack associated subsurface deposits. The historic inscriptions have research potential and are judged to be potentially eligible for listing on the NRHP. However, initial field recording has exhausted the site's potential at this time, and no further work is recommended.

\section{$\underline{41 G R 321}$}

Location: Ca. $1.0 \mathrm{~km} \mathrm{~N}$ of confluence of Double Mountain Fork and Rocky Creek, and 4.5 $\mathrm{km}$ WSW of confluence of Double Mountain Fork and Little Grape Creek.

Description: Rock art site in rock overhang on bluff face below small point overlooking Gobbler Creek; elevation $2260 \mathrm{ft} \mathrm{msl}$, area $1.6 \mathrm{~m}^{2}$. Two historic inscriptions carved into rock face below overhang. One has 1932 date. Temporal component is Historic.

Features: Two inscriptions $3 \mathrm{~m}$ apart. First is $20 \mathrm{~cm}$ long and $18 \mathrm{~cm}$ tall and reads "ETHEL 1932." Second is $5 \mathrm{~cm}$ long and $10 \mathrm{~cm}$ tall and reads "R.J." For further information about inscriptions, see Appendix E.

Cultural Materials Observed/Collected: None.

Shovel Test Data: None.

Assessment/Recommendations: Over $90 \%$ of the site appears intact; it lacks associated subsurface deposits. The site has research potential and is judged to be potentially eligible for listing on the NRHP. However, initial field recording has exhausted the site's potential at this time, and no further work is recommended. 
Location: Ca. $1.1 \mathrm{~km}$ NNE of confluence of Double Mountain Fork and Rocky Creek, and $4.3 \mathrm{~km}$ WSW of confluence of Double Mountain Fork and Little Grape Creek.

Description: Rock art site on rock face on bluff slopes below eroded upland point overlooking Gobbler Creek; elevation $2230 \mathrm{ft} \mathrm{msl,} \mathrm{area} 1.6 \mathrm{~m}^{2}$. Two inscriptions, one with historic date, in small wind-eroded hole in sandstone bluff face cover ca. 8-m-long and 20-cm-high area. Temporal component is Historic.

Features: Two inscriptions ca. $8 \mathrm{~m}$ apart. First is $25 \mathrm{~cm}$ long and $14 \mathrm{~cm}$ tall and reads "DCD 1940." Second is somewhat larger and reads "ED. SCOTT Mr 1887." For further information about inscriptions, see Appendix E.

Cultural Materials Observed/Collected: None.

Shovel Test Data: None.

Assessment/Recommendations: Over $90 \%$ of the site appears intact; it lacks associated subsurface deposits. The site has research potential and is judged to be potentially eligible for listing on the NRHP. However, initial field recording has exhausted the site's potential at this time, and no further work is recommended.

\subsection{GR331}

Location: Ca. $0.8 \mathrm{~km} \mathrm{NE}$ of intersection of U.S. Highway 84 and FM 2458 , and $1.5 \mathrm{~km}$ NNE of U.S. Highway 84 bridge over Double Mountain Fork.

Description: Unidentified historic site on upland plateau overlooking Salt Branch; elevation $2250 \mathrm{ft} \mathrm{msl}$, area $125,000 \mathrm{~m}^{2}$. Extensive prehistoric artifact scatter, with two areas of historic artifacts ca. $395 \mathrm{ft}$ apart. One area measures ca. $330 \times 230 \mathrm{ft}$, while other is ca. $395 \times 165 \mathrm{ft}$. Larger area appears to be small trash dump concentrated in area ca. $54 \mathrm{ft}$ in diameter. Other area contains historic artifact scatter and feature consisting of two concrete supports with rebar extending out of them. Cultural materials are concentrated in area $\mathrm{Ca} .30 \mathrm{ft}$ in diameter and could represent remains of historic structure. Site area somewhat disturbed by stock tank and dirt road which runs along edge of site and clearing of some areas. Temporal components are Historic and undefined Prehistoric (see Appendix $F$ for description of prehistoric component).

Features: Two concrete supports, ca. $8 \mathrm{ft}$ apart and ca. $10 \mathrm{ft}$ long, 20 inches wide, and 30 inches tall. Reinforced with metal, which sticks out of top; aggregate is large cobbles of Potter chert. Could be remains of foundation or channeling structure related to nearby stock tank.

Cultural Materials Observed/Collected: Fragments of whiteware, manganese-bleached glass fragments, bottle glass fragments, window glass fragments, crockery fragments, stove parts, washtub, seat springs, metal pots, tin cans, metal fragments, and pieces of cut wood. Three items collected (see Appendix A). 
Shovel Test Data: One shovel test in area of possible housesite yielded glass fragments (clear and brown) at 0-20 cm below surface and indicated soil depth of ca. $20 \mathrm{~cm}$.

Site History: Site 41GR331 is located in Section 24, Block 6, a school tract which The Lexington Ranch Company of Nolan County leased for grazing from the General Land Office from January 31, 1888, to ca. 1893 (Garza County Deed Record 4:83-85, 280-282, 302-304). The grazing lease appears to have lapsed until February 17, 1900, when T. J. Payne made an application to the State to purchase the Section for $\$ 1.50$ per acre. His residence was located on Section 26, Block 6, and he wished to use Section 24 for grazing purposes (Texas. General Land Office 1919a).

On February 25, 1903, J. T. [sic] Payne sold Sections 24, 26, 36, and the west half of Section 30, Block 6, and a one-third interest in approximately 250 head of cattle branded $\mathrm{JH}$ and ear-marked $O \mathrm{O}$ to his son T. E. Payne, who had settled near present-day Justiceburg in December 1899 (Garza County Deed Record 7:266-267; Texas. General Land Office 1936). T. E. and Rowena Payne owned the property until October 6, 1905, when they sold an undivided one-half interest in Sections $24,26,31,32,36,37,38,40,44$, and 45 , and a one-half interest in the west half of Section 30 to John W. Person, their son-in-law. Four years later, Payne sold the remaining one-half interest in Section 24, on which 41GR331 is located, to J. W. Person (Garza County Deed Record 9:396-397; Deed Record 10: 408).

Person, representative for the Brazos Valley Townsite Corporation, purchased Section 24 with the idea of developing a town adjacent to the newly constructed Gulf, Colorado \& Santa Fe Railway right-of-way. In February 1910, Person and L. E. Lasseter, who were co-owners of the Section, hired H. W. Stoneham, surveyor for Mitchell County, Texas, to survey out a townsite which they called Burnham. The completed plat was signed on March 5, 1910, and filed in the Garza County records on May 11 (Garza County Map and Plat Record No. $1: 15)$.

Judging from the Garza County deed records, Person was moderately successful at selling lots in Burnham, and by January 1911, the town was sufficiently well populated to support a mercantile company which was run by Nicholas J. Lanotte, a former resident of Irving who went into partnership with his brother-in-law, John Fumigalli (Garza County Deed Record 13:163-164; Women's Division of Post Chamber of Commerce n.d.:92). However, Burnham appears to have been overshadowed by Justiceburg, an adjoining town platted in 1910 and filed with the Garza County Clerk on August 9 (Garza County Map and Plat Record №. 1:14). Eventually, Section 24 reverted to pasture land.

Assessment/Recommendations: A comparison of the Justiceburg 7.5' quadrangle with Stoneham's townsite survey suggests that site $41 \mathrm{GR} 331$ is located on what formerly was Block 55 in Burnham. Artifacts and features present at the site suggest that it may have been the location of a building during or soon after the time Burnham was platted and lots were sold.

Insufficient research has been completed to identify the age, occupants, or use of 41GR331. Over 50\% of the historic component appears intact; it contains subsurface deposits. The historic component has an unknown research potential but is judged to be potentially eligible for listing on the NRHP according to Criteria A and D. Because of the significance of Burnham as an early platted town in Garza County, it is recommended that sufficient legal, archival, and oral history work be done to positively identify the site and to suggest the extent of archeological testing and/or excavation. 
Location: Ca. $6.9 \mathrm{~km}$ ESE of intersection of U.S. Highway 84 and FM 2458, and $4.1 \mathrm{~km}$ NE of U.S. Highway 84 bridge over Sand Creek.

Description: Rock art site in pinnacle of eroded sandstone separated from main body of the bluff, overlooking Double Mountain Fork; elevation $2250 \mathrm{ft} \mathrm{msl}$, area $100 \mathrm{~m}^{2}$. Two "blow holes" through pinnacle contain large number of historic inscriptions, prehistoric petroglyphs, and recent graffiti. Only small fraction of historic inscriptions still legible; erosion and overlapping inscriptions have obliterated them. Temporal components are Historic and undefined Prehistoric (see Appendix F for description of prehistoric component).

Features: Four historic inscriptions with dates still readable. First (oldest) measures $72 \mathrm{~cm}$ long and $23 \mathrm{~cm}$ tall and reads "JUNE 6. $1849 \mathrm{U}$. S. R" with "N" written backwards; area after " $R$ " obliterated by erosion and graffiti. Above word "JUNE" is second, smaller inscription, "11. 25. 1934." Third inscription is $33 \mathrm{~cm}$ long and $4 \mathrm{~cm}$ tall and reads "JAN-2-13." Fourth is ca. $70 \mathrm{~cm}$ long and $20 \mathrm{~cm}$ tall and reads "A. Y. JENNINGS AUG. 26. 1923"; "N"s are written backwards, and "...ENNINGS" is written ca. one-half size of initials. For further information about inscriptions, see Appendix E.

Cultural Materials Observed/Collected: None.

Shovel Test Data: None.

Assessment/Recommendations: Over $75 \%$ of historic inscriptions appear intact; they lack associated subsurface deposits. The historic inscriptions have research potential and are judged to be potentially eligible for listing on NRHP. Due to the possible age of the earliest inscription, it is recommended that the site be more fully documented with photographs and detailed drawings.

\section{$\underline{41 G R 350}$}

Location: Ca. $4.2 \mathrm{~km}$ WSW of intersection of Garza/Kent county line and Double Mountain Fork, and $2.2 \mathrm{~km} \mathrm{NW}$ of confluence of Double Mountain Fork and Little Grape Creek.

Description: Trash dump on eroding upland ridge overlooking unnamed drainage east of Cat Hollow; elevation 2200-2280 ft msl, area 45,000 $\mathrm{m}^{2}$. Large prehistoric site with historic component consisting of scatter of historic trash and debris concentrated in two areas. Concentrations are in areas where bedrock is exposed, and apparently materials were deposited after erosion had taken place. No evidence of a structure, so area was used as trash dump for historic residence elsewhere in vicinity. Temporal components are Historic and undefined Prehistoric (see Appendix F for description of prehistoric component).

Features: None.

Cultural Materials Observed/Collected: Texas license plate reading "1-160 459 Texas 1929" (five-pointed star separates numbers), tin cans, bottles, whiteware fragments, 
crockery fragments, hole-in-top cans, stove leg, clear glass bottle base with 1915 date, milk glass, pieces of lumber with round nails, brick fragments, and miscellaneous metal fragments. One item collected (see Appendices $A$ and B).

Shovel Test Data: None.

Site History: Identical to history of 41GR273.

Assessment/Recommendations: Site 41 GR350 appears to be a dump which is associated with the second Walter V. Roy house in the northwest quadrant of Section 95. Over 75\% of the historic component appears intact; it lacks subsurface deposits. The historic component has an excellent research potential and is judged to be potentially eligible for listing on the NRHP. Because the duration of occupation at the Roy Housesite is limited and isolable, it is recommended that collections be made and the artifacts compared with those present at 41GR263, the first Walter V. Roy homestead site.

\section{$\underline{4 \mathrm{GR} 370}$}

Location: Ca. $0.7 \mathrm{~km}$ NW of confluence of Double Mountain Fork and Cat Hollow, and 2.5 $\mathrm{km}$ NNE of confluence of Double Mountain Fork and Rocky Creek.

Description: Trash dump on eroding upland margin overlooking Cat Hollow near head of drainage; elevation $2285 \mathrm{ft} \mathrm{msl}$, area $706.5 \mathrm{~m}^{2}$. Small scatter of historic debris ca. $30 \mathrm{~m}$ in diameter. Road ca. $70 \mathrm{~m}$ north of site probably not related to dump. Materials appear to date to 1940 s or 1950 s. Temporal component is Historic.

Features: None.

Cultural Materials Observed/Collected: Modern sanitary tin cans, crockery fragments, enamelware, large tin buckets, automobile battery casings, rubber boot sole, oval wine bottle labeled "Ball," screw-top rectangular panel glass bottle, and old brown glass bleach bottle (Clorox). No collections made.

Shovel Test Data: None.

Site History: Identical to history of $41 \mathrm{GR} 304$.

Assessement/Recommendations: Site 41GR370 apparently represents a dump associated with the habitation of the S. S. Bevers family in the northwest quarter of Section 106. Over $90 \%$ of the site appears intact; it lacks subsurface deposits. The site has a low research potential and is judged to be not eligible for listing on the NRHP. No further work is recommended.

\section{$\underline{41 G R 375}$}

Location: Ca. $0.7 \mathrm{~km}$ WNW of confluence of Double Mountain Fork and Cat Hollow, and $2.1 \mathrm{~km}$ NNE of confluence of Double Mountain Fork and Rocky Creek. 
Description: Trash dump in uplands at head of unnamed drainage west of Cat Hollow; elevation $2300 \mathrm{ft} \mathrm{msl}$, area $78 \mathrm{~m}^{2}$. Scatter of recent trash ca. $10 \mathrm{~m}$ in diameter containing two historic artifacts. Dump site used only once or a few times; historic artifacts could have been introduced with recent trash. Temporal component is Historic.

Features: None.

Cultural Materials Observed/Collected: Historic artifacts are clear glass jar base with embossed label that reads "KERR GLASS MFG. CO, SAND SPRINGS OKLA. PAT. AUG. 31 1915" and brown glass medicine bottle with cork top and Owens Illinois logo on bottom which could date to 1929 or 1939. Recent trash includes tin cans, glass fragments, battery rods, and white crockery fragments. No collections made.

Shovel Test Data: None.

Site History: Identical to history of $41 \mathrm{GR} 304$ and $41 \mathrm{GR} 370$.

Assessment/Recommendations: Site 41GR375 apparently represents a dump associated with the habitation of the S. S. Bevers family in the northwest quarter of Section 106. Over $90 \%$ of the site appears intact; it lacks subsurface deposits. The site has a low research potential and is judged to be not eligible for listing on the NRHP. No further work is recommended.

\section{GR392}

Location: Ca. $3.0 \mathrm{~km} \mathrm{~S}$ of confluence of the Double Mountain Fork and Little Grape Creek, and $4.4 \mathrm{~km}$ ESE of confluence of Double Mountain Fork and Rocky Creek.

Description: Cattle company line camp/homestead site on sloping upland over Little Grape Creek; elevation $2270 \mathrm{ft} \mathrm{msl}$, area $400 \mathrm{~m}^{2}$. First recorded by GRC in 1982 as historlc dugout with stone fireplace, stone floor, stone path, and associated artifact scatter. Local informants attributed dugout to oliver Curtis. Current investigations verified previous data, except stone floor and path were not found. Dugout depression and concentration of artifacts are in rectangular area ca. $32 \times 24 \mathrm{ft}$. Dugout seems to have several feet of fill in it; stone floor could be burled under fill. Area is relatively undisturbed, although surface collection likely. Historic residence dating from late 1800 s to early 1900s. Temporal component is Historic.

Features: Dugout depression is ca. $2 \mathrm{ft}$ deep. In center of end is sandstone fireplace $4 \mathrm{ft}$ long, $3 \mathrm{ft}$ wide, and ca. $4 \mathrm{ft}$ high. Slabs of sandstone from fireplace have fallen into depression. Opening at base of fireplace is still buried, indicating considerable fill. Dense scatter of cultural materials in dugout.

Cultural Materials Observed/Collected: Cast iron stove parts, tin cans (hole-in-top type), machinemade bottles, blue enamelware, oval tobacco cans, oval brass pan bottom, brick fragments (yellow, tan, and red), crockery fragments, round nails, iron pail, wagon axle, and wagon hub. The 1982 survey form also mentions window glass fragments, various colored glass fragments, copper tub with tin sides, and barrel hub. No collections made. 
Shovel Test Data: None.

Site H1story: Site 41GR392 is located in Section 82, Block 5, a school tract of 640 acres which the General Land Office leased to The Lexington Ranch Company for grazing land during the 1890s (Garza County Deed Record 4:280-282, 302-304; Deed Record 5:159-161).

On March 14, 1900, N. P. Pyron, whose post office address was Dark in Scurry County, swore that he was a settler on Section 82 and made application to purchase that section and Sections 68,92 , and 94. A month later, he made an agreement with the firm of A. J. and F. M. Long in which Pyron leased Sections 68, 92, and 94, Block 5, to the Longs for 10 years. The Longs were to have use of the three sections for grazing and they, in turn, were to pay $\$ 75.00$ a year to Pyron, the state and county taxes, and payments due to the State School Fund by Pyron. If Pyron chose to sell the land, the sale could only occur with the agreement of the Longs and in such a fashion that their grazing lease would not be endangered. Neither party was to run more than 50 cattle per 640-acre section, and Pyron was to have the right to run his bunch of cattle, numbering approximately 35 head, on his home section (Section 82) in the Longs' pastures (Texas. General Land Office 1914; Garza County Deed Record 6:323-326).

Despite the apparent serlousness of his intentions, Pyron sold Sections 68, 82, 92, and 94 to 0. H. Curtis on July 20, 1900, for $\$ 600.00$ and Curtis' assumption of Pyron's debts to the State. On April 22, 1901, 0. H. Curtis sold the same property to I. E. Curtis, who held the land for two years before reselling it to 0 . $\mathrm{H}$. Curtis and $\mathrm{M}$. J. Brooks. On May 20, 1905, the Brookses conveyed their one-half interest in the sections to O. H. Curtis, who then sold Sections 82 and 94 to A. O. Scarborough of Scurry County. On the same day, Curtis also conveyed 125 head of stock cattle which were located on his Garza County ranch (Texas. General Land Office 1914; Garza County Deed Record 7:327-328; Deed Record 8:103-104, 297-299, 300).

A. 0. and Nannie Scarborough, who also owned Sections 66, 67, 81, 83, and 93 in Block 5, designated as their homestead Lot 1, Block 4, in Snyder (Garza County Deed Record 8:9197). Within a year, they had purchased Sections 68 and 92 in Block 5 and had designated Section 57, Block 5, as their homestead (see site 4lKT58) (Garza County Deed Record 8:549553). These designations of other homesteads so soon after their acquisition of Section 82 suggest that the Scarboroughs probably did not occupy 41 GR392 for a lengthy period of time, if at all.

On May 18, 1907, the Scarboroughs, now residents of Taylor County, sold Sections 81, 83, and 93, Block 5, to N. N. Rodgers, Jr. for $\$ 12,480.00$. The same day, in a separate transaction, they sold Sections 82, 92, and 94 of Block 5 to Rodgers for \$11,520.00 (Garza County Deed Record 10:236-238). The Rodgerses then moved into the dugout at $41 G R 392$ and lived there for approximately five years before designating the north half of Section 84 , Block 5, as their homestead (Garza County Deed Record 17:274-275).

A taped interview with Irene (Mrs. N. N.) Rodgers made on May 30, 1969, includes descriptions of the dugout at 41GR392 and of her life there as a young bride (Rodgers 1969). According to Rodgers, the dugout measured approximately $8 \times 10 \mathrm{ft}$. It had dirt walls and a roof which was made of old boards similar to those used to construct box-and-strip houses. The Rodgerses burned wood in a fireplace which kept them nice and warm. Furnishings consisted of a spring seat from their buggy which they set up outside the front door. Inside were a table built of boards with a water bucket on it, a chuck box in the southwest 
corner, and a bed in the southeast corner. The boards for the bed were elevated about $3 \mathrm{ft}$ off the floor to avoid rattlesnakes. They sat on boxes and their bedrolls were tarps. Water for drinking and cooking was hauled in a zinc bucket from a spring which was located about 300 to 400 yds from the dugout.

The Rodgerses stayed in the dugout for about a year and then moved to a newly constructed three-room house on the hill located northwest of the dugout which local people still call Rodgers Hill. In about 1913 they built another house, probably the homestead in the north half of Section 84 to which they referred in a legal record dated September 15 , 1914 (Garza County Deed Record 17:274-275). However, they retained ownership of Section 82, and Mrs. Rodgers did not sell their three sections along Little Grape Creek (81, 82, and 83, Block 5) until a year after Nonnie Rodgers' death in 1936. At that point, she conveyed the land to W. G. Williams for $\$ 14,400.00$ (Garza County Probate Record 2:443; Deed Record 39:224-225).

Assessment/Recommendations: Site 41 GR392 is the location of a dugout which may have served as a line camp for early cattle companies in the project area, such as that belonging to the Longs. The site is known to have been occupied by at least 1900 and was used either as a temporary camp or a semipermanent home until 1963 (Rodgers 1969).

Over $75 \%$ of the site appears intact; it contains subsurface deposits. The site has an excellent research potential and is judged to be potentially eligible for listing on the NRFP according to Criteria $A, B$, and D because of the longevity of its use, 1ts association with well-known local residents, and its integrity which makes it among the best-preserved dugouts located during the current investigations (41GR263, 41GR443, and 41GR474). Site 41 GR392 is located outside of the project area; therefore, it cannot be recommended for further work at this time. However, it is likely that excavation of the site could yield important information about local dugout construction and prerailroad material culture in the project area. Furthermore, prior to any archeological work, transcriptions of tapes (Rodgers 1969) concerning the site should be obtained and studied.

\section{$\underline{41 G R 412}$}

Location: Ca. $1.2 \mathrm{~km}$ SSW of confluence of Double Mountain Fork and Cat Hollow, and $0.4 \mathrm{~km}$ SE of confluence of Double Mountain Fork and Gobbler Creek.

Description: Housesite at head of small unnamed drainage on south canyon rim of Double Mountain Fork; elevation 2220-2260 ft msl, area $2500 \mathrm{~m}^{2}$. Scatter of historic artifacts ca. $50 \mathrm{~m}$ in diameter on canyon rim extending down into drainage area. Small ledge below rim is partially filled with charcoal, ash, and debris. Window glass and cut lumber in scatter indicate house or structure. Materials appear to date to early 1900s and later. Temporal component is Historic.

Features: None.

Cultural Materials Observed/Collected: Cut lumber with wire nails, hole-in-top tin cans, whiteware and crockery fragments, window glass fragments, fragments of manganesebleached glass, .30-caliber shell cases, tobacco "plug," and miscellaneous metal fragments. No collections made. 
Shovel Test Data: None.

Site History: Site 41 GR412 is located in Section 107, Block 5, a tract of approximately 640 acres which was surveyed on August 2, 1873, and patented to the Houston and Great Northern Railway Company on December 27, 1873 (Texas. General Land Office 1873d). By the early 1880s, the Rallroad's interest in the Garza County land had passed to the New York and Texas Land Company, Limited, a New York corporation. The Company's president, Ira H. Evans, then leased 137 surveys, including Section 107, Block 5, to J. W. Mooar Brothers, Cornelius and Sloan of Colorado, Mitchell County (Garza County Deed Record 3:29-32).

In 1895, long-standing litigation between the New York and Texas Land Company, which held the Houston and Great Northern sections, and the Houston and Texas Central Railroad Company was settled by dividing their Garza and Kent county holdings between them. As a result of the settlement, Frederic P. Olcott of Bernardsville, New Jersey, holder of the Houston and Texas Central Railroad Company, was granted 22 surveys in Kent County and 27 surveys in Garza County. One of the Garza County properties was Section 107, Block 5, on which site $41 \mathrm{GR} 412$ is located (Texas. General Land office 1873b).

On May 21, 1906, the Houston and Texas Central sold Section 107 to Tom Williams of Scurry County for $\$ 1280.00$. A scant four months later, Williams died, leaving as his heirs his mother, M. E. Williams, and five brothers and sisters. In 1913, the heirs sold the property to F. 0. Sorrells of Garza County for $\$ 3000.00$, and the Sorrellses sold the tract in February 1914 to N. N. Rodgers, Jr. (Garza County Deed Record 10:94-96; Probate Record 1:31-35; Deed Record 14:204-205, 585-586). Rodgers, and later his heirs, then held the land unt1l at least 1947, when Irene Rodgers applied for a new patent (Texas. General Land Office 1873d).

Assessment/Recommendations: Legal information suggests that 41 GR412 may have been utilized by a member of the Williams family after 1906 and before 1913 when it was sold to the Sorrells family. An informant has suggested that one of the early Nonnie Rodgers homes was located in Section 107, an observation which would mean that occupation of $41 \mathrm{GR} 412$ postdated 1914 (Ward 1987). However, artifacts observed at the site clearly predate the Rodgers ownership and may even predate the Williams ownership.

Over $50 \%$ of the site appears intact; 1t lacks subsurface deposits. The site has an unknown research potential but is judged to be potentially eligible for listing on the NRHP according to Criteria $A, B$, and D. At the present time, insufficient data are available to accurately assess the age of site 41GR412. It is recommended that the portion of the site adjacent to the project area be examined, that enough artifacts be identified to suggest a span of time during which the site might have been occupied, and that local informants be questioned about families or individuals who might have been associated with the site.

\section{GR416}

Location: Ca. $0.9 \mathrm{~km}$ NNE of confluence of the Double Mountain Fork and Rocky Creek, and $4.9 \mathrm{~km}$ WSW of confluence of Double Mountain Fork and Little Grape Creek. 
Description: Rock art site on vertical sandstone face on bluff overlooking Double Mountain Fork; elevation $2230 \mathrm{ft} \mathrm{msl}$, area $0.8 \mathrm{~m}^{2}$. Panel bearing two historic inscriptions. Could be related to 41GR412, historic residence site in vicinity. Temporal component is Historic.

Features: Panel of historic inscriptions measuring $160 \mathrm{~cm}$ long and $50 \mathrm{~cm}$ tall. Two dated inscriptions; first reads "E M WOODARD MAY.1st.1912," and second reads "BACK IN DEC 1917." Evidently both inscriptions were made by same person. For further information about inscriptions, see Appendix E.

Cultural Materials Observed/Collected: None.

Shovel Test Data: None.

Assessment/Recommendations: Over $90 \%$ of the site appears intact; it lacks associated subsurface deposits. The site has research potential and is judged to be potentially eligible for listing on the NRHP. However, initial field recording has exhausted the site's potential at this time, and no further work is recommended.

\section{$\underline{41 \mathrm{GR} 418}$}

Location: Ca. $0.3 \mathrm{~km}$ ESE of confluence of Double Mountain Fork and Rocky Creek, and $2.1 \mathrm{~km}$ SSW of confluence of Double Mountain Fork and Cat Hollow.

Description: Rock art site on vertical rock face in small canyon on south side of Double Mountain Fork; elevation $2230 \mathrm{ft} \mathrm{msl}$, area less than $1 \mathrm{~m}^{2}$. Single eroded panel of possible historic inscriptions. Inscriptions are barely legible, and date cannot be read clearly. Site may be associated with Dorward Ranch Site (41GR51). Temporal component is Historic.

Features: Panel of inscriptions ca. $50 \mathrm{~cm}$ wide and $50 \mathrm{~cm}$ tall. Only legible elements are "19," "4," and letters "VH." For further information about inscriptions, see Appendix E.

Cultural Materials Observed/Collected: None.

Shovel Test Data: None.

Assessment/Recommendations: Over $90 \%$ of the site appears intact; it lacks associated subsurface deposits. The site has research potential and is judged to be potentially eligible for listing on the NRHP. However, initial field recording has exhausted the site's potential at this time, and no further work is recommended.

\section{GR419}

Location: Ca. $0.2 \mathrm{~km}$ ENE of confluence of Double Mountain Fork and Rocky Creek, and $2.1 \mathrm{~km}$ SSW of confluence of Double Mountain Fork and Cat Hollow. 
Description: Rock art site on high vertical sandstone bluff face overlooking Double Mountain Fork; elevation $2200 \mathrm{ft} \mathrm{msl}$, area less than $1 \mathrm{~m}^{2}$. Large panel of graffiti with one historic inscription. Temporal component is Historic.

Features: Single historic inscription $56 \mathrm{~cm}$ long and $15 \mathrm{~cm}$ tall reads "W.G. McMEANS 6/19/28." For further information about inscriptions, see Appendix E.

Cultural Materials Observed/Collected: None.

Shovel Test Data: None.

Assessment/Recommendations: Over $90 \%$ of the site appears intact; it lacks associated subsurface deposits. The site has research potential and is judged to be potentially eligible for listing on the NRHP. However, initial field recording has exhausted the site's potential at this time, and no further work is recommended.

\section{GR428}

Location: Ca. $0.6 \mathrm{~km}$ SSE of confluence of Double Mountain Fork and Rocky Creek, and $5.0 \mathrm{~km}$ WSW of confluence of Double Mountain Fork and Little Grape Creek.

Description: Rock art site on vertical sandstone face on valley slope above small drainage on east side of Rocky Creek; elevation $2240 \mathrm{ft} \mathrm{msl}$, area less than $1 \mathrm{~m}^{2}$. Single possibly historic inscription. Temporal component is Historic.

Features: Single inscription ca. $24 \mathrm{~cm}$ long and $12 \mathrm{~cm}$ high reads "VALO...THVS." It is quite weathered and only partially legible; amount of weathering suggests that inscription is historic. For further information about inscription, see Appendix E.

Cultural Materials Observed/Collected: None.

Shovel Test Data: None.

Assessment/Recommendations: Over 50\% of the site appears intact; it lacks associated subsurface deposits. The site has research potential and is judged to be potentially eligible for listing on the NRHP. However, initial field recording has exhausted the site's potential at this time, and no further work is recommended.

\section{$\underline{41 G R 437}$}

Location: Ca. $1.6 \mathrm{~km}$ SSW of confluence of Double Mountain Fork and Rocky Creek, and $6.0 \mathrm{~km}$ SW of confluence of Double Mountain Fork and Little Grape Creek.

Description: Rock art site in overhang shelter near base of bluff overlooking Double Mountain Fork; elevation $2230 \mathrm{ft} \mathrm{msl}$, area less than $1 \mathrm{~m}^{2}$. Overhang extends for considerable distance along bluff face, with several small chambers formed by wind and water. Floor of shelter is bare sandstone. Two shelter areas are ca. $20 \mathrm{~m}$ apart; one contains 
prehistoric petroglyphs, while other contains historic inscriptions. Historic shelter ca. $20 \mathrm{~m}$ long and $5 \mathrm{~m}$ deep has inscriptions on back wall in panel ca. $50 \mathrm{~cm}$ long and $50 \mathrm{~cm}$ tall. Temporal components are Historic and undefined Prehistoric (see Appendix F for description of prehistoric component).

Features: Two historic inscriptions; first is ca. $30 \mathrm{~cm}$ long and $10 \mathrm{~cm}$ tall and reads "1899." Second is ca. $50 \mathrm{~cm}$ long and $20 \mathrm{~cm}$ tall and reads "H. NUNN" followed by a date which is illegible. For further information on inscriptions, see Appendix E.

Cultural Materials Observed/Collected: None.

Shovel Test Data: None.

Assessment/Recommendations: Over $90 \%$ of the historic inscriptions appear intact; they lack associated subsurface deposits. The historic inscriptions have research potential and are judged to be potentially eligible for listing on the NRHP. However, initial field recording has exhausted the site's potential at this time, and no further work is recommended.

\section{$\underline{41 G R 443}$}

Location: Ca. $2.0 \mathrm{~km}$ SSW of confluence of Double Mountain Fork and Rocky Creek, and $6.4 \mathrm{~km}$ SW of confluence of Double Mountain Fork and Little Grape Creek.

Description: Sheepherders camp, homestead site on beđrock terrace over Rocky Creek, rlght against base of bluff slope; elevation $2250 \mathrm{ft} \mathrm{msl,} \mathrm{area} 6000 \mathrm{~m}^{2}$. Historic dugout homestead incorporating remains of residence, small outbuilding, corral, and scatter of historic debris concentrated around area of outbuilding. Residential structure is dugout excavated out of base of bluff slope, with outbuilding directly in front and ca. $30 \mathrm{ft}$ downslope. Artifact scatter on downslope side of outbuilding measures ca. $65 \times 33 \mathrm{ft}$, with concentration ca. $16 \mathrm{ft}$ in diameter at one end of scatter. Corral is adjacent to base of bluff ca. $100 \mathrm{ft}$ from dugout. Undisturbed except for some uncontrolled excavations in corral; surface collection also is likely. Historic homestead of moderate size in good state of preservation. Temporal component is Historic.

Features: Three structures of local sandstone: dugout, outbuilding, and corral. Dugout is partially covered by colluvium; visible remains indicate interior area of $5 \times 4 \mathrm{ft}$, with exterior dimensions of ca. $8 \times 6 \mathrm{ft}$. Outside structure is scatter of sandstone fragments and cut wood remnants, with knife blade, old flashlight, and two large slabs of sandstone, one buried in vertical position. Outbuilding ca. $33 \mathrm{ft}$ downslope from dugout is composed of ca. 20-ft-diameter scatter of sandstone cobbles, with artifact scatter on downslope side. Corral ca. $100 \mathrm{ft}$ downstream of dugout along base of bluff is composed of open-sided, ca. 53×37-ft rectangle of sandstone cobbles. In one corner, enclosed area ca. $18 \times 7 \mathrm{ft}$ is remains of pen. Two uncontrolled excavations within pen.

Cultural Materials Observed/Collected: Thick tin cans with soldered side seam; purple, green, brown, and clear glass fragments; two square-cut nails; flashlight; barbed wire pieces; two horseshoes; snuff can 11d; and various metal fragments. Three items collected (see Appendices A and B). 
Shovel Test Data: Two negative shovel tests; one in dugout contained two charcoal fragments at 20-40 cm and found soil depth of ca. $45 \mathrm{~cm}$. Other test in enclosed area of corral indicated soil depth of ca. $60 \mathrm{~cm}$.

Site History: Site 41 GR443 is located in Section 114, Block 5, a school tract of 640 acres on which The Lexington Ranch Company paid taxes in 1886 and leased from the General Land Office for grazing purposes in 1888 and 1891 (Garza County Deed Record $\underline{4}$ :83-85, 302304).

On February 22, 1900, S. D. "Dee" Boren, a cowboy who worked with the Longs, swore that he was a settler on Section 114, Block 5, and declared that he wished to purchase it. Three years later in Borden County, Boren again swore that he was an actual settler on the Section, and his claim of three-years' occupancy was supported by fellow os cowboys and neighbors O. B. Kelly, Carl Clark, and Will Williams (Texas. General Land Office 1919b).

According to a nephew, Dee Boren and his brothers James Minus Boren and John Boren worked for the Longs on their ranch (Boren 1978, 1987). The Longs had bought a lease from Overstreet off the Caprock over near Fluvanna and then acquired Lexington Ranch Company leases until they had a total of about 149 sections leased. The Longs spent most of their time in Sweetwater, but their hands, who included the Borens, Ed Scott, Will Williams, 0. B. Kelly, and Walter Roy, stayed on Grape Creek in a half dugout (possibly 4lKT84) which was located south of the project area. They patrolled the area and, according to a family member, chased off a white sheepherder who had made camp in Section 114 on Rocky Creek (Boren 1978, 1987).

By the end of the 1890s, the Longs saw that they were going to lose their State leases on school lands due to interest in the area by permanent settlers and changing land laws, and so they induced their hands each to file on a homestead section and three additional grazing sections. Dee Boren, whose neighbors included OS cowboys William Williams, John and J. M. Boren, O. B. Kelly, and Walter Roy, claimed Section 114 (Boren 1987; U.S. Bureau of the Census 1900).

It seems likely that Dee Boren simply moved into the camp made by the sheepherders and made it his own. Eventually, he moved to Sweetwater, but he kept Section 114 until the 1920 s when he lost it to the First National Bank in Post. It was acquired by J. C. Dorward in the 1930s (Garza County Tax Assessors Abstracts 1916-1936; Boren 1987).

Assessment/Recommendations: Site 41 GR 443 is a well-preserved site which appears to have been constructed and occupied initially by sheepherders. An informant places the sheepherders' occupation at the site sometime during the 1890s. The Section on which the site is located was subsequently claimed by OS cowboy Dee Boren, who probably utilized the earlier improvements.

At the present time, the site is assumed to have been occupied by the $1890 \mathrm{~s}$, but the possibility that it was occupied at an earlier date should be explored. Over $50 \%$ of the site appears intact; it may contain subsurface deposits. The site has an excellent research potential and is judged to be potentially eligible for listing on the NRHP according to Criteria $A$ and $D$. It is recommended that the site, like 41 GR263 and 41 GR443, be nominated for listing on the NRHP, further research be done by means of oral histories and examination of archival records, and that the site be tested by hand excavation. The site should be accurately mapped and a controlled surface collection made so that more 
information concerning the history of occupation and prerailroad material culture in the project area can be obtained.

\section{GR445}

Location: Ca. $1.9 \mathrm{~km}$ SSW of confluence of Double Mountain Fork and Rocky Creek, and $6.2 \mathrm{~km} \mathrm{SW}$ of confluence of Double Mountain Fork and Little Grape Creek.

Description: Rock art site at bottom of vertical rock face near base of bluff overlooking Rocky Creek; elevation $2240 \mathrm{ft} \mathrm{msl}$, area $37.5 \mathrm{~m}^{2}$. Large number of historic and recent inscriptions carved into sandstone panel ca. $15 \mathrm{~m}$ long and $2.5 \mathrm{~m}$ high. Some elements could be historic or prehistoric. Panel is badly eroded and has been shot several times, so most inscriptions are 1llegible. Some recent debris on site. Temporal components are Historic and undefined Prehistoric (see Appendix $F$ for description of prehistoric component).

Features: Nine legible historic inscriptions on panel. First two inscriptions are ca. $1 \mathrm{~m}$ long and $30 \mathrm{~cm}$ tall and read "Robert Benem" and "NAN OA"; nearby "1854" ("5" is uncertain) inscription may be associated with elther or both. Third inscription reads "DEE BOYEN Moved Aug 5 19...." Fourth is ca. $1 \mathrm{~m}$ long and $20 \mathrm{~cm}$ tall and reads "ROSA BOYEN AUG 5 1901." Although middle letter in last names of third and fourth inscriptions appears to be "Y," It is probably a stylistic variation meant to represent "R" (1.e., BOREN). Fifth is ca. $20 \mathrm{~cm}$ long and $4 \mathrm{~cm}$ tall and reads "3/11 1917." Sixth is ca. $40 \mathrm{~cm}$ long and $5 \mathrm{~cm}$ tall and reads "L C J 1911-11-11." Seventh is ca. $50 \mathrm{~cm}$ long and $7 \mathrm{~cm}$ tall and reads "C. MANN 1881." Eighth is $40 \mathrm{~cm}$ long and $15 \mathrm{~cm}$ tall and reads "VERNE WLdEN 12-1917." Ninth is ca. $80 \mathrm{~cm}$ long and $30 \mathrm{~cm}$ tall and reads "X: K. Boren 1901." For further information about. Inscriptions, see Appendix E.

Cultural Materlals Observed/Collected: None.

Shovel Test Data: None.

Assessment/Recommendations: This site contains several historic dates and the names of people known historically in the area. Less than $50 \%$ of the historic inscriptions appear intact; they lack associated subsurface deposits. The historic inscriptions have research potential and are judged to be potentially eligible for listing on the NRHP. It is recommended that the historic inscriptions be fully documented with photographs and detalled drawings.

\section{$41 \mathrm{GR} 448$}

Location: Ca. $1.6 \mathrm{~km}$ SSW of confluence of Double Mountain Fork and Rocky Creek, and $6.1 \mathrm{~km}$ SW of confluence of Double Mountain Fork and Little Grape Creek.

Description: Rock art site in wind-eroded shelter on bluff face overlooking Rocky Creek; elevation $2240 \mathrm{ft} \mathrm{msl}$, area less than $1 \mathrm{~m}^{2}$. Panel of historic rock art and inscriptions ca. $80 \mathrm{~cm}$ long and $60 \mathrm{~cm}$ tall. Temporal component is Historic. 
Features: Two historic inscriptions, one with drawing. This inscription is ca. $50 \mathrm{~cm}$ long and $60 \mathrm{~cm}$ tall and reads "CECIL BOREN DEC. 27, $1917 \mathrm{MD} \ldots . . . "$ Above name is drawing of face ca. $30 \mathrm{~cm}$ tall and $25 \mathrm{~cm}$ wide, with round head and wide-brimmed conical hat, eyes, eyebrows, nostrils, mouth, and neck. To right of face is set of initials ca. $15 \mathrm{~cm}$ long and $7 \mathrm{~cm}$ tall reading "BJF." Second inscription is ca. $25 \mathrm{~cm}$ tall and $15 \mathrm{~cm}$ wide and reads "ALC V.A L. 1941." For further information about inscriptions, see Appendix E.

Cultural Materials Observed/Collected: None.

Shovel Test Data: None.

Assessment/Recommendations: Over 90\% of the site appears intact; it lacks associated subsurface deposits. The site has research potential and is judged to be potentially eligible for listing on the NRHP. However, initial field recording has exhausted the site's potential at this time, and no further work is recommended.

\section{$41 \mathrm{GR} 449$}

Location: Ca. $1.8 \mathrm{~km}$ SSW of confluence of Double Mountain Fork and Rocky Creek, and $6.2 \mathrm{~km}$ SW of confluence of Double Mountain Fork and Little Grape Creek.

Description: 011 pumper's housesite on upland knoll overlooking Rocky Creek; elevation 2250-2270 ft msl, area $5600 \mathrm{~m}^{2}$. Remains of historic residence include house foundation, windmill, oil pad, small alignment of rocks, few sandstone slabs, and scatter of historic debris. Landscape features domestic vegetation. Materials appear to date to 1930s. Temporal component is Historic.

Features: House foundation, windmill, alignment of rocks, sandstone slabs, domestic vegetation, and well pad.

Cultural Materials Observed/Collected: Toy locomotive, tin cans, glass fragments, china fragments, cinder blocks, bricks, asphalt siding, and asbestos insulation. No collections made.

Shovel Test Data: None.

Site History: The history of site 41 GR449 is 1dentical to that of 41 GR443 until after the acquisition of Section 114, on which the two sites are located, by James Clinton Dorward in the 1930s. According to local informants (Blackard 1987; Blakey 1987), Dorward used the land for ranching purposes and his headquarters were located in the northeastern quadrant of Section 138. At an as-yet-undetermined date, a considerable amount of oil exploration and drilling occurred on the ranch, and an o1l company constructed several pumper's houses on the ranch. One of these houses was located at site 41 GR449 and was occupied unt11 the 1950s when it was destroyed or removed from the site. Occupants were families of pumpers who watched the operations of the oil field and took care of the wells.

Assessment/Recommendations: Site 41GR449, the former location of an oil companyconstructed pumper's house, is in relatively good condition with readily discernible site and landscape features. The house which stood at the site has been compared by an 
informant to a 1930s or 1940s frame bungalow which was also constructed by an oil company and still stands a short distance away to the west (Blakey 1987). Over 50\% of the site appears intact; it lacks subsurface deposits. The site has an unknown research potential and is judged to be potentially eligible for listing on the NRHP.

Despite the integrity of the site and profuseness of artifacts, it is difficult to assign a level of significance to $41 \mathrm{GR} 449$ or to judge its National Register eligibility according to Criteria $\mathrm{A}$ and D. Recent (ca. 40 years old) structures or sites associated with the development of the West Texas oil industry have not been addressed in the State Plan. However, a minimal amount of further work might reasonably include mapping the site and collecting representative artifacts which could be used for comparative purposes with those from contemporaneous and functionally similar sites in areas of Texas where oil development occurred. In addition, because records for such sites often are as ephemeral or nonexistent as those for tenant farms of the early twentieth century, it is recommended that some attempt be made to locate and make an oral history tape of a former resident of the site.

\section{$\underline{41 G R 455}$}

Location: Ca. $0.7 \mathrm{~km}$ SSW of confluence of Double Mountain Fork and Rocky Creek, and $5.2 \mathrm{~km}$ SW of confluence of Double Mountain Fork and Little Grape Creek.

Description: Rock art site on eroded rock face on bluff overlooking Rocky Creek; elevation 2220-2240 ft msl, area less than $1 \mathrm{~m}^{2}$. Slight overhang has bistoric inscription. Temporal component is Historic.

Features: Inscription ca. $40 \mathrm{~cm}$ long and $26 \mathrm{~cm}$ tall reads "Lee Tuffing Spring ...1913." For further information on inscription, see Appendix E.

Cultural Materials Observed/Collected: None.

Shovel Test Data: None.

Assessment/Recommendations: Over $90 \%$ of the site appears intact; it lacks associated subsurface deposits. The site has research potential and is judged to be potentially eligible for listing on the NRHP. However, initial field recording has exhausted the site's potential at this time, and no further work is recommended.

\section{$\underline{41 G R 460}$}

Location: Ca. $0.7 \mathrm{~km} \mathrm{NE}$ of U.S. Highway 84 bridge over Sand Creek, and $1.6 \mathrm{~km}$ SSW of confluence of Double Mountain Fork and Sand Creek.

Description: Rock wall on lower alluvial terrace of Sand Creek at base of small erosional remnant knoll; elevation $2240 \mathrm{ft} \mathrm{msl}$, area $72 \mathrm{~m}^{2}$. Wall of sandstone slabs and cobbles that apparently served as water diversion structure or base support for barbed wire fence now gone. Temporal component is Historic, possibly recent. 
Features: Stone wall ca. $29 \mathrm{ft}$ long and $3 \mathrm{ft}$ wide, with one end anchored to large bedrock exposure. Barbed wire used in its construction, since plece of barbed wire is tied to one of rocks fallen from wall. Otherwise, dry-stone construction was employed. Wall curves slightly at point near center where it apparently has been washed away. Wall is 3 ft tall at highest point.

\section{Cultural Materials Observed/Collected: None.}

Shovel Test Data: None.

Site History: Site 41 GR460 is located in Section 13, Block 6, a 640-acre tract which was surveyed on August 3, 1873, and patented on December 9, 1873, to the Houston and Great Northern Railway Company. The section was crossed by what was called Sandy Creek in 1873; by 1895 when it was resurveyed, the south and west lines of the section crossed the northwesterly running Snyder and Estacado Road (Texas. General Land Office 1873e).

By November 1880, Section 13 and a number of other sections had been conveyed to the New York and Texas Land Company, Ltd. (Texas. General Land Office 1873b), and that company leased a total of 137 surveys of 640 acres each for grazing purposes to J. W. Mooar Brothers (Garza County Deed Record 3:29-32). Fifteen years later, the land became the focus of a dispute between individuals who held the property interests of the New York and Texas Land Company and the Houston and Texas Central Rallway Company. In December 1895, the two parties agreed to divide the land between them, and Section 13, Block 6 , became one of the tracts conveyed to Thomas R. White, Jr. of Union County, New Jersey (Texas. General Land Office 1873b).

White held Section 13 unt1l March 16, 1901, when he acted through his agent, Ira H. Evans, to sell Sections 13, 15, and 17, Block 6, to Jeff D. Justice for $\$ 4080.00$ (Garza County Deed Record 7:561-565) whose homestead (41GR474) was located on the south half of Section 20, Block 6 (Texas. General Land Office 1939b).

Justice, who platted and promoted the town of Justiceburg where he owned a store and lumberyard (Didway 1973:24) continued to make his home on the south part of Section 20 and to run stock on other sections, including Section 13, until his death on January 2, 1934 (The Post Dispatch, January 4, 1934), at which time his property passed to his widow, Mattie Justice. Section 13 remains part of the Justice family property today.

Assessment/Recommendations: No information was located during the current investigations which indicated an age or function for site 41GR460. An informant noted that the Justice family leased Section 13 at one time for a gravel operation (Blakey 1987), and the tax assessment on the Section rose from $\$ 1540.00$ in 1921-1923 to $\$ 4545.00$ in 1924-1927, suggesting the construction of a major improvement which may have been associated in some way with etther 41 GR460 or 41GR530. Less than $50 \%$ of the site appears intact; it lacks associated subsurface deposits. The site has an unknown research potential but is judged to be potentially eligible for listing on the NRHP according to Criterion D. Because of the lack of substantive information about this site, it is recommended that an attempt be made to locate a member of the Justice family who can identify the feature and provide information about its functional relationship to 41GR530. 
Location: Ca. $1.0 \mathrm{~km} \mathrm{NW}$ of confluence of Double Mountain Fork and Sand Creek, and 4.8 $\mathrm{km} \mathrm{SE}$ of intersection of U.S. Highway 84 and FM 2458.

Description: Rock art site in shallow depression eroded from vertical sandstone face on bluff slope over Rocky Creek; elevation $2260 \mathrm{ft} \mathrm{msl}$, area $13.75 \mathrm{~m}^{2}$. Two panels contain both historic and recent inscriptions. Area covered by panels measures ca. $3 \mathrm{~m}$ long and $1.25 \mathrm{~m}$ tall, most of which is covered with recent inscriptions. Temporal component is Historic.

Features: Two panels of historic inscriptions and recent graffiti. First panel is ca. $1.5 \mathrm{~m}$ long and $1.25 \mathrm{~m}$ tall and contains two historic inscriptions. First is ca. $35 \mathrm{~cm}$ long and ca. $10 \mathrm{~cm}$ tall and reads "C J LEININ.... 1112 18." "L" is drawn so that horizontal line underscores first four letters of name; letters after "L" are ca. one-third size of initials. C. J. Leininger's name appears on several rock art sites in area. Second inscription in historic lettering style; ca. $25 \mathrm{~cm}$ long and $10 \mathrm{~cm}$ tall, it reads "JC PINTLE 6/30." Date could either be June 30th or June 1930; latter is assumed.

Second panel is ca. $1.5 \mathrm{~m}$ long and $1.25 \mathrm{~m}$ tall, with three historic inscriptions. First is ca. $75 \mathrm{~cm}$ long and $7 \mathrm{~cm}$ tall and reads "ANNA LEA COWAN." Second is ca. $90 \mathrm{~cm}$ long and $15 \mathrm{~cm}$ tall and reads "E. COWAN MAY 71915 FLUVANNA TEX." Third is ca. $90 \mathrm{~cm}$ long and $20 \mathrm{~cm}$ tall and reads "BILL. COWAN SUNDAY FIShing IS A SIN." In all these inscriptions, letter "N" is written backwards, which supports an historic date, although only one is dated. For further information about inscriptions, see Appendix E.

Cultural Materials Observed/Collected: None.

Shovel Test Data: None.

Assessment/Recommendations: Over $90 \%$ of the site appears intact; it lacks associated subsurface deposits. The site has research potential and is judged to be potentially eligible for listing on the NRHP. However, initial field recording has exhausted the site's potential at this time, and no further work is recommended.

\section{GR465}

Location: Ca. $4.7 \mathrm{~km}$ SE of intersection of U.S. Highway 84 and FM 2458 , and $2.2 \mathrm{~km}$ NNE of U.S. Highway 84 bridge over Sand Creek.

Description: Rock art site on vertical sandstone face on bluff overlooking Rocky Creek; elevation $2260 \mathrm{ft} \mathrm{msl}$, area less than $1 \mathrm{~m}^{2}$. Single historic inscription dated 1918 and 1925. Temporal component is Historic.

Features: Inscription ca. $30 \mathrm{~cm}$ long and $20 \mathrm{~cm}$ tall reads "C.J.L. 11-12-18" and "5-1-25." For further information about inscription, see Appendix E.

Cultural Materials Observed/Collected: None. 
Shovel Test Data: None.

Assessment/Recommendations: Over $90 \%$ of the site appears intact; it lacks associated subsurface deposits. The site has research potential and is judged to be potentially eligible for listing on the NRHP. However, initial field recording has exhausted the site's potential at this time, and no further work is recommended.

\section{$\underline{41 G R 470}$}

Location: Ca. $2.3 \mathrm{~km}$ SSE of U.S. Highway 84 bridge over Double Mountain Fork, and 2.7 km NNW of U.S. Highway 84 bridge over Sand Creek.

Description: Railroad/resort complex on lower alluvial terrace of Double Mountain Fork on floodplain of small side drainage; elevation 2240-2260 ft msl, area $250,000 \mathrm{~m}^{2}$. Reservoir and associated building complex built by Santa Fe Railroad and by private individuals. Lake was built to provide source to supply early steam engine locomotives with water before climb to top of Caprock Escarpment. Structures include pumphouse with water intake and connecting walkway, two houses, and associated outbuilding. Artifact scatters include two trash dumps and several other areas. Site was water source for railroad until 1950 s and continued to be used into recent times. Temporal classification is Historic.

Features: Seven structural features on site. Concrete pumphouse (largest building) is $25 \mathrm{ft}$ long and $12 \mathrm{ft}$ wide, with small rectangular structures outside building connected with raised wooden walkways. Water intake is $25 \mathrm{ft}$ tall and 8-ft-diameter tower of red brick, connected to pumphouse by raised walkway.

Two houses were used by Garza County residents for recreational purposes. One house is ca. $28 \mathrm{ft}$ long and $14 \mathrm{ft}$ wide, with sandstone walls; roof and interior walls are missing. Hogwire pen built onto front of building. Other house, ca. $15 \mathrm{ft}$ long and $13 \mathrm{ft}$ wide, is made of sandstone slabs, with concrete floor, tin roof, and chimney. Associated artifact scatters contain materials from all periods of houses' occupation.

Fourth feature is shallow concrete foundation ca. $3 \mathrm{ft}$ square between the spillway and the dam surrounded by cut lumber and a trash scatter. This may have been location of recreational camphouse.

Fifth feature is outhouse ca. $1000 \mathrm{ft}$ away from pumphouse; apparently moved after indoor plumbing was installed.

Sixth feature is earthen dam ca. $525 \mathrm{ft}$ long, with lake slde lined with concrete.

Seventh feature is spillway below dam, which was blasted and cut out of sandstone bedrock. Now partially filled with debris from entire span of occupation.

Cultural Materials Observed/Collected: Abundant trash scattered on site, with several concentrations and dump areas. Artifacts date to all periods of site's use. Historic materials include manganese-bleached glass fragments, hole-in-top tin cans, and pieces of glass and whiteware with identifiable base markings. No collections made. 
Shovel Test Data: None.

Site History: Site 41GR470 is located in Sections 12 and 19, Block 6. Section 12, 640 acres of Garza County School Land, was purchased as grazing land in 1900 by W. B. Justice, who then conveyed the property to Jeff D. Justice for $\$ 960.00$ on April $10,1903$. Included in the conveyance were Sections 12 and 18, the east half of Section 30 , and the north half of Section 20, Block 6 (Texas. General Land Office 1939a; Garza County Deed Record 9:600-601).

By 1910 the Gulf, Colorado and Santa Fe Rallway had constructed a line west of 41 GR470 resulting in the platting of two new towns - Burnham in Section 24 and Justiceburg in Section 25. Another result of the railroad construction was the building of Justiceburg Lake in the northeast quarter of Section 19 and the northwest quarter of Section 12, Block 6. The Lake was constructed on land belonging to Jeff D. Justice, and its purpose was to provide water to the train engines at the Justiceburg station. Water was pumped from the Lake through a pipe to a standpipe near Justiceburg, then ran by gravity flow to the train.

Over a period of time, the Lake became renowned for its fine fishing, and local residents received permission to build small cabins there. Over a number of years, a fishing camp developed around the Lake and included single- and multi-roomed facilities with porches, screens, and tarps, and a house (41GR203) located in the northeast corner of Section 20 which was occupied by the caretaker who looked over the Lake and railroad facilities there (Blakey 1987).

Assessment/Recommendations: This site, together with the historic component of site 41GR203, constitutes a large historic industrial and resort complex which operated between ca. 1910 and recent times and was associated with the construction and operation of the Santa Fe Railroad after 1910. It is included in the Texas Historic Sites Inventory (Texas Historical Commission) and in the Historic Engineering Site Inventory (Texas Tech University). Over $75 \%$ of the site appears intact; it lacks subsurface deposits but has standing structures and machinery. The site has an excellent research potential and is judged to be potentially eligible for listing on the NRHP according to Criteria A, C, and D. It is recommended that the site be accurately mapped and a controlled surface collection made. Research should consist of further work in the Garza County deed records to determine when the Railroad purchased the property, conducting of oral interviews with local residents familiar with the railroad and resort functions of the site, and examination of railroad company records. Historic American Engineering Records drawings and photographs should be made of the pumphouse, dam, and spillway.

\section{GR473}

Location: Ca. $3.0 \mathrm{~km} \mathrm{SE}$ of intersection of U.S. Highway 84 and FM 2458 , and $2.8 \mathrm{~km} \mathrm{NW}$ of confluence of Double Mountain Fork and Sand Creek.

Description: Rock art site on vertical sandstone face on bluff overlooking Double Mountain Fork; elevation $2250 \mathrm{ft} \mathrm{msl}$, area $25 \mathrm{~m}^{2}$. Panel ca. $5 \mathrm{~m}$ long and $5 \mathrm{~m}$ tall contains numerous recent inscriptions and three historic inscriptions identified by date or style of lettering. Temporal component is Historic. 
Features: Three inscriptions; first is $\mathrm{ca} .70 \mathrm{~cm}$ long and $10 \mathrm{~cm}$ tall and reads "AHJ APRL 10 1901." Second is ca. $85 \mathrm{~cm}$ long and $20 \mathrm{~cm}$ tall and reads "BUFORD BROWNING" above "JESSE "[ditto mark]." This latter inscription indicates "JESSE BROWNING." Third inscription is partly spalled; extant size is $\mathrm{ca} .50 \mathrm{~cm}$ long and $17 \mathrm{~cm}$ tall, and it reads "GJ APRI 10." For further information about inscriptions, see Appendix E.

Cultural Materials Observed/Collected: None.

Shovel Test Data: None.

Assessment/Recommendations: Over $90 \%$ of the site appears intact; it lacks associated subsurface deposits. The site has research potential and is judged to be potentially eligible for listing on the NRHP. However, initial field recording has exhausted the site's potential at this time, and no further work is recommended.

\section{$\underline{41 G R 474}$}

Location: Ca. $2.5 \mathrm{~km}$ SE of intersection of U.S. Highway 84 and FM 2458 , and $1.5 \mathrm{~km} \mathrm{E}$ of U.S. Highway 84 bridge over Double Mountain Fork.

Description: Homestead site at end of upland ridge within meander of Double Mountain Fork; elevation 2220-2260 ft msl, area 150,000 $\mathrm{m}^{2}$. Large historic homestead with associated scatter of debris overlying prehistoric artifact scatter. Includes remains of dugout, subsequent house, windmill, clstern, and corral. Dugout is located on edge of ridge overlooking deflating area, ca. $655 \mathrm{ft}$ downslope from location of later house. Remaining features are located within $245 \mathrm{ft}$ of house, and artifact scatter is concentrated in this area. Disturbed by dirt road which runs through center of site along top of ridge and by erosion and deflation along edges of ridge. Residence of Jeff Justice, for whom Justiceburg is named. Dugout dates to ca. 1900, while house dates to ca. 19.20s-1940s. Temporal components are Historic and Late Prehistoric (see Appendix F for description of prehistoric component).

Features: Five features: dugout, house, cistern, outbuilding, and corral. Dugout is surrounded by artifact scatter and is separated from other features by ca. $655 \mathrm{ft}$. Dugout consists of rough rectangle of stones, with interior area ca. $24 \mathrm{ft}$ long and $14 \mathrm{ft}$ wide.

House is indicated by scattered pile of red bricks, probably remains of chimney foundation. Nearby cistern made of sandstone and lined with concrete has exterior diameter of ca. 31 inches. $\mathrm{Ca}$. $100 \mathrm{ft}$ from house and cistern are remains of wooden structure constructed with wire nails that may have been outbuilding. Corral on opposite side of house, next to edge of ridge, is in very poor condition. It is made of wooden fence posts and wire and is ca. $100 \mathrm{ft}$ long and $50 \mathrm{ft}$ wide.

Cultural Materials Observed/Collected: Fragments of manganese-bleached, brown, and clear bottle glass; crockery; whiteware; bed springs; hole-in-top tin cans; stovepipe; coffee pot; blue enameled pots; kerosene lantern base and top; windmill parts; milled wood fragment; top to butter churn; horseshoe nail; brass shell case; stove parts; and miscellaneous metal fragments. One item collected (see Appendices A and B). 
Shovel Test Data: None.

Site History: Site 41GR474 is located in the south half of Section 20, Block 6, a 320-acre tract which was one part of numerous sections leased to The Lexington Ranch Company of Nolan County by the General Land Office between 1888 and ca. 1896 (Garza County Deed Record 4:83-85, 280-282, 302-304; Deed Record 5:159-161). On February 17, 1900, Jeff Justice made application and filed an affidavit in Colorado [City], Texas, stating that he was an actual settler on the tract and desired to purchase the land from the State. Three years later, Justice's statements were verified by three witnesses who were residents of Scurry County (Texas. General Land Office 1939b).

According to an affidavit made by T. J. Payne whose homestead was on Section 26, he, T. E. Payne, Jeff Justice, and W. B. Justice had made camps in the project area for the purpose of establishing homestead claims by December 1899 (Texas. General Land Office 1936). It must have been shortly after this that Justice constructed and occupled the dugout at 41GR474. Occupation of the dugout must have been very brief, however, if the county history which states that he moved into a new ranch house in 1900 is correct (Didway 1973:24).

Jeff D. Justice occupied site 4IGR474 until his death on January 2, 1934 (The Post Dispatch, January 4, 1934); his widow then occupied the site, which still remains in family hands.

Assessment/Recommendations: Site 41GR474 is the location of a dugout, housesite, and associated site features which was owned and occupied after 1899 by Jeff D. Justice, a prominent West Texas rancher who platted and promoted the town of Justiceburg. The site is also significant because it includes a prerailroad component (the dugout) and was occupied throughout the postrailroad era. Over $90 \%$ of the historic component appears intact; it contains structural remains but may lack subsurface deposits. The historic component has an excellent research potential and is judged to be potentially eligible for listing on the NRHP according to Criteria $A, B$, and D. It is recommended that the site be tested by hand excavation, that it be accurately mapped, that a controlled surface collection be made, and that the dugout feature be compared with dugout features at sites 41GR263, 41GR392, and $41 \mathrm{GR} 443$.

\section{$\underline{41 G R 475}$}

Location: Ca. $3.1 \mathrm{~km} \mathrm{SE}$ of intersection of U.S. Highway 84 and FM 2458 , and $2.6 \mathrm{~km}$ NNW of confluence of Double Mountain Fork and Sand Creek.

Description: Rock art site on vertical sandstone face on bluff overlooking Double Mountain Fork; elevation $2240 \mathrm{ft} \mathrm{msl}$, area $1.5 \mathrm{~m}^{2}$. Two historic inscriptions carved into rock face covering area ca. $3 \mathrm{~m}$ long and $0.5 \mathrm{~m}$ tall. Recent graffiti has not damaged historic inscriptions. Temporal components are Historic.

Features: Two inscriptions. One is $50 \mathrm{~cm}$ long and $35 \mathrm{~cm}$ tall and reads "CJL [C. J. Leininger] 10/11/15." Other inscription is $180 \mathrm{~cm}$ long and ca. $50 \mathrm{~cm}$ tall and reads "FE 10/14/1," with numbers ca. twice as large as letters. The last number probably indicates 1901. For further information about inscriptions, see Appendix E. 
Cultural Materials Observed/Collected: None.

Shovel Test Data: None.

Assessment/Recommendations: Over $90 \%$ of the site appears intact; it lacks associated subsurface deposits. The site has research potential and is judged to be potentially eligible for listing on the NRHP. However, initial field recording has exhausted the site's potential at this time, and no further work is recommended.

\section{GR494}

Location: Ca. $2.5 \mathrm{~km} \mathrm{NE}$ of confluence of Double Mountain Fork and Sand Creek, and 7.0 $\mathrm{km}$ SSE of intersection of U.S. Highway 84 and FM 2458.

Description: Rock art site below sandstone overhang forming sheltered area on bluff overlooking head of small drainage to Double Mountain Fork; elevation $2260 \mathrm{ft}$ msl, area 60 $\mathrm{m}^{2}$. Sheltered area is ca. $20 \mathrm{~m}$ long and $3 \mathrm{~m}$ deep; floor of shelter is bedrock, with thin deposit of eolian sand. Sands are deeper outside shelter but contain no cultural deposits. Aboriginal rock art and historic inscriptions carved into back wall of shelter, in panel ca. $4.5 \mathrm{~m}$ long and $1.2 \mathrm{~m}$ tall. Three historic inscriptions are undisturbed by recent graffiti. Temporal components are Historic and undefined Prehistoric (see Appendix F for description of prehistoric component).

Features: Three historic inscriptions. First is ca. $60 \mathrm{~cm}$ long and $30 \mathrm{~cm}$ tall and reads "NOV 20/16 NOV/7/20," with "N" in first half of inscription written backwards; represents two successive visits to shelter by same person. Second inscription is ca. $10 \mathrm{~cm}$ tall and $5 \mathrm{~cm}$ wide, with " $\mathrm{A}$ " drawn with long curving line like " $\mathrm{J}$ " extending from right leg, possibly historic brand or A. Justice. Third inscription is ca. $50 \mathrm{~cm} 10 \mathrm{gg}, 15 \mathrm{~cm}$ tall, and reads "SEPT/18." "S" is written backwards, suggesting that inscription dates to 1918. For further information about inscriptions, see Appendix E.

Cultural Materials Observed/Collected: None.

Shovel Test Data: None.

Assessment/Recommendations: Over $90 \%$ of the historic inscriptions appear intact; they lack associated subsurface deposits. The historic inscriptions have research potential and are judged to be potentially eligible for listing on the NRHP. However, initial field recording has exhausted the site's potential at this time, and no further work is recommended.

\section{$\underline{41 G R 516}$}

Location: Ca. $6.0 \mathrm{~km}$ ESE of U.S. Highway 84 bridge over Double Mountain Fork, and 0.7 $\mathrm{km}$ NE of confluence of Double Mountain Fork and Red Branch. 
Description: Rock art site on vertical sandstone face at base of bluff overlooking Double Mountain Fork; elevation $2240 \mathrm{ft} \mathrm{msl}$, area less than $1 \mathrm{~m}^{2}$. Single dated inscription. Temporal component is Historic.

Features: Single inscription $77 \mathrm{~cm}$ long and $26 \mathrm{~cm}$ tall reads "EARL JUSTICE JUNE 27 1115." Date is damaged by spalling and probably once read "...1915." Letters are deeply engraved and well written. For further information about inscription, see Appendix E.

Cultural Materials Observed/Collected: None.

Shovel Test Data: None.

Assessment/Recommendations: Over $90 \%$ of the site appears intact; it lacks associated subsurface deposits. The site has research potential and is judged to be potentially eligible for listing on the NRHP. However, initial field recording has exhausted the site's potential at this time, and no further work is recommended.

\section{$\underline{41 G R 517}$}

Location: Ca. $0.4 \mathrm{~km}$ SSE of confluence of Double Mountain Fork and Red Branch, and $5.9 \mathrm{~km}$ SSE of U.S. Highway 84 bridge over Double Mountain Fork.

Description: Rock art site in narrow cleft eroded from sandstone bluff of isolated mesa overlooking mouth of Red Branch; elevation $2270 \mathrm{ft} \mathrm{msl}$, area $10 \mathrm{~m}^{2}$. Few elements of aboriginal and historic rock art, historic inscriptions, and recent graffiti carved into wall of cleft. Floor of cleft is bare sandstone exposure. Temporal components are Historic and undefined Prehistoric (see Appendix F for description of prehistoric component).

Features: Two elements of historic rock art: inscription and undated group of cartoonlike figures with name written over them. Inscription is ca. $20 \mathrm{~cm}$ long and $15 \mathrm{~cm}$ tall and reads "H H 1936." Historic rock art panel is ca. $54 \mathrm{~cm}$ long and $40 \mathrm{~cm}$ tall and has line of three human figures drawn with round or ovate bodies, round heads with smiling faces, and arms represented by simple straight lines. Central figure is shown with ears; figure on far right is badly eroded. All three figures wear hats. Figure on left is tallest (ca. $40 \mathrm{~cm}$ ) and wears tall pointed hat. Central figure is $\mathrm{ca} .25 \mathrm{~cm}$ tall and has broad, short hat and shirt buttons. Next to head of figure are initials "C.D." Over heads of two right-hand figures, name "CECIL" is ca. $15 \mathrm{~cm}$ tall and $30 \mathrm{~cm}$ long. This panel probably is work of Cecil Boren, and initialed central figure is representation of Boren despite fact that initials read "C.D." and not C.B. Name "Cecil Boren" is associated with cartoon figures at another site (41GR448). Rock art must predate Boren's death in 1924. For further information about inscriptions, see Appendix E.

Cultural Materials Observed/Collected: None.

Shovel Test Data: None.

Assessment/Recommendations: Over $90 \%$ of the historic inscriptions appear intact; they lack associated subsurface deposits. The historic inscriptions have research potential and 
are judged to be potentially eligible for listing on the NRHP. However, initial field recording has exhausted the site's potential at this time, and no further work is recommended.

$\underline{41 G R 522}$

Location: Ca. $1.1 \mathrm{~km}$ ESE of intersection of U.S. Highway 84 and FM 2458, and $0.8 \mathrm{~km}$ NNE of U.S. Highway 84 bridge over Double Mountain Fork.

Description: Cemetery on small rise on upper alluvial terrace overlooking confluence of Double Mountain Fork and Salt Branch; elevation $2245 \mathrm{ft} \mathrm{msl}$, area $4225 \mathrm{~m}^{2}$. Cemetery used by community of Justiceburg is ca. $200 \mathrm{ft}$ long and $200 \mathrm{ft}$ wide. Most graves arranged in row along west side of cemetery; all graves oriented east-west. Several historic graves in cemetery, as well as numerous recent ones; approximately 76 individuals interred within 14 family plots and ca. 17 individual plots. Several graves nearly overgrown with grass. Oldest grave is dated 1911; most-recent grave is dated 1986. Temporal component is Historic.

Features: Ca. 75 historic graves, some covered with mussel shells set in concrete. Woodard Crypt dates from 1938 and may still be in use. Crypt constructed of sandstone and mortar measures ca. $10 \mathrm{ft}$ long, $10 \mathrm{ft}$ wide, and $6 \mathrm{ft}$ tall. Exterior family plot on east side of crypt contains recent burials. Grave of Belle Ira Kutch, dating to 1911, is oldest in cemetery.

Cultural Materials Observed/Collected: Gravestones, markers, and funerary offerings (wreaths, flowers, and potted plants). No collections made.

Shovel Test Data: None.

Site History: Site 41GR522, the Justiceburg Cemetery, is located in Section 25, Block 6, a tract of 640 acres which was surveyed on August 3, 1873, and patented December 27, 1873, to the Houston and Great Northern Railway Company (Texas. General Land Office 1873a). Within seven years, Section 25 and a number of other sections had been conveyed to the New York and Texas Land Company, Ltd. (Texas. General Land Office 1873b), and that company leased a total of 137 surveys for grazing purposes to J. W. Mooar Brothers (Garza County Deed Record 3:29-32). Fifteen years later, the land became the subject of a dispute between individuals who held interest in the New York and Texas Land Company and the Houston and Texas Central Railway Company. In December 1895, when the two parties divided the land, Section 25, Block 6, became one of the tracts conveyed to Thomas R. White, Jr. of Union County, New Jersey (Texas. General Land Office 1873b).

White held Section 25 until March 7, 1903, when he sold it to Jeff D. Justice for $\$ 1440.00$. One note was signed by Justice at Leforest, Texas, the post office which the Tuffings had established on Section 10, Block 6, their homestead tract. Justice then held Section 25 as grazing land unt1l 1910 when he filed a plat for the town of Justiceburg which covered all of the Section north of the Double Mountain Fork of the Brazos River (Garza County Map and Plat Record №. 1:14).

Although a cemetery was not designated on the plat, site 4IGR522 appears to fall within Block 1, which was left unsubdivided into lots. No designation of a Justiceburg 
Cemetery has been located in the Garza County deed records, but such a dedication must have occurred soon after the filing of the town plat, for a burial is known to have occurred in 1911. The cemetery has been in continual use since that date.

Assessment/Recommendations: Justiceburg Cemetery, established ca. 1911, contains a number of historic Anglo and Hispanic graves, including those of individuals who are important figures in the history of the Justiceburg area. Over $90 \%$ of the site appears intact; it contains a stone vault, gravestones and markers, and subsurface deposits. The site has an excellent research potential and is judged to be potentially eligible for listing on the NRHP according to Criteria $B$ and $D$. It is recommended that, because the cemetery is increasingly likely to become a target for vandalism, the site be protected by fencing and/or some other method. The cemetery should be inventoried and mapped, and all graves located and plotted. It is further recommended that gravestones and markers be photographed and that research be done on the establishment of the cemetery.

$\underline{41 G R 525}$

Location: Ca. $2.3 \mathrm{~km} \mathrm{NE}$ of U.S. Highway 84 bridge over Sand Creek, and $0.1 \mathrm{~km}$ ESE of confluence of Double Mountain Fork and Sand Creek.

Description: Rock art site on vertical sandstone face on bluff just below canyon rim overlooking Double Mountain Fork; elevation $2220 \mathrm{ft} \mathrm{msl}$, area $20 \mathrm{~m}^{2}$. Two historic inscriptions which have no date, but lettering style is indicative of late 1800s or early 1900s. Rockshelter within $2 \mathrm{~m}$ of inscriptions has no cultural evidence. Temporal component is Historic.

Features: Three historic Inscriptions; one ca. $12 \mathrm{~cm}$ long and $2 \mathrm{~cm}$ tall reads "J. MELZA." A second is ca. $20 \mathrm{~cm}$ long and $5 \mathrm{~cm}$ tall and reads "HOLLIS AND VERDA DRAKE." "HHL" is also inscribed with the letters connected. For further information on inscriptions, see Appendix E.

Cultural Materials Observed/Collected: None.

Shovel Test Data: Five shovel tests in adjacent rockshelter yielded only pack rat midden debris. Soll depth was ca. $40 \mathrm{~cm}$.

Assessment/Recommendations: Over 90\% of the historic inscriptions appear intact; they probably lack associated subsurface deposits. The historic inscriptions have research potential and are judged to be potentially eligible for listing on the NRHP. However, initial field recording has exhausted the site's potential at this time, and no further work is recommended.

\section{GR526}

Location: Ca. $2.3 \mathrm{~km} \mathrm{NE}$ of U.S. Highway 84 bridge over Sand Creek, and $0.1 \mathrm{~km}$ ESE of confluence of Double Mountain Fork and Sand Creek. 
Description: Rock art site on large vertical sandstone face at base of bluff overlooking Double Mountain Fork; elevation $2240 \mathrm{ft} \mathrm{msl}$, area $20 \mathrm{~m}^{2}$. Panel of recent and historic inscriptions ca. $10 \mathrm{~m}$ long and $2 \mathrm{~m} \mathrm{high.} \mathrm{Only} \mathrm{one} \mathrm{inscription} \mathrm{is} \mathrm{dated} \mathrm{(1897);}$ however, other inscriptions are considered historic by virtue of lettering style. Temporal component is Historic.

Features: Inscription with historic date is ca. $33 \mathrm{~cm}$ long and $9 \mathrm{~cm}$ tall and reads "W. L. Groves 1897," with "s" written backwards and a stylized "r" which looks like a "y.". Other inscriptions that may be historic are "HHL," written with letters connected, and "MAY 12 nO RaiN" surrounded by rectangular outline. "98" outside box may indicate year 1898 but may not be associated with inscription. "KELLY \& ROY" also appears without an associated date. O. B. Kelly and W. Roy were cowboys with the OS Ranch. "ORA \& EMMA" also appears without dates. For further information on inscriptions, see Appendix E.

Cultural Materials Observed/Collected: None.

Shovel Test Data: None.

Assessment/Recommendations: Over $90 \%$ of the site appears intact; it lacks associated subsurface deposits. The site has research potential and is judged to be potentially eligible for listing on the NRHP. However, initial field recording has exhausted the site's potential at this time, and no further work is recommended.

$\underline{41 G R 528}$

Location: Ca. $0.7 \mathrm{~km} \mathrm{~N}$ of U.S. Highway 84 bridge over Sand Creek, and $1.7 \mathrm{~km} \mathrm{SW}$ of confluence of Double Mountain Fork and Sand Creek.

Description: Historic grave/buffalo hunters camp(?) on erosional remnant terrace above alluvial terrace of Sand Creek; elevation 2240-2260 ft msl, area 10,000 $\mathrm{m}^{2}$. First discovered by Emmett Shedd, who noted historic grave and scatter of historic artifacts. Current investigations recorded site and added prehistoric component. Grave is situated on erosional remnant terrace, while historic artifacts are located on alluvial terrace below in scatter ca. $6 \mathrm{ft}$ in diameter. Sparseness of historic artifacts may be due to thorough surface collection by Shedd. Few historic materials in vicinity of grave. Association of artifact scatter and historic grave is not certain. Temporal components are Historic and undefined Prehistoric (see Appendix F for description of prehistoric component).

Features: Grave is oulined by rectangular arrangement of sandstone cobbles and slabs and measures ca. $6 \times 3 \mathrm{ft}$. Marker at head of grave is large undressed slab of sandstone with hand-carved inscription reading "A. W. McCormick of St. Louis Mi.... Died Jan 7 th AD. 1878. AGE 36 Year." Cracks are developing in sandstone, and inscription is somewhat eroded. "36" could be " 86, " although Shedd relates story that McCormick was buried by his father, in which case inscription probably would read "36."

Cultural Materials Observed/Collected: Hole-in-top tin cans, fragments of thick brown bottle glass, miscellaneous fragment of metal, and fragments of light green bottle glass with embossed lettering. One fragment reads "JUNE - 9 - 68." Shedd collected .45-70 primers, .44-caliber center-fire primers, .44-caliber center-fire cartridge case, 
.44-caliber lead slug, fragments of lead sprue from casting of bullets, square nails, and fragment from bowl of small clay pipe. No collections made.

Shovel Test Data: None.

Site History: The ownership history of Section 13, Block 6, on which site 41 GR528 is located is identical to the history of site 41GR460. This section was first leased for grazing in 1880. A. W. McCormick's grave is dated 1878, while the large-caliber cartridges, primers, and slugs found in the artifact scatter are typical of those used by buffalo hunters in the mid 1870s (Gard 1959:98; Barnes 1980:78, 114-117) and found at Adobe Walls (Baker and Harrison 1986). Buffalo hunters were st1ll active in Garza County during this period (Gard 1959:251), and it is possible that the Mooar, Woody, and/or Rumph outfits could be responsible for this camp (see Chapter 9).

Assessment/Recommendations: Although some major buffalo hide trading posts like Adobe Walls are known through archeological studies, small buffalo hunting camps like 41GR528 remain poorly known. A camp of this type in the Texas Panhandle as depicted in 1874 photographs (Gard 1959:1llustrations 15 and 16a) would be expected to have few materlal remains. Such rare and ephemeral sites are important in documenting this period.

Less than $50 \%$ of the historic component appears intact; it contains features and probable subsurface deposits. The historic component has an excellent research potential and is judged to be potentially eligible for listing on the NRHP according to Criteria $A$ and D. It is recommended that full-scale mitigation procedures be undertaken due to the high likelihood that greater public use of the area will result in vandalism to the grave. These procedures should include archeological removal and relocation of the interment and mapping and collection of the artifact scatter. Emmett Shedd's collection from this site should be documented. Also, further research on buffalo hunting in the area should be conducted utilizing records at Texas Tech University in Lubbock and tapes and other materials collected by Mrs. Surm of Post, Texas. Preliminary attempts to identify A. W. McCormick by examining the 1850 and 1860 federal censuses for St. Louis and other documents should be continued.

\section{$\underline{41 G R 530}$}

Location: Ca. $4.1 \mathrm{~km}$ SSE of U.S. Highway 84 bridge over Double Mountain Fork, and 0.5 $\mathrm{km}$ NNW of U.S. Highway 84 bridge over Sand Creek.

Description: Possible housesite on slight ridge on upper alluvial terrace over Sand Creek; elevation $2240 \mathrm{ft} \mathrm{msl}$, area $4500 \mathrm{~m}^{2}$. Sparse scatter of historic debris, with two concentrations, each measuring $165 \times 160 \mathrm{ft}$, below erosional remnants on ridge may date to 1930s. Materials shifted by sheetwash and erosion. Temporal component is Historic.

Features: None.

Cultural Materials Observed/Collected: Wood-burning stove parts; fragments of manganese-bleached, green, and clear glass; whiteware fragments; tin cans; barbed wire; and miscellaneous metal fragments. No collections made. 
Shovel Test Data: None.

Site History: For a history of Section 13 on which site 41 GR530 is located, see the site history for 41GR460.

Assessment/Recommendations: A county history (Women's Division of Post Chamber of Commerce $\left.n_{\bullet} d_{\circ}: 90\right)$, which includes a memoir by Mrs. Henry Key, includes references to a gas station and house at Sand Creek during the time sand and gravel were hauled from the area. Mrs. Key also refers to the old Cameron Justice House in the same area which was occupied ca. 1930 by the Keys and Oliver H. Curtis. However, no information was located during the current investigations which provided a conclusive identification of that age or function of site 41 GR530 or its association, if any, with 41 GR460. Less than $50 \%$ of the site appears intact; it may lack subsurface deposits. The site has an unknown research potential but is judged to be potentially eligible for listing on the NRHP according to Criterion D. Because of the lack of substantive information about the site, it is recommended that an attempt be made to locate a member of the Justice or Key families who can identify 41GR530 and provide information about its functional relationship with 41 GR460.

\section{$\underline{41 G R 536}$}

Location: Ca. $2.4 \mathrm{~km}$ NNE of U.S. Highway 84 bridge over Sand Creek, and $0.5 \mathrm{~km}$ NNW of confluence of Double Mountain Fork and Sand Creek.

Description: Rock art site in small concavity eroded from vertical rock face on bluff overlooking confluence of Double Mountain Fork and unnamed drainage north of Sand Creek; elevation $2240 \mathrm{ft} \mathrm{msl}$, area $20 \mathrm{~m}^{2}$. Three historic inscriptions with dates. Temporal component is Historic.

Features: Three inscriptions. First is ca. $34 \mathrm{~cm}$ long and $18 \mathrm{~cm}$ tall and reads "HOWARD PENN 11-16-35 FT. WORTH, TEX" surrounded by rectangular outline. Second is ca. 47 $\mathrm{Cm}$ long and $13 \mathrm{~cm}$ tall and reads "J A FERGUSON OCT.31.26. POST. TEX," with "J" written in script. Third inscription is ca. $54 \mathrm{~cm}$ long and $25 \mathrm{~cm}$ tall and has "C J Leininger Justiceburg Texas November 25th 1918" written in script. For further information on inscriptions, see Appendix E.

Cultural Materials Observed/Collected: None.

Shovel Test Data: None.

Assessment/Recommendations: Over $90 \%$ of the site appears intact; it lacks associated subsurface deposits. The site has research potential and is judged to be potentially eligible for listing on the NRHP. However, initial field recording has exhausted the site's potential at this time, and no further work is recommended.

\section{GR537}

Location: Ca. $2.9 \mathrm{~km}$ NNE of U.S. Highway 84 bridge over Sand Creek, and $4.1 \mathrm{~km}$ ESE of U.S. Highway 84 bridge over Double Mountain Fork. 
Description: Rock art site on vertical rock face on bluff overlooking unnamed drainage north of Sand Creek just below upland margin rim; elevation $2250 \mathrm{ft}$ msl, area less than $1 \mathrm{~m}^{2}$. Single inscription with historic date. Temporal component is Historic.

Features: Inscription ca. $25 \mathrm{~cm}$ long and $15 \mathrm{~cm}$ tall reads "Newton Renfroe 1935." For further information about inscription, see Appendix E.

Cultural Materials Observed/Collected: None.

Shovel Test Data: None.

- Assessment/Recommendations: Over $90 \%$ of the site appears intact; 1t lacks associated subsurface deposits. The site has research potential and is judged to be potentially eligible for listing on the NRHP. However, initial field recording has exhausted the site's potential at this time, and no further work is recommended.

\section{$\underline{41 G R 545}$}

Location: Ca. $5.0 \mathrm{~km}$ ESE of intersection of U.S. Highway 84 and FM 2458 , and $0.8 \mathrm{~km}$ NNW of confluence of Double Mountain Fork and Sand Creek.

Description: Rock art site on tall vertical sandstone face located beneath large overhang on bluff overlooking Double Mountain Fork; elevation 2260-2280 ft msl, area 100 $\mathrm{m}^{2}$. Rock face is ca. $20 \mathrm{~m}$ long and $5 \mathrm{~m}$ high; bedrock bench below rock face is ca. $2 \mathrm{~m}$ wide. Large number of historic inscriptions carved into rock face, with one possible aboriginal petroglyph. Rock art occurs in many panels over area ca. $20 \mathrm{~m}$ long and $2 \mathrm{~m}$ high. Many inscriptions are dated, and others are written in historic lettering style. Two probable brand marks. Inscriptions are somewhat damaged by recent graffiti. Temporal components are Historic and undefined Prehistoric (see Appendix F for description of prehistoric component).

Features: Twenty inscriptions on site which are considered historic or include historic dates: "JEF July 7 1901," "JAN," "JMB 1887" (surrounded by rectangular outline), "W ROY 1887," "R. T... 1898," "JAN.13 1898," "I C EVANS APRiL 16/1911" (with "S" written backwards), "CJL" is nearby and probably associated with the date "11-20-18," "H.D.R 1925," "GENNEVA (JA?) JULY 4, 1927," "GP JULY 4 1927," "MED 1931," "A B 1935" (written over with recent graffiti and difficult to read), "Nannie," "Pearl," "WR," "WVR," and "Roy."

Two brand marks are "OS" (written sideways with "S" backwards) and "A-B" (written with continuous horizontal line through both letters). Isolated date inscriptions include "1898," "1925," "1936," and "1938." For further information on inscriptions, see Appendix E.

Cultural Materials Observed/Collected: None.

Shovel Test Data: None.

Assessment/Recommendations: Over $90 \%$ of the historic inscriptions appear intact; they lack associated subsurface deposits. The historic inscriptions have research potential and 
are judged to be potentially eligible for listing on the NRHP. However, initial field recording has exhausted the site's potential at this time, and no further work is recommended.

\section{$\underline{41 G R 550}$}

Location: Ca. $4.5 \mathrm{~km}$ ESE of intersection of U.S. Highway 84 and FM 2458 , and $1.2 \mathrm{~km}$ NW of confluence of Double Mountain Fork and Sand Creek.

Description: Rock art site on vertical rock face on bluff above head of small drainage overlooking Double Mountain Fork; elevation $2230 \mathrm{ft} \mathrm{msl}$, area less than $1 \mathrm{~m}^{2}$. Single inscription with historic date which is eroded so that exact year is not known. Temporal component is Historic.

Features: Inscription reads "LMJ... 11/9 1...." Fragments of rock have spalled off, so that upper part of " $L$ " and most of fourth letter are missing. Year is eroded and could represent 1910, 1916, or 1918. For further information about inscription, see Appendix E.

Cultural Materials Observed/Collected: None.

Shovel Test Data: None.

Assessment/Recommendations: Over $90 \%$ of the site appears intact; it lacks associated subsurface deposits. The site has research potential and is judged to be potentialiy eligible for listing on the NRHP. However, initial field recording has exhausted the site's potential at this time, and no further work is recommended.

\section{GR552}

Location: Ca. $2.7 \mathrm{~km}$ NNE of U.S. Highway 84 bridge over Sand Creek, and $3.3 \mathrm{~km}$ ESE of U.S. Highway 84 bridge over Double Mountain Fork.

Description: Rock art site on vertical rock face on bluff overlooking Double Mountain Fork; elevation $2230 \mathrm{ft} \mathrm{msl}$, area less than $1 \mathrm{~m}^{2}$. Single inscription with historic date. Temporal component is Historic.

Features: Inscription is "C J Leininger Nov. 9. 18" written in script, with ends of "L" and "N" trailing downward in long curving arcs. For further information, see Appendix E.

Cultural Materials Observed/Collected: None.

Shovel Test Data: None.

Assessment/Recommendations: Over $90 \%$ of the site appears intact; it lacks assoclated subsurface deposits. The site has research potential and is judged to be potentially eligible for listing on the NRHP. However, initial field recording has exhausted the site's potential at this time, and no further work is recommended. 


\section{GR553}

Location: Ca. $4.4 \mathrm{~km}$ ESE of intersection of U.S. Highway 84 and FM 2458, and $1.4 \mathrm{~km}$ NE of confluence of Double Mountain Fork and Sand Creek.

Description: Rock art site on vertical rock face high on bluff overlooking Double Mountain Fork; elevation $2260 \mathrm{ft} \mathrm{msl}$, area $9.5 \mathrm{~m}^{2}$. Rock face is ca. $7 \mathrm{~m}$ long with ledge below it ca. $1 \mathrm{~m}$ wide. Four panels of historic inscriptions and panel of historic rock art. Temporal component is Historic.

Features: Five panels, four containing one or more inscriptions, while fifth has historic rock art. First panel is $\mathrm{ca} .75 \mathrm{~cm}$ long and ca. $16 \mathrm{~cm}$ tall, with inscription which reads "M. T. 7/15 1901."

Second panel is ca. $115 \mathrm{~cm}$ long and $60 \mathrm{~cm}$ tall and contains six inscriptions, five by same person. First reads "ALT 4/21 1901" and is written above rest of inscriptions, which are arranged horizontally with increasing dates. Next three inscriptions read "A.L.T. 1904," "A.L.T. 3/'08," and "6/1910 A.L.T. 3/1911," with last inscription representing two visits. Final inscription reads "F.B.T. 1904."

Third panel is ca. $45 \mathrm{~cm}$ long and $35 \mathrm{~cm}$ tall and reads "Bruce Jones 11. 9. 56. GrAND. R. MicHiGA..." (last letter spalled off). Tail of "s" doubles back to partially surround date. First letter of each word is ca. twice size of others.

Fourth panel is ca. $70 \mathrm{~cm}$ long and $35 \mathrm{~cm}$ tall. It reads "EArL Stevens. 11.9. 18. WAUSE... Ohio" (latter part of city name too faint to read). First word is written with initial letter twice size of others; "Stevens" written in script with end of "s" trailing back to underscore word and ending in curved triangle filled with hatch marks.

Fifth panel is ca. $51-\mathrm{cm}-\mathrm{tall}$ and $38-\mathrm{cm}-$ wide profile portrait of cowboy. Figure wears 10-gallon hat and western-style shirt. Hair, eyes (with pupils), eyebrows, nostrils, and smoldering cigarette are depicted. For further information about inscriptions, see Appendix E.

Cultural Materials Observed/Collected: None.

Shovel Test Data: None.

Assessment/Recommendations: Over 90\% of the site appears intact; it lacks associated subsurface deposits. The site has research potential and is judged to be potentially eligible for listing on the NRHP. However, initial field recording has exhausted the site's potential at this time, and no further work is recommended.

\section{GR556}

Location: Ca. $3.5 \mathrm{~km}$ ESE of intersection of U.S. Highway 84 and FM 2458 , and $2.5 \mathrm{~km} \mathrm{E}$ of U.S. Highway 84 bridge over Double Mountain Fork. 
Description: Rock art site on vertical sandstone face on bluff overlooking Double Mountain Fork; elevation $2250 \mathrm{ft} \mathrm{msl}$, area $3 \mathrm{~m}^{2}$. Two historic inscriptions and historic rock art. Temporal component is Historic.

Features: Two inscriptions and element of rock art. First inscription is ca. $28 \mathrm{~cm}$ long and $15 \mathrm{~cm}$ tall and reads "C. J. L. 10/20/18." Second inscription reads "NJ," with hook of "J" curving under "N." Surrounding initials is drawing of horned owl sitting on stump, with body of owl in profile and head facing front. Within stump is inscription "5/19/27," with "7" written outside the outline. Element of rock art is rattlesnake ca. 59 $\mathrm{cm}$ long and $15 \mathrm{~cm}$ tall with diamonds on back and rattles on tail. Head is viper shape with forked tongue. For further information on inscriptions, see Appendix E.

Cultural Materials Observed/Collected: None.

Shovel Test Data: None.

Assessment/Recommendations: Over $90 \%$ of the site appears intact; it lacks associated subsurface deposits. The site has research potential and is judged to be potentially eligible for listing on the NRHP. However, initial field recording has exhausted the site's potential at this time, and no further work is recommended.

\section{GR557}

Location: Ca. $2.8 \mathrm{~km}$ ESE of intersection of U.S. Highway 84 and FM 2458, and $1.8 \mathrm{~km} \mathrm{E}$ of U.S. Highway 84 bridge over Double Mountain Fork.

Description: Rock art site on vertical rock face at base of bluff overlooking Double Mountain Fork; elevation $2240 \mathrm{ft} \mathrm{msl}$, area uncertain. Numerous inscriptions, two with historic dates and one with possible historic name. Other inscriptions are recent. Temporal component is Historic.

Features: Two inscriptions with historic dates: one ca. $25 \mathrm{~cm}$ long and $8 \mathrm{~cm}$ tall read "W B W 1918"; other ca. $20 \mathrm{~cm}$ long and $20 \mathrm{~cm}$ tall reads "R.B. 1936." Another inscription reads "VADA JUSTICE"; Justice family is historically known in Justiceburg area. For further information on inscriptions, see Appendix E.

Cultural Materials Observed/Collected: None.

Shovel Test Data: None.

Assessment/Recommendations: Over $90 \%$ of the site appears intact; it lacks associated subsurface deposits. The site has research potential and is judged to be potentially eligible for listing on the NRHP. However, initial field recording has exhausted the site's potential at this time, and no further work is recommended.

\section{$41 \mathrm{GR} 558$}

Location: Ca. $2.7 \mathrm{~km}$ ESE of intersection of U.S. Highway 84 and FM 2458, and $1.9 \mathrm{~km} \mathrm{E}$ of U.S. Highway 84 bridge over Double Mountain Fork. 
Description: Rock art site on vertical sandstone face on bluff overlooking Double Mountain Fork; elevation 2240 ft msl, area uncertain. Several inscriptions, two with historic dates and three more with names of historically known persons or written in historic lettering style. Site is not far from Jeff Justice Homestead (41GR474). Temporal component is Historic.

Features: Five historic inscriptions. First is ca. $44 \mathrm{~cm}$ long and $18 \mathrm{~cm}$ tall and reads "JEFF JUSTICE." Second is ca. $83 \mathrm{~cm}$ long and $7 \mathrm{~cm}$ tall and reads "J. J. J. MAR. 7 1909." Third reads "JERRY Odom," but no date is associated. Fourth is ca. $44 \mathrm{~cm} 10 \mathrm{lg}$ and $15 \mathrm{~cm}$ tall and reads "10-10-43 I. W. GR...IS." Fifth Inscription reads "WALLACE," but no date is associated. For further information on inscriptions, see Appendix E.

Cultural Materlals Observed/Collected: None.

Shovel Test Data: None.

Assessment/Recommendations: Over 90\% of the site appears intact; it lacks associated subsurface deposits. The site has research potential and is judged to be potentially eligible for listing on the NRHP. However, initial field recording has exhausted the site's potential at this time, and no further work is recommended.

\section{GR559}

Location: Ca. $5.2 \mathrm{~km}$ ESE of intersection of U.S. Highway 84 and Fm 2458, and $0.6 \mathrm{~km}$ NNE of confluence of Double Mountain Fork and Sand Creek.

Description: Rock art site in rockshelter eroded from bluff overlooking unnamed side drainage north of Sand Creek; elevation 2240-2250 ft msl, area $30 \mathrm{~m}^{2}$. Shovel testing in shelter revealed prehistoric cultural deposits. Above mouth of shelter are two historic inscriptions on same rock face ca. $10 \mathrm{~m}$ apart. Temporal components are Historic and undefined Prehistoric (see Appendix F for description of prehistoric component).

Features: Two historic inscriptions. One ca. $29 \mathrm{~cm}$ long and $5 \mathrm{~cm}$ tall reads "C.J.L. 11-25-18." Other is ca. $35 \mathrm{~cm}$ long and $6 \mathrm{~cm}$ tall and reads "E. V. B. 10-13-26." For further information about inscriptions, see Appendix E.

Cultural Materials Observed/Collected: None.

Shovel Test Data: None.

Assessment/Recommendations: Over 90\% of the historic inscriptions appear intact; they lack associated subsurface deposits. The historic inscriptions have research potential and are judged to be potentially eligible for listing on the NRHP. However, initial field recording has exhausted the site's potential at this time, and no further work is recommended. 
Location: Ca. $4.8 \mathrm{~km}$ WSW of intersection of Garza/Kent county line and Double Mountain Fork, and $2.9 \mathrm{~km}$ NW of confluence of Double Mountain Fork and Little Grape Creek.

Description: Housesite on rise in uplands ca. $600 \mathrm{~m}$ west of unnamed drainage east of Cat Hollow; elevation $2320 \mathrm{ft} \mathrm{msl}$, area $2500 \mathrm{~m}^{2}$. Site has windmill and concrete tanks, chimney foundation, scatter of bricks, and scatter of domestic debris. Area has been chain-cleared and bladed, so little of cultural deposit is left intact. Windmill and tanks could be recent. Site probably is related to historic dump sites 41 GR273 and 41 GR350. Temporal component is Historic.

Features: Chimney foundation measuring ca. $4 \times 2$ ft with two layers of sandstone blocks and three layers of bricks on top. Both red and tan bricks used; red ones are labeled "LPB CO," while tan ones are labeled "DENTON FIREBRICK." Debris scatter around foundation.

Cultural Materials Observed/Collected: Fragments of glass, crockery, whiteware, and bricks. No collections made.

Shovel Test Data: None.

Site History: History of site 41GR565, which is located in Section 95, Block 5, 1s identical to that of sites $41 \mathrm{GR} 273$ and $41 \mathrm{GR} 350$.

Assessment/Recommendations: Less than $10 \%$ of the site appears intact; it may lack subsurface deposits. The site has no research potential and is judged to be not eligible for listing on the NRHP. No further work is recommended.

\section{GR567}

Location: Ca. $2.2 \mathrm{~km}$ NNE of U.S. Highway 84 bridge over Sand Creek, and $4.1 \mathrm{~km}$ ESE of U.S. Highway 84 bridge over Double Mountain Fork.

Description: Rock art site in rockshelter eroded from sandstone bluff overlooking Double Mountain Fork; elevation $2240 \mathrm{ft} \mathrm{ms}$, area $19.25 \mathrm{~m}^{2}$. Shelter is ca. $5.5 \mathrm{~m}$ wide and $3.5 \mathrm{~m}$ deep; floor is covered with sand but has no cultural deposits. Shelter has two elements of rock art, one aboriginal and one historic. Temporal components are Historic and undefined Prehistoric (see Appendix F for description of prehistoric component).

Features: Historic inscription ca. $92 \mathrm{~cm}$ wide and $60 \mathrm{~cm}$ wide reads "P C BENNETT BLUFFDALE TEXAS JAN 5 1923." "N"s are written backwards.

Cultural Materlals Observed/Collected: None.

Shovel Test Data: One negative shovel test indicated soll depth of ca. $26 \mathrm{~cm}$.

Assessment/Recommendations: Over 90\% of the historic inscriptions appear intact; they lack associated subsurface deposits. The historic inscriptions have research potential and 
are judged to be potentially eligible for listing on the NRHP. However, initial field recording has exhausted the site's potential at this time, and no further work is recommended.

KENT COUNTY SITES

$\underline{41 K T 42}$

Location: Ca. $1.4 \mathrm{~km}$ SE of confluence of Double Mountain Fork and Grape Creek, and $1.1 \mathrm{~km} \mathrm{~S}$ of intersection of Garza/Kent county line and Double Mountain Fork.

Description: Cattle company line camp site on narrow alluvial terrace at base of bluff overlooking Grape Creek; elevation 2140-2160 ft msl, area 12,000 $\mathrm{m}^{2}$. Historic housesite within area of prehistoric artifact scatter consists of remains of cabin with associated scatter of historic artifacts and possible garden plot. Artifact scatter concentrated around cabin and extends down terrace to creek. Possible garden plot visible on aerial photographs as roughly rectangular area with less vegetation west of cabin. Recent picnickers knocked down cabin walls. Site also has been surface collected and disturbed by core drilling and heavy machinery traffic. Site is known historically to have been occupied by Ed Scott, a cowboy employed by OS Ranch. Temporal components are Historic and late Archaic-Late Prehistoric (see Appendix F for description of prehistoric components).

Features: Remnant of cabin is rectangular structure of dry-laid, undressed sandstone slabs measuring ca. $20 x 14 \mathrm{ft}$, with wall ca. $4 \mathrm{ft}$ tall at highest point. At north end of structure is partially collapsed firebox $7 \mathrm{ft} 3$ inches long and ca. $1 \mathrm{ft} 6$ inches wide. Stone on inside of firebox is reddened from heating. No doorway or windows indicated in remaining courses of walls.

Cultural Materials observed/Collected: Cartridge cases; fragments of manganesebleached, clear, green, and amber glass; Albany slip crockery fragments; whiteware fragments; bone fragments; horseshoe nails; square nails; wooden beams; metal buttons; hinged stein lid; and other miscellaneous fragments. Owner Billy Huddleston reports that Alexander of GRC visited site and collected clay pipe, cartridge cases, and buttons. Four items collected (see Appendices A and B).

Shovel Test Data: None.

Site History: Site 41KT42 is located in Section 56, Block 5, a tract composed of 59.5 acres in Garza County and 580.5 acres in Kent County (Texas. General Land Office $1900 \mathrm{~b}$ ). In 1882, H. T. Cornelius, who was a business partner of J. W. Mooar (Garza County Deed Record 3:29-32), began to make payments on Section 56. He held the property until December 14, 1886, when he sold Sections 56,58, and 60 to A. J. Long of Nolan County. Long and his brother, F. M., then apparently used the three sections purchased from Cornelius as a core grazing land and leased additional sections in Blocks 5 and 6 from the General Land Office (Kent County Deed Record 1:309-310; Deed Record 5:395-396).

The Longs used the land in Kent and Garza counties for grazing purposes until they sold a total of 26,411 acres to a partnership consisting of $W$. E. Connell, who bought a 
one-half interest, and John Scharbauer and E. W. Clark, who each bought a one-quarter interest. Scharbauer then sold his interest to Connell on November 26, 1909, and E. W. Clark followed suit on March 14, 1913 (Kent County Deed Record 8:199-202; Deed Record 14: 78-81; Deed Record 16:45-48). Connell held the ranch until he died in about 1943 and left the land to two daughters. On March 22, 1954, the heirs decided to partition the land, and Connell's daughter, Blanche, received the 13,559.2-acre tract which included Section 56, Block 5 (Kent County Deed Record 32:141; Deed Record 74:332-333). Connell heirs owned the land until ca. 1970 when it was acquired by Billy Huddleston.

Assessment/Recommendations: Site $41 \mathrm{KT} 2$ is the location of the site of a log house which may have been constructed as a cowboy line camp as early as 1882 when cattleman H. T. Cornelius owned the section on which the site is located. It very likely was utilized by cowboys until well into the twentieth century. It is most often associated with Ed Scott, although it is not clear whether informants are referring to Ed Scott, Sr., who began working for the Longs in 1884 (McCrary 1970:8) and managed the Llano Ranch, or Ed Scott, Jr., his son, who came to Garza County in 1889 and worked for the OS for more than 60 years (The Post Dispatch, September 12, 1957:1). The site probably is one of the two longest continually Anglo-occupied localities in the project area (see also 41KT84) and is associated with locally significant historical figures. Over $50 \%$ of the historic component appears intact; it may contain subsurface deposits. The historic component has an excellent research potential and is judged to be potentially eligible for listing on the NRHP according to Criteria $A, B$, and $D$. It is recommended that the site be mapped and tested, that further historical research be done concerning its occupation, that artifacts from the site be analyzed to aid in assigning a date of initial occupation, and that the artifacts be compared with those from dugouts in the project area, especially 41 KT84 with which it may be contemporaneous.

\section{$\underline{41 K T 50}$}

Location: Ca. $3.5 \mathrm{~km}$ SSW of confluence of Double Mountain Fork and South Sage Creek, and $3.1 \mathrm{~km}$ ESE of confluence of Double Mountain Fork and Little Grape Creek.

Description: Rock art site in overhang shelter on bluff overlooking Grape Creek; elevation $2260 \mathrm{ft} \mathrm{msl}$, area $47.5 \mathrm{~m}^{2}$. Shelter formed by erosion and spalling of lighter, softer sandstone from beneath more-resistant stratum of ferruginous sandstone is ca. $9.5 \mathrm{~m}$ long and $5 \mathrm{~m}$ deep. Floor of shelter covered with thin eolian sands and roof spalls; shovel testing found no cultural deposits. Several aboriginal rock art panels and single historic inscription. Temporal components are Historic and undefined Prehistoric (see Appendix F for description of prehistoric component).

Features: Historic inscription ca. $41 \mathrm{~cm}$ long and $12 \mathrm{~cm}$ tall reads "J. C. Smith -E BRND 1886 JAN.3." Brand mark is drawn with bar contiguous with middle bar of "E." For further information about inscription, see Appendix E.

Cultural Materials Observed/Collected: None.

Shovel Test Data: One negative shovel test indicated soil depth of ca. $35 \mathrm{~cm}$. 
Assessment/Recommendations: Over $90 \%$ of the historic inscription appears intact; it lacks associated subsurface deposits. The historic inscription has research potential and is judged to be potentially eligible for listing on the NRHP. However, initial field recording has exhausted the site's potential at this time, and no further work is recommended.

\section{$\underline{41 K T 54}$}

Location: Ca. $2.5 \mathrm{~km}$ SSE of confluence of Double Mountain Fork and Grape Creek, and $3.2 \mathrm{~km}$ ESE of confluence of Double Mountain Fork and Little Grape Creek.

Description: Rock art site on vertical rock face at base of bluff on east side of Grape Creek by small spring-fed drainage; elevation $2260 \mathrm{ft} \mathrm{msl}$, area $45 \mathrm{~m}^{2}$. Large panel with numerous inscriptions, four with historic dates. Temporal component is Historic.

Features: Four historic inscriptions on panel ca. $10 \mathrm{~m} \mathrm{long}$ and $3 \mathrm{~m}$ high. First is ca. $180 \mathrm{~cm}$ long and $35 \mathrm{~cm}$ tall and reads "Adam G McCoy Dec the 24th 1885." Second is ca. $105 \mathrm{~cm}$ long and $35 \mathrm{~cm}$ tall and reads "MAUD DAVIS, 19 AND DELLA STELL 15 FEB. 23, 1908." Third inscription reads "EVA DAVIS 11 WILLE STELL 14 JEP STELL 8 AGNES 9/24," with year written so that "2" forms upper part of "4." Fourth inscription reads "P. M. Esqueda 10/37" written in small script. For further information about inscriptions, see Appendix E.

Cultural Materials Observed/Collected: None.

Shovel Test Data: None.

Assessment/Recommendations: Over $90 \%$ of the site appears intact; it lacks associated subsurface deposits. The site has research potential and is judged to be potentially eligible for listing on the NRHP. However, initial field recording has exhausted the site's potential at this time, and no further work is recommended.

\section{$\underline{41 \mathrm{KT} 58}$}

Location: Ca. $3.2 \mathrm{~km}$ SSE of confluence of Double Mountain Fork and Grape Creek, and $3.5 \mathrm{~km}$ ESE of confluence of Double Mountain Fork and Little Grape Creek.

Description: Homestead site on upland margin on east side of Grape Creek; elevation 2280-2310 ft msl, area $48,000 \mathrm{~m}^{2}$. Historic residence with remains of house, two cisterns, and possible barn, with trash dump located nearby downslope. Structural remains are on upper edge of site, while dump is on canyon rim. Small drainage runs from house to dump and down into Grape Creek. Artifacts scattered across site with concentration in dump area. Site has been bulldozed; structural remains found in berm measuring $\mathrm{ca}$. $70 \mathrm{x} 7 \mathrm{ft}$. Dirt road runs through site near house complex. Site dates from 1920s or 1930s to 1950s. Temporal component is Historic. 
Features: Two cisterns and pile of sandstone foundation slabs. One cistern is brick lined with cement. Second concrete-lined cistern has metal band around top. Top of brick cistern has been placed on second cistern. Both cisterns partially filled with rubble. Pile of sandstone slabs ca. $25 \mathrm{ft}$ in diameter is probably remains of outbuilding, possibly barn.

Cultural Materials Observed/Collected: Sanitary-type tin cans, paint cans, motor oll cans, whiteware fragments, fragments of glass bottles and jars, buckets, machinery parts, license plates (1928 and 1958), coffee pot, tires, stove parts, bricks, metal plate, automobile body (ca. 1920s), and miscellaneous metal fragments. No collections made.

Shovel Test Data: None.

Site History: Site 41KT58 is located in Section 57, Block 5, a 640-acre tract comprised of 56.5 acres in Garza County and 583.5 acres in Kent County. The land was surveyed on August 2, 1873, and patented to the Houston and Great Northern Railway Company on December 27, 1873 (Texas. General Land Office 1873a). By November 1880, Section 57 and a number of other sections had been conveyed to the New York and Texas Land Company, Ltd. (Texas. General Land Office 1873b), and that company leased a total of 137 surveys for grazing purposes to J. W. Mooar Brothers (Garza County Deed Record 3:29-32). Fifteen years later, after a legal dispute had been settled over ownership of the Houston and Great Northern Rallway Company land, a number of sections, including Section 57, Block 5, were conveyed to Thomas R. White, Jr., of Union County, New Jersey (Texas. General Land Office 1873b).

White held Section 57 until June 18, 1901, when he sold Sections 57 and 59 to A. 0. Scarborough (Garza County Deed Record 7:112-114). In about 1905-1906, when the assessment on Section 57 increased by ca. 33\%, Scarborough constructed a house at 41KT58; in 1906 he declared Section 57 to be the location of his homestead (Texas. General Land Office 1924).

According to a neighbor (Ford 1987), Scarborough's home was a two-story structure with dormers. Following its destruction, Scarborough sold the property to W. G. Williams in about 1912 and moved to Snyder where he ran a sanitarium. The new owner rebuilt on the site, but his house, which he rented out, burned also (Ford 1987). Today, Section 57 is still owned by Williams' descendants.

Assessment/Recommendations: Site 41KT58 includes the remains of a resident1al complex with cisterns and outbuildings which were used as early as 1905. Over 50\% of the site appears intact; it may contain subsurface deposits. The site has an unknown research potential but is judged to be potentially eligible for listing on the NRHP according to Criterion D. It is recommended that the site be tested to ascertain integrity, that outbullding sites be located and mapped, and that a member of the Williams family be interviewed concerning the history of the site.

\section{$\underline{41 K T 60}$}

Location: Ca. $3.1 \mathrm{~km}$ SSE of confluence of Double Mountain Fork and Grape Creek, and $7.0 \mathrm{~km}$ ENE of confluence of Double Mountain Fork and Rocky Creek. 
Description: Rock art site on vertical sandstone face on bluff below upland margin overlooking Grape Creek; elevation $2150 \mathrm{ft} \mathrm{msl}$, area $50 \mathrm{~m}^{2}$. Several names and sets of initials carved into rock face, most recent with two possibly historic dates. Most inscriptions are faint and eroded. Temporal component is Historic.

Features: Two historic inscriptions. First reads "JF P. STELL HOLL R MAR. 44. 11." First three initials written with common vertical line; date interpreted as March 11, 1944. Other inscription reads "VANIE DUKE 1912." Date is deeply etched but poorly written, so could read 1912, 1913, 1812, or 1813, or be initials; 1912 is most plausible reading. For further information about inscriptions, see Appendix E.

Cultural Materials Observed/Collected: None.

Shovel Test Data: None.

Assesseent/Recommendations: Over $90 \%$ of the site appears intact; it lacks associated subsurface deposits. The site has information yield potential and is judged to be potentially eligible for listing on the NRHP. However, initial field recording has exhausted the site's potential at this time, and no further work is recommended.

\section{$41 \mathrm{KT} 65$}

Location: Ca. $4.1 \mathrm{~km}$ SSE of confluence of Double Mountain Fork and Grape Creek, and $6.9 \mathrm{~km}$ ESE of confluence of Double Mountain Fork and Rocky Creek.

Description: Rock art site in rockshelter eroded from bluff overlooking Grape Creek; elevation $2270 \mathrm{ft} \mathrm{msl}$, area $50 \mathrm{~m}^{2}$. Shelter ca. $10 \mathrm{~m}$ long and $3 \mathrm{~m}$ deep has ca. 2-m-wide bench in front. Floor of shelter is bare sandstone. Four panels of rock art, three aboriginal and one historic, on back wall and roof of shelter. Temporal components are Historic and undefined Prehistoric (see Appendix F for description of prehistoric component).

Features: Two historic inscriptions on panel ca. $1 \mathrm{~m} \mathrm{long}$ and $0.5 \mathrm{~m}$ high. First is ca. $37 \mathrm{~cm}$ long and $10 \mathrm{~cm}$ tall and reads "WWG 1908," with date written ca. half size of initials. Other inscription is ca. $42 \mathrm{~cm}$ long and $20 \mathrm{~cm}$ tall and reads "JHG." This inscription is deeply carved and could be historic. For further information about inscriptIons, see Appendix E.

\section{Cultural Materials Observed/Collected: None.}

Shovel Test Data: One negative shovel test on bench outside shelter found ca. $50 \mathrm{~cm}$ of soil.

Assessment/Recommendations: Over $90 \%$ of the historic inscriptions appear intact; they lack associated subsurface deposits. The historic inscriptions have research potential and are judged to be potentially eligible for listing on the NRHP. However, initial field recording has exhausted the site's potential at this time, and no further work is recommended. 
Location: Ca. $4.9 \mathrm{~km}$ SSE of confluence of Double Mountain Fork and Grape Creek, and $4.4 \mathrm{~km}$ SE of confluence of Double Mountain Fork and Little Grape Creek.

Description: Rock art site on vertical sandstone face on bluff overlooking Grape Creek; elevation 2280-2290 ft $\mathrm{msl}$, area $1.4 \mathrm{~m}^{2}$. Three historic inscriptions carved into sandstone, one with historic date. Two others have no dates but are written in historic lettering style. Rock face damaged by spalling, and one inscription partially missing. Temporal component is Historic.

Features: Three inscriptions: one ca. $85 \mathrm{~cm}$ long and $15 \mathrm{~cm}$ tall and reads "HG....12 1910;" lower half of inscription spalled off, and central letters too eroded to read. Other two inscriptions read "JESP" (45 cm long and $15 \mathrm{~cm}$ high) and "H" (12 cm long and 15 $\mathrm{cm}$ high) but may be recent. For further information about inscriptions, see Appendix E.

Cultural Materials Observed/Collected: None.

Shovel Test Data: None.

Assessment/Recommendations: Over 90\% of the site appears intact; it lacks associated subsurface deposits. The site has research potential and is judged to be potentially eligible for listing on the NRHP. However, initial fleld recording has exhausted the site's potential at this time, and no further work is recommended.

\section{$41 \mathrm{KT} 73$}

Location: Ca. $6.7 \mathrm{~km}$ SSW of confluence of Double Mountain Fork and South Sage Creek, and $6.6 \mathrm{~km}$ SE of confluence of Double Mountain Fork and Cat Hollow.

Description: Rock art site in rockshelter eroded from bluff overlooking Grape Creek; elevation $2250 \mathrm{ft} \mathrm{msl}$, area $7.5 \mathrm{~m}^{2}$. Shelter is ca. $3 \mathrm{~m}$ wide and $2.5 \mathrm{~m}$ deep; floor was probed but no cultural deposits found. Single historic inscription carved into back wall of shelter. Temporal component is Historic.

Features: Single historic inscription ca. $95 \mathrm{~cm}$ long and $15 \mathrm{~cm}$ tall reads "P. E. Ware 1931." For further information about this inscription, see Appendix E.

Cultural Materials Observed/Collected: None.

Shovel Test Data: One shovel probe was negative.

Assessment/Recommendations: Over $90 \%$ of the site appears intact; it lacks associated subsurface deposits. The site has research potential and is judged to be potentially eligible for listing on the NRHP. However, initial field recording has exhausted the site's potential at this time, and no further work is recommended. 
Location: Ca. $7.0 \mathrm{~km}$ SSW of confluence of Double Mountain Fork and South Sage Creek, and $4.7 \mathrm{~km} \mathrm{SE}$ of confluence of Double Mountain Fork and Little Grape Creek.

Description: Rock art site on large vertical rock face overlooking confluence of Grape Creek and small side drainage; elevation 2240-2260 ft msl, area $70 \mathrm{~m}^{2}$. Rock face ca. $10 \mathrm{~m}$ long and $7 \mathrm{~m} \mathrm{high} \mathrm{has} \mathrm{six} \mathrm{panels} \mathrm{of} \mathrm{inscriptions;} \mathrm{five} \mathrm{appear} \mathrm{to} \mathrm{be} \mathrm{historic} \mathrm{by} \mathrm{virtue}$ of lettering style, and one has historic date. Temporal component is Historic.

Features: Dated inscription is ca. $125 \mathrm{~cm}$ long and $75 \mathrm{~cm}$ tall and reads "C. S. P. AUGUST 24.1907." "9" written backwards, and inscription damaged by bullet holes. Other inscriptions are "D.A.S. ... A" $(56 \times 10 \mathrm{~cm})$, "F. K. S." $(24 \times 9 \mathrm{~cm})$, "JIM E." and "BTS" (64x19 $\mathrm{cm})$, and "D S" $(14 \times 9 \mathrm{~cm})$ surrounded by rectangular outline $(22 \times 15 \mathrm{~cm})$. Some isolated letters also occur, including " $R$ " written in ornate block print. Some of the inscriptions are probably recent. For further information about inscriptions, see Appendix E.

Cultural Materials Observed/Collected: None.

Shovel Test Data: None.

Assessment/Recommendations: Over 90\% of the site appears intact; it lacks associated subsurface deposits. The site has research potential and is judged to be potentially eligible for listing on the NRHP. However, initial field recording has exhausted the site's potential at this time, and no further work is recommended.

\section{$\underline{41 \mathrm{KT} 84}$}

Location: Ca. $0.2 \mathrm{~km}$ ESE of northernmost intersection of Garza/Kent county line and Grape Creek, and $2.9 \mathrm{~km}$ NNE of intersection of Garza/Kent county line and Garza/Kent/Scurry county line.

Description: Line camp site on two alluvial terraces overlooking Grape Creek near base of small erosional remnant mesa; elevation 2260-2280 ft msl, area $2500 \mathrm{~m}^{2}$. Historic dugout complex on earlier prehistoric campsite, including dugout, stone outbuilding, and associated artifact scatter. Dugout is on lower terrace above creek, while outbuilding is at base of mesa ca. 100 ft west of dugout. Slightly disturbed by erosion, with no evidence of human disturbances. Very early dugout occupied by OS cowboys as line camp. Temporal components are Historic and undefined Prehistoric (see Appendix $F$ for description of prehistoric component).

Features: Two features: dugout and outbuilding. Dugout depression ca. $13 \mathrm{ft}$ in diameter has pile of sandstone slabs ca. $3 \mathrm{ft}$ long and $10 \mathrm{ft}$ wide next to it. Artifacts scattered in and around rock pile and downslope toward creek. Stone outbuilding ca. $18 \mathrm{ft}$ long and $9.5 \mathrm{ft}$ wide represented by sandstone slabs and fragments forming low walls of rectangular structure on bedrock exposure. Soil deposits in corner nearest mesa. 
Cultural Materials Observed/Collected: Rim fragment of tooled-lip aqua-colored glass bottle or jar, fragment of aqua-colored glass panel bottle with "C \& CO" embossed on base, plain whiteware plate fragment with maker's mark on base, brass shell case, and two cast iron fragments (stove parts or skillet fragments). One item collected (see Appendices A and $\mathrm{B})$.

Shovel Test Data: None.

Site History: Site $41 \mathrm{KT} 84$ is located in Section 60 , Block 5, a tract comprised of 49 acres In Garza County and 591 acres in Kent County. On June 19, 1882, J. Wright Mooar, on behalf of $\mathrm{H}$. T. Cornelius, his partner in the cattle business, made application to the General Land Office to purchase Section 60 , and two weeks later, he made the first payment (Texas. General Land Office 1900a). Cornelius held the section, along with Sections 58 and 56 to the north, until December 14, 1886, when he sold them to A. J. Long, a cattleman from Nolan County. Long, with his brother, F. M., then leased additional sections in Blocks 5 and 6 which they used for grazing purposes (Kent County Deed Record 1:309-310; Deed Record $\underline{5}: 395-396)$.

On June 7, 1901, the Longs, now residents of Tarrant County, sold a total of 26,411 acres in Kent and Garza counties, including Section 60, Block 5, on which $41 \mathrm{KT} 84$ is located, to a partnership consisting of W. E. Connell of Tarrant County, John Scharbauer of Tarrant County, and E. W. Clark of Scurry County (Kent County Deed Record 8:199-202). The new partnership then applied for a patent from the General Land Office (Texas. General Land Office 1900a).

After 1916, Section 60 was owned by a number of individuals, including W. B. Stanfield (ca. 1917-1930), Mrs. Willie Thompson (ca. 1931), H. G. Towell (ca. 1932-1934), G. G. Yeatts (ca. 1935-1941), W. H. Mason (ca. 1942-1943), T. A. Upshaw (ca. 1944), W. G. Williams or his estate (ca. 1945-1963), and Mrs. Alice Clark or her estate (1964-present).

Assessment/Recommendations: Site 41KT84, which seems to be the earliest Anglo site occupied over a long period of time in the project area, has been identified by an informant as one of two camps maintained by the Long Brothers (Boren 1978, 1987). The fact that the Longs bought out J. Wright Mooar and H. T. Cornelius suggests that the site may date to at least 1882 when Cornelius bought Section 6, Block 5, from the General Land Office. According to the same informant, the dugout used by the Longs on Grape Creek was occupied by numerous cowboys employed on the Longs' OS Ranch. Among these were James Minus Boren, Ed Scott, Will Williams, and O. B. Kelly.

Site 41KT84 is associated with the earliest major cattle companies in the project area. Over $75 \%$ of the historic component appears intact; it contains structural remains and subsurface deposits. The site has an excellent research potential and is judged to be potentially eligible for listing on the NRHP according to Criteria A, B, and D. Because this site is located outside the project area, further work is not recommended at this time. However, further research could confirm the site's identity and testing could determine the size of the dugout and size and function of the outbuilding. An accurate map and a controlled surface collection could assist with the identification of the age and function of the site. Finally, a comparison of $41 \mathrm{KT} 84$ with other, later dugout sites occupied by the same cowboys in the project area, and with later, postrailroad historic sites would be helpful. 


\section{REFERENCES CITED}

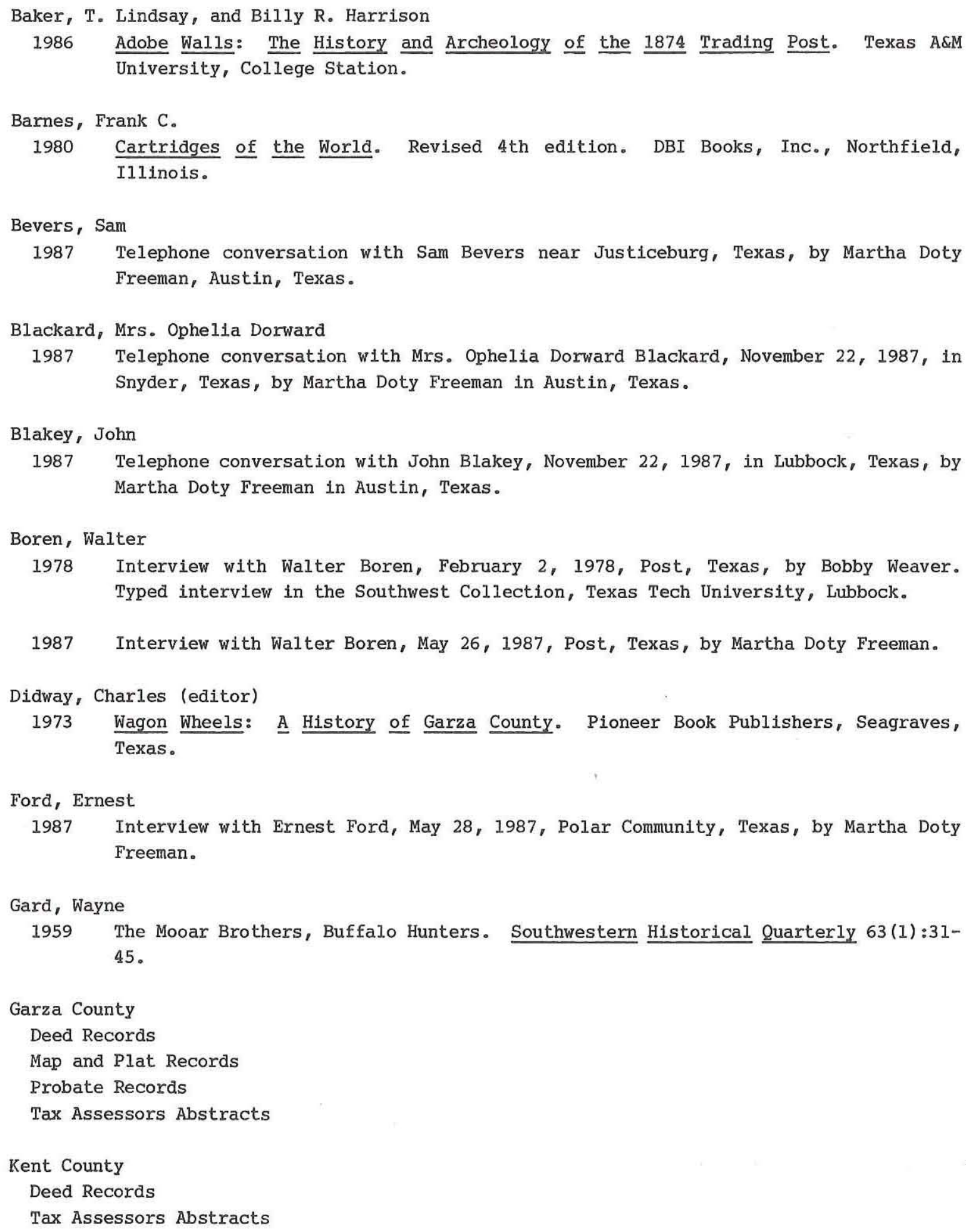


McCrary, Giles

1970 Connell Gained Fame As Banker, Rancher. In The Coming West. September $19,1970$. Ranch Headquarters Association, Snyder, Texas.

Nance, Mrs. Pearl

1987 Interview with Mrs. Pearl Nance, May 27, 1987, Post, Texas, by Martha Doty Freeman.

Post Dispatch, The

Riggs, Aaron D., Jr.

1965 Petroglyphs of Garza County, Texas. Transactions of the First Regional Archeological Symposium for Southeastern New Mexico and Western Texas:9-14.

1966 The Reed Shelter: A Petroglyph Site in Garza County, Texas. Transactions of the Second Regional Archeological Symposium for Southeastern New Mexico and Western Texas: 44-58.

Rodgers, Mrs. Irene Van Leer

1969 Interview with Mrs. Irene Van Leer Rodgers, May 30, 1969, Lubbock, Texas, by David B. Gracy, III. Taped interview in the Southwest Collection, Texas Tech University, Lubbock.

Texas. Comptroller of Public Accounts

1886- Assessment Roll of Property in Garza County, Owned by Residents and Rendered for

1894 Taxation by the Owners or Agents Thereof. Microfilm in the collections of the Texas State Library and Archives, Austin.

Texas. General Land Office

1873a Fannin Scrip 6069. Kent County Abstract 121, Garza County Abstract 811. H\&GN Railway Company Certificate No. 6/1028. Patented December 27, 1873.

1873b Fannin Scrip 6006. Abstract 58. H\&GN Railway Company. Patented to original, December 27, 1873.

1873c Fannin Scrip 6088. Abstract 70. H\&GN Rallway Company. Patented to original, December 27, 1873.

1873d Fannin Scrip 6094. Abstract 76. H\&GN Railway Company Certificate No. 6/1053. Patented to Railroad, December 27, 1873.

1873e Fannin Scrip 6187. Abstract 145. H\&GN Railway Company Certificate No. 12/2409. Patented to original, December 9, 1873.

$1873 f$ Fannin Scrip 6191. Abstract 149. H\&GN Railway Company Certificate No. $12 / 2413$. Patented to original, December 27, 1873.

1900a Garza County. File 9892. Garza County Abstract 2045; Kent County Abstract 467. H\&GN Railway Company Certificate No. 6/1024. Patented July 2, 1900. 
1900b Kent County. File 9891. Kent County Abstract 466; Garza County Abștract 802. H\&GN Railway Company Certificate No. 6/1027. Patented July 2, 1900.

1914 Garza County. File 60432. Abstract 932. H\&GN Railway Company Certificate No. 6/1040. Patented October 1, 1914.

1919a Garza County. File 58826. Abstract 927. H\&GN Railway Company Certificate No. 12/2414. Patented July 21, 1919.

1919b Garza County. File 58972. Abstract 831. H\&GN Railway Company Certificate No. 6/1056. Patented March 8, 1919.

1924 Garza County. File 59193. Abstract 942. H\&GN Railway Company Certificate No. 6/1032. Patented to S. C. Porter, assignee, February 6, 1924.

1934 Garza County. File 59209. Abstract 948. H\&GN Railway Company Certificate No. 6/1047. Patented to Walter Roy, December 10, 1934.

1935 Garza County. File 59210. Abstract 946. H\&GN Railway Company Certificate No. 6/1052. Patented to Walter Roy, February 28, 1935.

1936 Garza County. File 58825. Abstract 928. H\&GN Railway Company Certificate No. 12/2415. Patented to T. E. Payne, assignee, November 14, 1936.

1939a Garza County. File 59126. Abstract 897. H\&GN Railway Company Certificate No. 12/2408. Patented to Jeff D. Justice, assignee, August 16, 1939.

1939b Garza County. File 59132. Abstract 903. H\&GN Railway Company Certificate No. 12/2412. Patented to Jeff Justice, August 16, 1939.

U.S. Bureau of the Census

1900 Garza County

Ward, John

1987 Interview with John Ward, May 27, 1987, Justiceburg, Texas, by Martha Doty Freeman.

Women's Division of Post Chamber of Commerce (compiler and editor)

n.d. Foot Prints: $\underline{\text { History }}$ of Garza County and Its People. Taylor Publishing Company, n.p. 

3. +4 